\title{
工業化學雜誌附 錄
}

\author{
第 7 號
}

\author{
昭和 7 年度
}

本邦工業化學研究業蹟概要

法阅 工 業 化 學 會 


\section{序}

1. 此小册子は是に本會にて募集したる工業化學會基金の利子 によりて刊行せらるなるのである。

2. 此小册子は工業化學雜誌の附錄として 1 ケ年約 3 回不定期 几利行せらる。

3. 刊行の目的は工業化學に關する漸新且明確なる知識の普及 を圖るにある。

4. 此附錄は無料で工業化學會々員に配布する。

昭 和 8 年 3 月

留鱼工業 化 學 會 


\section{目次}

1. 化學工學及化學工業用機械

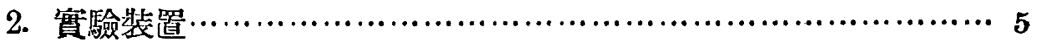

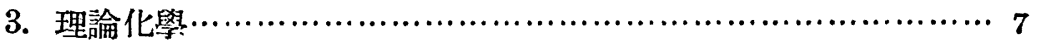

4. 無機化學……………………………………………………… 33

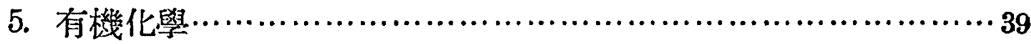

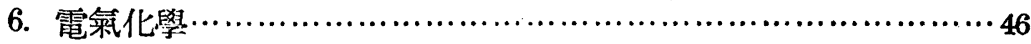

7. 酸, アルカリ及肥料…………………………………………. 56

8. 鑛物，治金及金工…………………………………………6. 62

9. 陶磁器，ガラス及耐火材………………………………........

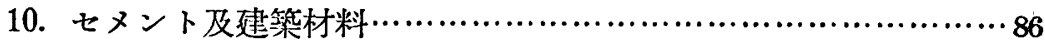

11. 石油及アスファルト………………………………….......... 99

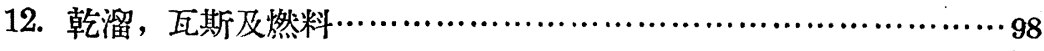

13. 染料, 染色及紡織化學…………………………………. 100

14. 油脂, 蠟及石襝

15. 精油, 香料及化性品…………………………………........ 113

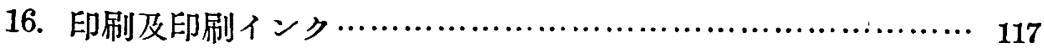

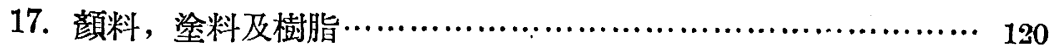

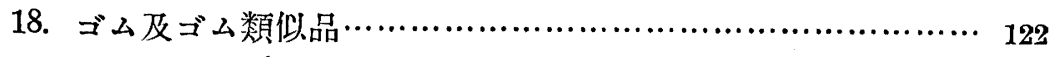

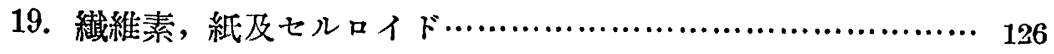

20. 䌅類, 澱粉及其他の炭水化物…………………………........ 141

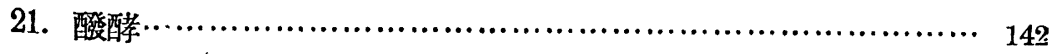

22. 製革及膠類……………………………………….......... 152 


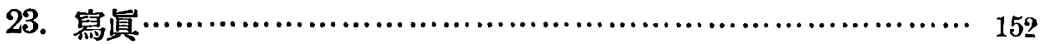

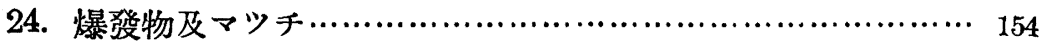

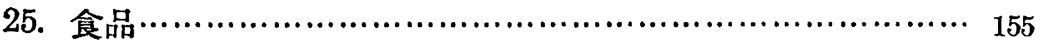

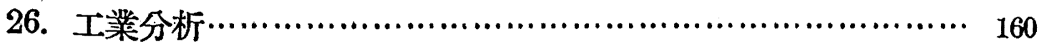




\section{原報所載雜誌, 報告名及其略字}

（咯號を用ひしもの小みを揭ぐ）

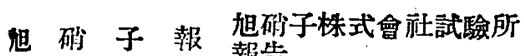

鞍山 践 鞍山鐵鏡會誌

印刷 印刷焳誌

印時報 印刷時報

印タ1ム印刷タイムス

愐

化 日本冨生化學會誌

㣟 生 試 報 耐生試驗所営報

大工試 大阪工業試驗所報告

大工研 大阪市立工業研究所報

大原晨研報大原農業研究所報告

科

工 科學と工業

化工 時 郝 化學工業時報

化 工 資 化學工業資料

海 燃 海軍然料廠研究献告

神工 試 帖奈川懸工業試驗場報

學 政 協 郝 日本學沺協會報告

岩石 岩石磁物碚床學

頑症インキ敦料塗料印刷インキ

火 兵 火兵學會誌

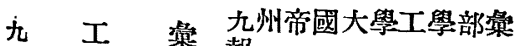

報

九 鏣 九州鈸山學會誌

京 理 紀 京都帝國大學理學部紀

京 工 紀 京都帝國大學工學部紀

京農 紀 京都帝國大學農學部紀

金屬金厭の研究

粗試 絹業試驗所㘧告

建筑 趣筑雑誌

航 空 研 報 東京帝國大學航空研究
笽

採

上海 科 砛

酄

釀

数

水

水

住 友

慗

慗 鐡

繊

專

仙

石

早應

造

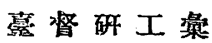

管督研工報

地

朝

朝

鐵

㲣

管

管

箅

電

霆

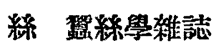

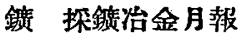

上海自然科學研究所偊

報

試 酩喈試驗所報告

造 亚造學雜誌

物 日本數學物理學會記事

曜 水曜會誌

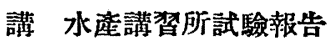

研 住友伸銅鐝管株式會社 研究媇告

鐵 製鐵研究

研 製鐵所研究所研究報告

工 繊維素工業

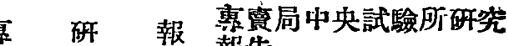
報告

高 工 紀 仙冨高等工業學校紀项

油 石油時報

化 早稻田應用化學會報

幣 喈幣局研究報告

堂㩐總督府中央研究所 工类部呆報

壹灣總督府中央研究所

工業部報告

質 地質學雜誌

解 鐻 朝鮮鍍業會誌

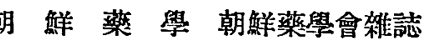

銅 鐵之銓

業 資 鐵道省業䭻研究資料

工 萑 帝國工藝

氮 試 報 電氣試驗所政究報告

試 調 電氣試驗所調查報告

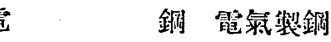

訴 電氣䛙諭 
需

電

東 I 試 東京工業陚驗所報告

東 工 紀 榻京帝國大學工學部紀

東工 學 報 東京工業大學學報

東

東 北 工 報

東 北 理 報

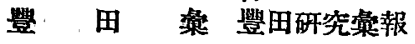

土 瀷 肥 料 土玫肥料學誰誌

队

印离閔印刷局研究所調查

南滿試 南滿洲鐵道株式會岻中

南、倆試矢試驗所報告

日 化 日本化學會誌

日 化 工 日本化學工業新聞

日 化 總 日本化學總覽

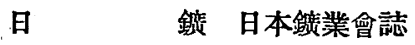

然協 燃料協會誌

燃研 報燃料研究所報告

農化 日本農藝化學會誌

费

農 試 唻 農事試驗場巢報

研農學研究

廣 理 紀 廣島文理科大學紀要

物 理 化 學 物理化學の進步

北 工 試 北海道工業試驗場報告

北海 醫 北海道醫學雜誌

本誖 工業化學誰誌
ポルトランド日本ポルトランドセメ セメント技報 ント技㼛協會報告

マ ツ ダ マツダ研究時報

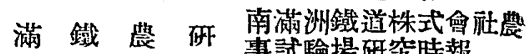

坡事試驗場研究時報

明 專 報 明治專門學校學郝

藥

學 藥學獭誌

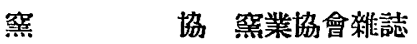

筈

接 鎔接協會堎

理 研 報 理化學研究所谋報

旅工紀 旅順工科大學紀要

旅 工 梏 旅順工科大學架報

林

學 林學會噍誌

Biochem.

The Journal of Biochemistry

Bull. C. S. .J.

Bulletin of the Chemical Society of Japan

J. J. $P$.

Japanese Journal of Physics

P. I. $A$.

Proceedings of the Imperial Academy

Phot. Ind.

Photographische Industrie

Sc. $P$.

Scientific Papers of the Institute of Physical and Chemical Research

S. Sc. $P$.

Supplement of Scientific Papers of the Institute of Physical and Chemical Research 


\section{昭 和 7 年 \\ 本邦工業化學研究業蹟概要 \\ 編 輯 委 員 會}

\section{1. 化學工學及化學工業用機械}

本部門に屬する研究は從來殆ど擧げ來るもの無き狀態なりしが本年は俄 かに數個の報告あるを見たるは斯界のため聊か意を强くするものなり。

材料に關する研究 山本洋一氏（理研報 11, 834）は監酸に依る鼠鑄鐵 の腐蝕後の表面の空氣中に於ける發熱現象及び鼠鑄鐵の鹽酸に化る腐蝕に 及ぼす銅の添加の影響に就て研究し次の如き結果を得たり。特に濃度の大 なる監酸は別として約 $20 \% \mathrm{HCl}$ までの濃度の監酸に依つて鼠鑄鐵が腐蝕 せらる」場合にはかなりに剝脫し難き表皮を形成し, 之を液外に取り出し 空氣中に放置すれば其の腐蝕の程度に應じて發熱現象を呈す。此の發熱現 象は腐蝕後に殘存する黑鉛及炭化鐵より成る多孔質表皮の酸化に依る 80 と著者は解釋せり。

又同氏 (理研報 11, 1157)结硝酸に依る鼠鑄鐵の腐蝕の場合, 硝酸溶液 中の試料の酸化に件ふ溫度上昇と腐蝕後の試料表面の宾氣中に於ける發熱 現象を研究し次の結論に達せり。硝酸の鐵に對する作用には酸としての溶

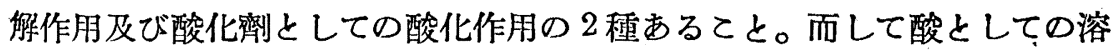
解作用は鐵の腐蝕減量の主因をなすとと。又酸化劑としての作用は酸化皮 膜を形成して腐蝕を抑制するものなるてと。此の 2 種の作用は硝酸の濃度 に支配され，濃度高き程酸化作用大となり終に全く腐飿減量を示さざるに 
至ること。又鼠鑄鐵を硝酸に浸したる場合の發熱は酸化作用に依るるのに して腐蝕量とな無關係なるてと。硝酸の濃度 $2.9 \%$ 以下の場合は主として 溶解作用起り之を宾氣中に放置する時發熱することは前記盬酸の場合と全 く同樣に說明出らる〉とと。硝酸濃度 $29 \%$ 以上の時は酸化作用のため不 溶性酸化皮膜を生じ, 所謂受働態となること。且つ此場合は液中に於て酸 化作用完全に行はる」結果, 空氯中に放置するも發熱現象を呈せざること。 佾同氏 (理研報 11, 1215)は硫酸に依る鼠鑄鐵の腐搶後の表面の空氣中 に於ける發熱現象に就て研究し，監酸の場合と同㥞の說明を與へたり。但 し此場合，硫酸の濃度特に大なる場合は液中に於て僅かに發熱の傾向ある を認めたり。

松井元太郎, 加藤弘人兩氏（本誌 35，780）は鉛板の物理的並に機械的 試驗を行ひ，比重，硬度，抗張力及延伸率を测定し更に鉛板の硬度測定に 適應する試驗器を考案せり。又网氏等は鉛板の燒戻が抗張力, 延伸率及び 硬度に對する影響を試驗し，更に各種鉛板の融點を测定し, 又 Flash test を行へり。

更に兩氏（本誌 35，784）は硫酸に依る鉛板の腐蝕試驗を行ひ，腐蝕度 の異常に大なる點あるを認め之を組成成分の不均一なる䈏所と推定せり。 叉含硝硫酸の腐蝕作用を試驗し, 更に $100^{\circ} \mathrm{C}$ に燒危せるるのが物理的 性質に變異あると同時に腐蝕度る垻進するてとを認め，アンチモン合金は 窒素酸化物に作用を蒙るとと大なること及び Flash test と一般腐蝕作用 とは件はざるととを指摘せり。

氣體の流れに關する研究 安積宏氏（理研報 11, 1103）は氣䯣混合物の 毛細管流出に關する研究を開始し，氣體混合物の粘度に就て碡告せり。同 氏は流出法を利用せる粘度計に依りて次の 6 種の氣䚛及び 7 種の氣體混合 物の粘度を $20 \sim 100^{\circ} \mathrm{C}$ の範園に亘つて實测せり。水素, メタン,ェタン, 
プロパン, アセチレン, プロピレン, 水素ヤメタン, 水素ヤアセチレン, 水素十エタン, 水素十プロピレン, メタントアセチレン, アセチレントプ ロピレン, プロピレン+プロパン。以上混合物中, 水素十メタンは水素約 $20 \%$ 附近に文水素十アセチレン，水素十エタン，水素十プロピレンは各水 素の約 70〜80\% 附近に極大點を有する粘度曲線を得たれども其他の 3 種 は極大值なくプロパンープロピレンは殆ど直線的に變化するを認めたり。 又同氏は混合物の粘度に關する一般式を吟味せり。

岡本絪象氏（九工彙 7，80）はオリフィスを通して流る」空氣量を岑酸ガ ス混入に依る方法に依つて测定せり。

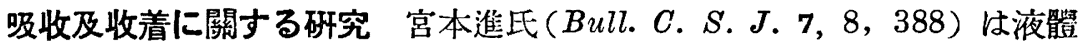
中に瓦斯の溶解する速度に就て研究し, 從來の靜止境曆說の代りに瓦斯分 子の衝突を基礎と过る新說を提出し, 更に分配率を運動學的方面より誘導 せり。八田四郎次氏（本誌 35, 1389） は液體に依る瓦斯の吸收速度の研 究を續行し，化學反應に依る瓦斯吸收の理論的考究を行へり。郎ち同氏は Lewis 及 Whitman 兩氏の二重膜說を引用し，八田氏の概念を加へて吸收 速度つ式を提出せり。又同氏（本誌 35, 1397）は炭酸瓦斯の炭酸カリウム 溶液に依る吸收に就て硎究したり。

鮫島實三郎氏（日化 53，1129）は固體が蒸氣を收着する速度に就て研 笁し，同氏が先に提出したる $x=d \log t+K$ なる式は純粹なる氣體が一定 㰮の下に於て多孔質固體に吸はる」際の速度を示す式なるが，之を空氣と

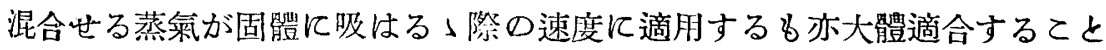
索認めたり。

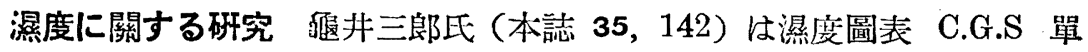

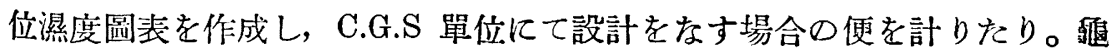
井三郎, 後原保网上（本誌 35,147 ) は化學工等用諸原料の平衡水分の測 
定を行へり。郎ち石簽 3 種, 粘土 4 䅜, 木材 3 種及びパルプに就て其の 平衡水分を測定し，各材料の平衡水分對關係濕度曲線は S 字师をなすとと 及び各溫度に於ける吸濕等溫線は相一致せずして或與へられたる關係溫度 に於ける吸濕作用は溫度が高まれば一般に秒減少するてとを認めたり。

爐の作業 野田稻吉, 小山田茂, 本城蔚氏等 (本誌 35, 332) は本邦に 於ける石灰燒成爐の作業江就て研究し, 石灰爐各部の溫度を測定し且つ瓦 斯分析を行ひ燒成工程中に於ける瓦斯速度を示し，爐の非效率等に就て考 察を行へり。

蒸墢罐 宮崎好文氏（本誌 35，110）は買空蒸發罐に就て其の利點, 其 の型式, 蒸發能力, 蒸發能率, 蒸溜水製造用三重效用蒸發巏の運轉結果等 を論ぜり。

遠心分離機 宮崎好文氏（本誌 35，114）は遠心分離機に就て論じ，特

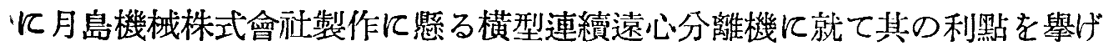
たり。

其他 橫山武一比（本誌 35，842）懽和肥料株式會社川崎工場に就て と題して工場設備，化學機㭜等に就て詳論せり。該工場の化學機械類が悉 く本邦國產品なることは化學機械工業に於て聊か意を强くするものありと

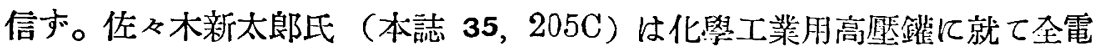
弧鎔接製のものを論述せり。內田俊一氏（本誌 35，102）は化場工場の合 理的設計と題して工場の製座能力の 問題等に就て論じたり。友田冝孝氏 （本誌 35,107 ）は化學工學上工粱化學の提携と題して化學機械用材料, 粉碎機, 蒸發器等に於て工業化學的立場上り研究を進むべさ點多くあるて とを諭ぜり。 


\section{2. 實驗裝 置}

溫度計 俈心木達治郎, 服部邦男, 楯林次氏等( 航空研報 90, 61) は蒸 氣壓を利用する溫度計の導き管及び指示器の溫度が其の指度に及ぼす影響 飞就て研究せり。神原周, 松井元太郎兩氏（本誌 35，453）は白金抵抗寒 暖計に關する研究を續行し，低溫度定點测定に關する報告をなせり。 郎ち白金抵抗寒暖計を低溫度测定に使用せんとし $0^{\circ} \mathrm{C}$ 以下 $-190^{\circ} \mathrm{C}$ の間 に $R_{t}=R_{0}\left[1+A_{t}+B_{t}{ }^{2}+C(t-100) t^{3}\right]$ なる式を探用し是に必要なる恒數を 沈定せり。.

溫度調節器 潹口信男氏 (日化 53,319) は恒溫槽, 恒壓器等の電氣調 節器に於ける水銀と白金又は鐵との接觸面の火花除去に就て研究し, 火花 除去のために県空管を用ふる利谷を論究し，供用さるべき繼電器の感度は 普通級のものにて充分足る事を明かにせり。又同氏(日化 53，377)は恒温 槽の恒溫調節の一方法に就て研究し, 恒溫槽の示す溫度變化は熱源の僬れ に因るものと溫度調節器のリレー動作に因るるのとの和, 郎ち $\Delta T=\Delta^{\prime} T$ $+\Delta^{\prime \prime} T$ にして，溫度上景及下降速度は大なる程溫度變化 $\Delta T$ に及活す影 響は良好なるも電源の電厴變動及び室溫の變化に支配せられ, 或程度以下 になすことは不能なるととを㪕じ，溫度調節器のリレー動作と恒溫調簛の 直接原因をる加熱冷却動作とを同期をらしめんため，槽の液の溫度と異る 溫度の液を加熱或は冷却原因に用ひ熱源に因る溫度變化 $\Delta^{\prime \prime} T$ を除去せり。 又同氏は室溫以上 $80^{\circ} \mathrm{C}$ まで及び室溫以下 $-10^{\circ} \mathrm{C}$ までの任意の恒溫を調 整し得る槽を構成吖り。更に同氏（日化 53，441）は液體膨脹型溫度調節 器の感度に就て研究し, 溫度調節器の調節動作の根本原因たる液嘪の膨脹 收縮は他の一般規則と同樣に熱の出入に依る周期變化なるを以て直線的單 方向的熱䔟動と其の趣を異にし交番熱流をるを以て其の感度を論ずる上に 
又此等の理論を應用せざるべからざるととを指摘し, 溫度調節器の壁の嬮 さ等に就て諭ぜられたり。

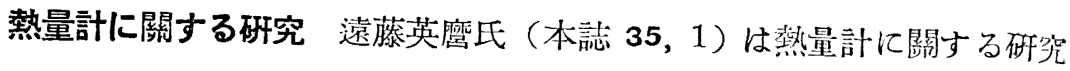

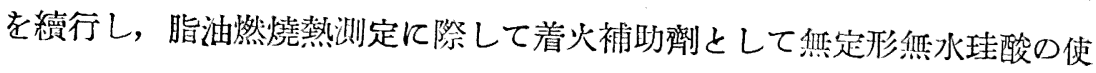
用可否を試驗して其の不可なるてとを指摘出り。又同氏 (本誌 35，5）は ゴムの燃燒熱測定に就て研㠰せり。

融點測定装置 松井元太郎, 加藤弘人网氏 (本誌 35,458 ) は米國デン= ス氏新案融點測定器の缺點不供を考虑し同樣目的の改良裝置老呈出世り。 膨脹計に關する䂰究 下村明氏 (然協 11, 184, 794) は加熱に依る石岑

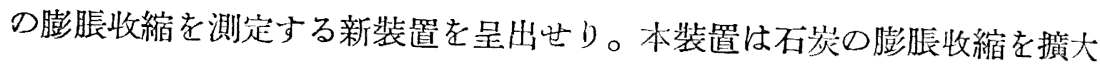
して自記する裝置なり。松壮元太郎, 神原周兩氏（本誌 35，788）は膨脹 計に依る含水監類轉移點の精密測定を行へり。

高溫天秤 田丸節郎, 監見賢吾, 安達正明氏等 (日化 53, 329, 647) は 任意の高溫度に於て眞空又は任意の瓦斯中に於ける重量の變化を精密に且 つ容易に测定し得る新型高溫㓂空天科に就て說明し，监機化合物の解離壓 の新测定を行へり。

電壓滴定裝置 箱守新一郎, 岡好良兩氏 (日化 53, 604) は 2 球式眞空 管滴定装置を設計し各條件を詳細に吟味し更に光電管を利用せる自働ビュ レットを考穼せり。

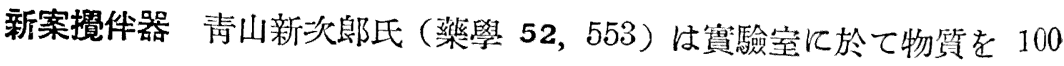
${ }^{\circ} \mathrm{C}$ 附近の沸點を有する溶劑と共に煮沸しつ」反應せしむる際攪拌の必要 する時, 從來の硝子製鞘を具へたる攪䢁器は用ふる時溶卿が䩗內に溜入し て不便なるを以て鞘の下部に冷却裝置を具へをるものを更に簢便なるるの となせり。

連續液體抽出器 緒方章, 佐藤四十二兩氏（藥學 52,671）は男尿中よ 
り男性ホルモンを抽出する日的のために 1 種の連續液體抽出器を案出せ b。

防濕力測定器 青野武雄氏（本誌 35, 1093）は包裝用紙の防濕力を簡 易に测定する裝置案出せり。

風篩器 宮澤清氏 (本誌 35, 1382) は粉末程度芸驗用の風篩器に就て行 へる實驗結果を報告せり。

\section{3. 理 論 化 學}

物理學的研究 䟢生武雄氏（日化 53，504）はへキシルヘプチルオクチ ルアルコールの電波異常分散並に吸收を研究して波長 $50,7.18,3.08 \mathrm{~m}$ に 對して電波の買常分散吸收を見出しその範圍と波長との關係を示したり。 同氏 (同誌 53，657) は更にアミルアルコール，アミルアルコールーヘキ サン系, アミルアルコールーベンゾール系の 3 系統に就て電波の異常吸收 分散を -60 〜 $60^{\circ} \mathrm{C}$ 範圍に於て種々なる組成に對して研究したり。水 島三一郎氏（日化 53，512）は分子の衝突に閵する波動力學に就て考察し 衝突せる分子の散亂狀態及び此際の交換效果, 分子衝突斗徑と溫度との關 係を論じたり。涤原健一氏（Sc. P. 18，223，315）は單結晶による陰極線 の廻折を研究し方解石, 岩監, 閃亞鉛鑛, 雲母に就て實驗を行ひ結晶內部 の平均冈部ポテンシャルを見出したり。飯盛里安, 岩瀨榮一兩氏(日化 53, 77 ）は䖝石凹超感光と發光變移律を研究し數多の法則を發見したり。飯盛 里安氏 (理研報 11，1009）はトリウム B の指示放射能に凿する復光係數 を求めたり。

山口太三郎氏（数物 III，14，1）は陰極線の反射による結晶の內部ポテ ンシ +ルを岩籃, 石高, 珪酸監, 方解石に就て決定し, 西久光氏(数物 III, 14，214）はジルコンの䖝光現象に就て考察したり。武藤俊之助氏 $(S c . P$. 
18，249）は $\gamma$ 線に對する $\mathrm{L}_{\mathrm{II}}$ 及 $\mathrm{L}_{\mathrm{III}}$ 電子の光電效果を論じ, 岩瀨榮一 氏（理研報 11，910）は螢石の爇發光と光發光を研究して兩者は略平行性 老有するを見出し撥光と溫度の關係を探究せり。伊藤集愑氏（マツダ 7, 87 ) は天然水晶の燐光と着色を X 線にて研究して發光狀況不純物の影響 認めたり。三枝彥雄, 中村貴義兩氏（東北理報 21，411）け石英の透電 晅數老決定し, 飯盛里安氏（理研報 11, 1137）は加奈陀ウイルバーフォー ス產黑螢石の放射性を研究して之をウラニナイトの存在に歸し，且黑䖝石 破碎の際弗素を墢生するととを見出し其存在狀況を推定したり。不破橘三 氏（マツダ 7，19）は硝子の成分に上る紫外線放射の相違を研究し, 原田 氏（マツダ 7, 11）は眞空管のプレートに使用せらるるニッケル，モリブ デンの熱輻射を研究したり。拔山大三，小林厚兩氏（航空研報 7, No. 82) は水・監化アムモニウムの雲中老通る光の通過率を研究せり。東健一氏 （理研報 11, 729）はアミルアルコール, ベンチルアルコール，樟腦, 龍 腦, チオフ $ン$ チ ニトロソナフトールの双極子能率を測定し, 竹內時男氏 （本誌 35，217）は新物質觀と化合の問題に關して講述せり。

磁氣 木戶清氏（東北理報 21，149）はアルカリ及アルカリ土金屬のハ ロ ゙ン化物, 硝酸監, 水酸化物, 炭酸鹽, 硫酸監, 醋酸鹽及び鈸酸, 醋酸の 反磁氣係數を測定し反磁氣係數の加成律文假定してイオンの磁氣係數を算 出したり。而してその值はイオン中の電子の數に比例するを示せり。同氏 (同誌 21, 288) は更に $\mathrm{Cu}^{+}, \mathrm{Ag}^{+}, \mathrm{Au}^{+}, \mathrm{Zn}^{++}, \mathrm{Cd}^{++}, \mathrm{Hg}^{++}, \mathrm{Hg}_{2}^{++}$の反 磁氣係數を同樣にして求めたり。同氏（同誌 21，385）は叉二元混合溶液 の磁氣係數を测定し, 水一エチルアルコール, 水一メチルアルコール, 水-ア セトン, 水一蜮酸, ベンゾールーエチルアルコール, ベンゾールーアセトン, 四

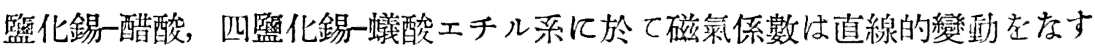
を示したり。增山義雄氏（東北理報 21,394）は鐵・コバルト合金の磁氣 
歪を研究して縱橫の長さの相違を示しその留積變化との關係を求め, 試料 の成分と變化よの間に最大値あるを見出したり。松山芳治氏 (理研報 11, 957)は合金の時效硬化に及济す磁氣處理の影響を研究してその影響する所 少なしと斷定せり。

スペクトル 村川契氏 $(S c . P .17,299 ; 18,97,177,299)$ は水銀スペ クトルの微細構浩に就て研究を行ひ, 黃色部, 紫外部に於ける水銀スペク トルを研究し同位元素のスペクトルに就ては核能率の異る事を示し最後に 短波長に於ける水銀スペクトル微細構造研究者の一覽を附せり。同氏 (Sc. $P .18,191,245)$ は叉鉛スペクトルに就き微細情造を研究し,水銀同位元素 の核能率を決定して各同位元素の微細構造を說明し更に新同位元素 $\mathrm{Pb}_{210}$ の存在を證明し, 更に(同誌 18，304）バリウムの孤光スペクトル及び閃光 スペクトルの微細構造をも研仇して同位元素の核能率を決定せり。木村正 路, 內时洋一兩氏（Sc.P. 18，109，119）はナトリウム蒸氣の紫外部吸收 帶及び黃赤帶スペクトルの發散に就て研究して 6 個の紫外部吸收帶を見出

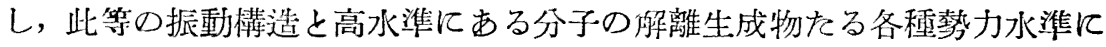
ある原子を決定せり。次に高壓放電により刺戟されたるナトリウムより發 散されたる黄赤帶スペクトルは $\mathrm{Na}_{2}$ 分子の吸收スペクトルの一部分と恒 同なるを示し之を振動，廻轉兩樣に分析して說明したり。木村正路氏(同 誌 18，129）は結晶による光の吸收の些質及び昇華熱を光學的に決定する 方法を研究し，金屬ハロゲン化物の結晶及蒸氣兩態に於ける吸收振動數の 差はその物質の昇華熱の近似值を與ふるを示し，タリウム，銀，アルカリ 金屬のハロゲン化物に於ては此關係の成立するを明かにせり。同氏(同誌 18,141) は沃化カドミウムのエネルギー氷準及び蒸氣絬晶网態の吸收振動 數の關係を研究し $\mathrm{CdI}_{2}$ の解離状態に就ての解離熱解離生成物のエネルギ 一水準的考察をなせり。同氏（同誌 18，150）は更に三原子分子の吸收ス 
ペクトル及びその解離生成物の研究を行ひ $\mathrm{CO}_{2}, \mathrm{NO}_{2}, \mathrm{~N}_{2} \mathrm{O}, \mathrm{H}_{2} \mathrm{O}$ 分子の刺 载狀沿によりて解離する生成物をスペクトル的に研究して夫љのエネルギ 一水準を示し, 同氏は冈因洋一氏 (同誌 18,157) と共にハロゲン化鉛の吸 收スペクトルを硼究してその熱解離に於けらエネルギー變化を算定せり。 同氏（同誌 18，166）は又夜間北極光椂の綠光の發散に就き考察し，空中 の酸素が刺戟せられて高ェネルギー水準に上るは日中太陽の輻射により窒 素と酸素分子が刺戟せられ兩者の衝突により酸素は更に高水準となるとし 之が綠光を發散するてとを示したり。長岡卅太郎, 二神哲五郎, 町田岩次 郎氏等 (SC. P. 19, 169) は破壞放電による鐵, ニッケル，チタニウムース ペクトル線の波長, 强度の變化を砰究し, 之等は力場壓力高溫電子, イオ ン分子の衝突等によるものとし之が星のスペクトルと或る相似性あるべき を指摘せり。

石田義雄，檜山茂兩氏（Sc.P. 19，79）は水銀スペクトルの單一項主 系列を研究し高電場に於ける水銀のシュタルク效果 $2^{1} \mathrm{P}_{1}-\mathrm{m}^{1} \mathrm{P}_{1}$ は $\mathrm{Mg} 三$ 重項 $2^{3} \mathrm{Pj}-\mathrm{m}^{3} \mathrm{Pj}^{1}$ と同じ状態なるを結諭せり。荒勝文策氏は大田，木村 氏（臺北理農紀 5,No.1) と共にバルマー系列に於ける各線に對しカナル 線より發射せられる水素の連續スペクトルは密接なる關係するてとを見出 し，之が强度は之の關聯せるバルマー系線の强度を决定する法則により支 配せらるべしとせり。同氏箩（同誌 5，No. 2）け更に長き管中に於ける 水素を通じて無極圓形版電をなせるとき生する特異現侜を分光學的に研究 せり。長岡牛太郎氏 (P. I. A. 8, 231) はネオンスペクトル線は波長の第 二次標潐として使用し得るやを論じて同位元素 Ne (22) の存在が之に障 害あるべをを示したり。正术康一氏 (Bull. C.S.J.7，353）は過酸化窒 素と Centralite との反隹考分光學的に研究してそつ生成物の化學構造老 決定し，デニトロ・ヂフェニルェチルニレアをるを見出したり。 
今泉善夫, 菊池健七兩氏 (北光 32,5$)$ は秋田縣產出の鑛石 6 栕に就て 分光學的に金屬成分を決定したり。植村环氏（東工學報 1,327,361）は オキシアท゙化合物水溶液の紫外線吸收とその水素イオン濃度との關係を研 究しメチル基，アゾ基，二トロ基，ヒドロオキシ基の吸收に及仿す影響を 示したり。河罒末吉氏 $(J . J . P .8,51)$ は半鍮に於ける銅及亞鉛の $\mathrm{K}-$ 吸 收スペクトルの椑造を研究し, 內田洋一氏 $(J . J . P .8,25)$ は黃赤 $\mathrm{Na}^{2}$ 發光帶スペクトルを研究して共鳴スペクトルの1種なるを明かにせり。

太秦康光氏 (Bull. C.S.J.7,85) は二オビウムの㯺化物, 硝酸鹽の水, グリセリン, メチルアルコール, エチルアルコール, アセトン, 溶液の吸收 スペクトルを比較して陰イオン溶媒の影響を論じをり。中村儀三郎, 四手 井綱彥兩氏 $(J . J . P .7,33)$ は $\mathrm{LiH}$ の分子スペクトルの同性骾效果を, 西久光氏 $(J . J . P .7,1)$ はアルカリ及アルカリ土金屬の硫酸監のラマン 效果を研究したり。今里與氏 ( Sc. R. T. Bunrika. D. A. 1, 179) は $\mathrm{Hg}^{\mathrm{II}}$ のスペクトル線の高擪に於て刺戟されたる場合の波長の偏差を研究し, 長 波長側江於て見らる」を示し之等の理論的考察を試み, 永島秀夫氏 $(S c$. R. Tokyo. Bunrika. D. A.1, 219) は AlH の發散スペクトル爆發アルミ ニウム蒸氣の溫度の测定を行ひたり。

× 線 櫻田一郎, 淵野桂六兩氏 (理研報 11，497,501) はアルカリ瀻維 素を又線的に研究し $\mathrm{Na}-\mathrm{Cell} \mathrm{II}^{\prime}, \mathrm{Na}$-Cell III' $る$ る化合物の生成を確めた り。次で繊維素キサントゲン酸曹達をX線的に研究して $\mathrm{S}=\mathrm{C}\left\langle\begin{array}{l}\mathrm{O} \cdot \mathrm{C}_{12} \mathrm{H}_{19} \mathrm{O}_{9} \\ \mathrm{~S} \cdot \mathrm{Na}\end{array}\right.$ の生成を確め, 之が主として Na-Cell I より成るを示し反應機構に就て 考察せり。庄司彥六氏（理研報 11，895）は物質の變態化上り生ずる結晶 䡃の方向變化に關する $\mathrm{X}$ 線的研究を行ひ鐵の As 變態點に於ける格子の 迵榑を考虑せざるときは本多博士の說と一致するを示し, 此際單結晶は多 結晶になるを見出し閃亞鉛鑛のウルツ石の變換に於ては閃亞鉛鑛の [111] 
はウルツ石の [001] に平行なるを決定し, 霞石 $\rightarrow$ 方解石の場合子霞石の 〔001]方向は方解石の [111] 方向へ本行せんとする傾あるを示したり。 向坂義太郎, 數元伊之助兩氏（理研報 11，135）は結晶體の熱的歪による $\mathrm{X}$ 線反射力の變化を水晶, $\mathrm{NaClO}_{3}, \mathrm{CaCO}_{3}$, 硫黄, 岩監飞就て測定を爲し, 士屋弘氏（理研報 11，1150）は低溫几生成したるモリブデン炭化物をX 線的に觀察して $\mathrm{Mo}_{2} \mathrm{C}$ は $\mathrm{Mo}$ 原子を $\left(\frac{1}{3} \frac{2}{3} \frac{1}{4}\right)\left(\frac{2}{3} \frac{1}{3} \frac{3}{4}\right) \mathrm{C}$ 原子を （000）の位置に置くを見出し, 平田森三E（Sc.P. 18，237）は火山灰及 火山岩による X 線趈折より研究して迴折像に 2 樣あるを見出し之が加熱 てよる變化を示したり。西山善次氏（東北理報 21，364）はデバイ,シェラ 一氏法による格子恒數の決定試料の厚さによる誤差の大なるを補正せん としフィルムの收縮及び試料支持器の偏位を考察し更に厚さの補正に就て は從來の補正式上り更に良好なる式を呈出し鐵，アルミニウムに就算出 したる格子恒数は夫ょ $2.861 \AA$ 及 $4.041 \AA$ なりとせり。仁田勇氏(本誌 35 , 713）は化學に對するX 線學の寄與に就て論述し，原子構造と X 線との 關係，化學結合を $\mathrm{X}$ 線の關係，X 線の化學作用を說明し更に X 線の結 晶構造の決定に寄與すること及び化學反應進行の機棈, 減摩劑の作用を說 明すべき手段の一なるを示せり。志村繁隆氏（本誌 35，1224）はX 線の 應用に就て主として結晶解析の方法を論じ，X 線てょる化學分析, 透過法 への應用を示し之等使用さるべき裝置に就き述べたり。

岩瀨虔三, 那須信行兩氏 (Bull. C.S.J. 7, 305) は電解的鐵, 二ッケ ル合金を $\mathrm{X}$ 線的江研究して $\propto$ 固溶體と $\gamma$ 固溶體との共有範圍は熔融て よるよりる廣を範園に於て存するを見出し電着機構を推論したり。山本研 一氏（本誌 35，1218）は酸性白土Ⓧ 線的研笲を行ひ酸性白土は結晶性 珪酸アルミニウムと非晶質含水珠酸とより成るとの推定を確めたり。高根

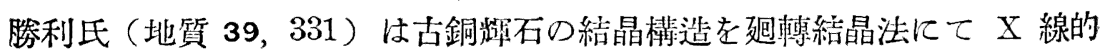


飞決定し單位格子空間群を示し, 石田義雄, 未次豊太郎兩氏 (Sc.P. 19, 185)はX線により放電管の密度分布を研究して壓力と密度との閵係を見 出し, 澤田正雄氏(京理紀 15，43）は橖 X 線の起原に就て考察し，俣野仲

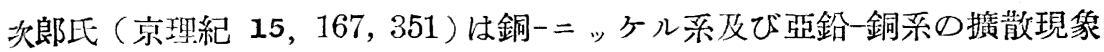
老X線的に呼究したり。志村繁隆氏（東工紀 20，1）はセメンタイトの 棈造を X 線により解明せり。石野又吉，小島公本兩氏(京理紀 15，293) は $\mathrm{Ni}, \mathrm{Cu}, \mathrm{Zn}$ と其化合物の $\mathrm{K}$ 系 X線吸收端は異ることを示したり。阿 部良之助氏（本誌 35，29，38）は㨗順炭液化に使用すべき接觸劑を $X$ 線 的に研究して反應後の變化を考察し反應との關係を示したり。

熱力學的硏究 石川總雄, 立木健吉兩氏（日化 53,551）は臭化ナトリ ウム及臭化カリウムに關する熱力學的研笁を行ひ溶媒としてアルコールを 用ふるの利點を示し $\mathrm{Na}-\mathrm{Hg} \mid \mathrm{NaBr}$ (S) 飽和アルコール溶液, $\mathrm{AgBr} \mid \mathrm{Ag}$ 及 $\left.\mathrm{K}-\mathrm{Hg} \mid \mathrm{KBr}^{\prime} \mathrm{S}\right)$ 85\% アルコール飽和溶液, $\mathrm{AgBr} \mid \mathrm{Ag}$ なる電池の起電 力方測定して臭化ナトリウム及び臭化カリウムの生成遊離エネルギー變化 及び生成熱含量を算出せり。植田勇二氏（日化 53，559）は硫酸リシウム の熱力學的研究学行ひ可逆電池の起電力测定, 溶液の蒸氣壓, $25^{\circ} \mathrm{C}$ に於け る溶解蓺, 反應熱の測定より $\mathrm{Li}_{2} \mathrm{SO}_{4}$ の生成遊離エネルギー, 生成熱含量 及びェントロピー變化を求め $25^{\circ} \mathrm{C}$ に於けるェントロピーを $38.7 \mathrm{cal} /$ 度 とせり。村田房一民（日化 53，322）は監化カリウム水溶液への鹽化カリ ウムの微分溶解及び濃厚溶液中に於りる監化カリウムの活度を研究して遊 離エネルギー變化学算出し含熱量變化，監化カリウムの活度係數と溫度と の關係を示し，更に硫酸カリウムに就て为同じ研笁を行ひたり（日化 53, 574 )。柴田榮一, 武田武兩氏 (J.S S . Hiroshima Uni. 2, 243) 屽鹽化銀 及臭化銀の熱力學的研究を行ひ $\mathrm{H}_{2}|\mathrm{HCl}(0.1003 M), \mathrm{AgCl}| \mathrm{Ag}$ 及 $\mathrm{H} / \mathrm{HBr}$ $(0.1003 M), \mathrm{AgBr} \mid \mathrm{Ag}$ の起電力の测定より臭化銀，暨化銀の $25^{\circ} \mathrm{C}$ に於け 
る生成遊離エネルギー，生成熱含量エントロピー變化及びエントロピーを 算出し, 柴田榮一, 尾田三郎, 古川靜雄氏等（同誌 2,85 ) は苛性カリウ ムの熱力學的研究を行ひ，生成遊離エネルギー，エントロピー，溶解熱を $25^{\circ} \mathrm{C}$ に於て算定し更に各種の水化物の解離壓及び水化に於ける遊離エネ ルギー變化を算出したり。柴田氏（同誌 2，215)は叉.詂性ソーダに就ても 同樣の研究を行ひ，正木康作氏 (Bull. $C . S . J .7,238)$ は硫酸亞鉛の活度 係數を $25^{\circ} \mathrm{C}$ に於て種々なる濃度に於て求めたり。石川總雄, 森一郎, 室 岡豊作氏等 (日化 53,181) は臭化カドミウムーエチルアルコール系の熱力 學的研究を行ひ遊離エネルギー, 熱含量, エントロピーを算出し, 同氏 等(理研報 11，999)は隹銅アマルガム電歌を應用して電池を作製しその起 電力測定より沃化銅, 臭化銅の $25^{\circ} \mathrm{C}$ 亿於㚈る遊離エネルギー, エントロ ピー，熱含量を算出したり。

化學平衡 田丸節郎氏 (日化 53，329，647）は其共同研究者と共にテル マノワーゲなる天科を使用して炭酸カルシウム及び炭酸ストロンチウムの 熱解離壓を測定し溫度との關係式在求め, 青山新一, 岡好良兩氏(日化 53, 417 ) は金屬マンガンの酸化還元平衡を研究して平衡式 $\mathrm{Mn}+\mathrm{H}_{2} \mathrm{O} \rightleftarrows \mathrm{MnO}$ $+\mathrm{H}_{2}$ 老得, $\mathrm{MnO}$ の生成熱含量變化老算出したり。秋野俊郎，宫崎兄一 兩氏 (九工彙 7,1 ) は $\mathrm{Na}_{2} \mathrm{SO}_{4}-\mathrm{H}_{2} \mathrm{SO}_{1}-\mathrm{H}_{2} \mathrm{O} 3$ 成分系の $25^{\circ} \mathrm{C}$ に於け る本衡を相律的に研究して $\mathrm{Na}_{2} \mathrm{SO}_{4}$ と $\mathrm{H}_{2} \mathrm{SO}_{4}$ 間の複監を決定し更に人絹 製造に際して生和硫酸中の䒙硝の包收法の最適條件を明かにしたり。奥 野氏は更に進んで別府次郎氏（同誌 7, 101） と共に $\mathrm{NaHSO}_{4} \quad \mathrm{Na}_{3} \mathrm{HSO}_{4}$ の加熱による分解壓の測定を行ひ溫度と分解の狀況を考察し分解生成物索 X線的に研究して $\mathrm{Na}_{2} \mathrm{SO}_{4}$ をる老決定したり。松原厚, 澤村武雄网氏 (地 質 39，343）は硫化鐵を熱分解して解離壓力を测定し且解離熱を算出し， 田丸節郎，鹽見賢吾兩氏（日化 53，1169）は水酸化カルシウムの解離赜測 
定値の少きためテルマノワーゲにて測定して $513^{\circ} \mathrm{C} に て 1$ atm となるて と老決定したり。不川總雄, 益田苦良, 萩澤浩氏繁（理研報 11, 1244）は 酸性硫酸ナトリウムの熱分解を研究し $240 \sim 250^{\circ} \mathrm{C}$ にて $\mathrm{Na}_{2} \mathrm{~S}_{2} \mathrm{O}_{7}$ の生成

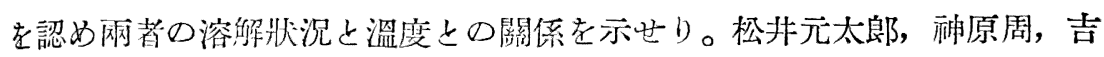
野晴方氏等（本誌 35，794）は膨張計に依り炭酸ナトリウムの轉移點を測 定し, 大幸甫氏（理研報 11，1323） は $\mathrm{NaI}-3 \mathrm{CH}_{3} \mathrm{OH}$ なる溶媒化合物の 轉移點が種々の物質の溶觸に依り如何に降下するかを實測し其值より該化 合物の融解㓐老計算せり。

粘度, 比重, 蒸氣壓 營義夫氏 (理研報 11, 877) は $2000 \mathrm{~kg} / \mathrm{cm}^{2}$ 迄の 高壓を加へ $18^{\circ} \mathrm{C}$ に於て種々のモビール油, 液狀パラフィン, 重油, 動植 性油の粘度を测定し県の粘度係數 $\eta$, 大氣垶中の粘度係數 $\eta_{0}$ 及び厴力 $p$ との關係が $\eta=\eta_{0} e^{\alpha p}$ ( $\alpha$ は恒數)にて表し得る事を認め, 高原知義, 薑監達 男网氏(神工報 2 號 1) は薄荷油心粘度は溫度の低下と共に大となり, 又 遊離メントールの量の增加と共に增加することを實驗したり。意藤大吉， 松川龍夫网氏（京工紀 7,49）は囫轉圓筒法に依り種々のアルミニウム合 金，銅合金の粘度t測定し熔融アルミニウム及び輕合金に於て 765 及 855 ${ }^{\circ} \mathrm{C}$ の 2 點に轉移點あるを認め之を熱解析及び電氣抵抗の测定により再確 認し又鑄鐵の粘度が䓰々の不純物に依りて蒙る影響を檢查せり。安積宏氏 （理研報 11, 1103）は種々の氣體及び氣體混合物の粘度を $20 \sim 100^{\circ} \mathrm{C} に$ 於て测定し, 粘度と組成との間に極大值するものと, 兩者分淔線的關係に あるものとの 2 種類ある事老見出し, 之等の結果几就て混合物の粘度に閵 するケーネンの式を吟味せり。

山本研一, 石川本七兩氏 (早應化 17，1）はルシャテリエ比重測定器を 以て $25^{\circ} \mathrm{C}$ に於ける各種酸性白土の比重を測定し 2.4 なる值を得, 侣各種 實驗誤差の理論的及び實驗的考察を篇し，三宅三郎，小城嚴丽氏（九工菓 
7, 72) はオルトニトロ安息香酸の水八の溶你度, 飽和水溶液の比重及比 容, 固態オルトニトロ安息香酸の比重及比容, 溶解に件ふ容積變化を测定せ り。佐川達四郎氏(金屬 9,189) は精彆せる四監化チタンの比重索 -18.10 〜 $109.60^{\circ} \mathrm{C}$ の䇢園に於て $5^{\circ} \mathrm{C}$ 每に测定し熱膨張の實驗式を決定し又粘度

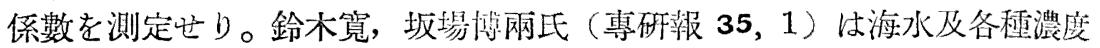
の嵅水の一般及びボーメ比重を $15 \sim 80^{\circ} \mathrm{C}$ に於て测定し之等比重と溫度女 の直線的關係を認めたり。

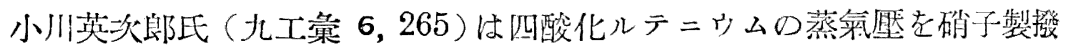
條壓力計を用ひて $0 \sim 79.77^{\circ} \mathrm{C}$ の範圍に於て湘定し, 蒸氮塬と溫度との關 係の賽驗式を見出しその圖上より, 又影微鏡に依る直接觀察より其融點を $25.6^{\circ} \mathrm{C}$ 上沈定し, 同氏 (九工彙 7, 14;Bull. C.S.J. 7, 265) は七二酸

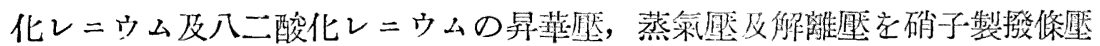
力計を以て測定しノダック氏の報告に 2〜3の訂正を加へうり。小林要三 氏（廣理紀 2, 269) は可逆電池 $\mathrm{H}_{2}(\mathrm{Pt})|\mathrm{KOH}(\mathrm{m}) \mathrm{HgO}| \mathrm{Hg}$ の起霄力及び 新に計算せられたる水蒸氣に對する狀態式 $p[v-(b-c p)]=B T$ より 25 ${ }^{\circ} \mathrm{C}$ に於ける 20 モルに至る迄の各濃度に於ける苛性カリ溶液の水蒸菊壓 を算出せり。橫田泰三氏（物理化學 6,63）は水溶液の蒸氣壓と濃应に關 し现論的考察をなし又飽和溶液に於ては蒸氣壓と濃度の間には溫度に無關 係なる數式が成立する事を實驗的に發見せり。堀內壽期氏（日化 53，47; Sc. P. 17, 257) は $18^{\circ} \mathrm{C}$ にて空氣老飽和せしめたる程及の有機溶劑の密 度は空氣を含まざるるのより小にして大體小數點以下 4 位丈は 5 位に影 響し又有機溶劑の蒸氣壓の测定值の區々たるる空氣の影響たる可きを論ぜ b。

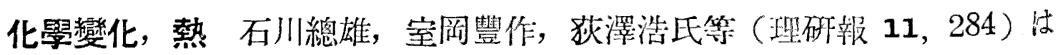
重炭酸ナトリウムを 350 文 $500^{\circ} \mathrm{C}$ にて分解せしめて得たる炭酸ナトリ 
ウムに夫ぬ $150 〜 300^{\circ}, 250 〜 600^{\circ} \mathrm{C}$ に於て監素を作用㕱しぬ $2 \mathrm{Na}_{2} \mathrm{CO}_{3}+$ $\mathrm{Cl}_{2}=4 \mathrm{NaCl}+2 \mathrm{CO}_{2}+\mathrm{O}_{2}$ の式にて示さる れる炭酸ナトリウムが $500^{\circ} \mathrm{C}$ て作れるるのより遥に作用し易さを認め, 石川總雄，荻澤浩网氏（同誌 11，297）は岑酸カリウムに就ても同樣の䔈 驗を行ひ同樣の反應行はれ且っ $350^{\circ} \mathrm{C}$ て作れる炭酸カリウムは $500^{\circ} \mathrm{C}$ にて作礼るものよりも反應し易きも反應溫度 $450^{\circ} \mathrm{C}$ 以上にては网試料同 一結果を與ふるを見，此事實を比重測定の結果見出したる $410 〜 420^{\circ} \mathrm{C}$ に 於ける轉移點より說明老與へたり。尾藤堅, 青山涬造, 松井元太郎氏等（本 誌 35，553）はネルンスト氏トーション科を用ひ氷洲不の分解點を测定し 928 $929^{\circ} \mathrm{C}$ の值を得, 又之を炭酸瓦斯氣流中にて加熱する時 $914 \sim 915^{\circ} \mathrm{C}$ 及 $928 \sim 929^{\circ} \mathrm{C}$ の 2 點にて分解する在認め, 又同氏等（本誌 35, 559）は ネルンストミクロトーション科走用ひ乾燥空氣氣流中に於ける硝酸荅鉛の 分解點及生成せる酸化蒼鉛の蒸發點老測定し夫々 $440,855^{\circ} \mathrm{C}$ なる值を 得, 松井元太郎, 神原周, 宮村勝治㚤等 (本誌 35, 657) は對照熱量計を 用ひて $25^{\circ} \mathrm{C}$ に於て 1000 モルの水に對する 1 モルの炭酸ナトリウムの溶 解熱を測定し 5670.8土8.1 cal を得をり。

山本洋一氏（理研報 11，834）以鼠鑄驖を監酸にて腐蝕せる後空氣中に

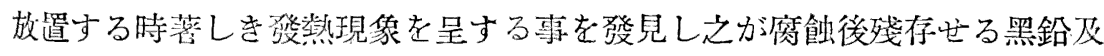
炭化鐵より成る多孔質表皮の酸化に基くことを觀察し，發熱現像と腐蝕の 關係に諭及し，同氏(同誌 $11 ， 1157 ; S . S c . P .16,1$ ) は硝酸にて處理す る場合も同一の現集あるを認め，種心の濃度の硝酸を用ひ空氣中に於ける 試料の溫度と時間との關係, 溶液の濃度と腐飿減量の關係を研究し硝酸の 鐵に對する作用を論じ，份（同誌 $11 ， 1215$ ) 硫酸に於ても同樣の試驗をな し或る浱度の硫酸に於て發熱量極大に達する事を見たり。同氏（電鋼 8 ,

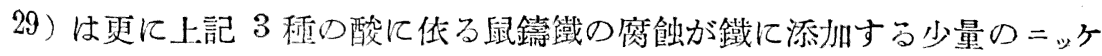


ル及び銅に低り如何なる影響を蒙るかを研究せり。橫田俊雄，磯谷延治兩

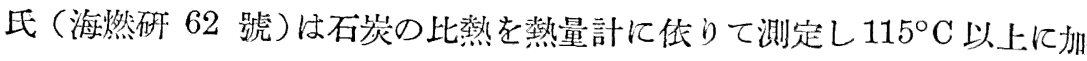
熱せるもの」比熱は筫测值と計算值とは一致すれ共然らざるものは實测値 の方大なるを見, 石炭中に含有出らる小酸素と水素の結合狀態に諭及せり。 鈴木庸生, 堀江忠一兩氏 (理研報 11,1 ) は太陽㬏射ェネルギーを化學的工 ネルギーに變化せしめん目的の豫供蜜驗として種々の紙類, 七ルロイド,确 子等の熱逸出度及び之等の材料を以て作れる蓋を索せる熱箱を太陽に露出 する時の箱の內部の溫度上昇速度立測定此較せり。阿部良之助, 藤川重雄, 杉山邦一氏等 (本誌 35, 1251) は $\mathrm{Fe}_{2} \mathrm{O}_{3}$ の存在の下にて高醴空素下の石 炭の加熱變化を $350 \sim 500^{\circ} \mathrm{C}$ 亿於て觀察し $450^{\circ} \mathrm{C}$ 迄は石炭糊は全く均一に して溫度に無關係に $17 \%$ 前後の油分を生じ又炭化水素の役生僅少なれ共 $500^{\circ} \mathrm{C}$ に達すれば全く骸炎化し念激に油の收量を減少し岑化水綮は $20 \%$ に急增する事を認め，同氏等 (本誌 35, 1257) は同樣の實驗を高態水素下 にて行ひ油の收量は䇪素の場合より增加せるも $450^{\circ} \mathrm{C}$ にて貎に䯓炭化 が起り又脫水素作用も起り水菜吸收量の意外に僅少なるを認めたり。小田 良平，野間元誠次兩氏（本誌 35，1357）は二重結合を有する有機化合物( 加熱による分子切斷點が何處に起るかに關するシュミット氏法則を擴張しェ ーテル類の熱分解，第3アルコールの熱分解によるケトンの生成，有機酸 の解離度と二重結合の法則との關係等に論及让)。久保时桐造氏(日化 53， 409 ) はオルト及パラニトロクロルベンゾール並に 2.4- 及 2.6- ヂ=トロ クロルベンゾールの各兩者系の融點曲線を賽测作製し之等 4 種の物質の分 子融解熱在計算せり。

溶解 近藤金助上（日化 53，880）は蛋白の溶解現集に關し監類の蛋白 解離イオン化說なる新說を提唱し實驗的の例證をる與へたり。小林久平， 山本研一兩氏（本訫 35, 1282）は種々の粘土類のアルカリ溶液に對する 
溶解度老测起し珠酸及アルミナの溶出量に依り含水珪酸アルミニウム化合 物類中の珪酸及アルミナの結合狀態を略推察し得る事を示し, 佾(本誌 35,

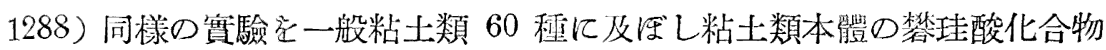
の大略分類の指針を示し又粘土類分析法の改良法を述べたり。板野新夫， 松浦幛网比（農研 19, 377）は土壤溶液の乾燥に依る物理化學的性質の變 化を調查し, 堀省一郎、久保田䅡兩氏（化工資 5, 3 號 32 ）は硫酸アンモ ニウム溶液の溶解度と比重在测定し, 山本健磨上（化學總覽 6,93B）は 1930 年以後に發表せられたる化合物, 單唱營の溶解度数值を 聚集表示せ り。渡邊荿次郎氏（岩石 7，251）は雄黃並に輝安鑛の酸及アルカリに依る 溶解及沈澱を 0 〜 $100^{\circ} \mathrm{C}$ に於て觀察し種及の酸化齊利の添加に依る影響を檢 し該鑛物の成因を唀察せり。森安靜太氏（本誌 35, 702）は鉛㗂子の水に 對するアルカリ溶解量と $\mathrm{K}_{2} \mathrm{O}: \mathrm{Na}_{2} \mathrm{O}$ との間の關係を實驗的に定めたり。

堀內壽郎氏（理研報 11，55）は水素, 酸素, 空素, 一酸化岑素及メタンを 溶質とし四監化炭素, ベンジール，クロルベンジール，醋酸メチル，エー

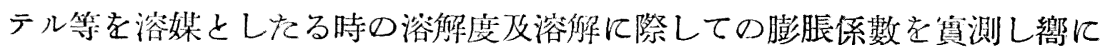
得たる理論式の適否を調べ，庄野信司，小林䔀网氏（臺督研工報 73 號 17) は 21 種の溶劑に對する常盟下のメタンの溶解度と溫度との關係を實測し 之を溫度を變数さする二次曲線にて卦現して此較せり。上原弘衞氏（日化 53,931) は水素及メタンの液態エタン中への全壓 1 atm に於ける溶解度 を測定せり。八田四郎次氏（本誌 35,1389 ) は液娟への瓦斯の吸收速度に

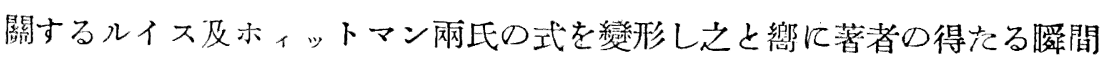
反應に依る吸收速度の理論式と比較し佾僢間的ならざる反應に依る吸收速 度り理論式を新に誘導せり。同氏 (本誌 35，1397) は炭酸瓦斯の炭酸カリ ウム溶液中への吸收速度を測定し前報に得たる理諭式と一致する事を明か にせり。宮本進氏（Bull. C.S. J. 7, 8) は氣體の液瞜への溶解度に就て 
新理論を提出し之を表はす理論式を誘導し著者が激に測定せる亞硫酸ナト リウム溶液の酸素に依る酸化速度を說明し，又(同誌 7, 388; 日化 53, 1005）分子運動說を基礎として瓦斯の液艠への初溶解速度理論を誘導し之 を搌散屡說より得られをる理論と比較し新理論よりヘンリー氏法則を導を 出し又氣體液體間に於ける物質の分配率に關し全く同一の基礎より論じた

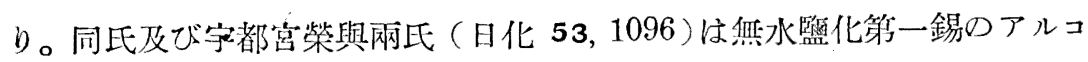
一几溶液中への酸素の溶解速度と濃度との間の關係支實测し之と前報の初 溶解速度理論飞依りて檢討ぜり。正木清氏 (Biochem. 15, 29) は $1 \mathrm{~N}$ 菏性 カリ溶液の炭酸瓦斯吸收速度は同濃度の苛性ソーダ溶液に比し $11 \sim 25^{\circ} \mathrm{C}$ の範圍內に於ては 1.14 倍大なる事を認めたり。

反應速度 青野武雄氏 (Bull. C.S. J. 7, 143) は 780 $1030^{\circ} \mathrm{C}$ に於け る炭化カルシウムの窒化速度は窰素の厴力 $(P)$ 亿正比例せ亦して $\frac{-d P}{d t}=$ $K_{1+a P}$ の式に依て與へらる〉事及で溫度の上昇と共に筑素の壓力增加の 反應速度に及代す影響增大寸る事老認め, 向（同誌 7, 247）950 及 1000 $\sim 1060^{\circ} \mathrm{C}$ に於ける空化度を與ふる數式を提出し又各溫度に於て窒化速度 に極大值の存在を認め且っ速度恒數の溫度系數より工業用炭化カルシウム の $1000 \sim 1060^{\circ}$ 及 $1080^{\circ} \mathrm{C}$ 亿於ける見掛けの活性化熱を計算せり。同氏(同 誌 7, 274) は次に粒狀炭化カルシウムに於ては恒溫恒厔の下の窒化速度は 粒の表面積に比例し, 粒の牛徑上の窒化速度は $1140^{\circ} \mathrm{C}$ に於ては一定なれ

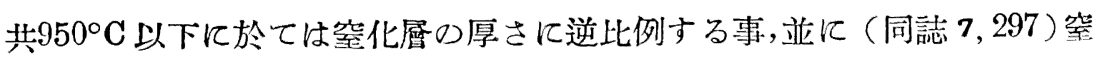
化速度を最大ならしむる䉆に添加する觸媒弗化カルシウムには最適量存在 する事, 炭素及炭素を放出す可き物質は强き接觸作用を有する事等を觀察 せり。石川總雄, 荻澤浩兩氏 (理研報 11, 527) は過鹽素酸ナトリウム及カ リウムの加熱分解を熱天科法に上りて研究し前者は $460 \sim 540^{\circ} \mathrm{C}$, 後者は $550 \sim 580^{\circ} \mathrm{C}$ にて分解するも對應する炭酸遥の添加に上り分解溫度低下し 
且っ分解速度㫮大寸る事を認め, 又過監素酸ナトリウムの恒溫分解速度曲 線は自觸反應の類型に屬する事老知り其に關する數式を提出せり。絹然 丞, 箕作新六网氏（日化 53,398）は液體監素と氣體エチレン間の反應速 度を一 $78^{\circ} \mathrm{C}$ に於て测定し大體に於てェチレンの分壓に比例したる反應速 度老示事を知り, 森口信男, 佐藤恭三网氏（日化 53,708）はカリウム アマルガムと稀硫酸との反應に於て一定溫度に於ける反應速度はアマルガ ムの裖度には無關係にして硫酸の濃殿に正比例寸れ共反應の終期に於て曲 線的關係となり又凤應速度の溫度係數は硫酸の擴散恒數の溫度係數に等 L きとよを見たり。宮本進氏（Bull. C. S.J.7, 56 )は第一錫監の酸化速度 が苛性りンダ, 監酸, 硫酸等の少量の添加に依りて著しく垻大寸るは或種

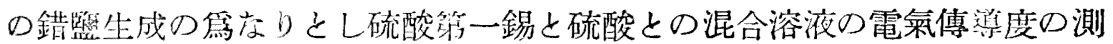
定江低り $\mathrm{H}_{2} \mathrm{Sn}\left(\mathrm{SO}_{4}\right): 3$ 及 $\mathrm{H}_{2} \mathrm{Sn}\left(\mathrm{SO}_{4}\right)_{2}$ をる 2 種の錯儖の存在する事を示 せり。

中鴆㙷三比（農化 8, 36）は種くのカタラーゼの過酸化水素分解速度を 測定し其結果が著皆の提唱する一般反應式 T. N. N. I 及 II 式の何れか

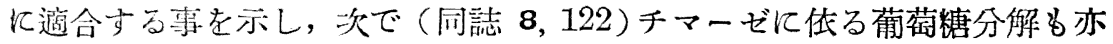
此式に適合する事庄示し著者が從來發表せる多数の報告結果に結論を與へ

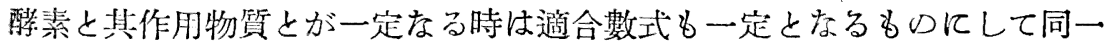
の化學機作に依る適合式は單一一定なりと論じたり。同氏（同誌 8, 229） は時間を一定にし酵素量を變化せしむる場合の反應式が T. N. N 式の時 間の項を酵素量の項にて置き撸へたる T.N.N.（E）式を以て表は.し得る 事を種々の陵素に關する前人の實驗結果に就て例示せり。同氏（同誌 8，475,1140）及鎕田寅八氏（同誌 8, 373,685）は更に多数の實驗結果に 就き上式の適否を調查也り。武富搨, 堀越武雄网比(早應化 18 號 4) はイ ンヴェルターゼの作用䢞度注基使用量に比例せ和酵素量の增加に從て單位 
酵素量に依る作用速度減少与る事を認めたり。

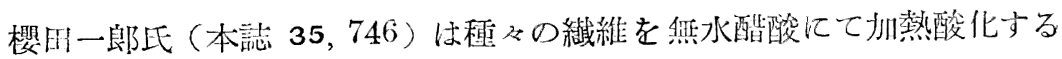
場合エステル化度 $(x)$ と反應時間 $(z)$ の間に $x=k z^{m}(k, m$ は恒數)の關係 あること並に硫酸を觸媒として無水醌酸と水酷酸の混酸にて醋酸化する場 合ェステル化せる表面上よりの䋊維の溶解速度は不溶解部分の表面積に比 例することを實驗的に見出し, 同氏及庄司野正雄氏（本誌 35, 751）は種 ふの㵶維の确化の反應速度が同じく $x=k z^{m}$ なる式にて表なし得る事を證 明し椣たの試料に就て $m, k$ の值を表示せり。山本永之助, 五岛類治, 旸島 二郎氏等(本誌 35,767 ) は監化デアジニウム・クロルベンジールの3 種の 買性體の水溶液中に於ける分解速度を测定し速度恒數を算出し, 同氏等 (本誌 35,1407 ) は更にオルト・アニシヂン,パラニトロ・オルトアニシヂン, オルト・ントア リンの各デアゾニウム誘導體の 分解速度に關して同樣 の賽驗を行ひたり。山田貞吉氏（本誌 35,574 ) は鑛油に各種の有機酸を 添加する場合酸素吸收速度は增大し, 又(本誌 35, 1165)アルコール類を 添加する場合は一般に增大しェステル類はそれに含まる〉酸に低り著しく 態度を異にしヂオキシ・アセトン，グリセリン・アルデヒド等は著しく酸素 吸收を促進する事を觀察せり。堀場信吉, 馬場日出男兩氏（物理化學 6,47) は過酸化水素の紫外線に依る分解速度及反應熱学熱解析法に依り测定し， 後藤廉平氏 (物理化學 5,152 ) は $2 \mathrm{NO}+\mathrm{O}_{2} \rightarrow \mathrm{N}_{2} \mathrm{O}_{4}$ の反應速度を $-95^{\circ}$, $-116^{\circ},-126^{\circ} \mathrm{C}$ 亿於て測定し何れも三次反應なる事を走し, 速度恒數は 溫度の下降と共に增大するを明かにし，野口達彌氏（工篻 1，42）は化學 反應速度恒數計算法の改良法を發表せり。

接觸作用 阿部良之助氏（本誌 35，32）は古城子炭と流動パラフィンの 同量混合物に石炭の $10 \%$ 亿相當す万觸媒第一酸化鐵を加へ $400^{\circ} \mathrm{C}$ 几於て 最高壓力約 $200 \mathrm{~kg} / \mathrm{cm}^{2}$ を以てベルギン反應を行ひ反應中の壓力の變化及 
生成物を檢查し石炭淡化最宫率 $34.79 \%$ 老得をり。同氏(本誌 35, 29, 38)

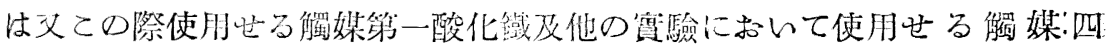
三酸化鐵つ反應後に於ける還元狀態を $\mathrm{X}$ 線を以て觀察し, 次で（本誌 35, 1015 ) 流動パラフィン中に觸媒四三酸化鐵を入れ $350 \sim 500^{\circ} \mathrm{C}$ に於て初壓

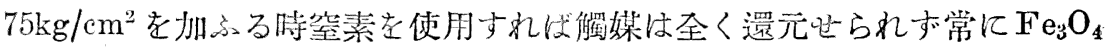
のみ殘るも水素を使用する際には $\alpha-\mathrm{Fe}$ が混在し溫度の上昇と共に其量增 加し $500^{\circ} \mathrm{C}$ に達すれ代全部 $\alpha-\mathrm{Fe}$ に還元せられる事を $\mathrm{X}$ 線的に確めた り。田中芳雄，小林良之助兩氏（本誌 35,52 ) はニッケル解媒を以て脂肪 油の高壓水素添加荙行ふに當り反應メヂウム中に酸性白土を其吸着の特性 を保有する狀態に於て存在せしむる時は水素添加反應の速度著しく促進邑 らる〉事實を認め，乙れは脂肪油の不飽和價標を有する岑素原子が白土に 吸着せられ以て該原子間の絬合を薄弱ならしむる鹞なりとせり。藤村建次 氏（本誌 35,532）は一酸化炭素の常壓接觸的還元に依るベンチンの合成 几於て觸媒製造に際し澱粉を添加して艮好疗る絬果を得 $\mathrm{Co}-\mathrm{Cu}-\mathrm{Th}-\mathrm{U}$ 觸 媒に依て混合瓦斯 $\left(\mathrm{CO}: \mathrm{H}_{2} \doteqdot 1: 2\right)$ を 1 回通過せしめその $1 \mathrm{~m}^{3}$ より 142 $\mathrm{ce} / \mathrm{m}^{3}$ のベンチンを合成せり。同氏文常岡俊三氏(本誌 35,1021 ) は同樣 の實驗に於て触媒に X 線を作用せしめたるものと然らざるものと老比較 しベンチンの收量に於て兩者に差異なきとをを認的り。小四良本氏（本誌 $35,858)$ はステアリン酸及そのエステル, 大豆油, 篦麻子油,オリーブ油 等を珪藻土を据體としたる 銅䚡媒を用し水素初壓 130１40 atm の下に $320^{\circ} \mathrm{C}$ 附近に於て還元し相當するアルコールを約 $80 \%$ の收量を以て得， 尚此際試料中にベンゾール, ェーテル,アルコール等を加ふる時は還元が 著しく防止せられることを見出せり。安東新午氏 (本誌 35,1119 ) は石炭 酸 1 分子に對し 3 分子の高珤水素を加へアルミナを添加せるニッケル觸媒 を以て還元を行ふ常溫より速續的に加熱し $360^{\circ} \mathrm{C}$ に 30 分間保持し反應 
生成物としてシクロヘキサノール，シクロヘキサノン, シクロヘキセン,ベ ンゾール等を得その生成の機棈を論ぜり。田中考雄, 小林良之助, 西野榮 一氏等 (航空研柴 95 號, 559) はモビール油, 未洗マシン油, マシン油の 3 種潤滑油を $300^{\circ} \mathrm{C}$ 以下の溫度に於て酸化ニッケル又は之に酸化銅を混和

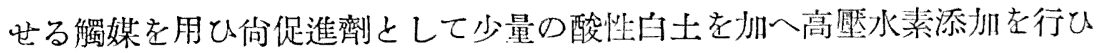
水素添加油の性狀と原料油の二れとを比较し水溸添加は潤滑油の精製又㤌 仕上の方法として適當なる事を認め, 土屋知太郎, 石川得三网氏（東工試 27,11 號 53) はリノレン酸メチルを $180^{\circ} \mathrm{C}$ に於て二ッケル觸媒を用して 水素添加を行ひ最初はオクタデカヂェン酸メチルの生成が殆ど完全に選擇 的に進行し試料の全部が該物質に變化せる後始めてオクタデセン酸メチル 及ステアリン酸メチルの生成せられる事在見, 晌反應生成物中の種《の異 性體の構造檢索を行ひたり。吉川清氏（Bull.C.S.J.7, 201）はパラヂ ウム1：珪藻土 500〜1500 の割合を以て製したる觸媒を用ひアセチレンの 水素涯加を行ひ $150 \sim 200^{\circ} \mathrm{C}$ に於て $90 \%$ の收量を以てェチレンを得, 儡 媒作用に於ける促進劑及擔體の任務に就て論ぜり。

俈及木一雄氏 (束工試 27,3 號 1) は白金觸媒を使用して加壓下のアム モニアの接噣的酸化法を利究し瓦斯つ流速と溫度とを適當にすれば $8 \mathrm{~atm}$ 迄は常厚下の場合と略大差度き良好洨る酸化成績を得可き事を發表せり。 同氏 (同誌 27,3 號 42) は又高濃度のアムモニアの接觸的酸化に於て觸

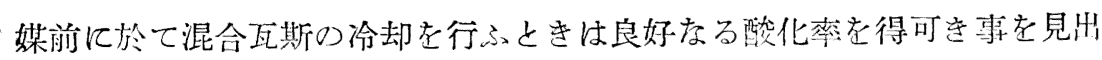
し酸素アムモ $ン ア$ 混合瓦斯を使朋して長時間に亘り酸化率 $90 \%$ 以上を得 たり。吉村倫之助氏（本誌 35, 294）は水性瓦斯反應に依る水素製造解媒 の研究に於て $\mathrm{Fe}_{2} \mathrm{O}_{3}$ の處理溫度と酸化接㒔能との間の關係を求め $700^{\circ} \mathrm{C}$ 附近に於て脫活が行はれ同時に噣媒の收縮が行はる小事老認め, 其原因を 微細結晶粒の角及稜の渻失に蹛せり。侣 $675 \sim 680^{\circ} \mathrm{C}$ に於て $\mathrm{Fe}_{2} \mathrm{O}_{3}$, の袎 
氣變態行はる」事索差熱分析法に依りて確めたり。同氏（本誌 35,800 ) は次で $\mathrm{Fe}_{2} \mathrm{O}_{3}-\mathrm{Cr}_{2} \mathrm{O}_{3}$ 系䪅媒に於て $\mathrm{Fe}_{2} \mathrm{O}_{3}: \mathrm{Cr}_{2} \mathrm{O}_{3}$ 亿依る磁氣變態點の移 行及收縮開始溫度の變化を調查し兩者の間に不離の關係なきこを論じを り。池田鐵作，小倉䇺二郎兩氏（臺督研工報 73 號 1）は各璉金屬及金屬 酸化物を触婑としてメタン一水蒸氣反應を研究し一酸化炭素及水素の生成 几良好なる結果を與ふる䚡媒としてニッケル及之と他の難還元性金屬酸化 物の混合物を舉げたり。

桑田纨, 立開靜兩氏 (本誌 35,773 ) はカムフェンと苳酸と口反應に訨 るイソボルネォールの合成に於て珪酸ら゙ルが有效なる觸媒として作用する 事を發見出り。角谷清明, 山田昌, 田島義正氏等（本誌 35, 307; 大工陚 12,18 號 1)はアセトアルデヒドより醋酸エチルを合成する際使用せらる 〉觸媒アルミニウムェチレートの製造方法を比較研究し沃素, 昇录と共に 適量の無水監化第二鐵を觸媒として用ひ好結果を得をり。木村清三氏（日 化 53，497）はゲラニオール及リナロールを活性炭と共に $220^{\circ} \mathrm{C}$ 附近に於 て約 20 時間加熱しミルセン, ヂペンテンを得, 次で同氏 (同誌 53, 777) はチトラール及チトロネラールに活性岑を作用せしめ前者よりはパラシモ 一ル及 $\mathrm{C}_{20} \mathrm{H}_{28}$ の組成を有する炭化水素, 後者よりはイソプレゴール及 微量の 1 桖のテルペン炭化水素の生成せらる」を見をり。田丸節郎, 相井 春雄兩氏 (日化 53,852$)$ は酸化ストロンチウムと酸化錫とより錫酸鹽生 成の接觸反應を政究し觸媒として水素と用ひ它る場合生成物は $\mathrm{SnO}_{2} ・ \mathrm{SrO}$ なる組成を有し一酸化炭素を用ひをる場合は $2 \mathrm{SnO}_{2}$ ・ $3 \mathrm{SrO}$ なる組成を有 する事を見出し二っの場合に於ける反應機構を諭じ各種反應の平衔恒數を 決定せり。牧銃夫氏 (本誌 35,1437 ) はベンズアンスロンの苛性加里熔融 に當り石炭酸の如きフェノール類を適量添加す行代ヂベンズアンスロンの 收量著しく增大寸るを認めたり。熊本伸一郎氏 (日化 53,28 ) は $200^{\circ} \mathrm{C}$ 亿 
加熱せる還元銅の上にイソアミルアルコールを通じイソヴァレルアルデヒ ドと共にイソ䋶草酸及其のイソアミルルェステルの生成を認如其生成機構 をカンニツっロ反應に歸せり。山口文之助氏(日化 53,54)はオリーヴ油の 酸化に觸媒として使用せらる」油酸銅其他の所謂乾燥劑の任務を諭じ油中 飞含有せらる」不鳐物の酸化防止作用の抑制, 油の酸素附加反應の妨碍, 油の酸化生成物の分解の促進の3にありとせり。次で（日化 53,63）トリ オレインを用ひて同樣の實驗を䨐し同樣の絬論を得たり。同氏（日化 53, 1134）は叉油酸の酸化がヒドロキノンの存在に低て防止せられ而してその 防止作用が油酸銅に依て抑制せらる」事實を認めその原因圭論ぜり。土屋 弘氏（理研影 11, 1136)はモリブデン及その岑化物を用ひ一酸化炭素の接 觸的分解を行ひ反應の前後にX-線的研究をなし $450 \sim 600^{\circ} \mathrm{C}$ て於て $\mathrm{Mo}_{-} \mathrm{C}$, $800^{\circ} \mathrm{C}$ に於て $\mathrm{Mo}_{2} \mathrm{C}$ 及 $\mathrm{MoC}$ の生成する事實を認め又モリブデン及その 炭化物の表面に於ける活性化されたる炭素の行爲を述べ一酸化炭素の接觸 的分解の機教を說明せり。等川県男忯(物理化學 6,81) は白金表面に於け るメタンの接觸分解の反應速度解析より岑素が不可逆吸着により强き抑制 作用を表はす事を推論せり。木村五郎氏（特許公告 No. 2174）は廢亲二” ケル觸媒再生法を，島五郎氏（特許公告 No. 1129）はアルコール類合成 用觸媒の製造法を，兵藤藤吉氏(特部公告 No. 1317) 緲媒法に依る純硫 酸の直接製造法を，竹中寬氏（特許公告 No. 1895）は水蒸氣を使用しメ タン又は之を含有する瓦斯の接觸的酸化に依る水素と岑酸瓦斯混合物の製 造法を，又佐々木一雄氏（特許公告 No. 322）は早金屬觸媒と貴金畓觸媒 とを併用するアンモニア酸化法を發明せり。

收着, 界面張力 䚗島實三郎氏 (Bull. C.S.J.7, 133) はシリカゲルに 依るアムモ $=ア$, 炭酸瓦斯, エチレンの收着速度を $25^{\circ} \mathrm{C}, 1 \mathrm{~atm}$ の下て 测定せり。次で同氏（同誌 7,177）は多孔質同體に依る純粹なる瓦斯の一 
定壓の下に於ける收着速度の熶初の段階が $d x / d t=k(s-x) / x^{n}$ を以て表は さる〉事を理論的に導き出し多くの著者に依て既に發表せられたる數值が 此式によく一致する事を認め, 又(日化 53, 1129) 純粹なる氣體が一定壓 の下に於て多孔質固體に依て吸はれる際の第 2 段の收着速度を表はす式と して部に是出せる式 $x=a \log t+k$ が空氣と混合せる蒸氣が固體に吸はれ る際の速度にる適用儿得万事圭明かにせり。

田丸節郎, 落合和男兩氏（日化 53,629）は檜及樅材の吸濕量、脫濕量 並に吸濕、脫濕に件ふ伸縮率索测定し, 吸濕の場合には兩者共にヒステリ シスを示出共伸縮の場合は樅に於てのみヒステリシスを認めらる」事を見 出し, 又伸縮率上り計算せる體瞔の膨脹率と吸濕量とが略直線的關係にあ る事を示せり。近藤萬太郎, 岡村保兩氏（農研 19,143）牥乾燥玄米が吸 濕する場合其膨脹の割合が方向に依りて異をる事を見出し此事實を以て玄 米の胴割を生ずる原因となせり。

田中芳雄, 桑田勉, 古田迪氏等 (本誌 35,649 ; 東工紀 20,53) 柱種名 の色素の水溶液中に於ける酸性白土一の吸着を研究し㿼基性染料の吸着は 主として色素監基と白土表面上の活性珪酸との造監反應俍りて惹起せら れ吸着量と白土の酸性度とは逆行し邓酸性染料の吸着は主として色素なる 色素酸監上り色素酸を遊離せしむる事に依りて起り吸着量は該色素酸の水 に對する溶解性に關係する事を認め水中に於ける酸性白土の活性面に關す る考察を述べをり。佐多直康, 倉野勝三兩氏 (日化 53，617）は種々のべ ンゾール二置換體の三の異性體の種々の有機溶媒中に於ける活性炭への吸 着量を測定し吸着量と各溶媒の溶解力とが逆行し又有極性溶媒よりの吸着 が無極性溶媒よりの吸着よりも大なる事を見出せり。山本鿆二郎氏(早應 化 17 號 15)はベンゾール吸着劑として沼鐵鑛を使用する事を提案し不純 物少き且つ化合水多き沼鐵鑛を適當の溫度にて燒鐄せるものはベンゾール 
蒸氣約 $160 / / 100 \mathrm{~g}$ の吸着力西り, 叉反覆使用に堪へ得方事在報告せり。在 川總雄, 佐野幸吉爾上 (日化 53，703）は恒溫に於て酸化マグネシウムに 水蒸氣を吸收せしぬ其吸收量と壓力との關係並に吸水量と壓力, 溫度との 關係を吟味し之等の結果が何机子吸着現管としてょく說明し得る事を示 し，水和作用が第 2 段の反應として極徐々飞進行するものなる事を明かて

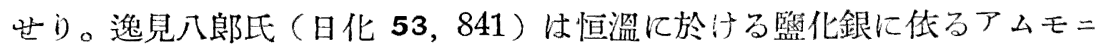
ア瓦斯の吸收速度老测定し 3 アミノ監化銀と 3 アミノ2 監化銀間の轉移點 並に 3 アミノ2 監化銀の轉移點を決定世り。長谷信一郎氏(本誌 35,890 ) は凝固浴の組成が直接染料吸着性に及伍す影響を檢し又染料の吸收度と凝 固速度，絲の伸張度，斷面の形狀との間には普遍的なる一定の關係なきを 認め，似波猛，伊藤貞志兩氏（本誌 35, 1178, 1184）はゴム月カーボン黑 10 種に就きデフェニルグアニヂン, 荝泾ソーダ, 醋酸、沃度, マラカイト グリン，メチレンブルー，亞唹仁油及び水蒸氣の吸着量を测定しデフ ${ }_{x}=$ ルグアニヂン，沃度，醋酸に就ては吸着等溫線を求めフロインドリッヒ氏 式の適用せらる」事を認めたり。

玉虫文一氏 (Bull. C.S.J.7，168) は正脂肪ヂカルボン酸の水溶液の表 面張力を $0 \sim 0.5 \mathrm{~mol} / l$ の濃度に於て測定し表面張力降下と濃度と虹直線的 關係をなし且偶數個の炭素を有する酸の間に於てはトラウベ氏法則の成立 する事を認め, 之を理論的飞說明し丈水溶液中飞於斿る獸岑への吸着能の 順位を測定し各酸に於てフロインドリッヒ氏等溫式の成立する事を見たり。 外村德三, 中條檠兩氏 (Bull. C.S.J. 7, 259) は土チルェーテル, アセ トン，トルォール，メチルアルコールの表而張力を常溫より $-100^{\circ} \mathrm{C}$ 几至 る範園に於て測定し其檤をエトボス氏式より計算せるものと比較し，城所 明二氏（同誌 7,280）は種々の無機留水溶液とへキサンとの間の界面張力

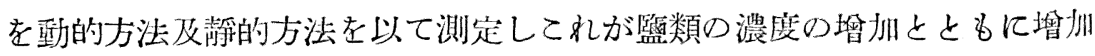


し且っ溶液の表面張力の整加と殆ど本行なる事を認めたり。伊藤武雄氏(農 化 8，908）は訬種のアミノ酸の水溶液の水素イオン濃度と比表面張力と の關係を賽驗的に求め之より界面活性度の順位を決定し, 同氏及勝亦君雄 氏(同誌 8, 1040) は措種のアミ) 酸の水溶液中に於ける骨炭への吸着量 と水素イオン箼度との關係を實驗的に求め文其吸着度の順位は前報に於け る界面活性度の順位と一致する事索觀察せり。竹內時男氏（東工學報 1 , 101) は毛細管內の水銀と水銀鹽溶液間の界面張力を理論的に取扱ひ, 岡小 天氏（數物 III, 14,233） は稀薄なる强電解溶液の表面張力をデバイ・ヒ ェッケル氏理論の立場より論じ表面張力と浱度との關係が實驗的事實とよく 一致する事を示せり。本多顯矅氏（九鑛 3,252）は炭素2.31〜4.58\% を含 有する熔融せる鐵の表面張力を測定し其溫度係數が正なる事を認的たり。 林不二男氏 (Biochem. 16,1) は炭末の結類吸着に及䄈す水素イオン濃度, 並に種々の添加物の影響を檢し, 北川徹三氏（物理化學 6,106）は觸媒に 用ふる還元銅への水素の吸收速度, 吸着量及び吸收量を測定しワード氏の 理諭と一致する絬果を得たり。石川房吉氏（北海醫 10，302）は羊皮紙を 隔て」行はる」血炭への醋酸吸着に於て吸着量と濃度とが正比例する事を 見出它り。

膠質 田中隆吉氏 (本誌 35，349）は連續洗涤に依るコンゴー酸ゾルの 形成並にゾルの濃度と洗涤液の電氣傅導度との間の定量的關係を實驗的に 定め, 又滤過速度及粘度を测定して解膠現像はコンゴー酸沈澱粒子の極大 膨潤の直後几起る事を倠め, 次で（本誌 $35,354,357$ ) 該ゾル几中性監を 加ふる時赤色飞變ずるは中性監のゾル分散度向上作用の結果をる事を明か にし, 又(本誌 35, 1363) 該ゾルを加熱する際赤色に變じて分散度の增大 するを認め且っ其眚大の程度は最初のゾルの濃度小なる程大なる事を見出 せり。河村治郎, 田中國吉兩氏 (本誌 35,544,549) は四監化炭素, 炭化 
水素等のゴム膠質溶液の粘度を測定し之にアセトン，アルコール等のゴム 沈測劑を加ふれ代比粘度低下するも溫度の上早と共に增大する傾向あるを 觀察しててれに說明を與へ, 桂井富之助氏（Bull. C.S.J.7，257）は八ロ ゲン化銀ジル及三硫化砒素ゾルを加埾釜中に於て $160 \sim 200^{\circ} \mathrm{C}$ 亿加熱し各 ゾルの加熱に對する安定度を試驗し, 橋本四郎氏(東京商工獎勵館報告 21 , 1) は鋪道用瀝青乳劑の製造研究をなし粉末石畧僉 $1.5 \mathrm{~kg}$, 布海苔 $30 \mathrm{~g}$, 硫化 ソーダ $5 \mathrm{~g}$, アスファルト $500 \mathrm{~kg}$, 珪酸ソーダ $1 \mathrm{~kg}$, リモナイト $350 \mathrm{~g}$, 水

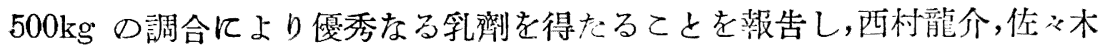
保兩氏 (大工試 12,19 號 1) はオルトクロマチック臭化銀乳扸の製法に關 し研究し優良なる感色性及保存能力を有する乾板の製造に成功し, 西田謹 次, 中村眞三兩氏（大工試 13，1. 號 1) は市販の種々の竄這用印畫試乳 劑を分析し且濃度曲線を作製せり。楖川鐵之助, 西时義郎兩氏 (大工.試 12 , 16 號 1 ) は細寒天試料 37 種に就普通成分の分析及吸水度, 溶僻速度, 溶 液の粘度, 凝固能力, ヂェリーの强度等老實测比較し寒天の品質判定の合 理的試驗法の一助となし, 白演潔氏（農化 8,659）は寒天を水とともに加 壓釜內に $130^{\circ} \mathrm{C}$ に加熱して得をる2 物質を種々の條件の下にて無機酸を 以て分解し分解の狀況，生成物の檢查を嗳し寒天の構造老推定せり。志方 谷三, 福渡七郎兩氏 (本誌 35,42 ) は $17 〜 20^{\circ} \mathrm{C}$ に於て種火の無機物ジ に周波數 $60,10000 \mathrm{~V}$ の交流を加ふればジルの沈澱が促進せられ又ゼラチ ン水溶液が同樣の交番電場几於て粘度大となり脫水作用を促されて水和作 朋の進行阻止せらる」事を觀察し, 西健, 福渡七郎兩氏 (理研報 11, 1201) はツンドラ膠質系に交流を加一周波數, 含有水分量及媒質を變へて透電恒 数を測定し，その結果より水の形態を固着水，粘着水，自由水の 3 者几分 類し得可をを見出し，低周波に於ける透電恒數の增大が粘着水に起因する と結論せり。一瀨雷信氏 (日化 53,17) は金屬析出電位に對するゼラチン 
の影響をポーラログラフを用ひて測定し，ゼラチンが極金屬の活率を減ゼ 極面の電氣抵抗を增すてと並にゼラチンが不純物として混入せるイオン及 作用イオンと錯化合物を作ることを見出せり。筒井彥彌氏 (Biochem. 15, 163）以金ゾルに種くの非電解質及食監液を添加し之の㠜固に及济す影響 を檢し, 堀場信吉, 小田切瑞穗, 淸田進氏等（特訢公告 No. 1964）は監 類オルガノゾルの製造法を發明せり。駒形作次氏（電會 52, 231）は電場 に置かれたる場合に複屈折を篇すが如きゾルの電氣抵抗, 透電恒數の值は 加一られたる電場の方向並に電壓の大さにより左右せらる〉事を觀察しそ

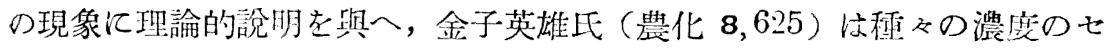
リシン溶液を以てベンゾール, 四監化炭素, クロロフォルム, 蛹油, オリー

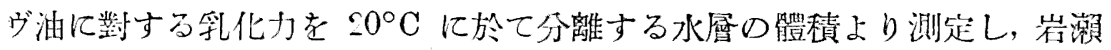
柴一氏 (SC. P. 17，68) はワイルマン氏金ゾルの安定度と水素イオン泎度 との間の關係老賔驗的几觀察せり。井上柳梧, 北澤孝一兩氏（篓絲 4,69） は天然絹綵に於ける各種精練工程がフォブロインの膠賢化學的性管に及添 す影響を檢する䉆にフィブロインソルル精練に際して使用忠らる」種くの 蔡品を加一其比粘庭の變化を檢討世り。

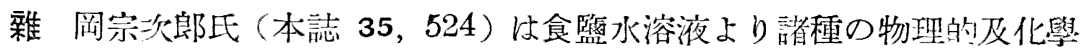
的影響の下に食監の絬晶を生ざしめ之を肉眼, 顯微鏡及熱天科等にて檢查 し，不透明性は微細なる結晶間に含付世らる」母液に起因す方事在明かに し, 絬晶生成及成長の機構几諭及し，同氏（本誌 35,935 ) は又數種の空 素肥料の吸濕性を此较し，硫酸アンモニウムの比校的吸濕性小なる事を認

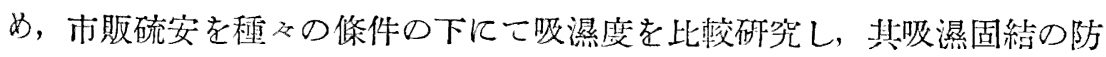
止法を述へ，青野武雄氏(本誌 35，1093）は皮獏の瓦斯透過速度を簢單迅 速に测定する簡易测定器を考案し, 之を用ひて種くの包裝用紙の防濕力を 測定比較せり。艇非三郎氏 (本誌 $35 ， 142$ ) は C. G. S. 單位の涂度表を作 
䡛し乾燥空氮に關する諸種の變化を容易に決定するととを得, 同氏及後原

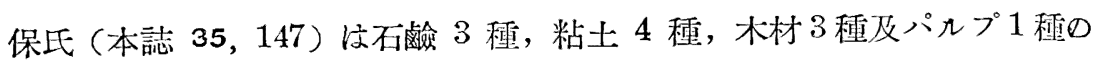
本衡水分を測定し吸濕等溫線を作製し，山本健磨氏(理确報 11, 1083)は 36 種の陽インンに就て監化アンモニウム結晶の成長に淽する影響を調査 し，東恒人氏(䧉研報 11,1062 ) は三苗圖表にて有機化合物の百分率を圖 示するに當り，附加反應或は除去反應の生成物の示成點の位置的關係を数 量的に檢討し, 之を應用して石炭變成に件ふ心化學變化を考察し, 又(理研報 11，1266）化合物の示成點と分子量との間の圖形的位䁂關係を調べ其應用 として物筫の種族及分子量より示成點, 分子式, 元素百分率を求光る法, 化學反應に際して化合比を定むる法を述べたり。村上永治氏（Bull. C. S. $J .7,216)$ は加熱曲線の作製, 密度及屈折率の测定の絬果より液態に於 けるニトロベンゾール及二硫化岑素の 2 種の變態の存在を否定し, 柳沼得 三, 新井玄馬, 早川堅太郎氏等 (P. I. A. 8, 91) は牛の脊监より抽出せ

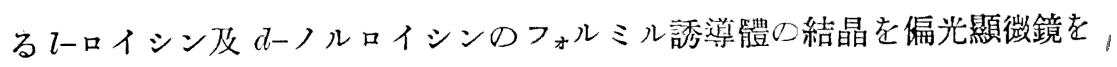
以て觀察せり。小林久本, 山本研一, 阿部二郎氏等（本誌 35, 70) は棕櫊 油のカロチンの酸性白土に依る呈色反應を種々の溶媒中に於て試驗せり。 岡本勇象氏（九工菓 7，80）は空氮と既知量炭酸瓦斯との混合氣中の炭酸 瓦斯含有量より室氣の流量を求めオリフィスの流量係數を計算せり。佐队 木一権氏 (東工試 27，3 號 25) は空素, 酸素及アムモニア上りなる可燃

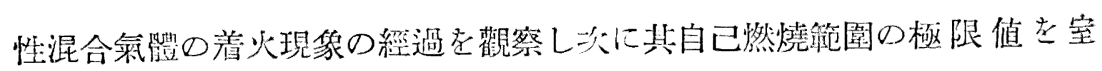
溫，大氣壓下及減壓下において上向焰と下向熖とに闗して探索しその結果

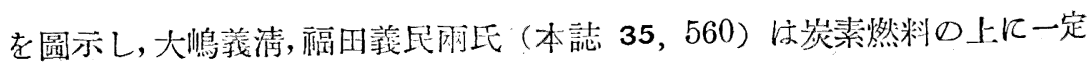
速度を以て空氣流を通過耴し只溫度を次第几上昇吼し的て然燒減量を連續 的に测定しその着火行程在攻究し又 (本誌 35, 566) 炭秦の着火溫度は空氣 の流率に無關係后る特數度る在知り，份（本誌 35，570）炭素然料の灰分 
の着火溫度に對する影響を檢討してその着火行程中に於ける任務を推論せ り。神原周, 松井元太郎兩氏 (本誌 35，453) は白金抵抗寒暖計の使用に 必要なる恒数を泛定せ几篇如液體酸素の沸點, 固體炭酸瓦斯の昇華點, 水 銀の融點在测定せり。

\section{4. 無 蟣 化 學}

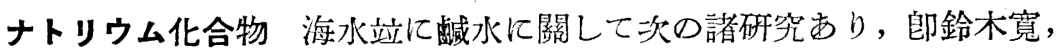
坂場博兩氏 (專研報 35, 1-20) 治海水に關する研究（第 2 報）に於て海

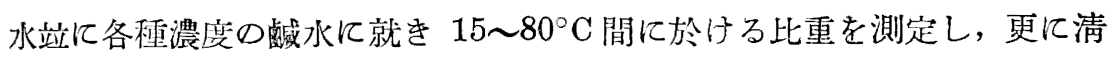
水和雄氏を加へて第 3 報（專研報 41, 1-35）に於て海水の濃縮率及蒸發 率の測定を行ひ比重と濃縮率との間に成立する資驗式を求めたり。藤貫清， 浦山貞雄爾氏 (專研報 36，1-23) 以战水の理化學的性質に關する研究（第

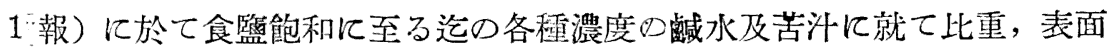
張力, 粘度係數, 比熱及電氣抵抗, 傳導度等を測定し, 秋本信吉氏 (專研報 36，25-49）は之の第 2 報に於て比重と含有成分との關係, 例へば各種態 の㲜素, 鐵, 苦土, 加里, 石灰, 珪酸, 樊土, 臭菜, 鹽素等との關係を明

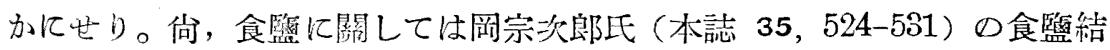
晶の不透明性に就ての研究市り, 顯微鏡, 蓺天科等に依りて檢查の結果, 白色不透朋の結晶々單一なる結晶にあら亦して此を構成する透朋なる微結 晶間に合まる〉母液の䉆に不透明となるを知れり。また奧野俊郎, 宮崎兄 一兩氏 (本誌 35, 328-332) は $25^{\circ} \mathrm{C}$ 亿於て $\mathrm{Na}_{2} \mathrm{SO}_{4}-\mathrm{H}_{2} \mathrm{SO}_{4}-\mathrm{H}_{2} \mathrm{O}$ 系の本

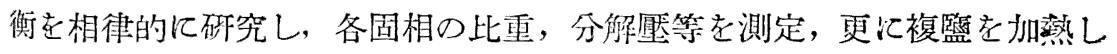
分解の際の結晶構造の變化応 X-線に依りて試驗發表せり。後者の加熱分 解几就ては别府次郎氏（九工急 7, 101-109）を加一更に詳報を出せり。此 他, 石川總雄, 益田菬良, 萩濢浩氏等 (理研報 11, 1244-1253) の奘天科 


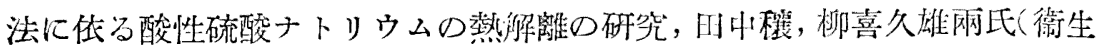
試報 40,243-258)の硫化ソーダ製造試驗成就待の發表あり。後者は文獻に 記載出られたる方法の追試なり。

マグネシウム化合物 苦汁の利用法に就ては加藤虎郎氏の引續きの研究

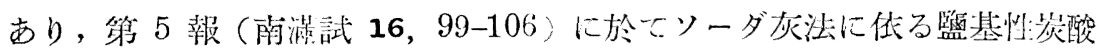

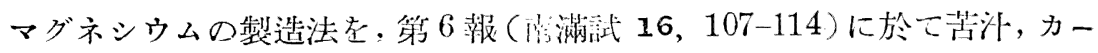
ナライト探集後の母液より二酸化マンガン及硫酸を用ふる臭素の採集法を 研究發表せり。臭素在定量的に蒸溜するには硫酸の浱度は 5\%( vol) 程度 と䉆すを可とし二酸化マンガンは處要硫酸の約 $1 / 10$ 卡適當とすとの争な り。佮苦汁の一新利用法として此を原料とするマグネシア七メントの㱔造

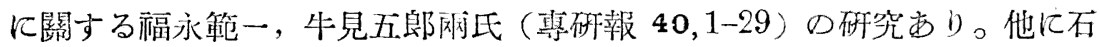
川總雄，佐野幸吉网氏(日化 53,703-707) の酸化マグネシウムに低る水蒸 氣の吸着汇就ての研究疑告も見えたり。

カルシウム化合物 松井元太郎, 尾藤堅, 青山勃造氏繁 (本誌 35,553 ; 東工學報 1，239-246）は炭酸カルシウムの炭酸ガス氣流中の加熟變化（第 2 報) に於て氷洲石の第一及第二分解點の測定をなし，田炕節郎，監見賢 吾, 安達正明氏等は無機化合物の解離壓の新测定（第 1 報）(日化 53, 329-341) に於てテルマノワーゲをる特殊の测壓熟天科を用ひて炭酸カル シウムの熱假離平衡の测定を行ひたり。從來の测定値が非常に區及なるは

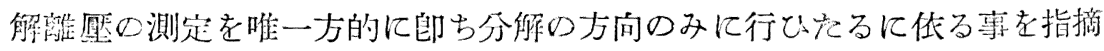
して反應の网方向より测定をなし其平衡値を求めたり。企く同一方法にて 时炕, 監見网氏 (日化 53, 1169-1172) は水酸化カルシリムに就ても解離壓 平衡を测定せり。佮水酸化カルシウムに就ては野田稻吉, 三好晃兩氏(本誌 35，799-804）の石灰の反應恻に關する研究（第 1 郝）に於ける水酸化力 ルシウム水溶液の電導度测定の報告; 杉野喜一郎, 立水健吉, 藤野茂氏等 
（電化 51，9-10）の消石灰の大なる結晶の製法及その絬晶の光學恒數に關 する報告等西り。石灰耋素の冷浸出液 $\left[\mathrm{Ca}\left(\mathrm{HCN}_{2}\right)_{2}\right.$ 老含む $] 30 \sim 40^{\circ} \mathrm{C}$ に数日間保てば六獬の大なる消石灰の結晶を析出すとのととなり。又小栗 捨藏, 水科元安, 井上幸彥氏等は乾燥劑としての監籃化カルシウムの效率に 就ての研笙をなし，青野武崔氏（Bull. C.S.J. 7, 143-154,247-256, 274- 。 280，287-297）はカルシウムカーバイドの穻素添加及その速度への種々な る影響, 即ち窒素の壓力, 作用時の溫度, 粒の大さ, 接觸劑等の影響を檢 し笨3〜6 報炕眆りて報告する處むり。

バリウム化合物 向井參之允氏 (九工櫓 7，30-44，130-136） は本年も 重晶石の利朋を日的をする研究を續行し重晶石を還元して得らるつ硫化バ リウムの脫硫方法に就き攻究, 其 1 亿硫化バリウムを水溶液に於て他の金 屬酸化物と處理し梲硫して水酸化バリウムに戀ぜしめ生ざたる他金屬硫化 物は燒きて再び酸化物として利用する方法, 其 2 亿第二鐵イオンに依り硫 黄及バリウム覧類索製造する方法を完成したり。この成績は鹽化鐵及硝酸 鐵を以てバリウム 100\%, 硫黄 $90 \%$ 程度に達し得たりと, 向同氏（九工 彙 6，272-282) は硫化バリウムの水溶液を 八ロゲン及過酸化音素にて酸 化しハロがン化バリウム或は确酸バリウム及硫橫を製造せんとする研究る 行ひたり。

アルミニウム化合物 田中弘氏は引纉き各種原料よりアルミナ製造の方

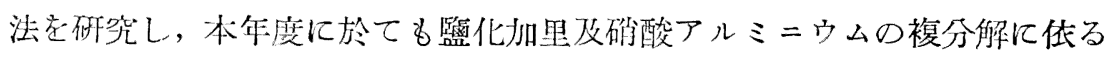
硝酸加里及アルミナの新製造法 (第 5-6 報) (東工試 27, (7) 1-12, 12-32) の發表あり。粘土より硝酸アルミニウムの製造試驗に於て焙焼し細粉とな せる粘土に $6.923 \mathrm{~N}$ の硝酸を作用せしめて平均 $85 \%$ のアルミナ收率を 得たりと, 更に複分解に位る硝酸加里製造賽驗に於ては先に報じをる相律 的研究結果の指示与る最適條件の下儿於て行ふ事儿依り最も良好なる收率 
を擧ぐる事を實談し得をり。臺灣尘明格石の利朋法に就ても內田潇一氏 （臺督研工報 72，1-30）の引續きの政㭝あり明學石よりなるプラスターの 應用試驗とプラスター凝固物の化學的組成の研究なり。

マンガン化合物 二酸化マンガンの製法と乾電池用二酸化マンガンに就 ての研究にして, 䑶山直人, 飯田廣兩氏 (本誌 35, 907-913,913-915) の研 究は交流電解に依る二酸化マンガンの製造法に於ける適當なる條件を求め 電解反應機構に就て論じたるるのと交流電佩法に依りて密度大にして力强 き乾電池用二酸化マンガンを得たりとの報告なり。牧野三郎氏（本誌 35 , 174-177) のものは乾電池用二酸化マンガンの研究（第 3 報）:各種天然座 二酸化マンガンの加熱變化と電氣的特性に關する報告なり。

タングステン化合物 伊藤向氏（日鑛 48，854-861） は錫精鑛中に相當 量のタングステンを含有する事を知り, 此を壓力罐中にて菏性ソーダの溶 液と共に加壓, 加熱しタングステン酸ソーダとなし抽出する方法を試驗し たり。飯高一郎, 青木康造网氏 (Bull. C.S.J.7, 108-114) はタングステ ンカーバイドの生成と其分離法を攻究し, 從來のタングステンカーバイド は $\mathrm{W}, \mathrm{WC}, \mathrm{W}_{2} \mathrm{C}, \mathrm{C}$ 等の混合物なるが純粹なる $\mathrm{WC}$ をフェロタングステ ン（又は W) と炭素より作り，監素との反應狀況を精䄳せる結果，混合物 中よりWCを定量的に分離せしむる方法を見出したりと，少各種のタング ステン酸監溶液の電品電導度に關するものに䇥原俊郎氏 (マツダ 7, 113122）の硎究西り。

覧素及監素化合物 中村隆壽, 江田靜男, 潮初一氏等（本誌 35, 11351140，1140-1145）は液體鹽素を用ふる漂白液研究（第 1-2 報）漂白液製 造（其 1-2）に於てパルプ漂白用漂白液の工業的彆造察驗として石灰乳に 直接監素ガスを吹达む方法と循環ポンプにより石灰乳を趔流せしむる中途 に於て吹达む方法とを試み其操作の最適條件を求め，更に酔粉に依る漂白 
試驗と比校して其漂白能力に大差なく使用上本法の優るととを說述せり。 丈, 石川總雄, 萩澤浩, 室岡豊作氏等（理研報 11, 284-296, 297-303,

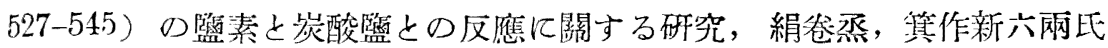
๑エチレンと監素間の反應に關する研究等あり, 共に反應速度圭主眼とす るものなり。

吸着劑 酸性白土に關しては田中芳雄, 桑田勉, 古田迪氏等（本誌 35, 649-656）の酸性白土類の吸着作用（第 2 報）水溶液中上り色素の吸着竝 几其機構理論, 山本研一正（本誌 35，1218-1224）の酸性白上の物理化 學的性筫（第 6 報）酸性白土の X-線研究（其 2 ）等の報告を見, 活性炭 に關しては勝田泰, 岡部政藏兩氏（衛生試報 40，161-179）の活性炭の效 力檢定法涉飞製造法 (第 1 報)，木付清三氏（日化 53，497-503，777-782） の活性炭素の接觸作用（第 3 報）鎻狀テルペンアルコール化合物传對する 活性炭素の接觸作用几就て（第 4 報），チトラール及チトロネラールに對 する活性炭素の接觸作用几就て, 林不二男氏（Biochem. 16，1-15）の炭 末による糖類の吸着等の報告あり。更にシリカゲルに關しては鲛島實三郎 氏 (Bull. C.S. J. 7，133-135) のシリカゲルに依る瓦斯の收着に就ての 研究あり。アムモニア，炭酸ガス，エチレン等の收着量を筫测せり。

ガス類 ガスの液唱に對する溶解に關しては宮本進, 加屋哲夫爾氏(廣理 報 2, 59-72) の酸素の水に於ける溶解速度に就て (第5 4 報)酸素の亞硫酸 ソーダ溶液に於ける吸收速度及河村交一氏（日化 53，783-787）のオジ ンの研究（第 1 報）オジンの水站に稀硫酸に對する溶解度等の研究あり。 オッンは水並に稀硫酸に於てはいづれも其溶解度はヘンリーの法則に從ふ

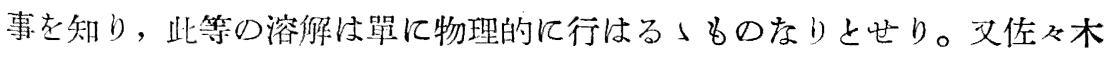
一雄氏（東工試 27，(3) 25-41）のアムモニアガスの自己燃燒性に關する 研究あり, アムモ二ア酸化操作中起り得べ委爆發の防止几資世んとするも 
のなり。佾吉村倫之助氏 (本誌 35，293-300，300-306; 旅工钺 22，1-14)

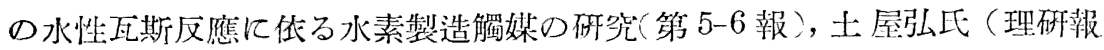
11，1136-1149）の一酸化炭素の接觸的分解（第 5 報）等の引續ける研坒 報告あり，共に表題に示す如く㯰媒を主として取扱へるものなり。

雜 製造方面に關卞る研究には炏のbのあり。小山神氏（東工試 27， （4）1-17）はクロム鎪に適當なる高溫に於て監素ガスを作朋せしめて監化 クロムを作り之より各種クロム化合物を製する研究老第し, 大汇辰雄氏

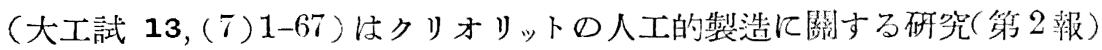
に於て弗化ナトリウムよりアルミン酸ソーダ法站に硫酸アルミニウム法に 依りて氷晶石を生成せしむるに當りその生成率站に組成に及ぼす種《なる 影響に就き實驗し，斯くして得たる人造氷晶石と天然の夫れとに就き性質 の差異に就き比較實驗老行へり。·河田五郎市氏（衞生試報 38，99-106; 40，149-159）は過酸化物の製造試驗成績（第 1-2 報）に於て過酸化水素 を用ふる過酸化マグネシア, 過酸化亞鉛, 证に過酸化不灰, 過酸化ストロ ンチウム等の製造試驗を受し其結果を報告したり。侣他に濃厚過酸化水素

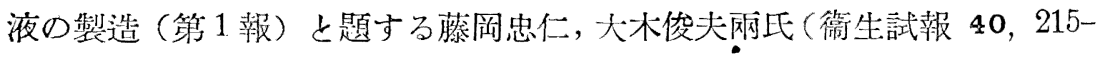
236）の報告むり。過酸化水素の工業的諸製造法を調查批籼圵るものなり。 化學變化，性質方面に關する研究には先づ種くなる反應を取扱へるもの に尾藤堅, 青山幸造, 松井元太郎氏等（本誌 35, 559-560）の确酸荅鉛の 乾燥空氣尺流中の加熱變化, 田丸節郎, 櫻牛春雄网氏 (日化 53, 852-861) の酸化ストロンチウムと錫とより錫酸監を生成する接觸反應, 啝藤正一郎 氏(理研報 11，593-E99，600-605) の電壓滴定に依る化學反應の研究（第 4 報) フェロシアン化リチウムと亞鉛との反應, (第 5 報) 亞鉛とフェロシア

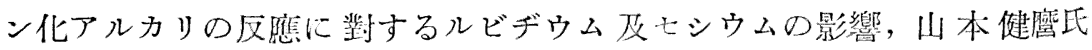
（理研報 11，1083-1097）の絬晶の生長（籘3 報),監化アムモニウムの䋨 
晶の成長に及ぼす金碭イオンの影響，桂井富之助氏（Bull. C.S.J. 7, 374-375)の $100^{\prime} \mathrm{C}$ 以上に於ける監化鐵の加水分解に及症す監化ナトリウ ム, 監化バリウム，監化アルミニウム等の影響，秋本千秋氏（鞍山鐵 43, 309-325)の汽缶雚用水軟化法に就て一石灰ゼオライト軟水豇驗站に還元用食 監廢液より食監の殴收等數多》嘏告あり。又各種物理化學的數值つ测定を 篇せる \&のに石川總雄, 森一郎, 室岡豐作氏等（日化 53，181-189）の臭 化カドミウム, エチルアルコール系の研究, 石川總雄, 立木健吉网氏（日 化 53，551-558）の臭化ナトリウム及臭化カリウムに關する熱力學的研究 一乙の丽者は非水溶液電池の應用に低りて溶解度, 轉移點, 蒸氣壓その他 熱力學的數值を测定せるものなり一更と田丸節郎, 監見賢吾网氏( 日化 53， 647-649)の先の岑酸カルシウムに於けると同樣なるテルマノワーゲに依る 炭酸ストロンチウムの攀解離本衡の测定, 松井元太郎, 神原周兩氏 (本誌 35，788-794）の膨脹計による含水監類轉移點の精密測定, その實例とし て同氏等及吉野時方氏（本誌 35，794-799）の $\mathrm{Na}_{2} \mathrm{CO}_{3} \cdot 10 \mathrm{H}_{2} \mathrm{O} \rightarrow \mathrm{Na}_{2} \mathrm{CO}_{3}$ ・ $7 \mathrm{H}_{2} \mathrm{O}$ 轉移點の测定，佐川達四郎氏(金屬 9，189-196)の四監化チタンの 比重及粘度係數, 小川英次郎比 (Bull. C.S.J. 7，265-273; 儿工菓 7, 14-29)の七二酸化レニウムの蒸氣厴灭八二酸化レニウムの蒸氣壓, 僻離壓 等の堛告を見なり。

\section{5. 有機化學}

物理的性犋 東恒人氏(理研報 10，495-503；11，1062-1071，1255-1266) は三何坐標を用ひて有機化合物の百分率を圖示する方法を定め，之により て分子式或は百分率を簡單に求め得らる」こと示し, 次で附加及除去反 應による三角坐楅示成點の位置的變化に就て論じ, 佮其他 2,3 の應用を 記述せり。藤田安二氏 (日化 53，871-879） は環式炭化水素其他に就て稌 
中に於ける二重結合或はヒドロキシル基等の位置が沸點に及壮す影響に關 して諭じ，小田良平，野間元誠次网氏(本誌 35，1357-1363)はオ トト・・ シュミットが熱分解に關して提出せる二重結合の法則, 郎ち二重結合に近接 せる品一結合の交互强弱說を更に演張し，二重絬合が２個以上存在する場 合等に就ても各種の實例を舉げて其適用性を論じたり。

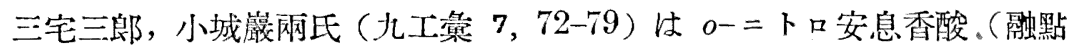

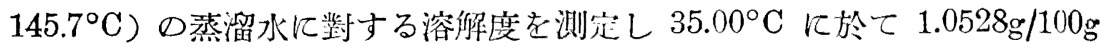
なる結果を得，又同物質の固態並に飽和水溶液に就き其比重を精密に测定 せり。青山新次郎, 时代長司网氏（藥學 52, 977-978）は $p$-ニト・フェ

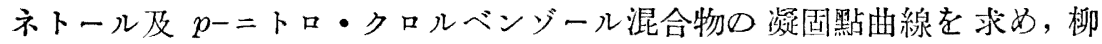
沼得三, 早川堅太郎兩氏 (本誌 35，365-370）はアニリン，モノェチルア シリン及ヂェチルアニリンの 3 者に就き 2 成分系及 3 成分系の平衡を 研究して混合系の融點を測定し, 山口四郎氏（日化 53，964-966) は $p$-チ クロル・ベンゾールより製したる純粹なる 2.5 -ヂクロル・ニトロベンゾー ル(補正融點 $\left.54.48^{\circ} \mathrm{C}\right)$ の沸點を測定し $261.15^{\circ} \mathrm{C}(756.46 \mathrm{~mm})$, 換算して $261.48^{\circ} \mathrm{C}(760.00 \mathrm{~mm})$ を得たり。

還元（1）水素添加 小松茂, 三井啓策网氏（京理紀 A， 14，297-301） は安息香酸ェチルェステルのアルコール溶液に於ける水素添加に就て研究 し，此際溶桇は何等の影響を及匢さざるとと，並に安息香酸は其ェチルェ ステルの形に於て定量的に水素添加店し得ることを確めたり。安東新午氏 (本誌 35，1119-1123)は引續きフェ)ールの水素添加に關して研究し(本誌 35，262 參照）還尼ニッケルを觸媒上しフェノール 1 分子に對し水素 3 分 子の割合にて加㕓の下に $360^{\circ} \mathrm{C}$ に熱する時は, チクロへキサノルを經て チクロヘキサノンに至る反應系統と, チクロへキサノルよりチクロへキセ ン，チクロへキサンを經てベンゾールに至る反應系統の行はる」てと䓘認 
め，且チクロヘキサノルよりチクロへキセンを生成するにはニッケルは不 適當にしてアルミナが良好なる䆉媒なりと述べたり。木村作治郎氏（日化 52，447-456) はヒドロナフタリン類の吸收スペクトル，接觸還元其他の結 果に基き其等の構造に就て論じたり。

（2）電解還元 無水フタール酸は純化學的還元によれば種ふなる還元生

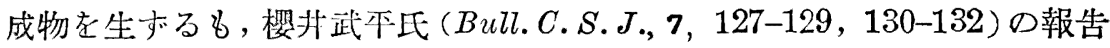
せる電解還元に於ては唯フタリド $\mathrm{C}_{6} \mathrm{H}_{4} \backslash \mathrm{CH}_{2}>\mathrm{O}$ のみが得られたり。志方 益三，保崎信成兩氏(京農紀 17, 1-19) はポーラログラフを用ひて 2.4 $(\alpha)$ -, $2.6(\beta)$-及 $2.5(\gamma)$-ヂニトロ・フェノールの電解還元壓を测定し, 此等 3 種ヂニト口化合物の被還元性は第一段に於ては $\gamma>\beta>\alpha$, 第二段に於て は $\beta>\alpha>\gamma$ なるととを見出し, 又ポーラログラフ法により 3 䅜デニト 口化合物の水に對寸る溶解度 $\left(25^{\circ} \mathrm{C}\right)$ を測定せり。志方縊三, 舘勇兩氏 （京農紀 17，45-55）以又上記と同椂にしてアジベンゾールの還元壓をも测 定せ门。

酸化 下瀨林太氏（理研報 11，510-514）は同氏從來の研究結果に基き 揮發油の接触酸化によるマレイン酸の工業的製造を試み筫驗室に於けると 略近似せる收量を得たりと報告せり。井上春成，堀口博兩氏は $\alpha$ トロ・ ナフタリンの接觸酸化によりフタールイミドを製するグリーンの方法に就 て檢查し, 此際触媒として酸化ヴっナヂウムは酸化モリブデンよりる良好 にして反應溫度 $350^{\circ} \mathrm{C}$ に於てフタールイミドの收卒 $50 \%$ 以上に及ぶてと を報告せり。吉町貞一, 浦田晋吾网氏 (北工試 37，1-39) は杉其他の木材 によりアルコール中にアルデヒドの生成するは材材質中に存するアルデヒ ド基丈はケトン基による酸素活性化に基くるのと述べたり。

横山盛暗, 山本一夫兩氏 (Bull. $C . S . J .7,28-34$ ) はピリヂンの稀硫 酸溶液を陽極液として電解酸化し生成物を檢したる結果, 先づ第一段に於 
てフォルムアルデヒド，アムモニア及メチルアミンを生じ此等が二次的に 變化して蠸酸,硝酸,ヂメチルアミン等となるものと報告せり。横山盛彰氏 (Bull. C. S. J. 7，69-72) はピコリン在同樣に電解酸化し大量のピコリ ン酸と少量の蟻酸, 醋酸, アムモニア, 硝酸, $\mathrm{CO}, \mathrm{CO}$ 等の生成を認め, ピコリン酸も亦同楾の條件にて酸化され蟻酸, アムモ デヒド及後 2 者い二次的に縮合せるメチルアミン類を生ずるととを知りた り。橫山氏（Bull. C.S.J.7，103-108）は更に=コチンを同樣にして酸 化し生成物より蟻酸, マロン酸, ニコチン酸, オキシニコチン, メチルア ミン， $\mathrm{CO}_{2}, \mathrm{CO}$ 及蓚酸と思惟せらる১ものの少量を喗離せり。松田亮一

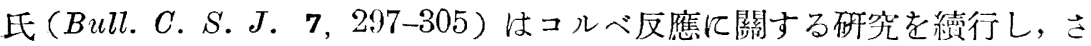
きに醋酸カリウム溶液電解の際エタンの發生するは過酸化アセチル $\mathrm{CH}_{3}$ $\mathrm{COOOH}$ の中間生成によるものと推定せるが, 更にプロピオン酸カリウム の電解に就て試驗しェチレン及過酸化水素の生成するととにより同樣過酸 化プロピオニル $\mathrm{C}_{2} \mathrm{H}_{5} \mathrm{COOOH}$ の中間生成を合理的なりと涊めたり。

ニトロ化合物 久保田桐造氏(日化 53，404-409，409-417，1064-1084) はクロルベンゾールのニトロ置換に就て研究し先づウルマンの方法により 2・6-ヂニトロ・フェノール上 $p$-トルオール・スルフォクロリドとをヂェチル アニリンの存在に於て作用せしめてェステルを製し，後之を水蒸氣蒸溜又 は濃硫酸にて分解し 2.6-ヂニトロ・クロルベンゾール（收率 75\%）を得た

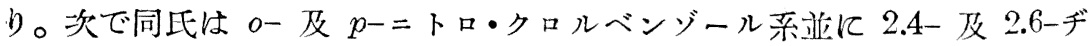
ニトロ・クロルベンゾール系の融點曲線を求め, 更にクロルベンゾールのヂ ニトロ置換の際 2.6-ヂニトロ・クロルベンゾール（融點 $87.5^{\circ} \mathrm{C}$ ) の生成を 確認し且之が生成條件としてはモノニト口置撸の階梯に於て溫度稍高く, 硫酸使用量大なる時比較的多量にして全ヂニトロ化合物の $5 〜 6 \%$ ス及゙ 文文獻の如く $10 \%$ 以上には決して達せざりしてとを報告せり。水田政吉 
氏（本誌 35，1276-1280）は臺灣出磺坑原油揮發油溜分中に含俏せらる」 芳香族炭化水素利用の豫供實驗として㜈め 30 〜 95\% のトルオールを含有 せしめたる挥發油に就きモノニトロ・トルオール及デニトロ・トルオールの 製造試驗を行ひたるが，石油炭化水素共存量の如何に關せ和好成續の得ら るってと京認めたり。

ハロゲン化合物 加藤七チ氏（理研報 11，765-768）はトラン及スチル ベンの光化學的臭素置換に就て研究せり。而して是等の場合最子要通にト ランよりはシス化侖物, スチルベンよりはトランス化合物を生ずるも, 溶 劑在適當に選定する時，師トランの阿監化炭素溶液にて直接臭絜置換すれ ばトランス型ヂブロム・トランを生じヌスチルベンのメチルアルコール溶 液にて息素置換すればシス型ヂブロム・スチルベンの生成するてとを見出 Lたり。

ヂアン゙化合物 山本永之助氏（本誌 35，15-20）泣同氏既報の方法によ りメダル酸, スルファニル酸亚に $m$ ーニトローpートルイヂンより坐吉るヂ アゾニウム監の水溶液中に於ける分解速度を测定し, 又山本氏は五息類治， 旸島二郎网氏と共同にて(本誌 35，767-773，1407-1413) o-クロルア=リ

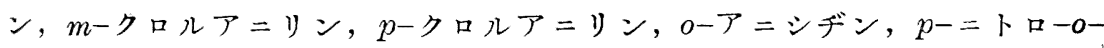

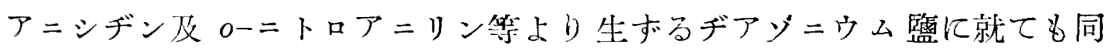
樣にして分佷速度を测定出り。

櫻井季雄氏（理研報 11, 711-7:28) はヂアミノ・ヂフェニル類のテトラゾ 化合物と 2-ナフトールー6.8-ヂスルフォン酸 ( $G$ 酸) と老酸性にて作用せし むる場合の生成物に就て研究し，テトラゾ・ベンジヂンとG 酸とより生ず る赤色爆發性結晶の構造は下記（I）の如きシン型ヂアゾスルフォ・ヒドロ

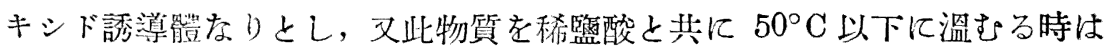
黄色のアンチ型（II）に變ボるとをを報告せり。 


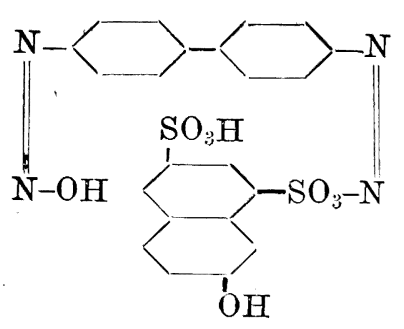

(I)

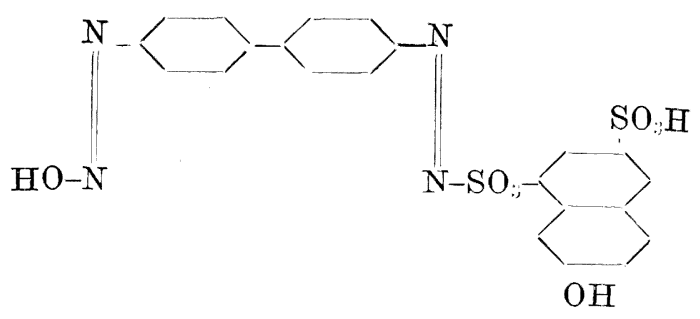

(II)

縮合 鈴木庸生, 堀汇忠一兩氏（理研報 11, 383-385）はアセトンとア ムモニアよりヂアセトンアミンを製する際反應促進劑として無水亞硫酸, 亞硝酸アムモニウム, 㗂酸アムモニウム, 硫青酸カリウム, 硫青酸アムモ ニウム, 氷醋酸等を何れも可及的脫水して用しる時は頗る有效なるととを 報告せり。妻木德一氏（日化 53，8-13；Bull. C. S. J. 7，45-50）は 1.2 ーヂフ ニルー3.5-デケト・ピラゾリヂン（III）にアルデヒド類を作用ษしめ 種くなる有色縮合䶣 (IV 型)を得たり。

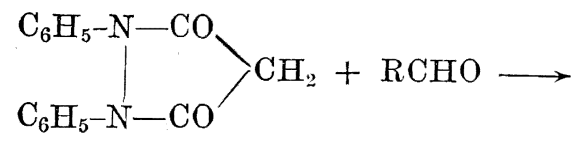

(III)

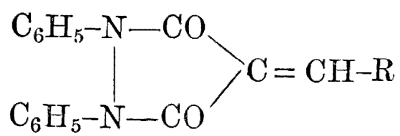

(IV)

富田眞雄氏(藥學 52，429-433，900-903) は銅粉及醋酸銅の存在に於て カテコール・カリウムと oーヂブロム・ベンゾールとを 190～200ㄷㄴ熱す るか或は フェニレン・ヂオキシド（融點 $119^{\circ} \mathrm{C}$ ) を製したり。之を同榢にして m-ブ ロムーp-クレゾール・カリウムの 2 分子縮合によりヂトリレン・ヂオキシド (融點 $116^{\circ} \mathrm{C}$ ) を合成し丈 1 -ブロム-2-オキシ・ナフタリンのカリウム監よ り微量の 1.2-ヂナフチレン・ヂオキシド（分解點 125ㄷ）它得, 更に 2.3ヂオキシ・ナフタリンー6ースルフォン酸ナトリウムを稀硫酸と封管中に熱し 
て 2.3ーヂオキシ・ナフタリンの外に 2.3-ヂナフチレン・ヂオキシド（融點 $300^{\circ} \mathrm{C}$ 以上）老得をり。

チフェニル㮇導體 佐古眞一氏（九工紀 6，263-306）は 2.2'-ヂアミノ・ ヂフ $x_{x}$ ル或は其同族體に就き $o$-ヂアミノ・ベンジール類の反應性と比較 するため各稴のヂフェニミヂン型環化物質 ( $\mathrm{V}$ 型) を製したり。又此等ヂ $7_{x}$ ニミヂン型化合物を活性物質に分割せんとの試みは成功せざりしも， $l-6.6^{\prime}$-ヂアミノ-2.2'-ヂトリルより出發して活性ヂフェニミヂン誘導體を得 たり。

( V)

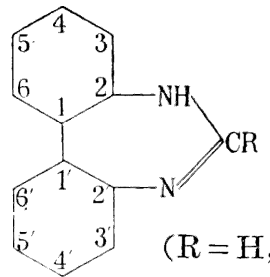

, $\mathrm{CH}_{3}$ 又は $\mathrm{C}_{6} \mathrm{H}_{5}$ )
(VI)

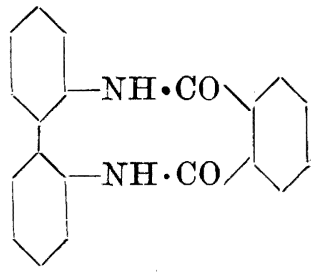

佐古氏（九工紀 6，307-325）は叉 2.2'-ヂアミノ・ヂフェニルと無水フタ ール酸とり縮合生成物の構造に就て論じこれを對稃型モノフタリル化合物

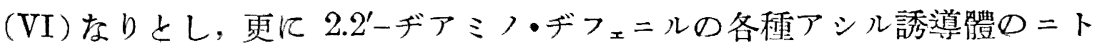
口置換を行ひ類似”獻に準據してニト口基の位置を決定したりく九工紀 6, 327-351)。而して此場合ア七チル及オキザリル誘導體に於ては專ら 5.5'-

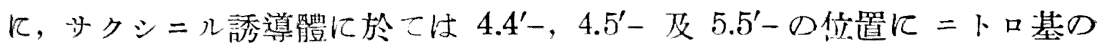
置換せらるってと老認めたり。

有機セレン化合物 鹿松勝左衞門氏はヂフェニル・セレニドのモノオキシ 誘導謴, オキシ・カルボン酸, ヂフェニル・ヂセレニドのヂアミノ・オキシ誘

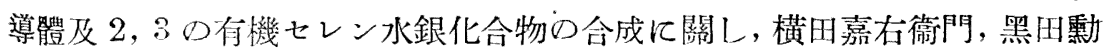
兩氏との共同研究（轫學 52，531-542）並飞横田嘉右衞門，鈴木新太郎网 氏との共同研究（嬊學 52,961-977）走報告せり。 


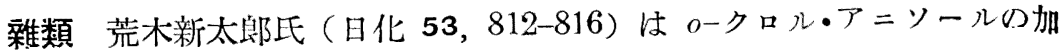
里熔融によるレゾルシンの生成は $p$-クロル・アニソールの場合の約牛量に 過ざざるととを認放，角谷清明，山田昌，田島義正氏等(大工試 12，(18) 1-40) はアセトアルデヒドより醋酸ェチルを製造する際の觸媒アルミニウ ム・エチラートの製法に就て賽驗を重ね, 此場合從來思惟せられし如く必 ホしも絕體無水のアルコールを必要とせホして少量の水を含付するも差支 なをてと, 又觸媒として沃素, 昇承及監化第二鐵を併朋しアルミニウムの 殆ど全量をアルコールと反應せしめ得ることを見出したり。松本常太郎氏 (東商 21，82-87）は 6 種のクレソチン酸並に其カルシウム及ナトリウム 鹽の製造に就て報告し, 高柳義一氏（日化 53，427-432）はア はリン及其

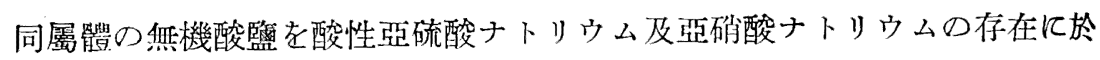
て電解しヒドラジン類を生成せしむる方法に關して研笲せり。

\section{6. 電 氮 化 學}

無聲放電 宮本進氏は姩聲放電に依る多相系化學反應の研究を行ひその 第一段として氣體と固體との反應を驗したり。無聲放電管は硝子製のもの を使用し, 乙の外管は內徑 $4.02 \mathrm{~cm}$, 外徑 $4.48 \mathrm{~cm}$, 內管は內徑 $1.58 \mathrm{~cm}$, 外 徑 $1.82 \mathrm{~cm}$ 者のにして一極は外管の外側に張れる錫箔, 他極は內管に少量 の電解質老含む水を滿たせるるのなり。試料は粉末として反應管に入れ， 始めは感應コイルを用ひ後には代りに變壓器を用ひて反應管て約 $15,000 \mathrm{~V}$ 亚與へたり。而して其第 1 報（日化 53,724）としては 20 種の無機物質 の固體と水素との反應を行忙め, 固體生成物並に氣體生成物の分析を篇 し，第 2 報(同上 788)にては同じ裝置なれど感應コイルを使用せ斗變壓器 により 21 種の無機物質に就て前回と同樣の測定を行ひ，第 3 報（同上914） にては同㥞 19 稞に就を, 第 4 報（同上 933 )にては 20 種に就き測定を 
行ひたり。

光電池 息水永头坁等 (電化 52 號, 49) は濕式光電池が溶液の濃度測 定に應用され得る雪老述べ,又(電化 55 號，126)亞酸化銅を用ふる乾式光 電池の一繁造法を示し, 小川若三郎, 根本忠次郎, 金子清次氏等(本誌 35, $71 \mathrm{C})$ 女亞酸化銅光電池の䌘法に就て述べたり。其他光電池に關しては第 2 回工學會大會電氣部會（同會講演豫稿 204）に於て「光電效果と其の應用」 なる題演のるとに多數の人々に依りて論ぜられたり。

エレクトレトカカルナウバ蠟と樹脂との混合物を融かし, 之を强を電場 飞置きしま〉凝固些しむる時は電場の盐く李りし後まで凝固混合物には正 負の電荷が分極保有せらるつに到り，此帶電狀態は容易に消滅せ亦，斯か

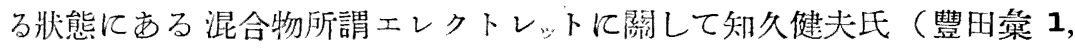

1)は詳細なる研究を行ひたり。

電氣洗透, 電氣泳動及電解透析 駒形作次氏（電會 52, 816）は電氣泳 動度の测定法に就て研究し, 先に發表せる濃厚奬濁液に於ける電氣泳動度 の新测定法として電極への集積現象を利用せる重量法に對して其後に改良 せる装犆の自動化に就て說明し，又（同上 882）代表的電氣泳動測定法な るU 字管法に於ける境界面の状態を驗してその测定法に就ての呤味を行 ひたり。不同氏（同上 977 ；日化 53，342，386，969）は同じく代表的電 氣泳動测定法なる顯微鏡法に就て厗告し, 容器中に生名る電载洷透による 流動狀態に就て諭じたり。

野口孝重, 深井謹次郎兩氏（電會 52, 155）は電氣湥透による連續流水 式浮水槽に就て研究し, 浮水装置に於て水が電槽內を短絡せざるやうに改 良し, 之に依つて水道水及井戶水に就ての試驗安行し且滲透に依る純度高

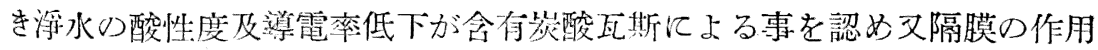

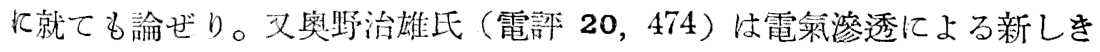


電氣淨水裝置を考察し, 小規模の装幒にて淨水の流水量多く, 且消費電力 も經濟的なる利點圭述べたり。

松浦新之助氏 (日化 53，119）は電解質の膜を透過する速度に關する研 究を引續いて行ひ, 第 6 報として共通イオンを有する强電解質と弱電解質 との透過並に共通イオンを付する 2 種の弱電解質の透過に就て測定し, 共 存せる場合の透過恒數は單獨透過の時の值と異れども何れる各電解質が單 獨に透過せし場合の賽驗式を適用し得る事を磼め，第 7 郝（同上 382 ) に 於ては前報に續いて各種の弱酸の透過速度に就て 测定を行ひ, 又第 8 報 （同上 718）に於ては電解質が單獨に膜を透過する速度に及ぼす溫度の影 響を驗し，透過速度は溫度の上昇に從ひ直線的に增加する事を認めたり。 次で第 9 報（同上 971 ) に於ては第 6 報に於ける實驗の結果を圖示する方 法に就て論じ, 又共通イオンを有する電的哲質が膜の兩側に存在し互に膜を 透過する場合に於ける賽驗絬果を報告せり。加藤二郎氏（化工資 5，(1) 48) は電解透析用隔膜に就て記載し, 岡俊平氏 (本誌 $75,59 \mathrm{C}$ ) b同隔膜 の作用に就て述べたり。又比留間光一比（第2 包工學會大會電氣部會講演 豫稿 199）は電解透析に依万電解質の除去に就て論じたり。

電導度測定 野时稻吉, 三好昆兩氏（本誌 35, 799 ) は濃度の異る數種 の水酸化カルシウムの溶液に就て比電導度を $20 \sim 50 \mathrm{C}$ に於て測定し, 此 値より濃度と比電導度, 溫度と比電導度及濃度, 濃度と比電導度の關係を 表す實驗式を求め，直列圖表を作製叫り。宮本進氏（閻理紀 2，139; Bull。 $C . S . J .7,56)$ は第一錫監の酸素による酸化速度及硫酸と硫酸第一錫混 合溶液の電導度に就て測定を行ひたり。

電壓滴定 西川悅氏（造幣 4, 93，116）以電埾滴定法に關しヶレ一氏 (Kelley) の電厴滴定裝置に就てその使用上に改良を加一，滴定操作として 電壓曲線法, 偏針曲線法, 終點電壓法の 3 種を研究し, 又電厭滴定終點の 
求めオに關し作圖法, 計算法 3 種を舉げ實例によりて說明せり。又箱守新 一郎, 岡好良兩氏 (日化 53,604) 以電壓滴定江關し，2 球式眞空管滴定 装置を考案し, 乙に對する適當をる條件の下に教種の試料就て滴定を行 へり。而して又光電管及真空管を併用せし自動ビュレットを設計し，之を用 ひて沃素の定量をせるに好結果を得をり。

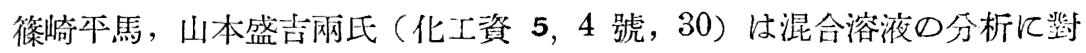
して電㕍滴定法を應用し，多數の實驗を行して息好なる結果を得たるを以 て混合物の定量に該方法を用ひんととを推獎せり。斎藤正一郎氏（理研報 11，593，600）は電厒测定による化學變化の研究を引續いて行ひ，其第1

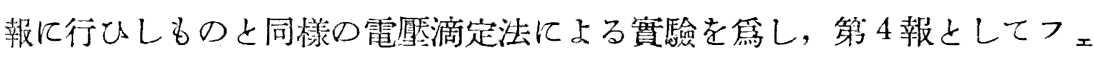
ロシアン化リチウムと亞鉛との反應に就て, 第 5 報として亞鉛とフェロシ アン化アルカリの反應飞對するルビデウム及セシウムの影響て就て驗し たり。又富井公造, 若山一彥兩氏 (本誌 $35,82 \mathrm{C}$ ) はアルミニウムの電塺 電導度滴定法に就て述べたり。

單極電位 一瀨雷信氏 (日化 53，17) は電婳に於ける膠質の狀態を研究 し，金屬析出電位儿對するゼラチンの影響をポーラログラフを用ひて測定 し, 村田寬治氏（本誌 35，589）は鐵極電位差の研究を爰し從來鐵極電位 差の測定值不定なる原因は主として酸素の作用几在るものならんとの推定 几基き, 水素氯中に於ける極電位差の測定を行ひたり。而してその第 2 報 （同上 755）には鐵極電整に對する吸藏水素並に其他諸因子の影響に就て研 究世り。文石原富松，三原金吾，梅津捷夫等 (金屬 9，244）は硫酸亞鉿 の水溶液より亞鉛を電着吃しむる場合の電位差几就て亞鉛量 $0.5 〜 3 N$ なる 硫酸亞鉛の純水溶液を規準液とし之に硫酸を0.5〜3Nの割合に混ゼをる数 十種の液に就て測定在行ひ電假の進行上共に液の組成變化する分極電位 差の變化著しからざるものとして $N . \mathrm{H}_{2} \mathrm{SO}_{4}, 3 N . \mathrm{ZnSO}_{4}$ の如きを適當と 
せり。

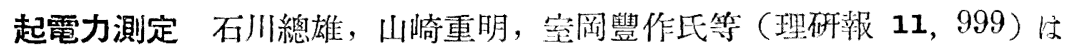
奧貢氏の測定せる銅と其アマルガム間の電位差 $\mathrm{E}_{25^{\circ}}=0.00512 \mathrm{~V}$ の值を確 證せんが䴇に沃化銅及臭化銅電池の起電力を種くなる溫度にて測定し，以 て奧氏の結果を證せり。

正木康作氏 (Bull. C.S. J. 7, 35) \& $\mathrm{Hg}_{\mathrm{F}} \mathrm{Hg}_{2} \mathrm{Cl}_{2}, \mathrm{MeCl}_{2}\left(c_{1}\right) \mid \mathrm{MeCl}_{2}\left(c_{2}\right)$, $\mathrm{Hg}_{2} \mathrm{Cl}_{2}|\mathrm{Hg} ; \mathrm{Ag}| \mathrm{AgCl}, \mathrm{MeCl}_{2}\left(c_{1}\right)\left|\mathrm{MeCl}_{2}\left(c_{2}\right), \mathrm{AgCl}\right| \mathrm{Ag} ; \mathrm{Me}-ア マ ル カ ゙ ム \mid$ $\mathrm{MeCl}_{2}\left(c_{1}\right)\left|\mathrm{MeCl}_{2}\left(c_{2}\right)\right| \mathrm{Me}-$ ア $ル$ ガム（但し $\mathrm{Me}=\mathrm{Mg}, \mathrm{Ca}, \mathrm{Sr}, \mathrm{Ba}$ 及 $\mathrm{Zn}$ )な る三元電解質を有する 3 種の濃淡電池に就き電解液の甚だ稀薄なる 0.001 〜0.01 モル) 種くの濃度に於て起電力を测定し 理論的に算出せる值とよく

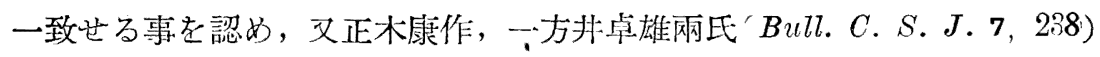
は $\mathrm{Zn}-\mathrm{Hg}$ (飽和アマルガム) $\mathrm{ZnSO}_{4}(m), \mathrm{Hg}_{2} \mathrm{SO}_{4}(s) \mid \mathrm{Hg}$ の電池につき $\mathrm{ZnSO}_{4}$ の濃度 0.00043 3molal $\left(25^{\circ} \mathrm{C}\right.$ ) の起電力を測是し之よ门 0.06 ～3 molal に於ける硫酸亞鉛溶液の活度係数を算出せり。

石川總雄，立术健吉爾氏（日化 53，551）は臭化ナトリウム及臭化カリ ウムに關する熱力學的研究を爲しその熱力學的數值を決定する目的に對し

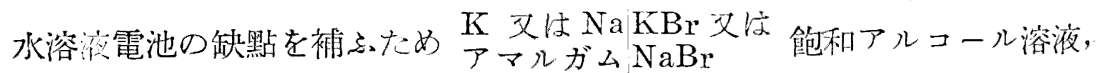
$\mathrm{AgBr} \mid \mathrm{Ag}$ の如きアルコール電池在用ひ其の起電力在测定する事により目 的を達する事を得をり。又柴田善一，佐ぶ木萬夫兩氏 日化 53，593)は金 屬電極のその金屬イオンを含まざる電解質溶液に對する起電力を 金屬水 溶液， $\mathrm{NH}_{4} \mathrm{NO}_{3}$ (寒天)， $\mathrm{N}-\mathrm{KCl}, \mathrm{Hg}_{2} \mathrm{Cl}_{2} \mathrm{Hg}$ に於て金屬には $\mathrm{Au}, \mathrm{Ag}$ 及 $\mathrm{Pt}$ を, 水溶液には $\mathrm{KCl}, \mathrm{KBr}$ 其他多くのものに就て湄度 $10^{-2} \sim 10^{-4}$ の溶 液を用して测定を零し, 不可逆電極による電壓滴定の可能條件を諭じ, 述 水永夫氏 (物理化學 5, 113) は $\mathrm{Cu} \mid \mathrm{Cu}_{2} \mathrm{O}, \mathrm{CuO}$ (共飞皮膜) $N / 10 \mathrm{NaOH}$ $3 N \mathrm{NaOH} \| N / 10 \mathrm{KCl}, \mathrm{Hg}_{2} \mathrm{Cl}_{2} \mid \mathrm{Hg}_{3}$ 及 $\mathrm{Cu}_{\mid} \mathrm{Cu}_{2} \mathrm{O}$ (皮膜) $N / 10 \mathrm{NaOH} \| 3 \mathrm{~N}$ 
$\mathrm{NaOH}|| N / 10 \mathrm{KCl}, \mathrm{Hg}_{2} \mathrm{Cl}_{2} \mid \mathrm{Hg}$ の 2 種の電池を作り。之に光源として太 陽，水銀燈及白熱燈を做ひて電池を照射せし場合及適當なる滤光器を用ひ 單色光線として照射せし場合の電池の電厴の變化を测定したる結果, 酸化 銅極が光の波長に對し選擇的效果をなすてとを認め, 之を利用して水素イ オン濃度测定に應用し得べき事を述べたり。

乾電池 鼠山直人氏（豊田彙 1，87）は乾電池陽極物質の性質及調製法 几關する䂰究を篇し，先づ市販の代表乾電池に用ひらるょ陽極活物質を新 分離法にて二酸化マンガンと黑鉛とに分離し, 二酸化マンガンの化學分析 及スペクトル分析をなし，その中に特殊の有效夾雜物の有無を驗し，“次 天然又は人造の二酸化マンガンと共にその起電力を檢し, 更に交流に依る

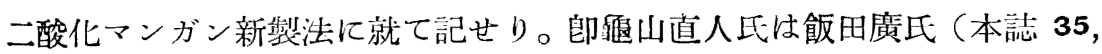
907 ) と共に二酸化マンガン製造に就て 研究しマンガン監の 水溶液を適當 なる條件の下に於て交流にて電解すれば二酸化マンガンの沈搌を生ずるこ とを發見し，乙の製法の要點度其生成機構に就て述べたり。而して同氏等 （同上 913）は上記の方法にて製造せる二酸化マンガンは乾電池用として 優良なることを認め, 適當なる電解條件と沈澱の加熱法とにより密度大に して强力なる乾電池用材料となし得ることを認めたり。又牧野三郎氏（同 上174）名乾電池用二酸化マンガンの研究をなし產地を異にする6 種の二 酸化マンガンに就て加熱減量と電池減極劑としての容量との關係を試驗 し, 比较的州熱減量多き物程, 容量大なる事を認めたり。

蓄電池 檟尾榮氏 (本誌 35, 461; 電評 29, 294，409）はペーステッド 型の鉛蓄電池を高厴の下に放電する時その放電容量が常壓下に於けるより 甚だ增加する事を認めをるを以て此現象が極板つ何れによつて影響される

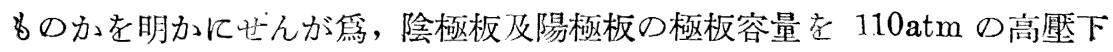
にて各種放電率に就き測定し, 又（電會 52, 345）低壓下に於ける場合の 
特性を驗せんとし同樣の方法にて水銀柱 $13 \mathrm{~mm}$ の壓下に於ける各㮔の放 電卒に就て测定せり。又木下恭二氏（豊田彙 1，43）㹥鉛蓄電池極板の放 電に件ふ重量變化に就て研究し, 重量變化は兩極硫酸鉛說とフェリ一氏說 とあれよ゙放電實驗つ結果岷陽極板の重量の增加を見，フェリ一說は不適當 なれど网極硫酸鉛說には筫测值にある補正を加ふればよく滴合し得ること を認めたり。而して鮫島實三郎, 作绿惈兩比(同上100, は放電狀態に於 ける鉛蓄䉓池極板活物質の本性を確めんため放電せる㓌極板活物筫の分析 を行ひ，含何せる金屬硫酸鉛の量を测定し，次に此割合にて兩者を混合せ る極板を作り充放電を行ひたる結果，陰極板に於ては网極硫酸鉛說をば支 持するに到れり。

北村寒吉氏 (同上 63 ) は蓄電池の陰陽洞極在隔離する木製セパレーター に就て在來の製材法によら尔樹心に直角又は適度つ角度在持つ所酒木口切 斷した薄板を用ひ，その浸透度を試驗し在來品の17 倍乃至 1079 倍の結 果を得たる事を報ぜり。加藤與五郎, 中西岩次郎, 高湖理三郎氏等（同上 $72,78$; 電化 55 號, 120,161$)$ は鉛蓄電池心極板製造上必要㐋方鉛とア ンチモンとの合金に就てその水素過電壓を测定し，その值は電流通過の始 めより次第に變化すること, 電鍍アンチモンの過電壓は低いこと,リーダ 一跑 (Reader)の示す如き鉛アンチモン合金の高過電㰮のものは認められ ぬ事等の事實を確めたり。

北村寒吉, 知久健夫两氏（同上１17）㹥嘗て豊田佐吉氏蓄電池奬賞基 金に依り行はれたる第 1 回移動用蓄電池の發明懸賞募集に於ける多數の應 募の5 5合格せるるの師硫酸系蓄電池 $\mathrm{Y}$ 號, $\mathrm{N}$ 號及アルカリ系蓄電池 0 號の見本について多くつ實地試驗を行ひたる絬柴を發表せり。その他蓄電 池に關する研究としては中村静雄, 鄉功兩比(鐵業資 20,7 號)が國產工 ボナイトクラッド蓄電池 2 種について長期に亘り蓄電池機關輋に積載して 
容量變化の實地試驗を行ひ，その結果陽極は壽命大なれぞ陰極は劣れるこ とを認めをるもの, 又中村䧧雄, 花村誐介兩氏（同上 20,12 號）が列車 電燈用新 I 型堛電池の容量に就て檢したるもり等あり。

電解酸化還元 河田五郎市氏(城生試報 40 號, 279) は嘗てトルオール の電解酸化によるベンズアルデヒードの製法に關する研究を發表せしが， 一般に電解法において電極並儿電解液を反亚作用し得ることの成否は工業 化に重妿なる關係を有するため之に開して種ふ實驗を行ひ, その結果トル オールけ循環法汇传り簡單に且連續的にベンズアルデヒド及安息香酸の純 品を得なるを以て, 該法は立分經濟的儿工業化し得べきものならんと報ぜ り。瀨藤象二, 宮団聰兩氏 (理研報 11, 317) はアルミ二ウム酸化皮膜生 成に關し蓚酸の水溶液を電解液とする場合において主として電解液の濃度 が酸化皮膜の生成に如何なる點において影響を及结すかを詳細に研究し， 而してアルミニウム陽極皮膜生成の機構について考察せり。高山義太郎氏 （日化 53，1197）はアミ)酸及その閣聯化合物の電解反應虑研究し，其第4 報としてチロシン及フィノールアラニンの電拜酸化，第 5 報（同上 1205） として $\beta$ イミダジリルプロピオン酸の電解酸化汇就ての研究結果を發表 せり。正不康作, 一方井卓雄兩氏 (Bull. C. S. J. 7, 233) 妒 $\mathrm{K}_{4} \mathrm{Fe}(\mathrm{CN})_{6}$, $\mathrm{K}_{3} \mathrm{Fe}(\mathrm{CN})_{6}$ の酸化還元電壓に對する $\mathrm{KCN}$ の影響老可逆電池 $\left.\mathrm{Pt} \mid 0.\right) 1 \mathrm{~m}$ $\left.\mathrm{K}_{4} \mathrm{Fe}, \mathrm{CN}\right)_{6}, 0.01 \mathrm{mK}_{3} \mathrm{Fe}, \mathrm{CN}_{6}, \mathrm{KCN}\left(0.03 \sim 1.1\right.$ fimolal $\left.^{2}\right) 0.1 \mathrm{mKCl}, \mathrm{Hg}_{2} \mathrm{Cl}_{2} \mid$ $\mathrm{Hg}\left(30^{\circ} \mathrm{C}\right)$ 飞依りて測定し $\mathrm{E}_{\mathrm{h}}=0.4660+0.0601 \log \mathrm{K}^{0.59}(\mathrm{~K}: \mathrm{KCN} の \mathrm{~m}$ 濃 度）を得をり。又藤岡忠仁，長尾清兩氏（衙生試報 40，9）㹥葆酸上り電 解還元法によりてグリオキシル酸を經て酒石酸（或は蒱蕧酸）の製造を試 み, 又其電解液組成の變移に就て攻究し, 而し二酒石酸（或结葡薇酸）曰 グリオキシル酸に對する良好なる收得率は $65 \%$ なる絬果を得たり。

志方益三, 館勇兩氏(日化 53,834) 屿再び有機化合物の電解還元壓と 
極性との關係に就て述べ，電解還元壓は被還元基に結合する原子團の電氣 的性質に依て影響されんと述へたり。而して同氏等(農化 8, 954)は叉 從來より引續さ行へる有機化合物電解還元壓研究の第 13 報としてアジべ ンゼンの還元壓に就て研究し，その第 14 報として志方益三，保崎信成兩 氏(同上 1121) はヂニトロフェノールの還元壓に就て研究し, その第15報 として志方益三，田口榮一兩氏（同上 1225）はニトロアニリンの還元壓を 測定せり。高柳義一氏 (日化 53，427）はアニリン，トルイヂンの如き芳 香族アミンの監溶液を酸性亞硫酸ソーダの存在の下に亞硝酸ソーダを加へ て電解液となし, 電解によつてヒドラジン類を生成せしめんとする研究を 行ひ, その第 1 報としてフェニルヒドラジンの電解生成に就て研究し, 第

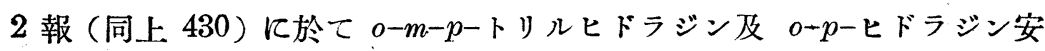
息香酸等の電解生成に就て研究し, 叉 $p$-ヒドラジン安息香酸の定量を当 行ひたり。

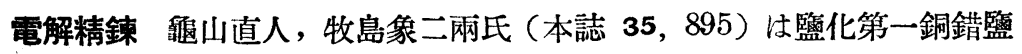
を用ふる電氣分銅法の第 10 報に於て前包第 7 報に報告せる電解液中のア ンチモニーの行雹に引續き陽極夾雜物としてのアンチモニーの行爲に關す る研究を行ひ, 電解液にのみ $\mathrm{Sb}$ を含む場合, 陽極にのみ $\mathrm{Sb}$ を含む場合 及兩者に Sb を含揚合について多數の電解實驗を行ひ Sbの分布移動を 研究し陰極に $\mathrm{Sb}$ は $0.000 x \%$ 以上は來らす，而して酒石酸籃の添加は一 層有效なることを認めたり。又木村善七氏（日鑛 48，541）は前報に引續 き2-クレゾールスルフォン酸と硫酸との混合電解液の粗錫電解精鍊て對す る適當條件を求むる爲數櫄の電解液に就て電解を行ひたる結果を珪弗化水 素酸と硫酸との混合電解液を標準として比較研究し，又平滑なる析離を得 る霞の種くなる條件に就て觀察ぜり。

一小松原久治氏 (造幣 4, 3，62) は金銀の電氣分解に就で詳細なる研究を 
なし，小川芳樹氏（日鑛 48，1289）は亞鉛電解の研究をなしその第 1 報 として電流能率に及敒す諸條件の影響に關し, 硫酸亞鉛の原濃度, 攪拌電 流密度, 遊離硫酸濃度, 溫度等の影響を驗し後之等に就ての理論的考察を 雹せり。

電鍍及電鑄 正木康作氏 (Bull. C.S.J. 7, 158) はシアン化物水溶液 中のシアン化金屬より合金の電解析出に關する研究をなし可逆電池 $\mathrm{Me}$ $\mathrm{MeCN} . x N \mathrm{NaCN}, \mathrm{KCl}|N \mathrm{KCl}, \mathrm{HgCl}| \mathrm{Hg}$ ，その他 2 種に就て起電力を測定 し，その結果より合金の電解析出に對する條件を推定し，之より多くの實 驗を行ひ滿足なる結果を得をる事を報ぜり。又金子清次氏(本誌 35，406) は電鍍液の均一電着性飞就て論じ, ハーリング, ブラム网氏及著者の舊論 を批判し均一性を表す新しき式を提出せり。村上透氏(日化工 16，44)は 鍍金の物理性質に就き，石田武勇氏（科工 7，28）はク口ム鍍金に於ける 陽極に就て述べたり。而して持田德彥氏（電化 56, 10) は防蝕の目的によ りアルミニウム及その合金上へのニッケル電鍍を研究し，ジュラルミン上に はよく電鍍され防蝕の目的を達し得られる事を認めたり。又弱山直人，飯 田廣兩民（本誌 35，59C) は低溫熔融電解に依るアルミニウムの電鍍に就 て述へ，藤井毅太郎，小西義雄兩氏 (本誌 35，59C) は高溫電解による金 屬鍍金法に關しアルミニウム上へ他金屬を强く鍍金する方法に就て述べた i)。

電鑄に關しては䦠山直人，岡宗次郎兩氏（電化 56, 157 ; が電解に依る 有底肉厚ニッケル管の製作に就ての必要なる條件及注意すべき點を舉げ， 又前述せる小松原久治氏（造幣 4, 62）は金銀の電解研究に附帶して銀の 電鑄に關する研究を行ひたり。

電氣爐 向山幹夫氏 (電化 53，66) は抵抗線電氣爐設計に關する基礎的 研究として電氣爐の電氣大力ー爐內容積一溫度の關係を求めんため實驗を行 
ひ，ての 3 者の關係を表し得る二つの䁈驗式を誘導せり。又井上克己氏 （日鑛 48，259）は電熱線の材質に就て論じ,杉野喜一郎氏（電化 54, 108;

55，136）は電氣爐工蒋製品より有機化合物の製造に就て述べたり。

綜說 日本鑛業會誌 10 月號 (48,570號) は輕金屬號とし.てアルミニ ウム及マグネシウムに關する論說講義が多數記載され，血山直人氏（本誌 35，1337）为輕金犀に於ける電解精製の問題に就て論じたり。又水電解槽 版關し橫山武一氏（日立評論 15，599）は一般電解槽及日立製作所の電解 槽に就て概要を述べたり。

\section{7. 酸, アルカリ及肥料}

本部門全般に涉る記事 石川一郎氏（本誌 35，1068-1076) は化學工紧 の統制に關する所見中, 過燐酸, 硫安, 硫酸及曹達工業等につき述べ,1933 年本邦酸，アルカリ及肥料工業の近狀につき統計的記事は化學工業年鑑に 示さる (同書 92-98), 庄司務氏(本誌 35，483-490) は人造肥料工業に於 ける最近の進步に就て, 又橫山武一氏（本誌 35，842-848）は昭和肥料株 式會社川崎工場几就き述へ，同工場が本邦人により設計せられ，使用諸機 械の國斊品たる事を力說せらる。

本會關西支部常會中北陸道に開汃しものは昭和 7 年 5 月 15 日大日 本人造肥料株式會社七尾工場の見學老なし，同工場長山賀源三氏の案內に て同所の硫酸並に過燐酸工場を一巡せり(本誌 $35,107 \mathrm{C}$ )。

硫酸工業 松原厚, 澤村武雄兩氏（地質 39，343-344）はスミッツ氏石 英㗂子測壓裝置を用ひ，硫化鐵鑛の所罗離壓を测定し，次の實驗式を示せり。

黃鐵鑛 $\quad \log p=54972 T^{-1}+1.791 \log T+587.997$

磁硫鐵鑛 $\quad \log p=1093.3 T^{-1}+8.355 \log T-22.9057$

黄鐵鑛の場合分解厴の $1 \mathrm{~atm}$ を呈する溫度は $674^{\circ} \mathrm{C}$ にて, 實驗結果 
より解離熱を算出すれば黄鐵鑛は $72000 \mathrm{cal}$, 磁硫鐵鑛は $25000 \mathrm{cal}$ となる。 松井元太郎氏(學術協報 7，493-500) は硝酸式硫酸製造の硝酸自働供給 法につき再度綜合し示せり。松井元太郎, 加藤弘人兩氏 (鉛室式硫酸製浩 法の研究, 第 23-24 報, 本誌 35, 780-784, 784-788) は鉛板の物理的並. に㙨械的試驗索行ひ, 比重, 硬度, 融點, 抗張力, 延伸率並に燒杘が抗張 力, 延伸率及硬度に及卧す影響につき測定し, 自製の硬度試驗器を紹介せ り。次に鉛板の硫酸及含硝硫酸並に鉛室內瓦斯中の腐蝕試驗，别にフラッ シュ試驗の結果につき報ぜり。三浦彥次郎氏 (北光 31，22-27). 恃鑛烟除害 と硫酸工業につき述へ，四坂島製鍊所の絬果を例示せり。山村義次氏（化 工資 5, (2) 46-55,（3）41-49）は耐酸セメントに關する陚驗結果を述べた り。今井武光氏（化工時報 5, (29) 17-19) はキュールマンインダシュミー 式バナディウム接觸法に依る硫酸製造法につき述べたり。

柴田榮一，織田三郎兩氏 (日化 52，590-600) は化學熱力學研究第 16 報 として,メチルアルコールと水の混合液中に於ける硫酸の活度係数を測定 せり。

其他の酸類 佐藤健三氏 (石油 635, 918-919) は天然瓦斯, 燃燒廢瓦斯 より固形及液體酸化炭素の製造につき述べたり。

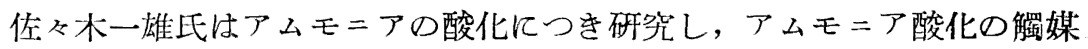
(東工試 26, (11) 1-49); 加壓下に於けるアムモ=アの接觸的酸化 (東工試 27，(3）1-24)；アムモ=アの自己燃燒性に關する研究（東工試 27，(3) 25-41)；更に高濃度のアムモ=アの接觸的酸化 (東工試 27，(3) 43-48) に ては 98\%の酸素に 30\% 位のアムモニアを加へたる混合瓦斯を用ひ，觸 媒前の冷却裝犆につき攻笑せり。

製鹽工業 專賣局研究所に於て, 鈴木寬, 坂場寬网氏（尌㸴報 35, 120) は 15〜80 $\mathrm{C}$ に於ける海水並に瑊水の比重を測定し, 夫等の關係式を 
求め, 藤貫淸, 浦山貞雄网氏 (專研報 36, 1-23) は喊水の物理的性質, 郎 普通威戍より飽和液に至る迄各種濃度の8の及苦汒の比重, 表面張力, 粘

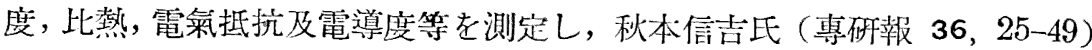
は虚水の理化學的性筫を攻究し, 10 ～ $20^{\circ}$ Bé のもの 11 種につき $\mathrm{pH}$ 值

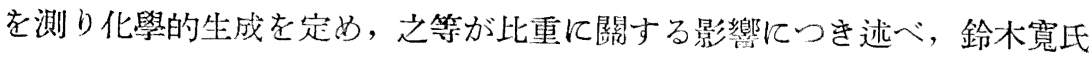
（專研報 37，1-29）は雗石の組成, 雗石生成の機棈及之が豫防法につき,

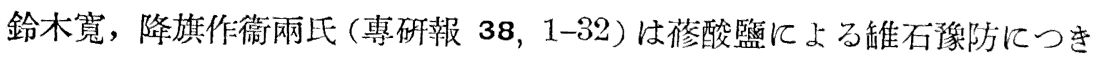
報ぜり。

岡宗次郎氏（本誌 35，524-531）は食監結晶の不透明性なる理的走極む る爲に食鹽水溶液より諸種の物理的及化學的影響の下に食監の結晶を生ぜ しめ之を檢查し, 透明體は結晶集團中に母液を含有せざる結果にして丸澤 常哉, 山本健鹰兩氏等の Mn イオン添加の影響につき言及せり。加藤虎郎 氏(苦汁の利用法第 5-6 報, 南滿試 16, 99-106，107-114) は苦汒の利用 法中，鹽基性炭酸苦土及臭素の包收につき述べたり。

本會滿洲支部發會式に際し, 昭和 7 年 7 月 24 日に大日本監嶪株式會社 双島灣監田並に再生鹽工場, 及旅順の關東廳試驗覧田特に特殊監の試驗に つき見學せり(本誌 $35,158 \mathrm{C}$ )。

曹達工業 柴田榮一, 村田房一及豐田豊氏等は水酸化ナトリウム水溶夜 中への水酸化ナトリウムの微分溶解熱 (日化 52，627-634); 水酸化カリゥ 么水溶液中への水酸化カリウムの微分溶解熱 (日化 52, 635-638); 硫酸ナ トリウム氷溶液中への硫酸ナトリウムの微分溶解熱（日化 52，639-644); 又柴田策一, 村田房一兩氏は濃厚溶液に於ける水酸化カリウム, 水酸化ナ トリウム文硫酸ナトリウムの活度係数 (日化 52，645-650); 村田房一氏は 硫酸カリウム水溶液中一硫酸カリウムの微分溶解熱及濃厚水溶液に於ける 硫酸カリウムの活度係數(日化 53, 574-579) 测定報告せり。植田勇二氏 
は水酸化リシウム及監化リシウムの熱力學的磻究 (日化 52，740-755) を, 又同氏は硫酸りシウムの熱力學的研究（日化 53，559-565）を發表せり。 松非元太郎，神原周及宮村勝治氏等（本誌 35，657-662） は對照熱量計 (Double or Twin Calorimeter) 在用し $\mathrm{Na}_{2} \mathrm{CO}_{3}$ の $1000 \mathrm{~mol} \mathrm{H}_{2} \mathrm{O}$ 一の水 溶解熱を测定し, $25^{\circ} \mathrm{C}$ にて $5670.8 \pm 8.1 \mathrm{cal}$ と決定せり。因に同器は直接 溫度の測定京なさが, 電流の積算值よりエネルギーを計算するものとす。

岡田家武氏（上海科研 1，(4) 3-148）は天然ナトリウム化合物研究の 第 1 報として東部內蒙古 (Dtabusu-nôr) 產 Gay-Lussite につを述べ, 奥野俊郎, 宮崎兄一及別府次郎氏等 (本誌 35，328-332; 詳細は九工巢 7, 1-13； 45-53；101-109）は硫酸曹達の研労立行ひ， $25^{\circ} \mathrm{C}$ に於て $\mathrm{Na}_{2} \mathrm{SO}_{4}-$ $\mathrm{H}_{2} \mathrm{SO}_{4}-\mathrm{H}_{2} \mathrm{O}$ 系につを测定し, $\mathrm{NaHSO}_{4}, \mathrm{NaH}_{3}\left(\mathrm{SO}_{4}\right)_{2}$ の分解壓を夫を $182 \sim 415^{\circ} \mathrm{C}$ 及 $180 \sim 450^{\circ} \mathrm{C}$ の間に測定し, 其 $760 \mathrm{~mm}$ 呈する溫度は前 者にありては $415^{\circ} \mathrm{C}$, 又後者にありては $465^{\circ} \mathrm{C}$ と定め, 更に複監の結晶構 造老 $X$ 線的に攻究地り。

石川總雄, 室岡豊作及萩澤浩氏等 (理研報 11，284-296) は炭酸ナトリ ウムと鹽素の反應老, 又石川總雄, 萩澤浩兩氏（理研報 11, 297-303）は 炭酸カリウムと監素の反應につを報ぜり。正木清氏（英文 Biochem. 15, 29-32 は水酸化カリウム及水酸化ナトリウム溶液一炭酸瓦斯の吸收速度 を, 宮本進, 賀屋哲夫兩氏(英交 Bull. C. S. J. 6, 264-275) \& $\mathrm{Na}_{2} \mathrm{~S}_{2} \mathrm{O}_{3}$ 溶液へ酸素の吸收速度老測定せり。

松井元太郎, 神原周兩氏 (本誌 35, 788-794) は膨脹計使用含水將類の) 轉移點测定につき賲驗し, 先づ膨脹計の形狀と感度の關係を調查し, 溫度測 定には標淮白金寒暖計にて檢度し, 精密測定の上 $\mathrm{Na}_{2} \mathrm{SO}_{4} \cdot 10 \mathrm{H}_{2} \mathrm{O} \rightarrow \mathrm{Na}_{2} \mathrm{SO}_{4}$ 生 $32.377^{\circ} \mathrm{C}, \mathrm{Na}_{2} \mathrm{CO}_{3} \cdot 10 \mathrm{H}_{20} \rightarrow \mathrm{Na}_{2} \mathrm{CO}_{3} \cdot 7 \mathrm{H}_{2} \mathrm{O}$ は $31.97^{\circ} \mathrm{C}, \mathrm{Na}_{2} \mathrm{CO}_{3} \cdot 7 \mathrm{H}_{2} \mathrm{O}$ $\rightarrow \mathrm{Na}_{2} \mathrm{CO}_{3} \cdot \mathrm{H}_{2} \mathrm{O}$ \& $35.55^{\circ} \mathrm{C}$ と決定せ り。又松井元太郎, 神原周及吉野晴方 
氏等（本誌 35，794-i99） は精密に檢度せるベクマン然暖計使用，前記同 样の實驗を行ひ， $\mathrm{Na}_{2} \mathrm{CO}_{5} \cdot 10 \mathrm{H}_{2} \mathrm{O} \rightarrow \mathrm{Na}_{2} \mathrm{CO}_{3} \cdot 7 \mathrm{H}_{2} \mathrm{O}$ の轉移笘を $31.91^{\circ} \mathrm{C}$ と 決定せり。

入江展雄氏（大工試 12，(12）1-38）はクリオライトの人工的製造の 第 1 報として $\mathrm{Na}_{2} \mathrm{SiF}_{6}$ より $\mathrm{NaF}$ の生成につき報じ, 田中程, 柳喜久雄 兩氏（衞生試報 40,243-258）は $\mathrm{Na}_{2} \mathrm{~S} \cdot 9 \mathrm{H}_{2} \mathrm{O}$ の製造試驗の成績を報じ， 30 35\% $\mathrm{NaOH}$ 溶液中へ $\mathrm{H}_{2} \mathrm{~S}$ を暹る操作につき述べたり。

植村四郎，阿部末吉艾原龍三郎氏等（本誌 35，881-887）は食邷より炭 酸曹達製造の一新法として，食監を液態アムモニアに溶解せしむれば $\mathrm{Ca}$ ， $\mathrm{Mg}$ 監類より精製し得る事，之に壓搾岑酸を迕りカーバメートに變じ，之 を水蒸氣により分解し炭酸曹達を得, 同時にアムモニアを包收することを 實驗せり。䶛山直人，宗像英二兩氏（本誌 35，1298-1304）は高厴に於け るアムモニア曹達法を實驗し，10 及 $20^{\circ} \mathrm{C}$ にて各 20 及 $40 \mathrm{~atm}$ の作業 を示し，結果製造法には大なる影響なけれども，只適及不適飽和點の變化 が低壓の場合と㟥するが如き事を述べたり。

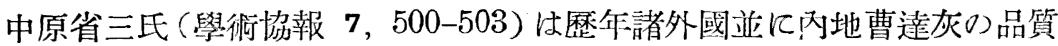
向上の模樣につき示し, 本邦使用不純なる食監原料の精製の困難なる事を 述ぺり。松井元太郎, 野田稻吉, 神原周及小山田茂氏等 (本誌 35, 14271434，1434-1437）汇光電管による奬罚液の濃度分散度の測定法を應用し， アムモニア曹達製造》工程中清澄献水を試驗し，同一の工場操業に於ては 液中の嶈濁質の結晶生成條件の略均一なる座示し, 又各種製品の曹達灰の 水溶液中奬濁液の消隇より夫等の濃度を知り得る事, 但し天然曹達系統の ものにありては溶液着色の爲, 之等の關係より偏倚する事を述べをり。 西川虎吉氏は曹澾工業の現在と將來（本誌 35，515-521）及滿洲の曹達

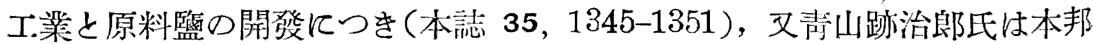


赪性曹達の状況（化工時報 5, (35) 12）につき述べたり。

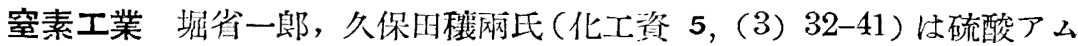
モニウム水溶液り比重と其溶解度につき, 山本健麿氏（理破報 11, 10831092）は篮化アムモニウムの結晶の成長に及注す金屬イオンの影響につき 述べたり。

渡邊定良比（化工资 5，(4) 53-59）は本邦に於ける昭和 6 年硫酸アムモ ニア及石灰䇪素需給の狀況につき報ぜり。

燐酸工業 庄司務, 鈴木策三郎及七井永壽氏等岋引續き過燐酸石灰の眝 藏中に於ける水溶性燐酸分の變化につき研究し, 第 5 報 (本誌 35，46-52) には燐酸一石灰と硫酸カルシウムの反應を, 第 6 報（本誌 35，390-394） は燐酸一石灰と硫酸鐵との反應を, 第 7 報（本誌 35，1023-1029）は燐酸 一石灰と酸化鐵との反應につき述べたり。

アルカリ土鹽類其他 田丸篩郎，監見賢吾及安達正明氏等（日化 53, 329-341)はテルコノワーゲによる岑酸カルシウムの熱解離本衡の测定をな し， 614 $891^{\circ} \mathrm{C}$ の間に汒固溶鳢の生成なく,其間の 7 測定值より次の分解 壓實驗式老呈したり。 $\log p=-39670 \times(575 T)^{-1}+10.385 ; \log p=-9220 T^{-1}$ $+1.70 \log T-0.00149 T+1.443 \times 10^{-7} T^{2}+7.181$ 。田犯部，鹽見賢吾兩氏 （日化 53，647-649）は炭酸ストロンシウムにつき同樣の測定をなし820〜 $1250^{\circ} \mathrm{C}$ の間にて次の賽驗式を呈したり； $\log p=-49090 \times(4.575 T)^{-1}+$ 9.933 。尾藤堅, 靑山幸造及松井元太郎氏等（本誌 35, 553-559) は水洲石 (アイスランドスパー) の炭酸瓦斯氣流中の加熱變化をネルンスト氏微量 天科にて测定し, 新試料は $-928 \sim 929^{\circ} \mathrm{C}$ (第 1 分解點)にて分解起引, 更に 一度分解行程に遭遇せるものは再度及之れ以後の場合は常に $914 \sim 915^{\circ} \mathrm{C}$ (第2 分解點)にて分解の始まる事を認めたり。野田稻吉, 小山田茂及本城 筩氏等（本誌 35，332-340）は本邦に於ける石灰燒成爐の作樂に關し, 諸 
種賽測の結果より操業の改良點を注意せり。野田稻吉, 三好昆网氏（本誌 35，799-804) は水酸化カルシウム水溶液の電導度を測定し, 濃度 0.02 $0.001 \mathrm{~mol} / l$, 溫度 $20 \sim 50^{\circ} \mathrm{C}$ 亿つを實驗式と直列圖表を作製せ门。杉野喜一 郎, 立木健吉及藤野茂氏等(電化 51，9-12) は消石灰の大放る結晶の製法 及其絬晶の光學恒數につき報ぜり。求野武雄氏岋瓦斯-固體間の反應の研 充(英文) 中第 1 報 (Bull. C.S.J. 6, 294-301) は $\mathrm{CaO} に \mathrm{H}_{2} \mathrm{O}$ の吸收速 度, 第 2 報 (Bull. C.S.J. 6, 319-324) は $\mathrm{CaO}$ 及 $\mathrm{Ca}(\mathrm{OH})_{2}$ ○ $\mathrm{CO}_{2}$ 吸收速度, 第 4 報 (Bull. C.S.J. 7, 247-255) は $\mathrm{CaC}_{2}$ の $\mathrm{N}$ 涯加, 及 溫度の影響につき報や゙り。

向斗參之充氏 (九工彙 6，272-282) は硫化バリウムのハロゲン酸化及過 酸化窒素酸化（九工彙 7，30-44）には硫化バリウムの脫硫にて水酸化バ

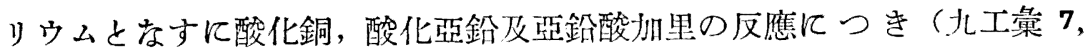
130-136) 第 2 鐵イオンによる硫化バリウムの脫硫につき述べたり。

石川總雄, 佐野幸吉爾氏（日化 53，703-707）は酸化マグネシウムによ る水蒸氣の吸着につき, 鈴木庸生, 今富漼一郎, 尾間一彥及永井亮三氏等 （本誌 35，945-954)はマグネサイトを原料よする金屬マグネシウム製造 する工業的方法につき述べたり。

河田五郎市氏(衞生試報 40，149-159)は過酸化物製造試驗成䋶、第 2 報) として $\mathrm{CaO}_{2}$ 及 $\mathrm{SrO}_{2}$ の製造並に過酸化物の安定度につき述べ，藤岡忠 仁, 大木俊夫兩氏（衞生試報 40,215-236） は濃厚過酸化水素液の製法 （第 1 報）につき報ぜり。

\section{8. 鑛物, 冶金及金工}

本部門の研究範圍忙廣く報文の数多し, 其多くは他の專門諸雜誌に揭載 あるものなり，此處に蒐集分類して示す。 
鑛物及岩石の成分 宮城縣產大谷鑛山崖テルル荅鉛颌 渡邊萬次郎氏 (岩石 6, 201), 本邦油田泥岩の化學成分 高橋純一氏（岩石 6, 8, 101, 162), 天然産ナトリウム化合物研究（其 1) 東部內蒙古産ら゙ーリュサイト 岡田家武氏 (上海科研 1，(4) 3), 長野縣山口村產コルンブ石 木村健二 郎, 衡田榮兩氏 (岩石 6,167 ), 本邦産亞鉛鑛中に含まる」稀有金屬凹研 笢 今泉羓夫氏 (北光 31,7 ), 東京口-

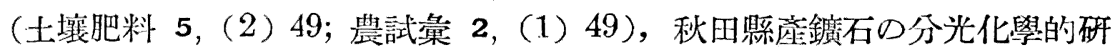

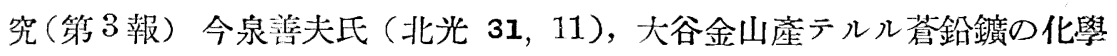
成分 八朴次男氏（岩石 6,224）, 黃海道溫泉分析成績補遺 小島來太郎 氏（朝鮮染學 2，(11）(10), 眉丈山地帶附近の鑛泉及び池沼水並に黑部 川流域に於ける 1，2 溫泉のラドン含有量 飯盛里安, 吉村恂, 畑晋氏等 （理研報 10，1131），東洋產含稀元素鑛石の化學的研究（其 18-19） 木村 “健二郎, 三宅泰雄兩氏 (日化 53,91，93）, 駒万岳噴出岩中几於ける硬石 高(1) 吉水文本氏（岩石 7, 20）, 化學成分上り見をる魚岩と綠色凝灰岩 三原柴氏 (岩石 7,61), 本邦崖亞鉛鑂中に於ける金屬元素の配分狀態 今 泉寚夫氏(日化工 16，9), 天鹽國産エデリン辉石藍閃石英片岩 鈴木醇氏 (岩石 7,11), 駒与岳產浮石の化學岩石學的研究 (2) 神津俶鿆, 瀨戶國 勝兩氏（岩石 7,1), 長手石の結晶化學式と名稱 畑晋氏(科學 2, 100),

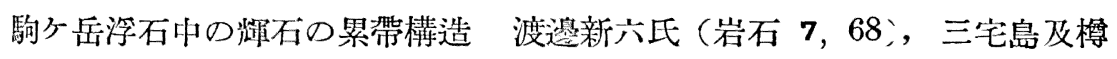
前岳灰死石研究補遗 渡邀新六氏 (岩石 7, 18), 秋田縣產鑛石の分光

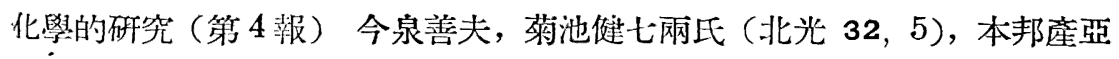
鉛穔中に含まる」稀有金屬の研究（第 2 報）今泉善夫氏（北光 32,8 ), 靜岡縣足柄上郡三保村玄倉尘燐灰石の化學成分 瀨戶國勝氏（岩石 7 , 180)，駒ケ岳新噴出岩中に於ける硬石旁（2）吉木文本氏(岩石 7, 51), 萠紀東车婁那太地重加里アノーソクレース 君塚康治郎氏(地球 17, 171), 
筑豐炭田に於ける含古銅石鄆石安山岩 上治寅次郎氏(地球 17,243)，工 ヂブト產檄欖石の化學成分 鶴見志津夫氏（岩石 7，228），神流川筋柏木

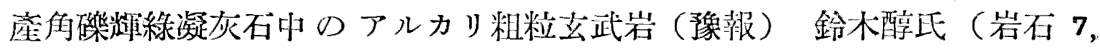
205), 出雲八束郡來待村附近產の㠜灰岩質砂岩及石粉 酒井榮吾氏（地

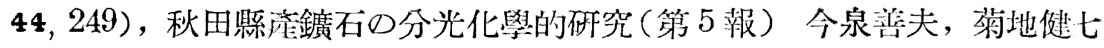

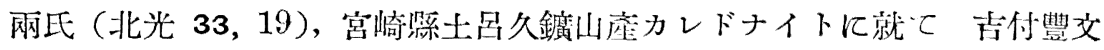

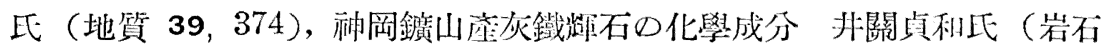
8, (2) 26), 足尾鑛山の硫砣鐵鑛 岡田以知二氏 (地質 39, 361), 信澸仁科 山脈に產する石英閃長岩樣アルカリ岩類 笹倉正夫比(地質 39,279), 北 海道の特殊火山岩 根本忠宽氏 (地質 39, 285), 楢陵島火山の扰出物 春

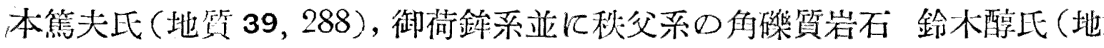
質 29，292), 本邦崖花嶥岩の化學性 鈴木醇, 根本忠寬兩氏(岩石 8, (2) 1; 地質 39，294), 整城國石川地方の含稀土類ペグマタイト 柴田秀賢氏

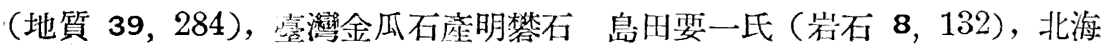
手稻鑛山㡾天然テルル鑛 渡邊萬次郎氏（岩石 8,73），土壤中に於ける監 素の定量 板野新夫，松浦章兩氏(農研 19, 199)。

鑛物及岩石の科學的㸴究 黑曜石の硫酸に對する溶解度 可兒弘一氏 (岩石 6,226), 网質異態の結晶格子間に於ける 幾何學的關係 庄司彥六 氏(理研報 10，909; 日化總 3，339，4，99),一酸化鐵一哭水珪酸 2 元系の研 笑(英支) 山田賀一氏 (京工紀 6, 251; 日化總 5,88)，酸性白土と其應 用 小林久平氏 (本誌 34,1198 ), 鑛石, 岩石, 土壤, 坑內水等の電氣固

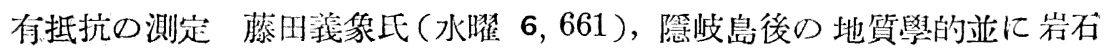
學的硎究（其: 13）富田達氏(地質 38，461), 玄武洞產玄武岩に類似の成 分を有する人造硝子の熱分解及爇膨脹 可兒弘一氏(岩石 5,272 ), 監基 性岩石熔融物の物理化學的性質に對寸る溫度の影響 可兒弘一, 森安靜太， 


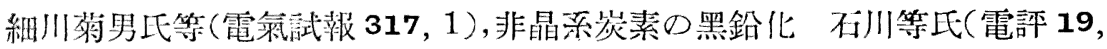
$419,493,613,690,726,824,838)$ ), 粘土の酸度 板野新夫, 荒川左千代, 松浦 淖氏等(豐研 17，118；二酸化チタンの還元 梅津七藏氏(鐵鋼 17，1232)， 酸化チターウムと䇪素とより窒化チタニウムの生成(英文) 梅津七藏氏 (P.I.A.7，353), 物質の變態により生ホる結晶軸の方向變化に關する X線的研究 庄司彥六氏(金屬 9,31), 隱肢島後の地質學的並飞岩石學的研究 (其 14)富田達氏(地質 38，545), 錫石鑛石分析の一新法 田丸節郎,安藤逷 兩氏(日化 53，71), 結晶體の熱的歪によるX-線反射力の變化 向坂義太 師, 數元伊之助网氏(理研報 11，135), 陑極線の反射により結晶の內部ポテ ンシアルの決定(英文) 山口太三郎氏(數物 III, 14，1）, 䖝石の超感光と 發光變移律 飯盛里安, 岩瀨榮一兩氏(日化53，77; 日化總 5, 421), Northupite, Bromide-Northupite 及 Tychite の結晶構造 芝彥一，渡邊得之 助网氏(理研報 10，931), 酸性白土の品位判定法 小林久平氏(石油 636, 43)，曲げたる硫水鉛鑛 $\mathrm{MoS}_{2}$ による陰極線の反射(英文）山口太三郎氏 (數物 III， 14，57)，鿵岐岛後の地質學的並に岩石學的砰究(其15) 富田 涬氏(地翼 38，609), 海綠石岩石の粒度組成 八木次男氏(岩不 7, 107),

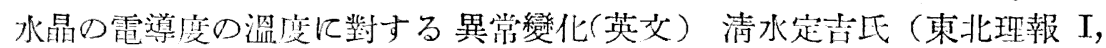
$21,59)$, 永洲不の第 1 及第 2 分解點, 炭酸カルシウムの炭酸瓦斯氣流中 の加熱變化(第 2 報) 尾藤堅, 靑山幸造, 松井元太郎氏等(本誌 35, 553),

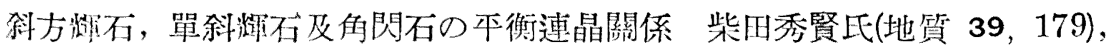
火山灰の利用试驗(第 1 報) 中根俊雄, 山岡三秋网氏(北工試 35,1 ), 酸 性白土類の吸着作用(第 2 報)水溶液中上り色素の吸着並に其機桠理論 田 中芳雄, 桑田勉, 古田処氏等(本誌 35,$649 ;$ 日化總 6, 243), 耐岡鑛山

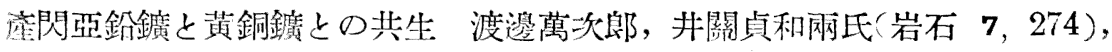
十字石と紅柱石の共存關係 鈴木醇氏(㞸石 7，101，160)，ボーキサイト 
の加熱曲線及脫水曲線より其組成の推定 桶口正吉氏(電化 52, 40), 硝 子質火山岩によるX-線䞨折 平田守三氏(科學 2,227 ), 火成岩に於ける 有色鑛物と無色鑛物と口隨件關係並に其化學成分 豐田英義氏(地質 39，

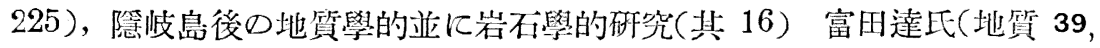

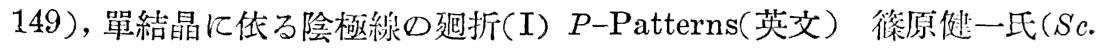
$P .18 ， 223)$, 結晶のラマン效果(續報)附結晶水(英文) 西久光氏 $(J . J$. P. 7, 1), 燐酸監並に珪酸監のラマン效果, 附ジルコンのルミネッセンス （英文）西久光氏(數物 III，14，214), 滿洲朝解產鑄物砂の機械分析結果 より見たる物理的性質 松堟清人氏(旅工彙 20，1)，火山石及火山灰に上 る X線趈折(英文) 平田森三氏 (Sc.P. 18，237)，雄黃及辉安鑛の溶解 並に沈澱に關する賽驗(續報) 渡邊萬次郎E:(岩石 7，251)，單結晶によ

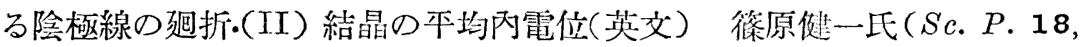
315), 螢石の熱發光と光發光 岩瀨榮一氏(理研報 9,910), 自然水晶の 燐光と着色 伊藤集赎氏 ( マツダ 7,87), 天然瓦斯中に含有せらる১へリ ウムの液化と固態化 長岡牛太郎氏(石油 643, 635), 岑酸石灰の炭酸瓦斯 氣流中の加熱變化, 附固靖の加熱分解と試料量の關係 松井元太郎, 尾藤 堅兩氏(東工學報 1，239; 日化總 5，287),X一線趗折に於ける溫度效果を 用ひて方解石結晶構造の酸素イオン變數の決定(獨文) 福島榮之助氏（廣 理紀 1，195), 斜長石の透電恒數 田久保蒀太郎氏(地筫 39，325!，玄倉 產監素弗,素燐灰石の研究(概報) 神津俶鿆, 上田閵一兩氏(岩石 7, 153), 岩漿より辉石の晶出する徑路 坪井誠太郎氏(地質 39, 298), 古銅泻石の 結晶構造 高根勝利氏(岩石 7，120，169，212; 地質 39，331)，黃鐵鑛の

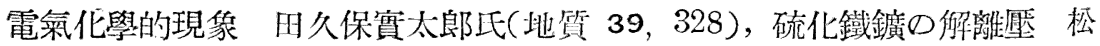

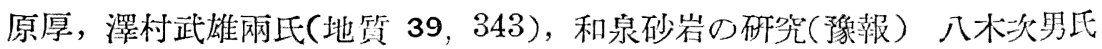
（岩石 7，220，267），七星山及其附近に於ける安山岩の地筫鼠的研究， 
大屯火山彙に關する地質化學的研究（II）國府健次，山下一男网氏(臺督 研工報 69,1$)$, 丹那隧道及花岡鑛山坑道內粘土の吸水膨脹, 粘土の “吸 水膨脹” 四關与る實驗的趼究(第 1 報) 福富忠男氏(岩石 $7,259,8,12$ ), 三保山ベスーブ石 吉木文平，渡邀新六兩氏(岩石 8, 28), 所謂古銅石安 山岩 吉澤甫氏(地質 39, 282), 山形縣新庄町及大石田町附近に於ける火

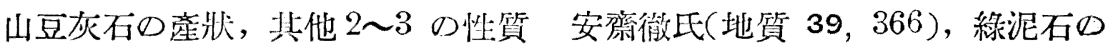
ハルミロリス 高橋純一氏(地質 39，383), 滑石に關する一實驗(其 1 ) 伊藤集悀氏(マツダ 7,81), 京都帝國大學醫學部構內整井地質之地下水の 研笑上治寅次郎, 和田正美兩瓦(水矅 6,845), 日本の基性火山岩の石 基に珪酸鈸物の存在 圤井誠太郎, 久野久网氏(地質 39, 297), 本邦産燐 灰石の特質的構造 原由潐平氏(地質 39，334），旅順市附近の土壤の電氣 抵抗测定 佐藤芳夫, 村越二男兩氏(旅工晕 21，1), 低溫に於ける磁鐵鑛 の變態 (英文) 岡村俊彥氏(東北理報 I, 21, 231), 酸性白土の比重 山本 研一, 石川本七兩上(早應化 17，1), 溫泉の水素イオン濃度 木村正一, 深水要人雨氏 (北游醫 10, 1653), 三酒熔岩型火山岩中に於けるクリスト バール石の發達(1-2) 吉木交平氏(岩石 8，18，61)，トレマドック㡾板チ タン石の光軸危の分散現像 神津俶鿆氏(岩石 7, 127), 低溫飞於ける磁

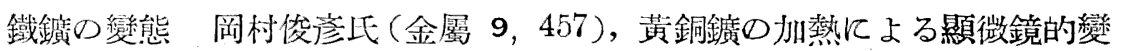
化 中野長俊氏(岩石 8,120), 金屬鑛石の顯微鏡的共生 渡邊萬次郎, 中野会俊兩氏 (岩石 $8,30,79,99,136$ ), 隐岐島後の地質學的並に岩石學 的研究(其 17) 富田達氏(地質 39，197), 滿洲土壤中に存在する鐵結粒 の成因江就て 哭永一枝氏(滿鐵農研 7, 43)。

鑛床 北海道國富黑鑛及休(I-II) 渡邊萬次郎氏(岩石 6，120，151)，

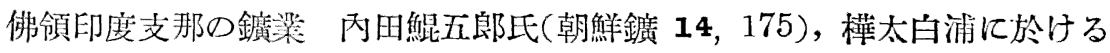
硬質頁岩接能變筫 三原榮氏(岩石 6,215), 本邦の主要なる溫泉の分布 
大井上義近氏(地 43，559), 古代文獻に顯れたる朝鮮の鑛物 川崎繁太郎 氏(朝鮮率學 10，209), 油澲する火山灰の作用, 本邦産石油の起原(英 文) 寺田寅彥, 平田森三, 內5-崎直郎氏等 (Sc. P. 17, 265), 大和水銀 鑛山 村井一郎氏(日鑛 47，1163), 朝鮮產鑛物(2) 木野崎吉郎氏 (朝鮮

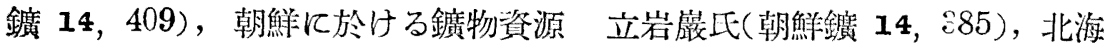
道有用鈸物調查報文（第 2 報）渡島支廳管內松前郡東牛部上磁郡全部垦田 郡西一部 福富忠男氏 (北工試 34，1)，歐洲第一の金山 倉內吟二郎氏 (水曜 6，779), 北海道に於ける藍閃片岩類の原產地 鈴木醇氏(地質 39, 132)，ベリリウム鑛の發見 上治寅次郎，塚本成之兩氏(水曜 6, 755), 神 岡鑛山栃洞鑛床產珪酸亞鉛鑛 渡邊萬次郎, 井關貞和兩氏(岩石 8, 1), 田

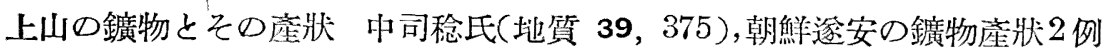
(a)スカポライト (b)䇗洞鑛床銅鑛 渡邊武男氏(地質 39, 370), 千桨縣大 多喜町近在の天然瓦斯及それに件ふ地下水 三川逸郎氏（地質 39，349）, 歪頭山附近の地質鑛床 都留一雄氏（旅工彙 2, 161）。

探鑛及選鑛 但馬の一試掘鑛區に於ける磁力探鑛 藤田義像, 和田正美 兩氏(水曜 6,649), 尾去澤鑛山選鑛の變邉及實績の概姴 野村賢造氏(日 鑛 48, 194), マンガン鑛の浮游選鑛 山口吉郎氏 (日鑛 48, 103), 朝鮮 產金鑛の浮選法 石川留吉氏(日鑛 48, 138), 細倉鑛山泥鑛處理の浮游選 鑛 神田禮治氏(日鐄 48, 186), 浮游選鑛飞於ける鑛物盖の大さについて

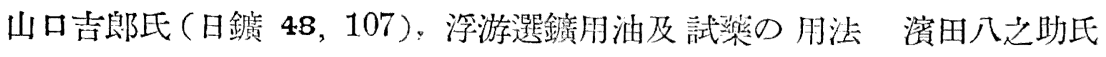
(日鑛 48，116)，フローテーションのメカニズム 高橋芧三三郎氏(日鈸 48， 128), 複雜硫化鑛床の開發飞伴ふ隻先浮選法の缺陷 高橋幸三郎氏(日鑛 48,87), 鑛物のターニシュメントの浮游度に及㴗与影響 山口吉郎氏(日 鑛 48,112), 吹砂充䈊法の實技 小田川達朗氏(水矅 6, 759), 焙燒亞

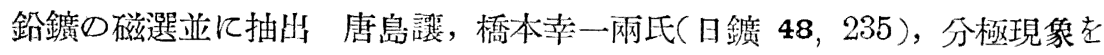


利肘与っ新電氣探鑛法 松原厚氏(地質 39，340)，㾰兒溝鐵山に於ける磁 力探鑛 藤四義象上( 日鑛 48,759), 小型試驗機による浮游逼鑛試驗 前 时孝矩比 日鐼 48,788)。

金銀類製鍊 金の定性的性質と灰吹法 中村喜義氏 (北光 31，28)，金 の電的尔作朋(第2 郝) 木俣泰清氏（日鑛 47，1190)，金の電氣分解，附銀の

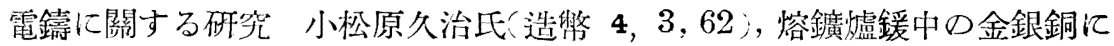
關する研究 浩田哲二郎氏 日鑛 48，475)，鑛石中の金の檢出法 鈴木廝

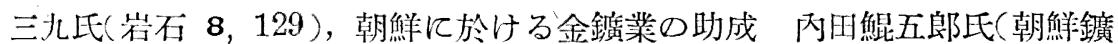
15, 213),

銅，亞鉛及鉛其他の製鍊 タングステン酸化物の還元本衡 中澤良夫， 岡田辰三网氏(電評 19，1651)，鑛烟除害と硫酸工業 三浦彥炏郎氏( 北光 31，22)，本邦各地製鍊所銅鎔鑛爐裝入物の大さに關する調查事項 桂辨 三民(日鑛 47，785)，錫電解製鍊 木村善七比、日鑛 47，966)，監化第一

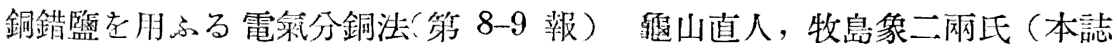
34，1164，1171)，純金屬マンガンの整法 金支濤聲氏(電鋼 8，95)，亞鉛 鑛の焙燒、第 2 報) 硫酸作用上不純物の影響（英交）小川芳樹氏(東北工報 10，215；日化總 4，480), 亞鉛鑛の硫酸化焙燒 唐島讓氏(日鑛 48，243)

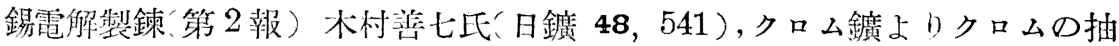
出に關する研究 小山祥氏'東工試 27，(4)1)，マグネサイトを原料として 金屬マグネシウムを製造する一工粦的方法 鈴木庸生, 今富祥一郎，尾間一 彥，永井亮三氏等（日化 35，945)，監化第一銅錯監を用ふるる電氣分銅法(第

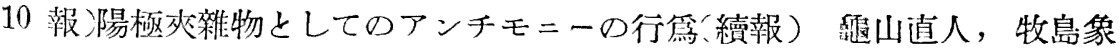
二兩氏(本誌 35，895)，硫化銅鑛冶金爐几於ける蒼鉛の除去 中尾常之氏(探 鈸 10，196)，銅鎔銝爐の調合計算 小浪博氏(日鑛 48，802)，炡燒亞鉛 の抽出に關する研究 (第3 報)不純物の動作 小川㪇樹氏(日鑛 48,683), 
チタ二ウム冶金 前田六郎氏 探䥄 9, 134，156，211，264，264 293),錫 精鑛よりタングステンの抽出試驗 俳藤䏌氏 素除去法の研究 渡㬊俊郎, 森田四郎网氏 (採鑛 10,222)。

純鐵に關する事項 鐵一七メンタイトー硫化鐵系平衡別態圖 传藤知雄氏

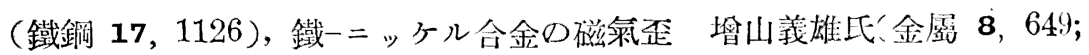
東北理報 I, 20，574), 空中燒入机せる permalloy の高透磁率の原因(丢 文) 本多光太郎氏(東北理報 I, 20,731), 壓縮せる鐵粉末の電采抵抗と その盜度係數 西山善次氏 (金屬 9，139)，氣相存在の三元系老誘盖して $\mathrm{Fe}-\mathrm{N}_{2}-\mathrm{H}_{2}$ 及 $\mathrm{Fe}-\mathrm{C}-\mathrm{H}_{2}$ 系を論才～西村秀雄坁(水曜 6,735), 鐵一炭素モ゙リ゙デン系平衡狀態圖(I-II) 武井武氏（金屬 9，79，142），鐵の機

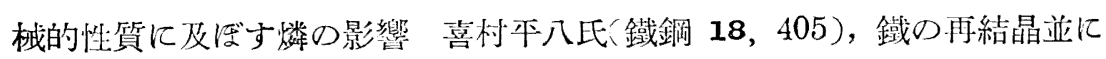
單絬晶生成 後藤付一氏 (旅工菓 19, 1), $\mathrm{Fe}-\mathrm{Fe} \mathrm{H}_{3} \mathrm{C}-\mathrm{FeS}$ 系平衡狀態圖 （英支）佐藤知雄氏(束北工報 10，453），電着せる鐵-ニッケル合金の X線的研究(英支) 岩瀨展三, 那須信行兩氏(Bull. C.S.J.7, 305), 物質 の變態により生ホる結晶軸の方向變化に關する X一線的研究（續報）鐵 庄司彥六氏(金屬 9, 292)。

鑄鐵に關する事項 高揮發分道內石炭に依る製銑 川名正名氏(鐵鎆。17, 923)，八正鎔銑嘘改造に關する報告 目黑斌氏(製鐵 120，145)，鎔銑煴 用骹炭と乙の規格 黑田泰造, 伊能泰治网氏(製鐵 120,165 ), 釜石鑛苝所 鎔錿爐瓦斯除塵灰より加里包收試驗甲四裕, 山本神二郎兩氏(本誌 34, 1131), 固體岑素材による砂鐵の還元に及代す一酸化荻素及炭酸瓦斯の影

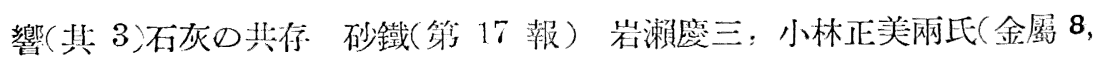
355), 砂鐵の研察(I-III) (英文) 岩瀨鹿三, 福岛政治, 齊藤雄治, 小林 正美，箕作新六氏等（東北理報 I，20，489；日化總 4，481，5，25，24， $270)$, 電氣爐による再製鑄鐵の製造 佐野正夫, 乘岡理雄网氏 
(11) 1), 砂鐵の顯微鏡的組織 砂鐵(第 20 報の 1-2) 齊藤雄治氏(金屬 8，535，608), 北海:道及朝鮮褐鐵鑛の還元率比較 井上克己氏(九工董 6, 157 ), 砂鐵に含有せるヴナヂウムの還元 向山幹夫比(䥫銅 17，1005), 普 通鐵鑛と砂鐵の還元比較 砂鐵(第 19 報) 福島政治氏(金屬 8,457), 砂 鐡の顯微鏡的組織 砂鐵(第 20 報の 3) 齋藤雄治氏(金屬 8,634), 熔鑛 爐の爈壁煉瓦の腐飿 淺时讓, 林田二男兩氏(鞍山鐵 41, 43), 窒化チタン 飞關する 2〜3 の實驗 砂鐵（第 21 報）川口卯三郎氏(金屬 9，131）， 本邦に於けるコットレル電氣收嶎法始近の發展 志賀潔上(然協 10，1367）， 鞍山鐵鑛の還元(2) 三田正揚氏（鞍山鐵 41，1)，製鐵，製鋼用原料の熱 分析とその品位 田所芳秋氏(製鐵研 11，(5) 1)，七メンタイトの構造 志村繁隆氏(東工紀 20，1；日化總 5，26)，コットレル法に上る製鐵鎔鑛 嘘瓦斯の除塺 志賀潔上(鐵銅 18，206)，鑄鐵配合中のクロム 益田義三 氏(北光 32,34), Perowskite $\left(\mathrm{COaO} \cdot \mathrm{TiO}_{2}\right)$ \& Titanite $(\mathrm{CaO} \cdot \mathrm{TiO} \cdot 2$

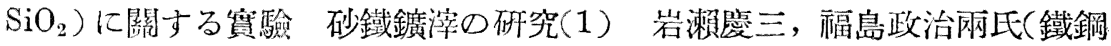
18, 219; Bull. C.S. J. 7, 91; 東北理報 I, 21，114), 砂鐵鑛の濕式處 理に關する研究 前田六郎氏(鐵鎆 18,119)，黑心可銀鑄鐵の熱特性 菊

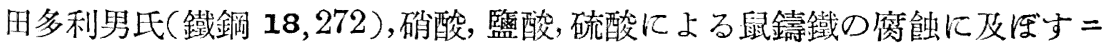
ッケル及銅の影響 山本洋一氏(電銅 8，79），砂鐵の電氣熔融製鍊に於け る各種還元劑の效相に關する研究 向山幹夫氏(鐵鋼 18，(5)附 2 ), 久慈 海綿鐵よりヴナヂウム鋼製造の牛工業的赛驗概要 上野建二郎氏(鐵銅 18 , (5) 附 13)，砂鐵製鎳の實地操業 小塚壽吉氏(鐵鋼18，(5)附 20)，スポン ヂ鐵の組織的狀態と其製鍊法の考察 梅津七藏氏(鐵銅 18，(5) 附 23), スポンヂ鐵の製造 岩瀨慶三氏(鐵鋼 18，(5) 附 29)，瓦斯還元法に依る スポンヂ鐵の製造 嘉村平八氏(鐵銅 18，(5) 附 30), 貧鐵銅としての砂鐵 利用 長谷川熊彥氏(鐵銅 18, (5) 附 36 ), 鎔鋾爐瓦斯の清淨 川上大輔氏 


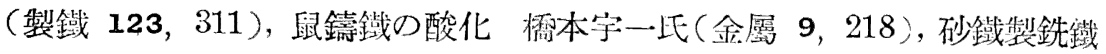

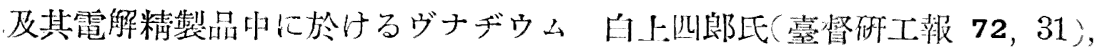
洞岡鎔鑛爐に於ける發生及消費熱量計算 野田庭术氏(製鐵 124，425)，製 鐵所に於ける剩蜍瓦斯 大野宏纸彆鐵 124，433)，低級チタン酸化物の 鑛滓に及弫す影響 坦內富士雄氏鐵銓 18，589)，七メンタイトの絬晶構

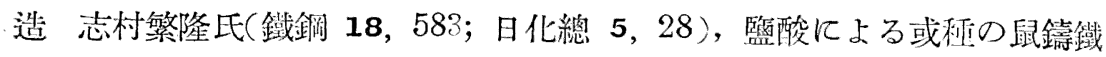
の腐蝕後の表面の空氣中に於ける發熱現象，附鼠鑄鐵の監酸による腐蝕に 及将与銅の添加の影響 山本洋一氏(理研報 11，834），冶金用蓄熱室設計 或は操業に當り必要なる考察と計算 福井㒜氏(鞍山鐵 43，263), 製鐵所 に於ける A. I. B. 式粉鑛燒結に就て 村上敏)雄氏(鐵鋼 18,663), 砂鐵 鑛㳯の研笁(I)ペロースカイトとチタナイトに關する賽驗 砂鐵、第 23 報)

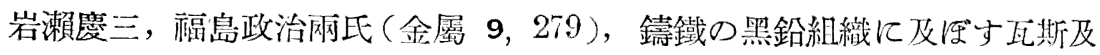
熔解溫度の影響，附鑄鐵の炭素定量 由中清治氏(製鎆 18，690)，砂鐵の 燒結に及匢与二酸化チタニウムの影響 加藤武氏( 水曜 6,837)，八幡製 鐵所に於ける鎔鑛爐瓦斯, 發生爈瓦斯, 骸岑爐瓦斯使用上に於ける被害豫 防法 氏岡正行氏(鐵鋼 18，861), 電氣製銑に使用せらる〉各種還元劑と 銑鐵組成の關係 向山幹夫氏(電銅 8, 398), 制鐵, 製銅用原料の熱量分 析とその品位 由所芳秋氏(製鐵 121，52)，低珪素銑製造法の研究 本川 良彥氏(製鐵 123，331，124，391)，傛鉷爐瓦斯の利用及配付 海野三朗

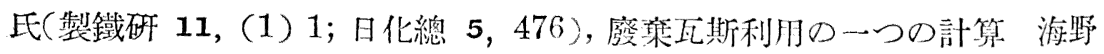
三朗氏(電鎙 8，419)。

鋼に關する事項 富士式平爐 富山英太郎氏（製錩 17，928）, 燒入炭

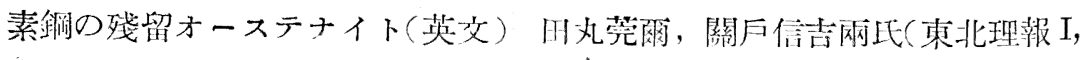

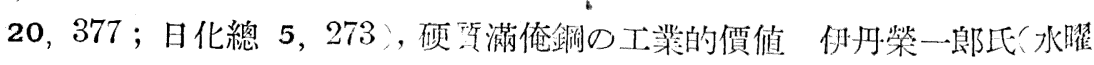

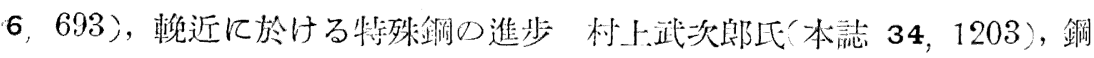




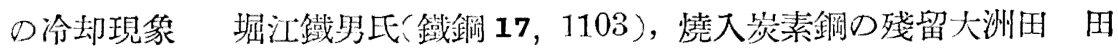
炕莞爾, 關戶信吉兩氏(金屬 8，595; 日化總 5，273)，鐵鋼中コバルトの

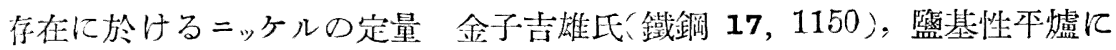
低る低岑素銅の製銅法 小平勇氏(製鐵 121，239)，波來土の顯微鏡的組 織(英文) 三上美和吉氏(束北理報 I，20，710)，久慈海綿鐵よりヴナヂウ

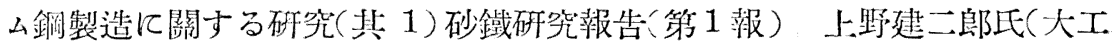
試 12，(14）1；日化總 5，475)，固態滲炭齌の滲炭力減袁 石澤命知氏

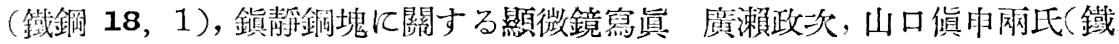
鋼 18，51)，タングステン鏰に於ける針状地鐵の生成(英文）村上武次郎， 武田修三网氏(束北工報 10,269), 二ッケル珪素鋼 金支濤㿦氏'電銅 8 128)，低ク口ム鋼の研究 森寺一雄氏(製鐵 122，293)，耐酸銅の探求 多賀谷正義氏( 鐵鏰 18，131)，高ク口ム鋼の變態點及組織に及压す珪素の 影響(英文) 村上武次郎，横山均次网氏(東北理報 10，245；日化總 4,

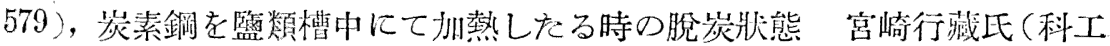
7, 303), 燒入研究胉自記膨脹計，附岑素鋼に於ける結節奘吐粒洲の生因 佐藤淸吉氏 $($ 金屬 9，174；日化總 5，369)，ク口公鋼の組織成分 村上武 次郎，初田數衙兩比鐵龬 18，399)，モリブデン銅に於けろ强磁性炭化物 （英文）武井武氏(東北理報 I，21，127; 日化總 3，489), 滿俺 $1 ２ .5 \%$ を 含む炭素鋼の性質に及壮すモリブデンの影響 金支濤聲氏(電鋼 8，306)， 窑化鐵に含まる〉原子狀水素 任藤俊一氏(日化 53，457; 日化總 5，156)， 2 種の窒化鐵の關係 佐藤俊一氏(日化 53,466), 䝁素硬化用鋼の炭素量

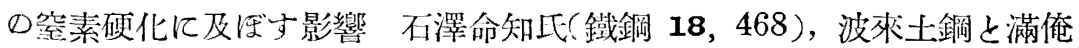
金支濤聲氏(電銅 8，249) 低岑素錩の炭素含有量と抗張力並に延伸率との 關係 足立魀次, 長井峻一郎网上(製鐵 123, 357), 炭素鋼の再燒入 七尾 正三郎氏（金屬 9，197），鹽基性平爐鋼塊の材質的特性 小平勇氏（鐵銅 
18，548)，ニッアルークロム鋼の炭素量と變態點及硬度の關係 村上武次郎, 三上美和吉网氏 $($ 金屬 9，225)，タングステン鋼とモリブデン銓との類似

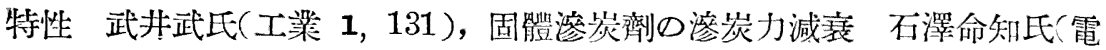
銅 8, 271，335)，炭素鋼の A, 點以下の燒入時效硬化現像 山田良之助， 橫山均次网氏(束工學報 1，131；日化總 5，478)，製鋼朋各種ドロマイト の品位の判定とその應用結果 田所考秋氏 製鐵研 11，(6) 1), 外輸の材 質的研究 小平勇, 森寺一雄网氏 (製鐵研 12, (1)1), 鋼鑄物製造に於け る經濟的考虑(第 1 報)電氣製鋼費及鑄造費 才川直雄上( 鐵銅 18，821)， 銅及銑鐵中の硫黃分析法 十河浩氏( 鐵鋼 18，981)，2 種の空化鐵の關係 佐藤俊一氏 (鐵銓 18,942;Bull. C.S.J. 7，315)。

アルミニウム及其合金に關する事項 海水に對して耐腐蝕性なる新輕合 金クルミン(Chlumin)と既知輕合金との比較 飯高一郎氏(鐵銅 17，944； 日化總 5, 318), 輕合金シルミン 小林虎男氏 (旅工荣 7, 1), アルミ二 ウム輕合金に及活す種ヶの改良劑の影響 伊丹榮一郎氏(鐵鋼 17, 1288)， 金アアルミニウム采の X線による研究（第 1-2 報）加藤述之氏 851)，アルミニウム一銅一珪素合金の試製及その性質の硼究 後藤正治，福 田傎一, 堀口貞雄, 永井恭爾氏等（航空研報 73，145），海水に對して耐 蝕性をる新輕合金 Chlumin と既知輕合金との比較（第 2 報）飯高一郎氏 (鐵鏰 17，1336），アルミニウムの硝酸中に於ける腐蝕試驗 東尾伸吉氏 (住友研 1, 18), 食鹽水中に於けるアルミニウム輕合金の腐蝕 五十嵐勇

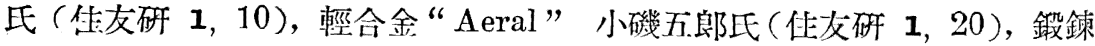
アルミニウム合金の比較試驗 松田孜，東尾伸吉，田村正郎氏等( 住友研 1，1）アルミニウムを主成分とする $\mathrm{Al}-\mathrm{Cu}-\mathrm{Fe}$ 合金の組織 山田珪次， 中村黄兩氏(理研報 11，815)，熔融眐合金，銅合金及鋞鐵の粘度測定 齋 藤大吉, 松川達夫兩氏 (京工紀 7, 49), ヂュラルミンの陽極的酸化 稻村 
賢三氏 住友侀 2,92，アルミニウム合金の腐蝕試驗と其一考察 小磯五 郎氏(住友研 2，105)，アルミニウムを主成分とするアルミニウム一珪素鐵合金系の研究 西村秀雄氏

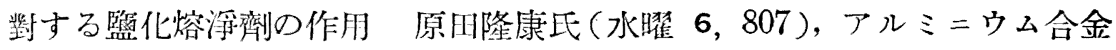
の瓦斯合藏に及代す熔僻方法の影響 伊藤孝吉氏 (金虽 9, 296)，燒届に よるヂュラルミンの變化 松田孜氏(住友研 2,80 ), デュラルミンの性質と 組成との關係 松时孜氏( 住友研 31，134)，燒大世る棘合金の成熟及燒杘 の機構 武內武夫氏 抗張試驗 田村正郎氏(佳友研 3,159), ヂュラルミン, プロフイルの露天 腐強試驗 稻村賢三氏(佳友研 3, 146)。

其他の金屬及合金に關ずる事項題鍮上り亞鉛の蒸發に及深す他の金屬

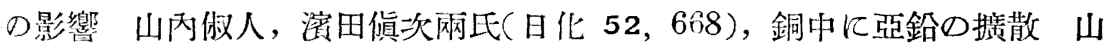
內俶人氏 (日化 52，651)，マンガン，ニッケル或はコバルトを含有する $2 \sim 3$ 合金の㠜固收縮 ·英文) 本多光太郎, 松山芳治, 磯部矢次氏等(東北

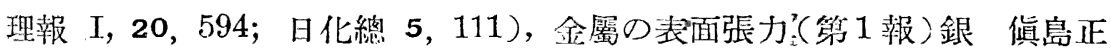
市, 石井正志, 作井誠太氏等 (理研報 10，1061），金屬の磁氣係數と內部 歪の效果 本多光太郎, 清水與三松兩氏 金屬 8，565; 日化總 5，331；， 水銀線の超微細構造(英文) 村川潔氏( S c. P. 16, 243), 高溫度に於ける Co 單結晶の磁化 本多光太郎, 增本量雨氏(金屬 8,583; 日化總 5, 421), 金屬元素 $\mathrm{Cr}, \mathrm{Mn}, \mathrm{Fe}, \mathrm{Co}, \mathrm{Ni}$ 及J゙ $\mathrm{Cu} の \mathrm{KX}$-線吸收スペクトルの多重構 造(英文) 澤田昌雄氏(京理紀 A，14，229），アルカリ金屬薄膜の光電性 質(英文) 淺尾莊一郎, 長岛躬行兩氏(マツダ 6,101), 鉛の變態の有然 (英文) 枝和四郎氏(東北理郝 I, 20,715; 金屬 9, 125)，有機物）存在 に於ける諸金屬の反應“英文) 箱守新一郎氏(東北理報 I，20，736；日化 47，92)，コバルトークロム系平衡狀態圖 松永陽之助氏(金屬 8, 549), マグ 
ネシウム合金用熔犁の研究 遠藤岸郎氏(金屬 9, 24), 金屬つラヂオグラフィ

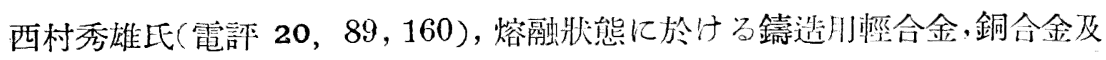
鑄鐡の粘性(補遺) 松川達夫比( 鐵銅 18, 144), 銅-錫系 $\beta$-固溶體の共析

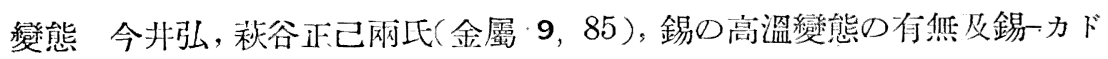
ミウム合金の平衡圖（英文）松山芳治氏(東北理報 I, 20，649；金屬 9, 1; 日化總 5, 443), 新熱分析法に依る 2 3 のコバルト合金の硎究, 2〜3 のコバルト合金(符1 啹) 橋本宇一比(金屬 9，57)，酸及アルカリ溶液中 に於ける銅の腐蝕 稻村賢三比(仿友路 1, 36), 2 種金屬間の摩擦による 起電力(英文) 拔山大三氏(数物 III, 14,93), 金屬マンガンの酸化還元 平衡 靑山新一，岡好良丽氏(日化 53，417), 硫酸亞鉛の水溶液より監鉛 を電着乩しめる場合の電位差 石原金吾, 梅津捷夫兩氏 (金屬 9，244）， 白色金(ホワイトゴールド)の乾式試金 岡田侮一郎氏(造幣 4, 72), 銅一 錫系に於ける變態の本性(第 2 報)(獨文) 今井弘, 萩谷正已㒳氏（旅工紀 5, 77), 活字合金の研觉(第 7-9 報) 青木信利, 池田次郎网纸(內印 22, 1，19，57), 活字合金の研究(第 10 朝)活字合金として必要なる條件並に 其の鑄造中に於ける諸事項に就ての考察 青木信利氏㐫印 22,61), 活字 合金の研究(第 11 報)活字鑄造中に生亦る鑄㵏並に其合金回收 靑木信利, 脇昌次郎兩氏(队印 22, 85), 活字合金の研究(第 12 報)鉛, アンチモン, 錫合金の熟膨脹灭密度 靑木信利, 池田二欠郎兩氏(內印 22,97), $\mathrm{Ni}-\mathrm{Zn}$ 二元系平衡狀態圖 由丸莞爾氏(理研報 11，772），マグネシウム合金の熱 傳導率及電氣傅導度 菊地麟平氏(金屬 9,237)，マグネシウム合金の食

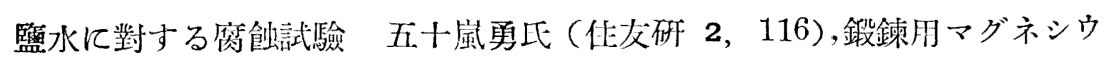
么輕合金 石田四郎氏 鐵銅 18,705), 高溫度に於ける金屬の酸化速度 深 川庫造氏（鐵銅 18，843），合金の時效硬化に及ぼす磁氣處理の影響 松

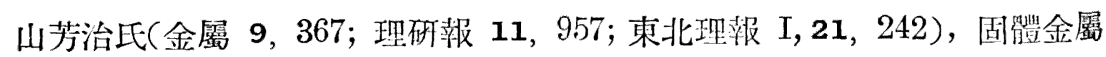




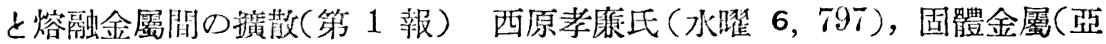
一鉛銅系）の湖散速度に對する溫度の影響(英文）俣野仰次郎氏（京理紀 A，15，167)，銅中に亞鉛の擴散(英交) 山冈俶人氏(京理紀 A，15，67)，

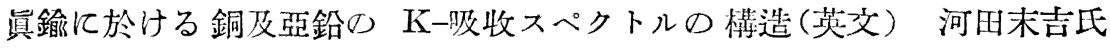
(J.J.P. 8, 51), 化學工桠女合金 山村銃吉氏 (朝鮮鋌 15, 145)，三成 分合金の異相平衡 $(\mathrm{I})$ 中川維則氏(明治專報 3，(3) 157), 銅を主成分と せる合金の包晶反應による結晶微細化の現象 朝戶順氏(金屬 9, 392)， 鉛ーアンチモン合金 柳澤光治, 圖師督兩氏(東商 21，61), 鉛-アンチモ ン合金江錫の添加の影響 柳㶔光治，圖師督雨氏(東商 21，71)，マグネ シウム合金の炭蝕(第 1-2 報) 遠藤彥造, 森岡進兩氏(金屬 9, 328, 352)， 耐酸銅合金 “ $\mathrm{AR}$ ” の性能 时邊友次郎，小磯五郎兩氏(住友研 3, 128)。 金屬材料及加工 金屬の着色法 盆田義三氏(北光 31，33)，金屬及合 金飞含まる」瓦斯の除去の機構(III) 西付秀雄氏(水矅 6,691)，燒針脆 性 蒔田宗次氏(鐵銅 17，1042)，小銃彈老以てする防楯用鋼の抵抗測定 本多光太郎，竹前源藏，疫邊直行氏等(金屬 8,619; 鐵銅 17，1047)，銅 の波勞及歪の檢出法 藤井寬氏(水秏 6,679), デュラルミン鈑の鍍金及海

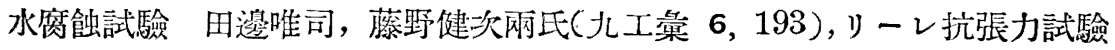
機 近藤清治, 宮川愛太郎兩氏（窵協 39，729）, 鑄造金屬及合金破斷面 の一型 飯高一郎氏(P.I.A. 7, 337)，鑄鐵製口ールに及伎す製造爿沉 の影響 谷口光平氏(製鐵 121，224；製鐵研 11，(3) 1)，常溫加工に上 る金屬の凮性率の變化 河合匡氏. (金屬 9,38), 旅順水道鐵管窝蝕調查 長谷川熊彥, 澤口留藏网氏(旅工梏 10,1), 古代支那貨慜の化學的研究(第 2 報) 道野鹤松氏 (日化 53, 100)，アルミニウム酸化皮膜生成の條件と 機構 瀨藤象二, 宮田聰兩氏(理研報 11, 317), 鍍金の物理的性質 村上 透氏(日化工 16，44)，ク口ム鍍金に於ける陽極 石田武勇氏(科工 7,27)， 


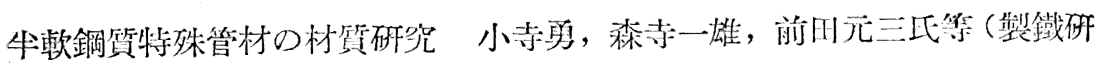

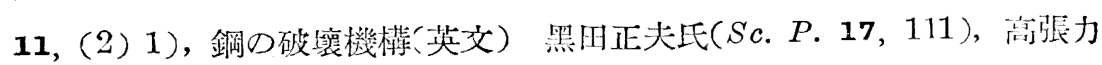
鋼板のブリスター 森寺一雄, 森下傎网氏(製鐵研 11, (4) 1), 鑄造時に 於ける中子の內部壓力 內藤逸策氏 (鐵鎆 18, 149), 鑄鐵の成分と影(引

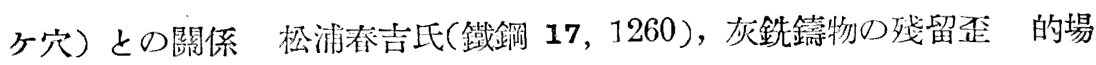
幸雄, 岸本浩兩氏 金屬 9，74), 鐵及銅の表面硬化 小田基礎氏(科工. 7, 21)，超高速度工具材料 “タンガロイ”の製法と應用の概略 中村素氏(電 化 49-50，114)，常溫加工金屬の彈性率に及卧す影䅧(英交) 河合匡氏

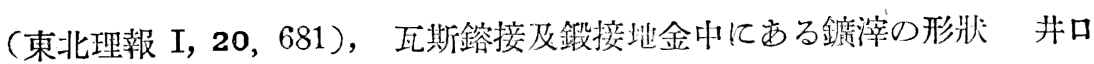
庄之趿氏(鎔接 2,84), 電弧鎔接に及结す瓦斯の影響 井口庄之助, 岡田 資兩氏(鎔接 2,151)，瓦斯鎔接に使用するカーバイトの性質 大田三吉 氏(鎔接 2，15)，アルミニウム及其命金上にニッケルの電鍍 持田德彥氏

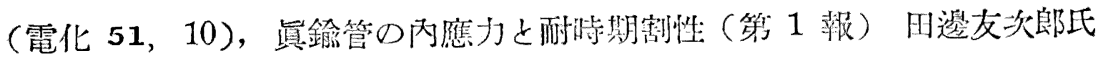

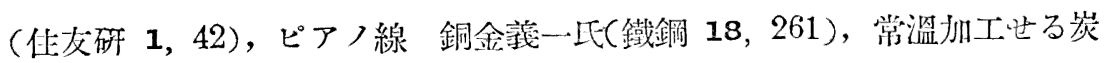
素鋼の $\mathrm{A}_{1}$ 以下の燒䤥による機械的性質の變化 絹川武良司氏(住友研 1 , 26)，薄鋼板の壓延 須永已代次氏(鐵鎆 18,346), シートバ一孟延の理 諭之實際 川本良行氏(鐵銅 18，356)，電热線の材質 井上克己氏(日鑛

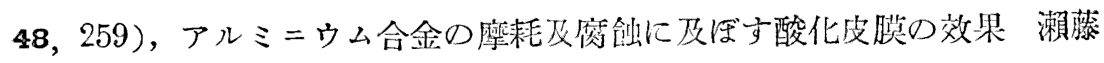

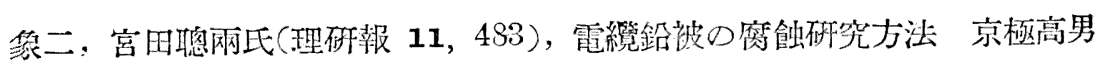

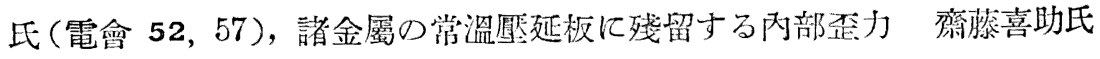
(金屬 9,207), 錻力板の鍍金作滗 伊藤正夫氏(鐵鋼 18,378), 極印下 地燒鈍方法の改良 大山高良氏(造幣 4,75)，堂漂に於て發見せられたる 五十錢價货，服部武彥，山崎稔兩氏(璐督研工報 76, 1), 航空機用薄肉鋼 管材としてのクロムーモリブデン鋼 絹川武良司氏(鐵鋼 18,563), 電氣 抵抗熔接 岡本起氏(鎔接 2, 291), 厚板の熔接 田村元治氏 (鎔接 2, 
304), 東洋古代金鷵器の化學的研究（第 1-2 報）道野鶴松氏(日化 53, $744 ， 748)$, 损り加工が金屬の比重，大きさ(Dimension) 並に電氯抵抗に

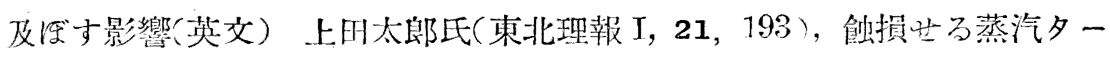
ビン賈の一例に就て 田村精一氏(日鑛 48,691), 鑄鐵及青銅鑄物の電氣 鎔接 作及木新太郎氏(鎔接 2, 225，308), 眞鍮管心队應用之耐時期割性

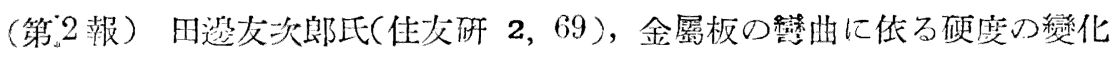
儿就て(英文) 小久保定次郎比(東北理報 I，21，256)，錫鍍及亞鉛鍍 相

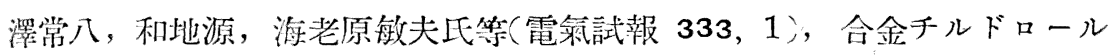
の研究 谷口光平氏(鐵鋼 18,952), 續本邦鏟物史の研究 石井健一郎氏 (電鋼 8, 207, 256, .315, 363), 特殊アルミニウム県鍮復水器アルブラッ ク(Albrac) 田邀友次郎, 小磯五郎兩氏(住友研 3, 122), 航空機用銅管及 鋼板材としての不錆銅（第 1 報）細川武良司氏(住友研 2,53 ), 衝撃に 龂する合金鋼の 2〜3 の性質（其 1) 衝揧屈曲試驗に於ける力變形一曲線 宝井喜治馬氏(鐵銅 18，922), 据り加工が金屬の比重, 大さ並に電氣抵抗 几及估す影響上四太郎氏(金屬 9，419), 試片の屈曲に上る硬度の變化 小久保定次郎氏 (金屬 9, 447 ，鋼索用針金の繰返彎曲䆩驗 水田準一氏 (日鑛 48，891)，ロープストランドの壽命に及将す諸應力 水田準一氏氏日 鑛 48,899), 鐵錆の研究(其 1-2) 遠藤彥造比(電鋼 8, 57, 109), 錙接

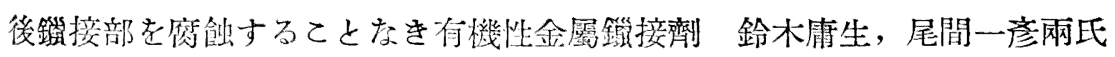
（理研報 11，1050），航空機用鋼管及鋼鉱材としての不錆鋼（第 2 報）絹 川武良司氏(住友硎 3，163)，鐵板の表面に塗布せる亞鉛の結晶（英文） 松永義明氏(京理紀 A, 14, 263)。

\section{9. 陶磁器, 硝子及耐火材}

粘土の性咓 小林久平, 山本研一兩氏（本誌 35,182 ) は粘土類のア 
ルカリ溶液に對する溶解度を測定し, 稀アルカリ溶液に溶くる物質は粘土 の種類に低りて大洷あり，且カォリナイト族粘土は濃溶液に對しても溶解 量小なるが故に之に依りて $\mathrm{SiO}_{2}$ 及 $\mathrm{Al}_{2} \mathrm{O}_{3}$ の結合狀態を略推察し得と結

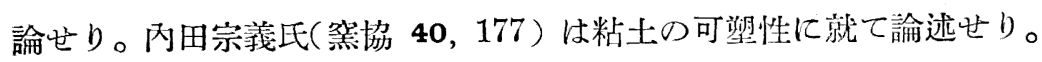

淘汰分析 杉原清一氏(鐵道省土質調䄳委員會城告 2 ，163) は從來の土 壤淘汰器を改良し其實驗成績寺示せり。

粘土の利用 松井七郎氏(臺督研工報 83,1) 岋臺灣大坑﨎粘土に就て試 驗し良質炻器粘土なるを確めたり。鳥取縣商工獎勵館（昭和 6 年度割業部 業務功程報告書 20$)$ は昭和 6 年 5 月八頭郡八上村に 9 月氣高郡明治村に 朱泥土を發見吕り。同館 (同 10 ) は隱岐産珪澡土と瓦土との混合物に就て 試驗せり。

滑石 伊藤集忬氏(マツダ 7，8) は滑石の電氣䋓縁性老测定し $\mathrm{Al}_{2} \mathrm{O}_{3}$ の添加は絕緗度を低下し $\mathrm{CaO}$ は之を增大寸と結論せり。

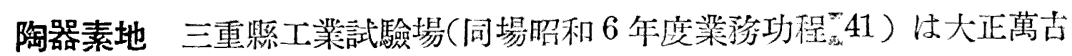
燒の改良を研究し SK6a 內外の素地として適當なる配合の範圍を求めた

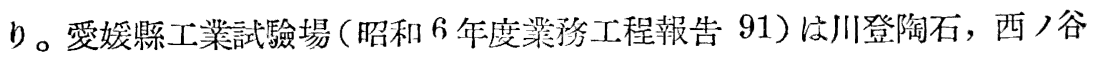
粘士及燒粉より成るテラコッ夕素地及之に適する艶消粗牛豊消釉を報告せ り。相犲文吉氏(陶泉 7, 17)は天草石蛙目土及長石の陶器素地土を試驗し 良好なる配合比を求めたり。

マイカレックス 玉术文男, 利根川武兩氏(大工試 13，(4) 1)はマイカ レックスの良好なる素地製作條件を探求せり。

磁器石炭燒成 愛媛縣工.業試驗場(昭和六年度棠務工程報告 91) は燃料 節約に關する硂部磁器の石炭燒成試驗(其 3 )を發表せり。

化粧土 島根縣工業試驗場( 昭和 5 年度業務報告 56 ) は天草石及島根縣 水上土を以て白色化粈土調製の試驗を行へり。 
石灰喟陶器秞 安宅吉太郎氏(神工陚 2,6) はスラーリーを混じたる低 火度粙に就て研究せり。

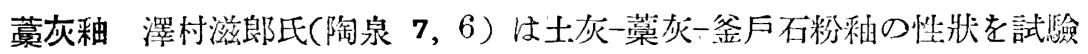
し，之酒化鐵 $26 \%$ を含有する鬼石を配合して種々の釉を得たり。鳥取

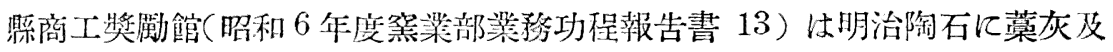

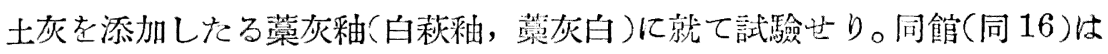

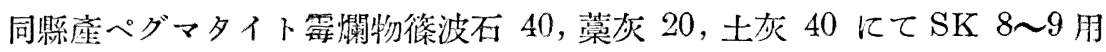
菜灰粙在得をり。

島根縣工業試驗場 (昭和 5 年業務報告 59 ) は布志名燒火前部及石見燒最

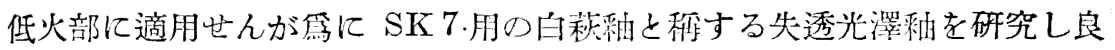
好なる結果を得たり。

色釉 島根縣工栄試驗場(同 68) 以布志名燒火前部用色釉に就て研究し, 長石合成土灰珪石にて SK 6 7 用乳白不透明光濢橎を得, 之洋色劑在 加へて種从の色租を調製せり。愛媛縣工業試驗場（昭和 6 年度業務工程報

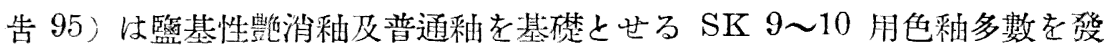
表せり。

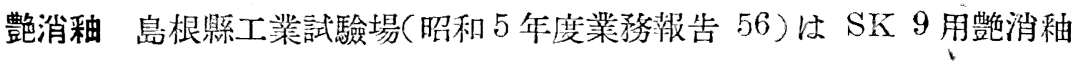
飞就て研究し，來待錆石を使用せる黃色釉及普通原料の白色釉を發裴せり。

瓦橎 鳥取縣商工獎勵館(昭和 6 年度等業部業務功程報告書 1 ) は來待鍀

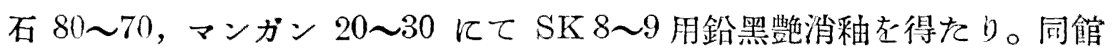

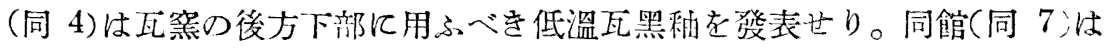
SK 9 用綠色瓦釉老報告せり。塚本豐彥氏 (岐阜縣陶磁器試驗場昭和 6 年 度澲務報告 65) は $\mathrm{K}_{2} \mathrm{O}-\mathrm{CaO}-\mathrm{MgO}-\mathrm{ZnO}^{-} \mathrm{Al}_{2} \mathrm{O}_{3}-\mathrm{SiO}_{2}$ 釉化酸化ク口ム又 は監基性炭酸銅を加へて SK 5a 用瓦嬏索得たり。同氏(同 88)はコロフォ ニウム假漆及レトルトカーボンを以て吸水性をき廢㳑燻燒瓦を商品化する 
方法を發表せり。

結晶嬏 永塚樂治, 谷川節二, 井上美邦三氏(陶泉 7,2) は亞鉛結晶釉

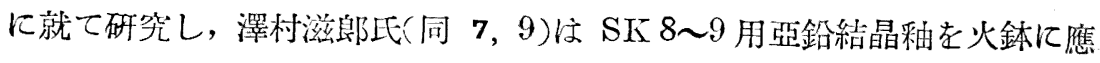
用したる結果を報告せり。島根鲧工栄試驗場（昭和 5 年度菜務報告 63 ) は 基礎釉に對する $\mathrm{TiO}_{2}$ 添加量衣決定此り。

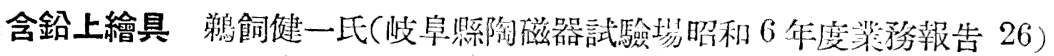
は含鉛上繪具の硏究を繼續し呈色劑の調製法並に之に適する 650 及 $700^{\circ} \mathrm{C}$ 用融劑の原料配合籍園圭示比り。

セレン火赤 榎本修二氏 (工業 1，122) はセレン火赤は $\mathrm{CdCO}_{\dot{0}} 60$ ～

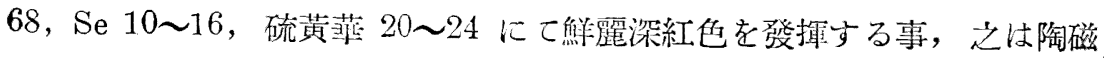
器の上繪具として使用し得へく其融劑としては $0.70 \mathrm{Na}_{2} \mathrm{O} \cdot 0.13 \mathrm{PbO} \cdot 0.17$ $\mathrm{ZnO} \cdot 1 \cdot 40 \mathrm{SiO}_{2} \cdot 1.40 \mathrm{~B}_{2} \mathrm{O}_{2}$ が優良なる事と報告せり。

意匠陶磁器試臨所以意匠圖案研究應用試作品集說明書（昭和 7.3）を 發行し, 各試驗作品の原料及製作法を必說明卡り。

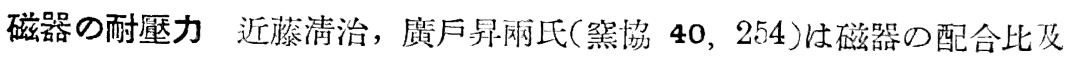
燒成溫度と耐壓力との關係儿就て研咒吖り。

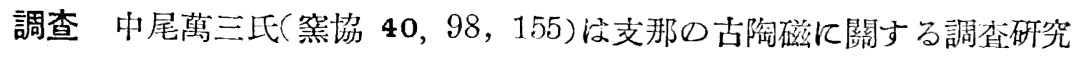
の結果を發表し, 日野厚氏(同, 449) は文獻の調查に位りて唐代に磁器の 存它し事を證し, 服部武彥氏（臺灣事派昭7.1）は所謂嘉義交趾飞就て調

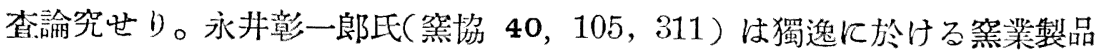
の工業規格を記し, 同, 25 亿瑞典, 諾威の筀紫及原料を述へ，同，721几

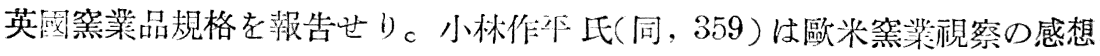
を述へたり。

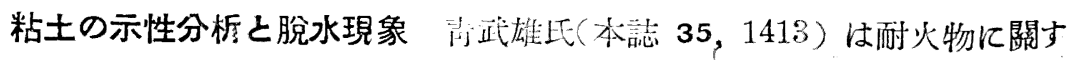
る研等第 1 瓡に於て 8-oxyquinoline に依る新示性分析法を提案し, 第2 2 報 
には磁土に $\mathrm{Na}_{2} \mathrm{WO}_{4}$ 殊に $\left(\mathrm{NH}_{4}\right)_{2} \mathrm{MoO}_{4}$ を添加方特は其脫水が低溫度に て圆滑に完結すと報告せり。

嘘材品啠の向上 加藤孝治氏(爐と嘘材 1，1）忙製鐵所に於ける爐材品 筫の向上に就て恱明せり。

耐火原料の品位 田所芳秋氏(製鐵研 $11 ，(6) 1$ )はドロマイトの比重, 氣 孔度, 微構造, 熱膨脹, 重量分析並にドロマイト加鐵燒成試片の微構造消 化試驗等を行ひ新監基性附火材を使用せる結果を述べたり，同氏(同 11,

（5）1）は變態熱量決定用として加熱曲線法に依る熱量分析法を考案し，之 を石灰石，マグネサイトドロマイト等に應用して興味深を結果を得乥り。

マグネサイトの熱變化 近藤清治, 末野悦六, 吉田博氏等 (空協 40, 422) は大石橋附近主要 6 鈸區のマグネサイトを $1800^{\circ} \mathrm{C}$ 迄熱して其微構造 在研究し, $1200 \sim 1300^{\circ} \mathrm{C}$ 亿て Clinoenstatite は forsterite に無定形の $\mathrm{MgO}$ は periclase に變り 1600〜1700 Cにて forsterite が熔けて poikilitic 棈 造を生ずと結論し，更に添加物の影響を記せり。

耐火煉瓦の熱的諸性質 田所芳秋氏は各種耐火煉瓦の熱的諸性質に就て

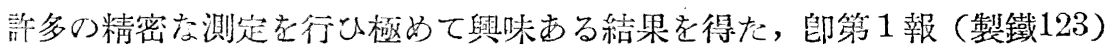
には製鐵所製耐火崃瓦 5 種の普通性質, 熱㑑導率, 熱容量, 比熱嘭脹率測 定の結果を示し，監基性爐材の熱傳導率は溫度の上昇と共に減少する为酸

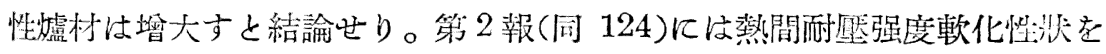
精测し，且之に依て熱間粘性を推定せり。第 3 報(同 126 )には $1500^{\circ} \mathrm{C}$ 迄 の比熱,响氣率, 㴊性率, 破壞率を測定し, 煉瓦を加熱すれば基地部分の粘性

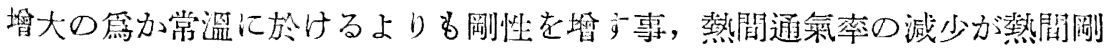
性率の增大, 從て我裂の現集を誘起するに至る事等を述べ,第 4 報(同 127)

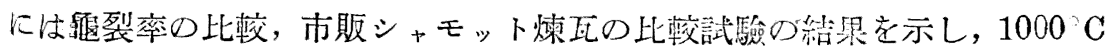

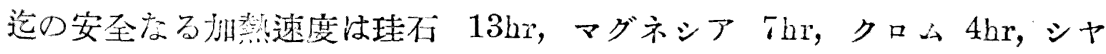




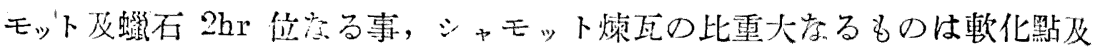

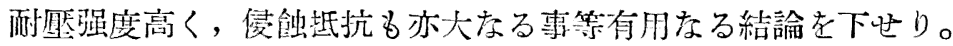

耐火煉瓦の通氮率 田所芳秋氏(墨協 40,691，695) 新案の裝置によ りて耐火㯖瓦 5 種及鐵鑛石 3 樰の $800^{\circ} \mathrm{C}$ 迄の通氣率老测定し，通氣率 は煉瓦の澎脹に際して減少し收泚に際して塯大すと述へ，其他有益なる結 論を下せり。

耐火䱋瓦の吸水率 中本實氏は耐火物に關する敉究第 6 報（本誌 35 , 597 ) に耐火煉瓦の吸水試驗法に就て研究し，同第 7 報(同，1353)には新 試驗法を提案せり。

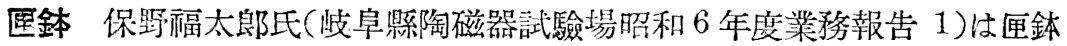
素地土の研究を繼承し良好なる籁圍は燒粉, 粗粉及細粉各 10〜25, 乾燥收 縮 0.5〜1.5, 燒火收縮 $0.2 〜 0.4$ ，見掛氣孔率 18〜24なりと結論せり。

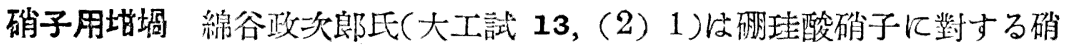
子用坩堝の耐侵蝕詿驗結果を發裴せり。近藤清治, 中辻正信兩氏は硝子熔

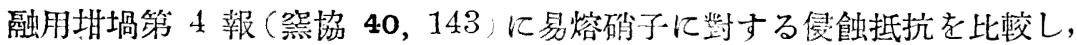
且原料素地土と易熔硝子原料との混合物の耐火度を測定出り。中辻正信氏 （同，511）は硝子用坊佩の形狀及寸法之耐久力との關係を述べたり。

硝子の着色 不破橘三氏は硝子の着色に閵する研究第 2 報の 3 (マツダ

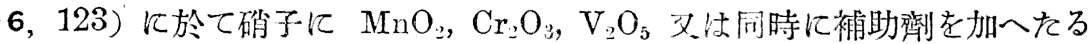
時の着色，紫外線及可視光線の透過曲線に就を㸴究考察し，第 2 報の 4 （同 7，57）に於て酸化ウランは确子中に $\mathrm{U}_{3} \mathrm{O}_{8}$ 及 $\mathrm{UO}_{2}$ を生じ酸化劑を 共用せる時は黃色を帶び溃光强く最短波長大なり。セリア硝子は補助劑の

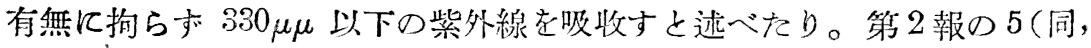
161） 飞は $\left(\mathrm{NH}_{4}\right)_{2} \mathrm{MoO}_{4}$ は黄色を生ずるも酸化劑又は严砒酸を共用すれば

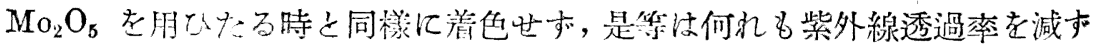


酸化タングステンは還元劑を加へたる時に限り黃又は淡橙色を生じ他の場 合に比し稍短き波長の紫外線を透過すと絬諭せり。

眼鏡硝子 高松亨氏(葖協 40,642)牥內外眼鏡㗂子の品質，化學組成， 屈折率, 耐久性等老示せり。

紫外線透過硝子 不破橘三氏(マツダ 7,19)は紫外線透過硝子の製造法 及性質を示し之には $\mathrm{Ni}$ 在含み近紫外線のみを通すものと $\mathrm{Fe}$ 及 $\mathrm{Ti}$ を避 け其痕跡を 2 價に變へをる紫外可視及赤外線透過硝子とあり，紫外線は $\mathrm{Fe}^{\prime \prime}$ を $\mathrm{Fe}^{\prime \prime \prime}$ に變へるも加熱に低りて還元すと述べたり。安部俊夫氏(同， 99) はバイタランプ試驗絬果を示せり。

硝子の電熱熔融法 近藤清治, 河島千琴兩氏(羔協 40,72) は硝子の電 熱熔融法の內，主として㗂子自體を抵抗とし且炭素電㯃を用ふる方法に就 て研究し, 硝子組成と熔融の難易との關係を求め且原料中に少量の酸化亞 鉛を添加する事に依りて電極に依る硝子の黑變を防止するを得をり。

失透上田清, 松尾直治郎, 並木孝一氏等(旭硝子報 20,1 ) は空硝子 の失透溫度及耐久性を測定し且結晶の鑑定を行ひたり。

硝子原料の陰根 中西健治氏 (本誌 35，467) 沬硝子の石灰原料として $\mathrm{Ca}(\mathrm{OH})_{2}, \mathrm{CaO}$ 又は $\mathrm{CaCO}_{3}$ を用ふる時は互に熱膨脹率及硬度を異にす る事並に此現像は硝子中に殘留する瓦斯の量に基因する事を明汃にり。

硝子の溶解性 上田清氏(旭硝子報 20，20) は熱處理が硝子の表面及瞽 質耐久性を減じ酸性互斯が表面耐久性を菂し水蒸氣は之を減退せしむと述 へ，松尾直治郎氏(同，85)は悹硝子の表面耐久性を測定する方法を比較研 筧せり。森安静太氏 (本誌 35，702) は鉛硝子の水に對する溶解性に就て 研究し, 溶解量は $\mathrm{K}_{2} \mathrm{O}$ 及 $\mathrm{Na}_{2} \mathrm{O}$ の分子百分率の和のみにより決定せずと 結論せり。Oscar Knapp 氏(同，1280) は鉛硝子の溶解性よアルカリ含量 との關係につき在來の研究を比較し其結果の不一致は测定法の不同に因る 
と述べたり。

硝子の電解 安部俊夫氏( マツ名 7,153) は高溫度に於ける码子の電解 及電氣傳導度に就て研究し，且其應用を指摘せり。

硝子の强度 松尾直治郎氏(旭硝子郝 20, 104)は各種空硝子の抗張力及 ヤング率测定の結果を報告せり。

クロム珪酸硝子 山口與平, 中澤治男兩氏 (Bull. C. S. J. 6, 285) は $\mathrm{Cr}_{2} \mathrm{O}_{3}-\mathrm{SiO}_{2}$ 系熔融生成物に就て研究せり。

珐瑯 內田十喜治, 角田秀男兩氏(大工試 12, (15) 1) は曹達鉛, 珪酸, 矹酸より成る可熔性釉の耐酸情を試驗せり。森安靜太氏（篦協 40，167， 248，437，714）は济瑯に關する文献を蒐集したり。

\section{0. セメメント及建築材料}

石灰石 香春三樹次氏(窯協 40,507; は北九州に於ける石灰石に就て記 述せり。

セメントエ業 服部武彥，木村源网氏(臺督硏工彙 7)はセメント工業に 關する調查第 1 編として其沿革を記述せり。

高石灰型セメント 近藤淸治, 吉田博网E( 筣協 40,500)は高石灰型ポ ルトランドセメントの水硬率, 珪酸率, 鐵率が遊離石灰殘留量及强度に及代 す影響を求的，且酸化クロムを以てアルミナの一部を罟捘すれ代著しく强 度を增すととを發表せり。

セメントの色 藤井光藏, 淺岡勝訔兩氏(筌協 40, 148, 291) は少量の マグネシアがセメント色相並にアリット生成に及㾏す影響に就て研究し， ポルトランドセヌントの灰綠色は鐵酸マグネシア生成に依る七リット黑濁 の雼なる事，少量のマグネシアはアリットの生成を良好ならしさる事並に マンガン，アルカリ等はアリットの生成及セリットの變色に對し著しき影 
響なき事を明かにせり。

スラーリーの粘度 小柳勝藏, 笠原賽兩氏(筀協 40, 14) はセメントス ラーリーの粘度に就て研究せり。

炭質の變化 小柳勝藏, 新井孝兩氏 (同, 234) はセメント煰成用石炭の 乾燥粉碎の爲に生する炭質の變化に就て研究し, 粉炭は實筫上發熱量の減 退を見ずと結論山一り。

諸比率 秋山桂一氏 (早應化 16,6) ポルトランドセメントの遊離石灰 消失速度は水硬率に依て最も影響せられ珪酸率鐵率之に次ぐと述べたり。

硫酸分の變化 秋山桂一氏(同 17，19) はポルトランドセメントの燒成 過程に於ける硫酸分の變化に就て研究し, 原料中の硫酸監は燒成中に殆に゙ 完全に分解せらる」もリーング生成の原因となる分解瓦斯は一部 $\mathrm{SO}_{3}$ とな り水蒸氣に依りて硫酸を生じダストに作用して其の $\mathrm{SO}_{3}$ を篔す，コット レル收塵室最後のダストは最す細かく $\mathrm{SO}_{3}$ 含有量も多しと絬諭せり。

レポル窯 F. E. Schmitt 氏(ポルトランド七メント技叝 20，163)はレ ポル䇪を說明し，其成績及經濟的價值を論ぜり。

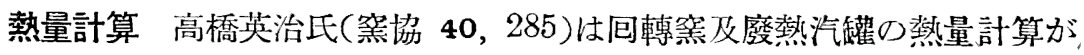
極端に不合理なる絬果に到達する事あるは瓦斯試料探集上の不注意に基因 するを示せり。

電氣收塵 志賀潔氏(同，779)はコットレル電氣收塵法と其應用(其 1)の 題下に先づ理論を記述岌り。

珪酸石灰の乾式合成 永井彰一郎, 秋山桂一网氏は珪酸石灰監の乾式熱 合成に關する㸴究第 2 報(本誌 35,10 ) 亿於て $2 \mathrm{CaCO}_{3}+\mathrm{SiO}_{2}$ 加熱の反應と 生成物の小型强度に就き研究結果を報告し, 第3 報(同, 161 ) には $3 \mathrm{CaCO}_{3}$ $+\mathrm{SiO}_{2}$ を $1600^{\circ} \mathrm{C}$ に $1 \mathrm{hr}$ に熱するb $3 \mathrm{CaO} \cdot \mathrm{SiO}_{2}$ の生成僅少なり, 然る

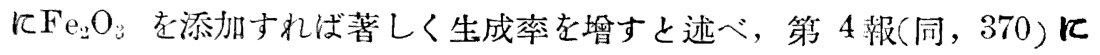




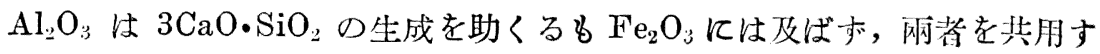
れば $\mathrm{CaO}: \mathrm{SiO}_{2}$ 比は 2.83 几達すと結論せり。

$\mathrm{Cr}_{2} \mathrm{O}_{3}$ の作用 近藤清治, 茂木今朝吉雨氏( 䇺協 40,559) は $3 \mathrm{CaO} \cdot \mathrm{SiO}_{2}$ の合成に於ける $\mathrm{Cr}_{2} \mathrm{O}_{3}$ 及 $\mathrm{Al}_{2} \mathrm{O}_{3}$ の影響老研究し, $\mathrm{Cr}_{2} \mathrm{O}_{3}$ は恐らく $3 \mathrm{CaO}$. $\mathrm{SiO}_{2}$ と固溶體を造りて著しく强度を菂すを結諭せり。

アルミ酸石灰 近藤清治, 山內俊吉兩氏はアルミ酸不灰に就て研究し第 1 報(䈍協 40,81) 亿忙 $3 \mathrm{CaO} \cdot \mathrm{Al}_{2} \mathrm{O}_{3}$ は $1540^{\circ} \mathrm{C}, 5: 3$ 化合物は $1450^{\circ} \mathrm{C}$, $1: 1$ は $1600^{\circ} \mathrm{C}, 3: 5$ は $1700^{\circ} \mathrm{C}$ にて略完全に化合するととを示し,第 2 報 （同，87）には失透物の微構造及屈折率を精測し $3: 5$ 化合物の 屈折率は $\omega=1.621,5: 3$ 化合物は二軸負結晶 $\alpha=1.665, \beta=1.660, \gamma=1.645$, 其玻 琌は屈折率 1.612 にして共に Rankin-Wright の研究と一致せざる事を示 し，第 3 報(同,212）には水和作用の過程を觀測し生成結晶には $\omega=1.498$ $\varepsilon=1.507, \omega=1.524 \varepsilon=1.506, \omega=1.535 \varepsilon=1.511 の 3$ 種あるを明かにし 且 $\mathrm{Al}(\mathrm{OH})_{3}$ ゲルの生成順序を示せり。第 4 報(同, 349) 飞は凝結時間, 凝結に件ふ溫度の上昇及小型耐巽力を報告せり。

珪酸石灰の常壓水熱合成 永井彰一郎氏は珪酸石灰監の常㲀水熱式合成 飞關する研究を續け其第 3 報 (本誌 35,413 ) 飞は $\mathrm{CaO}$ 及 $\mathrm{SiO}_{2}$ の $1: 1$ 及 $3: 2$ 配合物を長時間加熱せる結果を揭げ $3: 2$ 配合物は短時間加熱女等

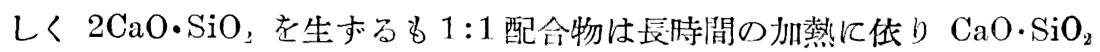

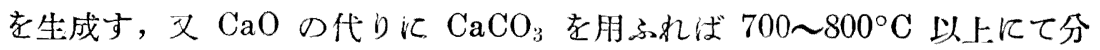
解したる後化合し生成物は變ら和と絬論せり。第 4 報(同，804)には $\mathrm{Ca} 0$. $\mathrm{SiO}_{2}$ が炭酸曹達液に溶けざる性質を利用して之を分别定量する方法を 考案し, 配合物 $\mathrm{CaO}+\mathrm{SiO}_{2}$ の常埾水熱物中には溫度及時間と共に $\mathrm{CaO}$ $\mathrm{SiO}_{2}$ が漸增し $3 \mathrm{CaO} \cdot 2 \mathrm{SiO}_{2}$ 及 $2 \mathrm{CaO} ・ \mathrm{SiO}_{2}$ の漸减する認め, 次で他配合 物に就て此定量法を適用し 3 種石灰監の割合は配合比,加熱溫度, 時留等飞 
低りて變化するを確めたり。第5 報（同930）には $3: 2$ 配合物にて研究 し,水熱物中には $3 \mathrm{CaO} \cdot 2 \mathrm{SiO}_{2}$ が渐賭する事並に乾式加熱物中には $3 \mathrm{CaO}$. $2 \mathrm{SiO}_{2}$ の生成量少き事を報告せり。第 6 報(同 1087 )には $2: 1$ 配合物に 關する研究結果を揭げをり。

石灰と磁土ヌはアルミナとの水熱化合 永井彰一郎氏は水熱法に依る石 灰と磁土又はアルミナとの化合に關する研究第 1 報(本誌 35,537)に於て 粘土及 $\mathrm{Al}_{2}(\mathrm{OH})_{6}$ 加熱物の炭酸曹達液及稀隓酸に對与る溶解性を述へ，且 配合物 $\mathrm{CaO}+\mathrm{Al}_{2}(\mathrm{OH})_{6}$ は常壓水熱式加熱と乾式加熱との間に差異なをて とを報告せり。符 2 報(同，696）飞は石灰生粘土混合物の化合は乾式加熱 と常壓水熱式加熱との間に著しき差異なしとし, 終りに石灰と粘土又はア ルミナとの配合物の加埾水熱式化合几關する豫供實驗の結果を揭げたり。 第 3 報（同，979）には粘土石灰配合物の加㓡水熱式化合研究の結果を報告 し，粘土を豫め $600 \sim 800^{\circ} \mathrm{C}$ 亿熱すれ代化合率大なりと結論せり。

アルミ酸石灰の水熱合成 永井彰一郎氏はアルミ酸石灰監の水熱式合成 几關与る研究第 1 報(本誌 35,1240$)$ 飞於て $\mathrm{CaO}$ と $\mathrm{Al}_{2}(\mathrm{OH})_{6}$ 又は烺燒 $\mathrm{Al}_{2} \mathrm{O}_{3}$ との配合物を加壓水熱せる結果を揭げ, $\mathrm{CaO}$ 多ければ $3 \mathrm{CaO} \cdot \mathrm{Al}_{2} \mathrm{O}_{3}$ ・ $6 \mathrm{H}_{2} \mathrm{O}$ を生じ， $\mathrm{CaO}$ 少ければ低壓の時 $2 \mathrm{CaO} ・ \mathrm{Al}_{2} \mathrm{O}_{3} \cdot 7 \mathrm{H}_{2} \mathrm{O}$ 又住 $2 \mathrm{CaO}$ ・ $\mathrm{Al}_{2} \mathrm{O}_{3} \cdot 6 \mathrm{H}_{2} \mathrm{O}$ を生じ高埾の時 $2 \mathrm{CaO} ・ \mathrm{Al}_{2} \mathrm{O}_{3} ・ 3 \mathrm{H}_{2} \mathrm{O}$ を生ず結諭せり。

規格 日本ポルトランドセメント業技術會は日本ポルトランドセメント 规格解說 (準和 7,4$)$ 及早期高强度ポルトランドセメント規格案に關する回 答綜合表(ポルトランドセメント技報 21，(1))を發行したり。同會標準砂 委員(同 21, (3)) 相馬標準砂の供給狀態, 原砂山の砂粒分布狀態, 製造 工程及品質に就て調查研究の結果を發表したり。

軟練モルタル 濱田稔氏(ポルトランドセメント技報 20, 106)は規格の セメント强度とコンクリート强度との關係を諭じ, 小型軟練モルタルに低 
る新セメント强度試驗法を提案し其賽驗絬果を報告せり。服部武彥, 藤澤 國太郎兩氏(臺督研工報 89) は普通セメント，早高セメント及高爐セメン

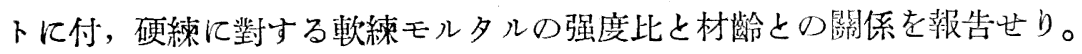
永井彰一郎氏( 空協 40,646; は獨逸, 瑞西に於ける軟練モルタルに依る試 驗法改正の機運に就て記述せり。

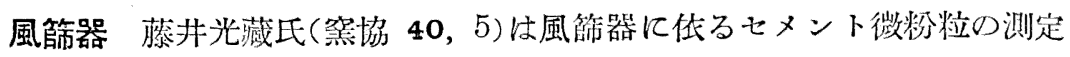
の筫際(其2)に於てゴネル風篲器と其成績とを述べ風析に依るセメント微 粉粒の必要なる测定䇭圍は $0 〜 60 \mu$ 附近以內をるを以て之には Goldstein 式を用ふべき事並にグットマン徑が便利をる事を結論せり。宮澤清氏(本 誌 35，1382)は新設計に依る風篩器の構造を述べ試料 $50 \mathrm{~g}$, 限界徑 $16 \mu$, 風篩洔間 30 分の實驗條件を舉げ本邦の普通セメントは $16 \mu$ 以下の粒子 40〜43\%，高級セメントは 46〜58\% なりと結墖せり。

物理性 內田桼郎氏(仙高工紀 10，(2) 606)はポルトランドセメントの 剛性率各栕セメントの强度と水量粉末程度等との關係, 硬化せるセメント に對する石油の滲透度，セメントと金屬との粘着度等に就て研究せり。

强度、服部武彥, 藤澤國太郎网氏はポルトランドセメントの强度に關す る研究其 5 (臺督研工報 68) に於て臺北附近にて用しらるる骨材を配した るコンクリートの耐壓力在研究し, 其 6(同 82) には本邦セメントの抗張 力並江耐壓力を檢し, 其 7 (同 85) には軟練モルタルに依る工事用砂の比 較試驗結果を示せり。

增强及防水性 吉岡藤作, 饭島容男兩氏はセメントの增强に就て研究を 續け第 2 報(本誌 35, 1214) 亿不灰石, 石灰土等化學的に何等交涉なき物 質の微粉をポルトランドセメントに混和したるモルタルの小型耐壓力は 1 ケ年に瓦り珪藻土, 火山灰, 珪酸白土等の增强成續に劣らずと結論し, 第 3 報(同 1403)に於ては水加膨脹性少き物質を容積にて 20\%だけセメントに 
涯加し小型强度を檢したるに優秀をる成績を得をり，且添加物質は $15 \mu$ 以下の微粉多き時强度大なりと報告せり。狞野春一氏(建築 1183) は石炭 質頁岩カォリン及び蛙目を混和したるモルタルの防水性及び强度に就て研 究世り。

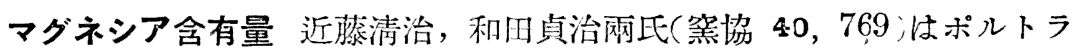
ンドセメント中の $\mathrm{MgO}$ 注石灰の化合を妨げボ水硬性の特に低からざるセ メントに於ては $\mathrm{MgO} 8 \%$ 老有するもつも膨脹性艘裂なく强度極为て高 く之㕝高厴蒸氣中にて長時間熱するる膨脹著しから少して强度著しく增進 す從て $\mathrm{MgO}$ は $8 \%$ 迄は差支なしと結論せり。

アルミナセメントの水和 小柳勝藏氏(窯協 40,489)はアルミナセメン 卜の水和作用儿就て研究し, 此水和仗先づ珪酸石灰の加水分解儿依る微量 ( $\mathrm{Ca}(\mathrm{OH})_{2}$ が $\mathrm{CaO} \cdot \mathrm{Al}_{2} \mathrm{O}_{3}+\mathrm{Ca}(\mathrm{OH})_{2}+6.5 \mathrm{H}_{2} \mathrm{O}=2 \mathrm{CaO} \cdot \mathrm{Al}_{2} \mathrm{O}_{3} \cdot 7.5 \mathrm{H}_{2} \mathrm{O} \oslash$ 反應老起 $\mathrm{L}$, 次に $2\left(\mathrm{CaO} \cdot \mathrm{Al}_{2} \mathrm{O}_{3}\right)+10.5 \mathrm{H}_{2} \mathrm{O}=2 \mathrm{CaO} \cdot \mathrm{Al}_{2} \mathrm{O}_{3} \cdot 7.5 \mathrm{H}_{2} \mathrm{O}+\mathrm{Al}_{2} \mathrm{O}_{3}$ ・ $3 \mathrm{H}_{2} \mathrm{O}$ の主反應が起り, 向 $2 \mathrm{CaO} \cdot \mathrm{Al}_{2} \mathrm{O}_{3} \cdot 7.5 \mathrm{H}_{2} \mathrm{O}$ の一少部は極て僅かに水 に溶けて $3 \mathrm{CaO} \cdot \mathrm{Al}_{2} \mathrm{O}_{3}$ 更に $3 \mathrm{Ca}(\mathrm{OH})_{2}+\mathrm{Al}_{2} \mathrm{O}_{3} \cdot 3 \mathrm{H}_{2} \mathrm{O}$ 亿變ると結諭せり。

ダストの利用 服部武彥, 林潜生兩氏(臺督研工報 80) はセメントダス トの利用に關する研究第 1 報に於てダストの化學組成, ダスト中の加里監 並に加里包收の豫備賽驗の結果を報告せり。

耐酸セメント 山村義次氏(化工资 5，(2）46；(3) 41)以耐酸セメント 飞關する試驗結果を報告せり。

光彈性セメントモルタル梁型試驗片模型の光彈性的研究(第 1 報)辻二 郎, 西四正孝兩氏(ポルトランドセメント技報 20, 120)。

コンクリート 鐵筋コンクリート杜耐涯强度實驗に關する一研究 結城 朝恭氏(仙高工紀 10,638), 京阪神に於ける現場コンクリート强度調查 近藤泰夫氏(ポルトランドセメント技報 20,201), コンクリート現場試驗 
報告 權藤利光氏(同 206), コンクリート强度と砂入セメント試驗强度と の關係 谷口德政氏同 215)，コンクリートの抗崕强度とセメントペース トの抗壓强度との關係 吉田彌七氏(同 238), コンクリート及モルタルの 應壓强度の間の關係 池部宗畺氏(同 253), 其他省略。

プラスター，山根茂氏(Sc. P. 18，101) は無機化合物の添加が石霄セメ ントの硬化速度に及湾す影響に就て研究し $\mathrm{CaSO}_{4} \cdot 2 \mathrm{H}_{22} \mathrm{O}$ の溶解度を大な らしさる監は硬化を促進すと云ふ Rohlandの說, 若くは Weimarn の沈澱

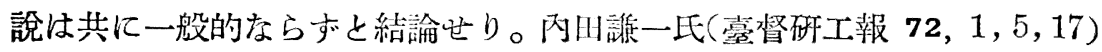
は臺雗産明攀石よりなるプラスターの應用試驗を行ひ明樊石に石灰石を混 和せるプラスターの特質保溫材としての長所吸濕劑としての性質を述べた り。同氏(同 27)は明攀石と消石灰とより成るプラスター凝絬物の化學組 成に就て研究せる結果を報告せり。

火山灰 中根俊雄, 山岡三秋兩氏(北工試 35,1 ) 小小標火山灰の人造石 及嬏としての應用を示せり。永井彰一郎氏(葖協 40,366)は獨逸の火山灰 ポルトランドセメントに就て記述せり。

銅鑛㵏 路面及床面鋪裝材料として銅鍍滓利用の研究, 船越重男氏（日 鑛 47, 1047)。

マグネシアセメント 福永範一,牛見五郎网氏(專研報 40,1 )はマグネシ アセメントに就て研究し $800^{\circ} \mathrm{C}$ に煆燒せる $\mathrm{MgO}$ が最も適當なる事 $\mathrm{MgCl}_{2}$ 液の濃度は $24^{\circ}$ Bé が最も優良なる事を述べたり。

\section{1. 石油及アスファルト}

石油成分 幸林良作氏(本誌 35, 342-349) は第 1 報(本誌 34, 792)に 引續きて西山油田に於ける數個の油井より收得せる原油の沸點 $200^{\circ} \mathrm{C}$ 迄 の釜残油を減埾下に $230^{\circ} \mathrm{C}$ 迄分溜して其の性狀及組成を試驗せり。其結 
果,減壓分溜油の主成分はナフテン系岑化水素 $\mathrm{C}_{14} \mathrm{H}_{28}, \mathrm{C}_{\mathrm{i5}} \mathrm{H}_{30}, \mathrm{C}_{17} \mathrm{H}_{34}$ 等に して他にパラフィン類及ポリナフテン類を含有す。猶,不飽和炭化水素及芳 香族炭化水素等の含有量は常壓分溜油よりも稍々大なることを報告せり。 更に氏は第 3 報に於て(本誌 35，1038-1043) 新津油田に於ける 4 楮の原油 より常壓分溜に依て $200 \mathrm{C}$ 迄に收得せる各溜分の性彇及組成を研究の結 果, 各溜分何れもパラフィン族炭化水素と共にナフテン族炭化水素の相當 量より成るてとを確めなり。

製油 加藤常太郎氏(九工荤 7，110-126)はタラカン重油を 10 atm 以下 の加壓下に分解蒸溜せる際, 厴力, 溫度及時間等が分解溜出油及釜残油に對 し如何なる影響を及忹す可きかに就て試驗せり。其結果を綜合するにタラ カン重油の $210 \sim 300^{\circ} \mathrm{C}$ 溜分にては壓力 $1 \mathrm{~atm}$ 增大寸る每に平均分解溫 度約 7 $10^{\circ} \mathrm{C}$ 上萃す。又, 分解溜出油の揮發油分收率は壓力及分解溫度 の上景につれて著しく增大す。殊に厴力の增加は上記の如く分解溫度を上 昇する結果收率に影響するとてろ大なりと報告せり。溝下征, 上野正治网 氏(南滿試 16，53-65) は撚順產頁岩原油に 6\%の酸性白土を擔體とせる 還元ニッケルを觸媒として高溫高壓水素添加の絬果, 飽和度高き揮發油, 燈 油, 重油等, 各種優良なる油分を收得せり。唒鐲媒を使用せざる場合に於 ては粘稠なる樹脂質を多量に生成することを報告せり。前田稔, 上野正治 兩氏(南滿試 16, 67-79) 亦, 撚順兴頁岩原油を酸性白土を混和せる還元 ニッケル 5\%, 水素初壓 $80 \mathrm{~atm}$, 水素添加溫度 $375^{\circ} \mathrm{C}$ にて 20 時間水素添 加の結果油分の不䳌和度著しく低下し極めて良質なる燈油分 $11 \%$ を收得 することを得たり。此際石蠟分は分解すること無く反つて增收を來し而\& 其の發汗作粱容易なるととを認めたり。猶水素添加溫度を $435^{\circ} \mathrm{C}$ に上景 し水素添加時間を 3 時間に短縮する時は飽和度高き優良揮發油分 $13.8 \%$ (容量\%), 燈油分 $21.7 \%$ を放得し得ることを報告せり。田中芳雄, 小林 
良之助, 西野榮一氏等(航空研彙 95，559-569)は粗製モビール油に0.5\%0 酸化ニッケル及 $3.3 \%$ の酸性白土を觸媒として混和し高溫高壓水素添加の 結果, 水素添加油は資油に比してコンラドソン氏炭素量及不飽和度減少し 色度減褪して其の安定度を塤大し, 粘度は稍々減少する 8 溫度變化に依る 粘度變化減少しパラフィン量少量增大する等砶秀なるモビール油に變化す るととを證明せり。

天然瓦斯 田口清行氏（石油 196-205，294-302) は錦水產天然瓦斯及之 をサウス・ウェスタン・エンヂニアリング會社の $400 \mathrm{M}$ 型の揮發油吸收裝置 几依て吸收せる天然揮發油の性状, 組成, 其他を米國紊天然瓦斯及天然揮 發油と比較考察の結果, 米國に於ける天然推發油の平均探收率は天然瓦斯 1,000 立方吹に付 1.2 ガロンなるも錦水にては約 0.5 ガロンに過ぎず,而も 其の組成輕質なるを以て油井の深度增大と共に天然揮發油蕾産す可きとと を推定せり。同氏(石油 49-59)は更に錦水產天然瓦斯よりカーボン・ブラッ ク製造の現狀及製品の品位等が米國產カーボン・ブラックに比較して優劣な きととを論じ其のゴム用及インキ用カーボンとして利用し得るととを說述 せり。飯高信男氏(石油 283-293)は本邦に於ける天然瓦斯の利朋法として液 化瓦斯（液體プロパン及ブタン）製造の急務なるととを論述し，松䇾傅太 郎氏(石油 361-369，447-454) 恃錦水に於ける天然瓦斯よりカーボン・ブラッ ク製造の沿革及現沉を詳述せり。また白土萬次郎氏(石油 599-609)は國產 コーモリ印カーボン・ブラックを印刷インキ材料として品質試驗の結果, 米 國鑛山局の明細書に合格し，之をトライアングル印と比較する時は著色力 少しく劣り吸油量多き色相其他に於て優るてと走證明せ门。

石油試驗 水田政吉氏(本誌 35，78-81) は多數の空氣埾縮機の厴縮比が 6 以下なることを計出し, 此の壓縮比飞對應する終溫より $50^{\circ} \mathrm{C}$ 高をとと を標準として市販壓縮機油の最低引火點を $180 \mathrm{C}$ と規皆す可きてとを提諭 
せり。更に同氏本誌 35，81-84)は同氏の考案にか子る A.P. D.法 (アニ リン, ポイント降下法, 本誌 34, 1268-1275) 亿對するチオフェンの影響 を試驗の結果, 該影響はベンジールの約 $60 \%$ てして通常の直溜揮發油の 定量に於ては其の補正を要せざることを證明せり。更に同氏は直溜揮發油 上り $98 \%$ 硫酸にて芳香族炭化水素を除去せる後のアニリン・ポイントを $\mathrm{T}$ とする時は直溜揮發油中のナフテン族炭化水素量 $\mathrm{N}(\%)$ は $\mathrm{N}=\{(72-$ T) $172-(40-0.5)\}(1,000-\mathrm{Ar})$.にしてパラフィン族炭化水素量 $p(\%) は$ $p=100-(\mathrm{N}+\mathrm{Ar})$ なるととを推定せり。此式中 Ar は芳香族炭化水素量 （\%)なり。同氏は更に(本誌 35，200-207)本邦崖の揮發油溜分を有する代 表的原油 68 種類を分溜して收得せる揮發油溜分に就て其の比重の實測値 と計算值とを比較せり。但し計算值は揮發油中の䓅香族，ナフテン族及パ ラフィン族炭化水素の各平均比重 $0.8748,0.7810$ 及 0.7240 に A.P.D. 法 飞依て定量せる各岑化水素の含有量(重量\%)を乘じて得をるものなり。其 絬果は少數の高沸點溜分を除をでは計算值と實測做と一致し, 氏の考案せ る定量法の實用的なるととを證明世り。同氏は又(本誌 35，139-142)エン グラー蒸溜試驗成績がェングラー・フラスコの保㴘法に左右せらる」てと を觀察し，加熱裝置の風除けの上部に石綿板の蓋をする場合と然らざる場 合及フラスコの頸管全部を石綿紐にて卷く場合と然らざる場合等比较試驗 の結果, 單にフラスコの頸管全部を石綿紐にて替きたる埸合が揮發油, 燈 油, 輕油を通じて最良の成績を與ふるととを確認せり。管義夫氏(理研報

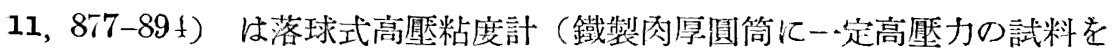
壓大し鋼球が其內の 2 䟕を通過する時刻を電氣的方法に依て觀測して此の 時刻より高壓下に於ける粘度を計出する裝置）飞低て $18^{\circ} \mathrm{C}$ 亿於て 2,000 $\mathrm{kg} / \mathrm{cm}^{2}$ 迄の壓力下に種々なる鑛油,植物油等に就て粘度测定の結果興味深 を現象を發見せり。例一ば $18^{\circ} \mathrm{C}$ に於て埾力の上昇につれて粘土の上昇 
するは元よりなりと踓も“ ABC Mobiline oil C” は $1,100 \mathrm{~kg} / \mathrm{cm}^{2}$ に於 て液狀パラフィンは $1,300 \mathrm{~kg} / \mathrm{cm}^{2}$ 飞於て部分的固化し㷠飞鑛油重油は比较 的低壓下 (約 $300 \mathrm{~kg} / \mathrm{cm}^{2}$ 以下) に於て固化するに反して苳矿子油は 2,000 $\mathrm{kg} / \mathrm{cm}^{2}$ 几至るも部分的固化現象を現はさがることを確認せり。

鑛油の酸化 山田貞吉氏(本誌 35，1-15，574-577，1165-1168)は(1)粗 製絕緗鑛油を約 $140^{\circ} \mathrm{C}$ に加熱する際銅，県鑄，銀，鉛等は其のスラッヂ 生成作用を促進するもマグネシウム, 錫, 亞鉛, アルミニウム等は防止し 精製絕縁鑛油飞對しては銅, 亞鉛, 鉛, マグネシウム等が防止作用あるて とを認め，(2) $0.1 \%$ ๑ナフテン錫を混和する時は絕縁鑛油は其の絕䋓耐 力を低下するとと無く $120^{\circ} \mathrm{C}$ 亿 50 時間加熱するる精製油着色せす精 製油は生酸せざることを認め, (3) 鑛油を眞空中, 咥素中, 炭酸瓦斯中に 於て $140^{\circ} \mathrm{C}$ に 100 時間加熱せるも色調變化無くメスラッヂ生成せず。故 に酸素は鑛油のスラッヂ生成に必須要素なるととを認め，(4)精製鈸油及粗 製鑛油の酸素吸收速度に對する各種の有機酸即ちステアリン酸, 油酸, ナ フテン酸, 安息香酸, 蓚酸及石油酸等の影響を研究の結果, 精製鑛油に 對しては上記酸類何れる促進作用あるも粗製鑛油に對しては單に油酸及ナ フテン酸の促進作用あるととを認めたり。又(5)鑛油を酸化して收得せる 酸は精製鑛油の酸化作用を阻止する为粗製鐄油の酸化は促進するてとを證 明し，(6)アルコール 類は一般て精製鑛油の酸素吸收作用を多少促進する も誘導期間は消隇せず，粗製鑛油に對しては生酸作用を防止するてとを認 め，(7)ヂ・オキシ・アセトン及グリセリン・アルデヒドは精製鈸油の酸素吸 收作用を促進し就中, ヂ・オキシ・アセトンは其誘導期間を消滅するととを 認めたり。

性狀 並河孝, 吉弘太作つ兩氏は（海燃研 64, 1241-1247; 本誌 35, 719-722)海軍規格飞合格せる 1 號外部金廣油, 2 號外部鐄油(以上減摩油), 
3 號外部鑛油 (眮滑油)を試料として元素分析, パラフィン分, 炭素分, 酸價, 硫酸吸收量, 比重, 膨脹係數, 粘度, 凝固點, 引火點, 抗乳化度, 安定度 及溫度に對する比重, 比熱, 粘度の變化等を測定の結果, 比重, 粘度, 比熱 几關する實驗式を與人, 各油の粘度の溫度係數は 日/C に逆比例するてと及 市販石油, 重油に比して各油間の成分均一なるてと等を明白にせり。更に 氏等 (海然研 63, 1223-1239; 本誌 35, 722-728)はオ八重油, タラカン重 油, 加州重油, 加州ケットルマン, ヒルス重油, 撚順産頁岩油の 5 種を試 料として比重, 膨脹係數, 粘度, 凝固點, 比熱, 引火點, 自然發火溫度, 發熱 量, 水分, 灰分, 炭素量, 水素, 硫黄分, 炭素分, アスファルト分, 硫酸吸收 量, 分溜試驗, 溫度飞對する比重, 膨脹係數, 粘度, 比熱等の變化老測定 の絬果 (1)比重, 粘度, 比熱汇關する實驗式を與へ，(2)以上 5 種の重油 ともに比重及比熱が溫度と直線的に變化するとと，(3) 比熱及膨脹係數 間の關係, (4)パラフィンの粘度變化及自然發火溫度に及居す影響，(5)發熱 量が水素合有量に比例するてと等を明白ならしめたり。水田政吉氏（本誌 35，418-428) 恎灣出磺坑, 越後西山, 東山, 大面原, 新津, 秋田及北海 道各油田原油の 揮發油溜分の一般性質及炭化水素組成を各油田別江總括 し, 各特徵を歸納し且之等揮發油溜分の特徵を根據として日本産各種油田 原油を此較評論せり。次で著者は炭化水素組成の相違て依て日本産揮發油 溜分を芳香族性揮發油溜分, パラフィン族性揮發油溜分, パラフィン・ナフ テン族性揮發油溜分及ナフテン族性揮發油溜分の 4 種に分類し，且日本產 原油の地理的分布と揮發油溜分の炎化水素組成間に存在する關係を述べた 口。毁古芳香族炭化水素の含有量は北部油田飞進むに從ひて增加し, 反之, ナフテン族炭化水素は北部油田に多く南部油田に於てそしきを觀る。又臺

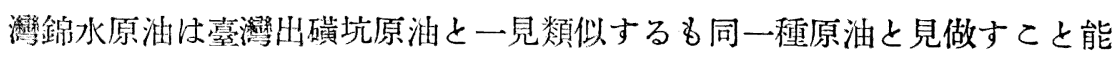
はホ。。然れぞも同原油揮發油溜分は日本產原油中, 出礓坑原油の揮發油溜 
分に亞で䇰香族炭化水素に富み，且ナフテン族炭化水素にきしきととを證 明せり（猶,石油時報 29, 187，271，437 筞參照）。

アスファアルト 今年度に於けるアスファルトに閔する興味ある研笔殆ど 無し。

\section{2. 乾溜, 瓦斯 及燃料}

石炭の成分性質 新村唯治氏(燃研報 13, 1-78)はレッシング乾溜裝畳を 用ひ本邦岸及支那炭 88 程につき乾溜試驗を行ひ，石炭の粘結性，膨脹性等 の测定裝置としての該裝置を吟味し坩堝法と比愺し更に加熱率と膨脹性， 粘結性, 瓦斯及夕ールの生成量繁との關係を求め, 之等の絬果上り弱粘結

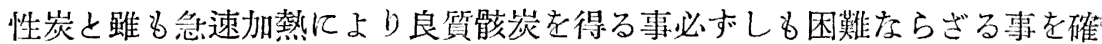

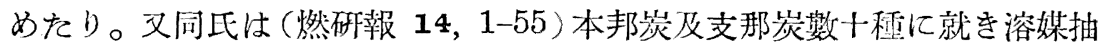
出法によりて $\alpha, \beta, \gamma$ 各成分を分ち, 之等と石岑の膨脹性, 骸岑化性との 䦰係に就き研究し，强粘結炭と弱粘結炭とは其の $\gamma$ 化合物量 $10 \%$ 前後を 境として區別せらる」も石炭の骸炭化性は單に $\gamma$ 化合物の量のみを以ては 說明する事能はず，之と共に $\propto$ 化合物の酸素量が密接なる關係ある事を認 めたり。橫田俊雄，硪谷延治兩氏 (海燃硎 62，1011-1022) は撫順大山炭を 115-800`C の各溫度に加熱したるもの〉比熱を测定したる絬果，石炭の比 熱は其揮發分の減少と共に低下し其值は組成元素たる $\mathrm{C} ， \mathrm{H}, \mathrm{O}$ の原子熱 より計算せる値と一致する事を確め, 此事實より $115^{\circ} \mathrm{C}$ 以上に於て石炎 より放出せらる〉水分は石炭の吸着水分にあらずして化合水分なるべき事 を推論せり。多和田寬氏(燃協 11，942-52) 岋美唄粉炭几つき屋內及屋外 に於て眝藏する場合に於ける變化郎ち水分, 雪塊混入量, 風化度等につを 研究し更に之を火床上に撒布する場命之に對する水分量の影響及之が然燒

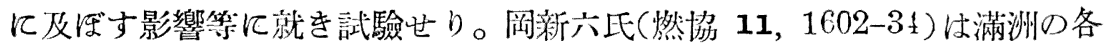


種無煙炭及有煙炭につき, 其外觀, 顯微鏡組成等上り之の特性を研究し冈 地炭と比較し其根源, 年代等につき論述せり。

木炭, 骹炭の性質 大息義清, 福田義民兩氏(本誌 35, 560-74) は微粉 狀各種炭素試料に一定量の空氣を揆りつ」加熱し其の着火溫度に至る迄の 行程に於ける變化老研究し, 一定の加熱率及空氣量に於ては燃燒減量と溫 度及着火溫度との間に直線的關係する事を認め, 又着火溫度は炭素の晶質 度に關係与るも燃燒速度は炭素の種類に, 揮發分及空氣流率は着火溫度に

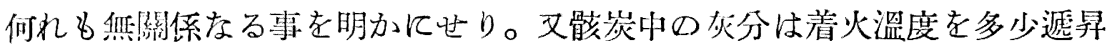

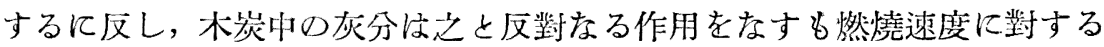
灰分の作用泼極めて微弱なる事を認めたり。三浦伊八郎氏(林學 14, 272， 283) 牥市販の煉炭及木炭數種につき總硫黄量, 燃燒性硫黃量, 灰分, 發熱

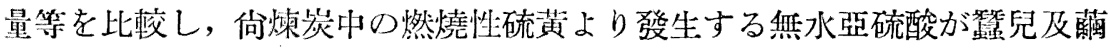
綵つ性質に及将す影響につき試驗せり。

水素添加 阿部艮之助氏（本誌 35, 29-42, 1165-8） は㨘順炭の水素添 加に關する細媒に就き引續き研究を行ひ，四三酸化鐵及第一酸化鐵を用ひ 之等が水素添加に及代す影響郎占 $P / T$ 曲線の變化並に油化率等に就き研 究し, 更に使用觸媒の $\mathrm{X}$ 線分析によりて其の還元度学求め, 之と油化と

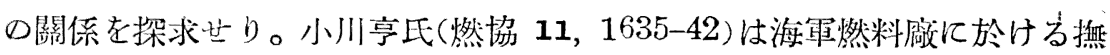
順岑油化法の研究經過及成績の概要につき報告する處あり。

乾溜及燃燒 高原謶一郎氏(燃協 11, 306-12) は構造簡單操作容易にして 且弱粘結岑より良質䯏炭を得らるべき新式水平焻道式䯚炭嘘を考案し，其 の構造操作法に關し報告し,岡大四郎氏(燃協 11，66-72)は石炭の完全燃燒 方法を推理研究し麼芥燒却溫水罐を創製し之の構造機能に就き報告せり。

測定裝置 下村明氏(燃協 11，184-9)は加熱に上る石炭の收縮及膨脹を 控大して之を直に曲線として自記し得べき新测定裝置を考案し, 内田正次 
郎氏(燃研報 12,1-72) は石岑熱量計の製作につき研究し, 比較的麻價に して测定法簡單迅速, 然も普通のベルトロー式と同等の正確度を示すべき 燃研式斷熱を量計を創製せり。

其他 山本鿆二郎氏(早應化 17, 15-9, 1165-8) は沼鐵鑛によるベンシ 一ルの吸着につき研究し, 不純物少く化合水多き沼鐵鑛を適當の溫度に於 て燒鏣せるものは吸着劑として極めて適當なる事を確めたり。

\section{3. 染料, 染色及紡織化學}

合成染料 古田迪氏(內印 22，143-149) はレーキ用赤色アジ染料リソ ール・レッド(トビアス酸 $\rightarrow \beta$ ナフトール)の製造に就て璝驗し， $\beta$ ナフトー ルより2-ナフトールー1ースルフォン酸の階梯を經てトビアス酸を製する條 件，並にレーキ製造の際沈洪劑が色相に及す影響其他に關して報告せり。

尾形輝太郎氏 (P. I. A. 8, 119-122) はメチル・キノリン類のョードェチ ラートに醋酸アルカリ及無水醋酸の存在に於てヂフェニルフォルムアミ ヂン $\mathrm{C}_{6} \mathrm{H}_{5} \cdot \mathrm{N}: \mathrm{CH} \cdot \mathrm{NH} ・ \mathrm{C}_{6} \mathrm{H}_{5}$ を作用せしめてェテニル化合物 ( $\mathrm{I}$ 型) 製 し，之をメチル.キノリン類と $100^{\circ} \mathrm{C}$ に於て縮合せしめて種くなる感光性 カーボシアニン類を合成せり。而して例へばキナルヂンのェテニル化合物 (I)とレビデン・ヨードェチラート(II) とを縮合せしめて生ずるカーボシア ニン(III)よ, レピヂンのエテニル化合物及キナルヂン.ヨードェチラート より生成するカーボシアニンとの同一をることを認め, 之を以てカーボシ アニン類に於ける互變異性の一證明坊りとせり。

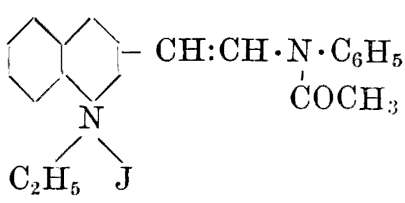

(I)

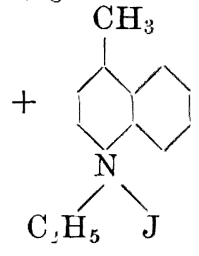

(II) 


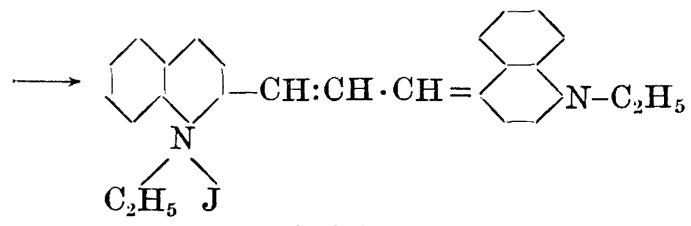

(III)

牧銳夫氏(本誌 35，1437-1440) は純粹なるベンズアンスロン（補正融點 $17 \cdot 27^{\circ} \mathrm{C}$ ) を製し, 之を加里熔融して建染染料ヴ ィオランスロン郎ちヂべ ンズアンスロンを合成する反應に就て研究し, 從來未知なる數種の副生物 老見出し反應生成物を先づ(a)黃褐色のアルカリ可溶成分, (b)褐黃色の水 醋酸可溶成分，(e)ハイドロサルファイトに難溶度る紫灰色色素ヴィオラン スロン B 及 $(d)$ 青紫色のヴィオランスロン A, 郎ヂベンズアンスロンの 4 種に大別せり。而して石岑酸其他フェノール類の添加はインダンスレンの 場合と同樣, 此熔融に於ても格段なる縮合促進作用を示し, 適當の條件に 於ては無噣媒熔融に比し約 2 倍の收率を以てヴィオランスロンAの得ら るってとを見出したり。次で牧氏(本誌 35，1441-1444) は上記各種反應生 成物の性狀に就て種々實驗を試み, 先づ (a)アルカリ可溶成分はパーキン ○ 2-オキシ・ベンズアンスロンに全く一致するととを明かにし, 且其未知 融點 298〜 $299^{\circ} \mathrm{C}$ (補正) を測定し, (b) 水醋酸可溶成分たる融點 $272^{\circ} \mathrm{C}$ （補正）の黃色針壯結晶はベンズアンスロン 2 分子が縮合せる中間體 $2.2^{\prime}-$ ヂベンズアンスロニル型物質なるを認幽，(c)柴灰色建染染料ヴィオランス ロン B (濃硫酸溶液の最大吸收點 $6360 \AA$ は挀知のジベンズアンスロン或 はイソヂベンズアンスロンの單をる還元生成物に非ずして著しく骨骼を異 にせる縮合體をることを推定し，(d)ヴィオランスロン A に就ても之を極 めて純粹なる形となし(濃硫酸溶液の最大吸收點 $5700 \AA$ ) 從來未知なる性 質, 就中此物がインダンスレンと同樣 $250^{\circ} \mathrm{C}$ 附近の高溫アルカリ熔融に より著しく二次的分解を惹起する事實等を見出したり。 
青山新次郎, 森田一貫兩氏(衛生試報 40, 135-144) は 1・8-ヂオキシ・ア ンスラキノンの製造に就て報告せり。

天然色素及タンニン類 黑田チカ，松隈ときよ兩氏（理研㪕 11, 389-

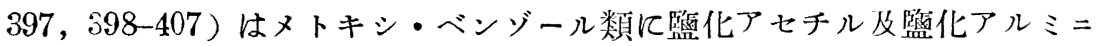
ウムを作用せしめてメトキシ・アセトフェノン誘導曧を製し，此等とメトキ シ・ベンズアルデヒド誘導體とを縮合せしめて秏々なるカルコン誘導體を

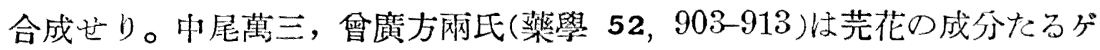
ンクっニン(融點 $286^{\circ} \mathrm{C}$ )の構造に就て研究し之を $5 \cdot 4^{\prime}$-ヂオキシ -7 ーメトキ シ・フラヴォンなりとし，服部猙夫氏（Phytochim. 6, 131-154）はフラヴォ ン誘䆃體の吸收スペクトルを测定し，フラヴォンの第一吸收帶(波數 3500) 並に第二吸收帶(波數 4500) に對するヒドロキシル基の位置及數の及す影 響に就て報告せり。ニーレンシュタイン氏 (M. Nierenstein, Phytochim. 6, 174-175) はオキシ・クリシンを 5・7・8-トリオキシ・フラヴォンなりとし,此 物の融點岋 1912 年同氏の测定せる如く 304 305 C にして, 1931 年服部
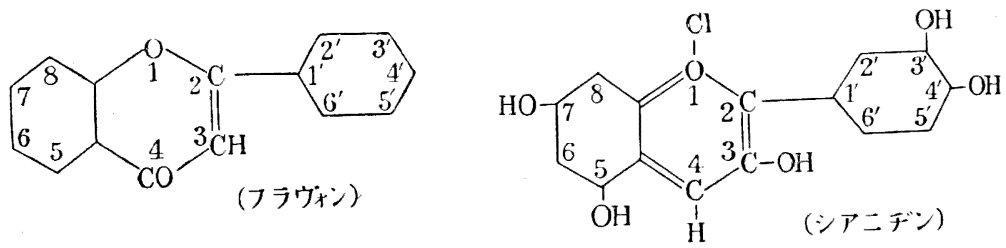

氏が發表せる $227 〜 228^{\circ} \mathrm{C}$ は正しからず, 恐らく結晶水に基くものならん と論じ, 且 1930 年服部氏の發表するノル・ウォーゴニンに疑ありとせり。服 部靜夫氏 (Phytochim. 6，177-178) は之を反駁してオキシ・クリシンと5・ 7・8ートリオキシ・フラヴォンとはトリア七タートの融點一致せるも必柇も 同一物と見做し難しと述べたり。中沖太七郎氏(萩學 52, 1085-1088,10891093) は多數の白色花に就きフラヴ $ン$ 配糖體の定性的武騟を行ひ，又白 躑躅の花扢に仿するものはケル七チンのグルコース及ラムノース配糖體な 
るととを報告せり。

近藤墨氏(藥學 52，353-357，358-361)は各種フラヴォン屬色素をメチル アルコール性監酸に溶解し $\mathrm{Na}$ アマアルガムて還元し， $20 \%$ 以上の收率 を以て對應するアントシアニヂンを得をり。叉メトキシル基を有するフラ ヴォン屬色素に就ても之を適用して好結果を見たり。山本亮, 大島康義网氏 （Sc. P. 19，134-141）は Hiviscus babdariffaL.の蓦より赤色色素を分離 して其構造を塆究し, 此物がシアニヂンの配䌅軆にして 3 の位置に於ける ヒドロキシル基がペントースと絬合せるものなりとせり。西川英次郎氏 （農 化 8，1007-1015)は絲状菌の1種なる Monascus purpureus Went の赤色色素モナスコルブリン $\mathrm{C}_{22} \mathrm{H}_{24} \mathrm{O}_{5}$ の性質に就て檢しカーラー rer）等の研笁結果と比較せり。

村上增雄氏(日化 53，162-180)はマンゴスチンの陆造に關する研究を續 行し,テトラヒドロ・マンゴスチンを酸化する際イソカプロン酸を好收量に て得るとと，又ヂメチル・マンゴスチンを氷醋酸中にて湽監酸と共沉永く 加熱する時オキソニウム監を生ずるてと等よりして，マンゴスチンの分子 冈に濃酸により加水分解せらる」六角環㭊のエーテル型むる㐫のとなし， 同氏が既に與へたる式を訂正して次式を提出せり。(IV 及 V)

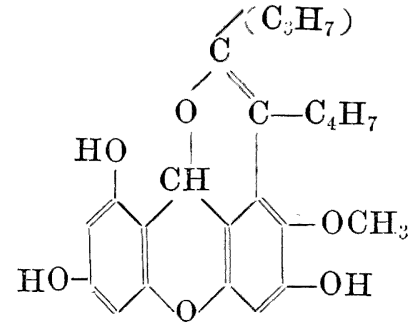

(IV)

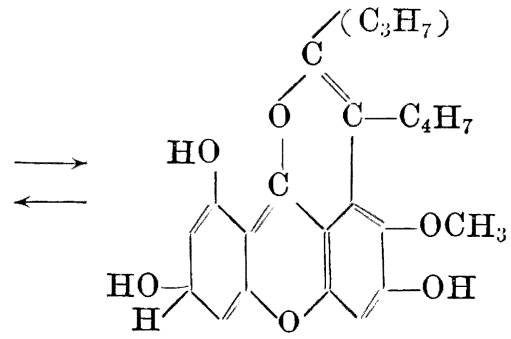

( V)

辻村みちよ氏 $S c . P .18,13-21)$ は綠茶の石油エーテル抽出液にメチル 
アルコールを添加して沈溉せしむる操作を反覆し，融點 $167 〜 168^{\circ} \mathrm{C}$ なる $\alpha$ 及 $\beta$ 種の結晶性カロチン混合物を分離し, 又石油エーテル母液上りヂ ヒドロ・エルゴステロルの 1 新種(融點 $167-168^{\circ} \mathrm{C}$ ) を絬晶として得たり。 小林久本, 山本研一, 阿部二郎氏等(本誌 35, 70-77)壮棕櫊油中にカ口チ ンの存在を確め, ベンジール溶液に就て酸性白土及非酸性白土の呈色を比 較したるが, 前者は青色を呈し且呈色の强弱は脫色力に比例すること, 又 後者は呈色遙に微弱なるてとを認めたり。

上田嘉助, 石名田喜久男兩氏(本誌 35，964-965)は矢車のタンニンを抽 出しアセチル,ベンゾイル,メチル等の誘導體を製して研究したる結果, 豫報を訂正して之をチガルス酸の1種なりと報告せり。

\section{染料の光化學 櫻井季雄氏(理研報 11, 681-710, 1044-1059) は多數の} キノリン系感光性色素に就き分光化學的並に寫䢐化學的研究を行ひ, 複素 環式監基の核几置換せられたる脂肪族基は最大吸收點並に感光極限を幾分 長波長側に移動せしむる力あるる，感光極大に對する影響は谌だ僅少なる を認めたり。櫻井氏は又此種色素に就き同氏の改良せる方法によりて色感 光を測定せり。櫻井氏は别に(理研報 11，711-728)ヂアミノ・ヂフェニルア ミンより生ホるテトラゾ化合物の監化亞鉛複監を陽畫印畫几應用して好結 果を得ることを見出し， $\beta$ ナフトール，H酸， SS 酸等のアルカリ液にて 處理する時青色を得るとと等を報告せり。

福島郁三, 堀尾正雄, 大森政敏氏等(本誌 35, 984-990)はアジ化合物の 光反應に於ける酸化亞鉛の增感作用に就て研究し, アジベンゾールの如を 基礎化合物は㫊ぞ定量的に光化學的還元を受けてヒドラジベンジールとな るに反し, 助色眯存する染料クリスタル・スカーレット， $p \cdot p^{\prime}$-オキシア ゾベンゾール・スルフォン酸監等にありては條件により酸化及還元の隻方が 行はるよてとを認めをり。 
染料の膠啠化學 田中隆吉氏(本誌 35, 349-361，1363-1368) はコンゴ ー・レッド水溶液に硝酸を加へてコンゴー酸を沈澱せしめ, 蒸溜水にて透折

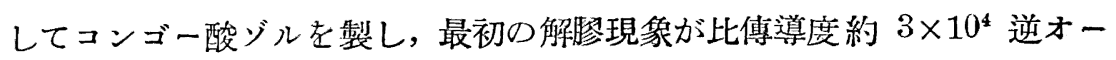
ムの點に於て起るてとを確知せり。而してコンゴー酸ジルに監化カリウム の如き中性監を少量添加すれば，青色沈澱を生ずると同時に上澄液の分散 度向上し, 中間濃度に於て上澄液は赤色を呈し, 中性鹽が更に高濃度とな ればゾルは悉く凝固することを認め, 又鹽化カルシウムの如き中性カルシ ウム鹽に於ても類似現象あることを報告せり。田中氏は更にコンゴー酸ゾ ルを白金血中にて加熱する時生ずる青色より赤色に向ふ色變化を各濃度に 就て觀察し, 初濃度小なる程赤變程度大なるととを確め, 且此現像をコ口 イド粒子分散度の賭大, 複分散系の形成, 加熱粒子が非加熱粒子ょりも活 性を有するてと等によりて說明せり。晌スルフォンシアニン $5 \mathrm{R} に$ 就ても 同樣の實驗走行ひたり。

染料の吸着 田中芳雄, 桑田勉, 古田迪氏等(本誌 35, 649-656)註各種 染料の酸性白土による吸着現象に就て研究し, 水溶液に於ける盬基性染料 の吸着は主として色素監基と白土の活性珪酸との造監によること, 酸性染 料の場合には主として梁料より色素酸を遊離せしむるに基くてと，直接染 料の中，例へばコンゴー・レッドの如きは紫色を呈して强固に吸着せらる」 とと，叉アリザリンの如き媒染染籼は白土のアルミナ類と結合して赤色を 呈する等の事實を認めをり。

染色 久保田桐造氏(本誌 35，577-583，583-586) は黑色硫化染色綿綵 を加熱する際繊維上に於ける硫黃, 遊離硫酸及全硫酸根の變化を測定し, 且染色綿絲抽出液の性質を吟味せり。而して此等染色綿綵の脆化防止後處 理としては遊離硫酸を中和する目的を以て, 苛性ソーダとして $0.2 \%$ に相 當するアルカリを存在せしむべきてとを提唱せり。宮岡宇一郎, 坼田隆士 
の网氏(色染 3，285-289) はベンベルグ絹絲に就き染料吸收率と染料溶液 濃度, 助劑濃度, 溫度, 染色時間等の關係を测定せり。立木勝藏, 見並清

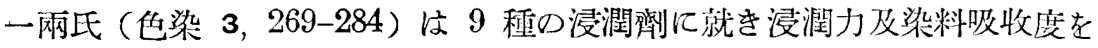
比較し, 此兩者が大體一致せるととを認めたり。河田善太郎氏（繊工 8 , 94-98) はヴィスコース綃絲製造工程中に於ける種从なっ條件と, 其染色に 於ける斑染との關係に就て報告せり。

近藤美雄氏（色染 3，290-293，343-352）は國愿及が外國染料の對比試 驗老續行し, 染料品位, 染色性, 堅䒠度等の見地上り國成クリソフェニン NS コンクを 7 種の外國品と, 國率ジャパノール・ブラウン M を 8 種の 外國品と, 又國宸ニッポン・スカーレット B を 3 種の外國品と比较せり。

媒染 菱山衡平, 關口春雄兩氏(本誌 35，361-365)はクロム明樊溶液を

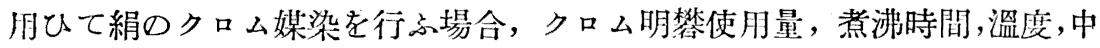
性鹽涯加等がクロム固着量に及す影響に就て實驗し, 又菱山氏(本誌 35 , 876-879，880-883）は此際クロム明禁溶液の監基度が $\mathrm{Cr}_{2} \mathrm{O}_{3}$ 及 $\mathrm{SO}_{3}$ の固 着量に著しき影響を有し，媒染浴の浱度如何に泃ら㑼及直線的關係の成 立するてとを明かにし，又ク口ム明樂を用ふる加熱式綟媒染に於ては液の

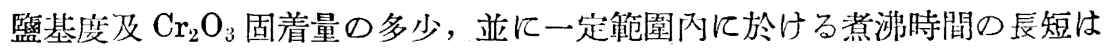
絹絲の强力伸度に殆ゼ影響を及さざれぎも，媒染したる後染色せずして放 置する時は時日の經過と共飞著しく纎維の强力伸度を低下することを認め たり。上村六郎氏(染織 52，460）は蘇芳染と灰との關係に就て報告せり。 郎ち蘇芳の赤色染色に於ては明禁又は灰汁を必要とし, 且灰の使用量大な る程色調は紫色に近つく事實に基き, 古代の蘇芳染を批制し, 延喜式其他 に於て過量の灰の使用せられしてとを指摘せり。

上田嘉助氏(本誌 $35,966-967 ， 968-970$ ) は $15 ， 25$ 及 $30^{\circ} \mathrm{C}$ に於て種 々なる湦度のタンニン溶液に就き脫脂綿によるタンニン吸收率を测定し， 
タンニンの涉度 $4 \%$ の時最高の吸收率を示すこと, 並に低溫なる程吸收良 好なるととを認めたり。佾タンニン定量はレーウェンタールの過マンガン 酸加里法に依れり。

松岡省吾氏（Bull. C.S.S.J.7，50-56）はアリザリンを飽和明攀水にて 薏沸し，トルオールより結晶せしめアルコールにて洗涤する方法によりて 精製し，未補正融點 $288.5 〜 289.5^{\circ} \mathrm{C}$ の純品となし，此つアリザリンをアル ミ酸ナトリウムの水溶液に添加する時生するる深橙色親水性コロイド物質の 州質に就て研究し，之をアリザリン 3 分子，アルミ酸ナトリウム 1 分子よ り生成せる $\left(\mathrm{C}_{6} \mathrm{H}_{4} \succ{ }_{\mathrm{CO}}{ }^{\mathrm{CO}}>\mathrm{C}_{6} \mathrm{H}_{2}{ }_{\mathrm{O}}^{\mathrm{O}}\right)_{3} \mathrm{AlNa}_{3}$ なりとし其配位式を推定せり。 絹及其精練 豊田今吉氏は後藤章氏 (本誌 35，85-88), 後藤泰一氏 (同) 88-96), 山本隆治氏(同 96-101) 等と共同にて絹精練に就て研笲し, 先づ

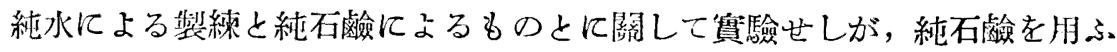
る時は純水の場合よりは色相及觸感に於て良好なれども，練減量大にして 且强度も相當低下するととを認めをり。佮替利策比(本誌 35，1010-1015) は絹の除膠後作用，印ち絹の石䀫精練後に於て繊維に吸着せるアルカリ， 脂肪酸及石铪が嶻維に及す影響に就き, 絹の光澤, 强度, 絹鳴, 染色性等 の見地より研究せり。

福島郁三，高松勇治郎网氏(本誌 35，20-‘9) は絹フィブロインに對する 銅アルカリ液の作用に就て研究せるが, 銅アムモニア液の場合にはフィブ ロインと銅との間に相互溶解現象のあるとと，又銅ェチレンヂアミン液に 於てはフィブロイン: $\mathrm{Cu}: \mathrm{En} \fallingdotseq 1: 2: 2$ なる結合當量の存在するととを報 告せり。

\section{4. 油脂, 䗵 及石 簽}

油脂類の性狀及成分 加福均三, 池田鐵作, 畑忠太氏等(日化 53,388, 
$395 ， 436,1115)$ は臺灣㣺植物油の研究として,アカギ, 樟, テリハボク, ククイ, 支那油桐, モモタマナ, シンラン, 月桃, セイロンオリーブ, 廣 葉杉, 銀合歡, ビルマ合敬, 相思樹, ナンバンサイガチ, ムラサキソシン クハ, 茶, タイワンツバキ，オホシマサザンクワ，八スノハギク，錫蘭肉 桂, ハリギリ, 鳳凰木, オホボンデンクワ, 時計草, キバナケフチクタウ の種子油及其脂肪酸の性䟮に就て試驗し，又上記アカギ種子油の成分を檢 索し, 其脂肪酸はリノレン酸, リノール酸, オレイン酸, パルミチン酸よ り成り，不鹼化物は主にフィトステリンより成るてとを碓めをり。又加福 均三，畑忠太网氏（同上 $439 ， 1120$ ) は臺灣蓙木瓜種子油中に脂肪酸成分 として，オレイン酸，パルミチン酸，ステアリン酸，アラキヂン酸を檢出 し，不鹼化物成分としてフィトステリン以外に脂棜屬アルコールの存在を 認め, 又臺灣斊泊桐種子油の脂肪酸はパルミチン酸, ステアリン酸, オレ イン酸,リノール酸より成り, 不鹼化物は主にフィトステリンより成るこ とを確めたり。本友恒氏(農化 8, 666) は前報に引續き米酒油の研究をな し, 本報に於ては $\mathrm{C}_{6}-\mathrm{C}_{14}$ の脂肪酸に關して研究し $\mathrm{C}_{6}-\mathrm{C}_{14}$ の偶數炭素 脂肪酸は $2-2.5 \%$ にして, $\mathrm{C}_{7}-\mathrm{C}_{9}$ の奇数炭素脂肪酸は存在せざることを 明かにせり。小野豐樹氏（同上788）は鮫卵上り得をる脂肪の性狀，成分 に關し，櫻井芳人氏(同上 1312) は味喻の油脂の性狀に關して報告せり。 又三木昇二, 讨良正一兩氏（同上 1313）は滿洲產綠豆油の脂肪酸成分と して, オイレン酸, リノール酸, リノレン酸, パルミチン酸, ステアリン 酸及アラキヂン酸を檢出せり。橫山良國, 鈴木文助网氏 $(P . I . A .8$, $183,358,361)$ は人の腦盛中のフ ォスフ チチドに關して研究し 4 種の レシチン及 4 種の $\beta$ ーレシチンの存在を認め, 岡田郁之助氏（水講 28, 106) は鮁油の臭化グリセライドを溶劑にて分別し9 種の臭化グリセライ ドを分離せり。岡野公次, 小原䈆兩氏（南䒽試 16,1）は大豆油抽出法に 
於ける酒精可溶部中のフォスファチドに就て研究し, 服部健三, 妹尾争磨 兩氏（熦化 4, 237）は牛乳中の脂肪に就て 報告せり。外山修之氏（東工 試27，2號39，71）江巨頭鯨油の成分飞就て研究せり。其結果に據れば腦 油の不揮發脂肪酸（油の約 $55 \%$ 冲飽和酸は主にパルミチン酸，ミリスチ ン酸, ステアリン酸, ラウリン酸上り成り, オレイン酸列の酸はゾーマリ ン酸, オイレン酸及び 1 種のエイコセン酸上り成り,オレイン酸列上りも

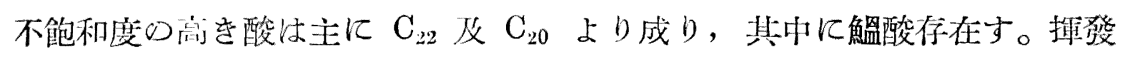

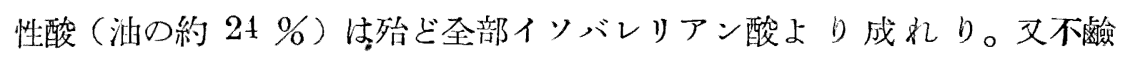
化物は大部分七チルアルコールょり成り, 其他 $\mathrm{C}_{16}$ 以下及 $\mathrm{C}_{16}$ 以上の飽 和アルコール, コレステリン, オクタデセノール存在す。體油の脂肪酸中 には上記の脂肪酸以外氏アラキヂン酸, ベへニン酸, ベへニン酸より高

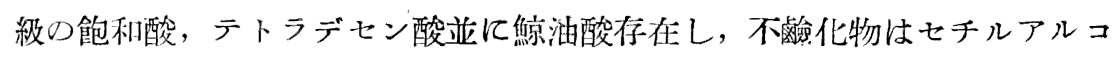
一ル，オクタデカノール，オクタデセノールの他に，コレステリン及沸點 芸だ高き粘稠物筫より成れり。猶同氏は海豚頭油の混合脂肪酸中のイン バレリアン酸を水に易溶性の監類となし之を水溶液狀態に保ちてイソバレ リアン酸以外の高級脂肪酸と分離せしむる方法を考案せり。秋山五郎九氏 (東工試 27, 11 號 75) は巨頭鯨油よりイソバレリアン酸エスデを製取 する方法を考案せり。又外山氏は土屋知太郎氏（同上 1，23）と共に伊豆 諸囟産椿油及九州墑椿油の性狀を試驗して兩者の異同を明かにし, 又數種 の支那產茶油の性狀に關し、て試驗せり。又本邦產安石榴, 水蠟樹, 南天, 粗概の種子油の性枵, 成分に就て研究し, 安石榴種子油の脂肪酸は主とし て $\propto$-エレオステアリン酸の未知立體異性能と考へらる〉酸より成れるて とを確めをり。土屋知太郎氏 (東工試 27，2號 75; 11 號 34，41）は鰮 油の高分子量固體酸に關して研究し，ノルマルテトラコサン酸及其同族 體の混合物の存在すべをてとを推定し, 又鯨油酸の存在を確めたり。又同 
氏は 9 種のブラジル產植物油脂, メキシコ產コーフン油, セレベス島產》 ルカス油及麻實油より析出する蠟の性㓠, 成分几關して研究せり。紀喜一 郎氏（本誌 35,682 ) は解油中の固状グリセライドの成分に關して研究せ b。

油脂類の成分に關係ある化學 丸山勉, 鈴木文助网氏 (P. I. A. 8, 186) はリノール酸より得たるテトラブロモステテリリ酸よりデブロモ並にモノ ブロモ化合物を製取し，之を酸化して酸化生成物を檢索し，テトラブロ モステアリン酸の立艠構造を推定せり。外山修之，土屋知太郎网氏（東工 試 27, 2 號 1，19）は鰮油中の高度不飽和酸に關する研究を繼續し，ヒ ラゴ酸メチルの過マンガン酸加里に依る酸化分溉及オジニド法に依る分解 を行ひてヒラゴ酸は $\mathrm{CH}_{3} \mathrm{CH}=\mathrm{CH}\left(\mathrm{CH}_{2}\right)_{2} \mathrm{CH}=\mathrm{CH}\left(\mathrm{CH}_{2}\right)_{2} \mathrm{CH}=\mathrm{CH}(\mathrm{C}$ $\left.\mathrm{H}_{2}\right)_{4} \mathrm{COOH}$ なる構造式を侍するとと在確定し: 又 $\mathrm{C}_{18} \mathrm{H}_{28} \mathrm{O}_{2}$ なる酸を單 離して之にモロクチ酸なる名䊈を與へ, 其メチルェステル及ロダン化合 物のオゾニド法に依る分解を行してモロクチ酸は $\mathrm{CH} \mathrm{CH}_{2} \mathrm{CH}=\mathrm{CHCH}_{2}$ $\mathrm{CH}=\mathrm{CH}\left(\mathrm{CH}_{2}\right)_{2} \mathrm{CH}=\mathrm{CH}\left(\mathrm{CH}_{2}\right)_{2} \mathrm{CH}=\mathrm{CH}\left(\mathrm{CH}_{2}\right)_{2} \mathrm{COOH}$ なる棈造式を有 することを確定せり。井上吉之: 佐橋佳一网氏 (P. I. A. 8，371）は解油よ り得たる高度不飽和酸濃縮部のメチルェステルより $174 \sim 175^{\circ} \mathrm{C}(0.018$ $0.02 \mathrm{~mm}$ ) の溜分をとり，此溜分及元の部分的水素加戍物を過マンガン 酸加里にて酸化分解して，鰮酸 $\mathrm{C}_{22} \mathrm{H}_{34} \mathrm{O}_{2}$ の構造式は $\mathrm{CH}_{3}\left(\mathrm{CH}_{2}\right)_{2} \mathrm{C} \equiv \mathrm{C}$ $\left(\mathrm{CH}_{2}\right)_{5} \mathrm{CH}=\mathrm{CH}\left(\mathrm{CH}_{2}\right)_{2} \mathrm{CH}=\mathrm{CHCH}_{2} \mathrm{CH}=\mathrm{CH}\left(\mathrm{CH}_{2}\right)_{2} \mathrm{COOH}$ なるべさ とを絬論せり。

木村和三郎氏(本誌 $35 ， 643$ ) は脂肪酸つ確認誘導䯠としてフェナシルェ ステルを選び，オレイン酸，エルカ酸，鯨油酸に就て $p$ ークロルフェナシル エステル, $p$-ブロムフェナシルェステル, $p$ ナフ ニルフェナシルエステル

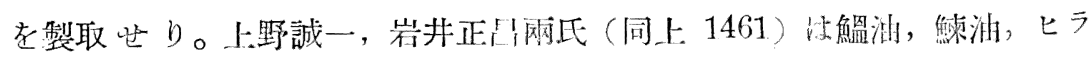


ガシラ肝油の脂肪酸及鱝油より分離让る高度不脃和酸より生ずる不溶性沃 監化物及沃臭化物の組成圭明かルし, 又 15 種魚油脂肪酸に就て不溶性沃 監化物の生成量を测定し, 又亞麻仁油脂肪酸上り生吉る不溶性沃臭化物に 關して試驗せり。

水素添加 田中芳雄, 小林良之助兩氏(本誌 35，52) は脂肪油の高壓水 素添加に際して反應メデウム中に酸性白土を其特殊の吸着性を保有せる狀 態於て存在せしむるときは水素涯加反應が著しく促進せらる」こと在確

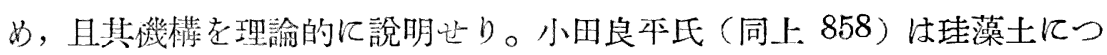
けたる銅党觸媒之なし, ステアリン酸, ステアリン酸エチル, 大豆油, 苳 麻子油, 柳子油, オリーヴ油の高壓還元を行ひたる實驗結果を報告せり。又 上野誠一，山崎利一郎爾氏（同上 1235）は脂油硬化汇於て生亦る有臭揮 發性物質中の脂肪酸成分を檢少し, $\mathrm{C}_{4}-\mathrm{C}_{7}$ 及 $\mathrm{C}_{14}-\mathrm{C}_{18}$ の饱和脂肪酸の存 在を認めをり。又上屋知太郎, 石川得三兩氏 (東工試 27, 11 號 53) はリ ノレン酸メチルの水素源加の過程に就て研究し, 不饱和度证江二重結合の 位置に關する選擇的水素添加を吟味し, 叉リノレン酸メチルの部分的水素 加成物中に存在するオクタデセン酸の化學的構造に關して報告せり。

硫酸化油 猪口金次郎, 五十嵐正次, 八木彌六氏等(本誌 35，429)は硫 酸化油汇關する研究を繼續して硫酸化油を硫酸エステル部と不硫酸エステ 儿部とに殆に゙定量的に分別し分別各部の組成，性狀老研究し，又夫等の關

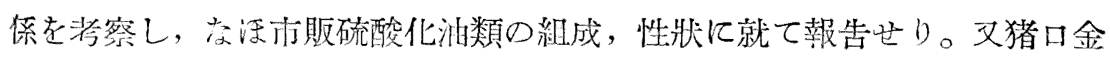
次郎，八木彌六雨上（同上 437) は市販硫酸化油中の硫酸エステル部並に 脂肪酸部曹達監の水溶液の性狀江就て研究し, 又猪口金次郎氏（问上 443） はリシノレイン酸及リシノレイン酸硫酸エステルの種々の條件下に於ける 安定度並に其變化生成物の組成に就て研究し, 又リシノレイン酸硫酸エス

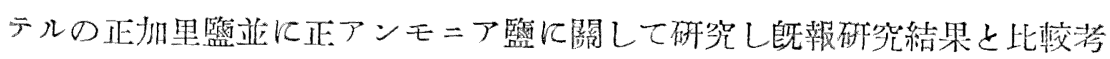


察し,兩者が正曹達監と相似の性質を有するととを確めをり。西濢恭助, 富 场壽夫网氏 (同上 1368) はセチルアルコール硫酸エステルの 5 , 種監類を 純粹に製取し，夫等の絬晶學的性質及び種々の溶風に對する溶所度を試 驗し, 又西澤恭助氏（同上. 1375) は上記 5 種鹽類の 水溶液に就て $25^{\circ}$, $50^{\circ} \mathrm{C}$ に於ける粘度，ケロシン及空皮に對する界面张力老测定し，リシノ レイン酸曹迋又はリシノレイン酸硫酸エステルの純粹なる各種監類と比較 せるに滛に强力なる表面張力低下作用を有するてとを確めをり。

酸化, 重合及其他の研究 田中芳雄, 中村三男网氏(本誌 35, 207) は留

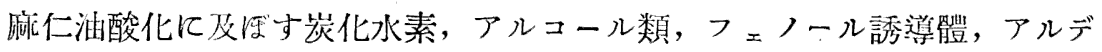
ヒド類，ケトン類並に酸類 31 種の作用及其程度を比較研㠰し, 福島郁 三，堀尾正雄，三木敏夫氏等（同上４01）は亞麻仁油酸化に對する紫外線 の影響に就て研究し, 光線恃酸化促進的に作用する中閒歶或は加熱により て容易に變化する中間绸の生成に役立つべきととを考察せり。又山口文之 助氏(日化 53，54，63，1134) はオリーヴ油に就て油酸銅, 油酸鉛, 亞彨 仁油酸マンガン等の不飽和油の酸化に對する 正触媒の潜伏時間及潜伏時 間後に起る油の一次反應的酸化速度に及在す影響を試驗し, 又トリオレイ ンの酸化に就て酸化防止劑の存在せざる場合及 $\alpha$-ナフチラミン，ヒドロ キノン, 油酸銅の存在せる場合を䁈噞し, 又油酸の酸化に就てヒドロキ) ン，油酸銅の影響を研究せり。紀喜一郎氏（理硼報 11，477）は高度不 飽和酸メチルェステルの加熱重合に於て 溫度及 稀釋劑添加の影響を研究 し, 高溫度に短時間为熱するとき,又はパラフィン其他の無作用物質の多量 にて稀釋する場合に 1 分子內に 4 炭素環を有するモノカルボン酸を多量に 生成するととを確めたり。小田良平氏(本誌 35，1271) はオリーブ油にエ チルアルコール，グリセリン及ェチレングリコール㠻作用せしめ，又楖子

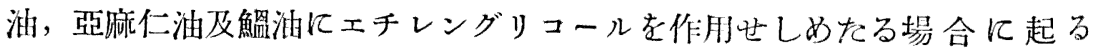


ウムェステルングに就て研究し, 土屋知太郎氏(東工試 27, 11 號 45) は 荜麻子油に各種油脂の混合脂肪酸及口ジンを添加し，之を加熱したる場合

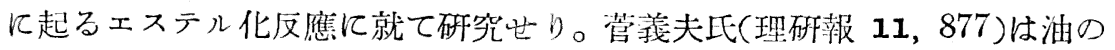
粘性に及はす壓力の影響に就て研究し, 小含正照, 道上重雄, 春日井忠一

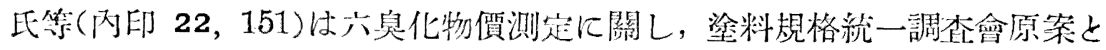
アイブナー及ムーゲンタルラーの方法とを比較㸴笕せり。其他農林省農務

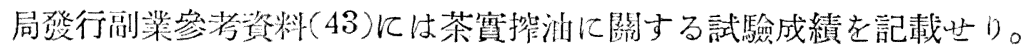

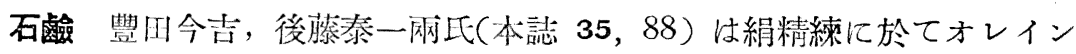

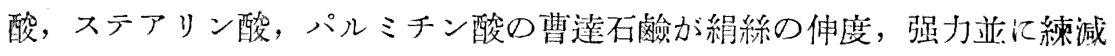
率に及ぼす影響に就て吟味し, 又豊田今吉, 山本隆治兩氏（同上 93）は 上記 3 楮の石䲓に就て絹精練浴中に於ける比粘度, 比傳導度を檢せ门。川 上八十太氏（同上 61，323）はニートソープの凝固點を测定して之と脂肪 酸との關係式を提出し, 又枠の中心に筑けるニートソープの溫度の變化を

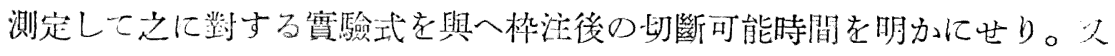

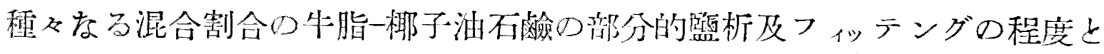
分別鹽析との關係江就て研究せり。角替利策氏 (本誌 35，407，1010; 農

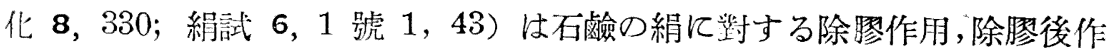

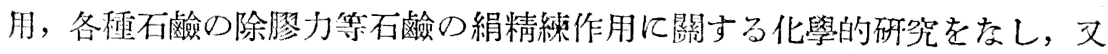
尾川岸太氏(絹試 6,2 號 1)は絹練石簽の變質防止に就て研究せり。

\section{5. 精油, 香料及化粧品}

精油成分炤和 7 年に於ける精油成分の研究は比較的少し, 北島正榮,

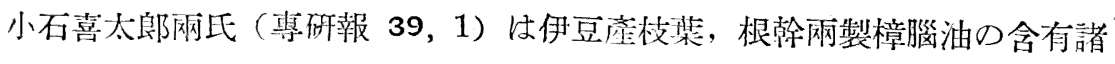
成分の墓異に就て研究し、枝葉製油は根翰製油に比しシネオールの含量少 く, $\beta$-ピネン及カンフェンの含量多き傾向あり。 $\alpha$ ーピネン，ヂペンテン， 
フェランドレン等には大差なきてと票れり。枝葉製油の中沸點溜分は主 として 有量少く,根幹製油はこれに反しサフロールを主成分とすることを知れり。 加福均三, 池田鐵作, 藤田安氏等(日化 53,636) は臺灣㖉ジャバシトロネ ラ油りセスキテルペン及セスキテルペンアルコール溜分に就て檢索し, 七 ステキテルペンにカデネンの一新異性能を發見し $\gamma$-カデネン $(\gamma$-Cadinene) と命名し其の丵浩式を發表せり。セスキテルペンアルコールは主としてエ レモール(Elemol)より成るてとを認め，售ほカダレン系セスキテルペンア ルコールとして $\gamma$-カデノール( $\gamma$-Cadinol)及シンボポール $($ Cymbopol)の 2 種の二環式七スキテルペンアルコールの存在することを報告せり。藤田 安二氏(日化 53，650）は前記臺灣産ジャバシトロネラ油の成分に就て生化 學的研究を行ひ，植物の場所に低る含油量の差異，植物の成辰日月と成分

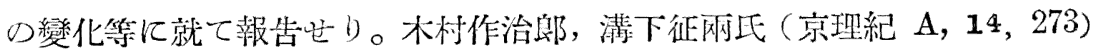
は日本杉油中の七スキテルペンとセスキテルペンアルコールに夫ぬキガネ ン(Kiganene) 及キガノール (Kiganol) の名稱を與へ，パラヂウムアス ベストに依る接䚡酸化還元，オジン酸化等に任り夫等の構造式を提案せ り。高原知義, 真鹽薘男兩氏 (神工試 2,1 ) は薄荷油の粘度とメントー ル含有量との關係に就て實驗し薄荷油の粘度よりメントール含有量を 推知し得べきとを老報告せり。朝比奈泰彥, 中西莊吉氏等(藥學 52, 1 ,

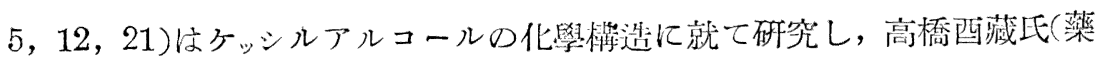
學 52,61) はアララギ某の成分タキシニンの構造に就て 研究結果を報告 せり。

オイゲノル, ワニリン系化合物の硏究 サフロールよりイソオイゲ) 一ル及ワンリンを合成する研究は前年に續き比較的多数に發表せられたり 平泉貞吉氏（本誌 35，129）はサフロールをメチルアルコール及菏性加里 
と共に加厴下に加熱分解して得らる」フェノール性化合物のベンジェート

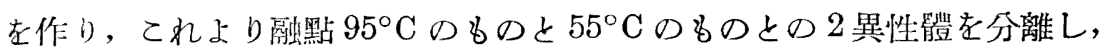
前者はメトキシイソオイゲノールのベンジェートにして, 後者はメトキシ イソオイがノールのベンソェートなるてとを證明し, 更に兩ベンジェート の融點明線を作り，更に又サフロール分解生成物を醋化して 4-Propenylcatechol diacetate 製し, てれをアンモニア瓦斯にて處理して Propenylcatechol を好收率にて製造し得ることを報告せり。本尾子之吉氏（日化 53，479) はサフロールを苛性加里と $n$-ブチルアルコール及アミルアルコ ールと共に加熱分解してブチロキシイソオイゲノールと, ブチロキシイソ カヴィベトールの混合物及アミロキシイソオイゲノールとアミロキシイソ カヴィベトールの混合物を製し, 佮 2 個のフェノール基がアルキルエーテル となれる場合アルキル基の種類とグリニアール試樂に對する安定度に就て 研究結果を報告せり。同氏 (日化 53，488）は更に 2 個のフェ)ール基がア ルキルェーテルとなれる場合にグリニアール試睬に對する安定度をグアヤ コール及同族體のェーテルに就て研究し，3の位置より4の位置がより容 易に侵されてフェノールと枋りアアルキルェーテル基とアルコオキシメト キシ基が共存する時は位置に關係なく不安定なる後者の侵さるうことを知 れり。猶これら一族の香に就ても記載せり。同氏(日化 53,696) は叉4Ally-catechol dimethyl ether (Allyl veratrol) 苛性加里とメチルアル コールにて加熱分解する時はアリル基に對しパラの位置がより多く侵され てイソオイゲノールを多量に生じ, 4-Ally-2-methoxy-1-ethoxyl benzene 又は 1-propyloxyl benzene の場合は 2 のメトキシル基がより多く侵さ れアルキル基とベンジル基の其存する時は結合位置に關係なくベンジル基 のみ侵さる」ととを報告せり。同氏（日化 53，485）はイソワニリンの誘 導娟數種老合成し其つ性質, 收量等に就て報告せり。 
カンフェン及龍腦に關する硥究 藤田安二氏(日化 53, 847)はカンフェン ○五酸燐及燐酸に依る異性化に就て研究し, 異性化テルペンとしてカレン

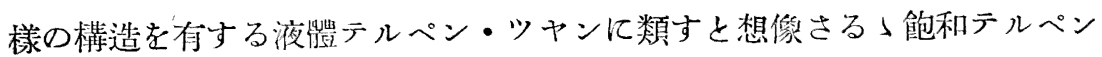
及び 2 分子重合に依るデテルペンの生成を認め, 液嵀坫カンフェンの存在を 否定一證左となし, 又カンフェン无现酸燐と硫黄にて處理しシモールの生 成するととを報告せり。桑四勉, 立開静网氏(本誌 35,773) はカンフェン と葆酸との反應に依るイソボルネオール葆酸エステルの生成と珪酸ゲルの 接觸作用に就て報告し, 玨酸ゲルはカンフェンと葰酸との反應を藷しく促 進し得るるェステルの生成量は $75 \%$ 以上に達し難をを知り,カンフェンと 蓚酸より中性エステルを生ずる反應階梯孛檢索し, 次の可逆反應の存在せ

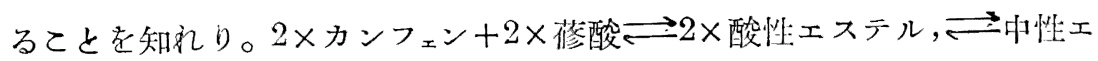
ステル十蓚酸。山田清一, 山田澄网氏(日化 53，807) は龍腦及イソ龍腦の

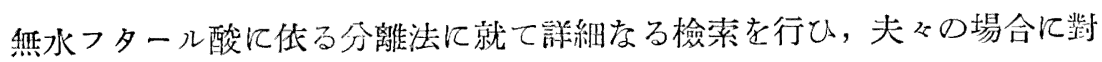
し㷛水フタール酸の量, 反應溫度, 反應時間の最適條件を定尚, 佮てれら の反應よりイソ龍腦を第三アルコール型とするょりも寧ろ龍腦のエンド型 と考へるを穻當なりと述べたり。

テルペン化合物の接觸異性化其他 木村清三氏（日化 53，497）はゲラ ニオール及リナロールを活性炭と其に高溫に處理して水分と油分の生成す るととを認め，低沸點部にミル七ン，ヂペンテンを檢出し，高漂點部にヂ テルペン及其の酸素化合物の存在するを認め)たり。同氏(日化 53，777)は 續いてシトラールを活坐炭と處理して生成物中にシモール及 $\mathrm{C}_{20} \mathrm{H}_{29}$ の炭 化水素を檢出し，シトロネラール慗同樣處理してイソプレゴール，ヂイソ プレゴールェーデを檢出せり。

藤田安二氏（日化 53，871）は核中に於ける二重絬合，水酸基害位位置

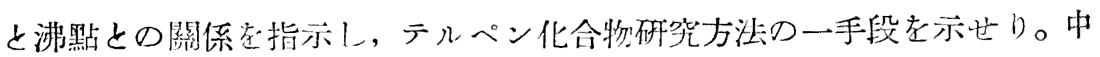


土晃氏 (本誌 35,915 ) ヂペンテン, 環归テルペンアルコール，リナロー ルと硫黄との反應状態, 告成物等に就て報告せり。

\section{6. 印刷及印刷インキ}

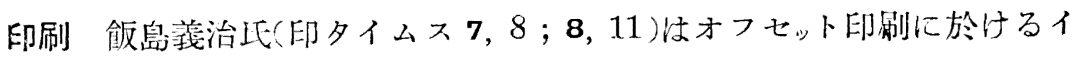
ンキの盛り方，インキの硬さ，水上インキの紙面への落付，スクリーンの

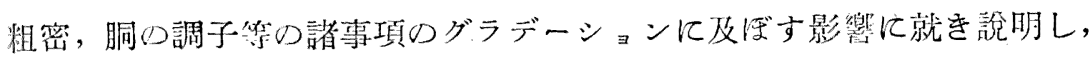
濑本作次郎氏（印师 15，10 號 49）は金銀色インキ印刷の際の注意事項 を述べたり。

印刷機 俳藤亮治氏 (印時街 80 號 18) は多色オフセット用コンポーザ 一の最近數年間の進步發造に就き種類を舉げて說明せり。矢野失氏（印刷 15，10號 17)は獨逸フォマック社の新考案になる無熱乾燥裝置に就さ說明

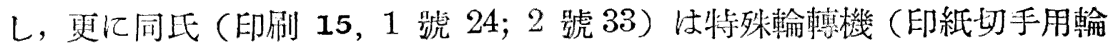
喠機の䕀嚄印刷機，ゴム版印刷輸輤機）に就て說明せり。岡崎俊吉氏 (印洔報 83 號, 8；84 號 10) は製本及紙器に使用する各種の機械に就き 說明し, 勝島喜一郎氏 (印時報 84 號 6) は高速度輪權印刷機に就き說明 せり。

活字金、青木信利, 池田次郎网氏（內印 22，1）以活字合金の研究，第 $7,8,9$ 及 12 報として 鉛アンチモン錫合金の磨滅度, 融娟及固體の熱膨 脹係數, 凝固の際に於ける罷積の變化, 並に营溫に於ける密度の測定圭な ᄂ, 青木信利, 脇昌次郎兩氏（內印 22，55; 印刷 15，9號 12；11 號，12）

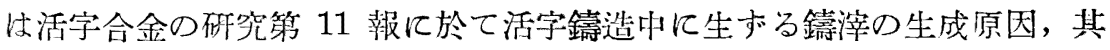
の出來る量並に其成分組成を明加飞せり。青木信利氏（队印 $22 ， 61$; 印 刷 15，5號 21）は活字合金の研究第 10 報に於て活字及鉛版鋞造に必要 なる地金の物理的性質並に其等の鑄造上に現れる種々の現触例へば彭, 鉛 
版の反り，鑄㳯等の說明をなせり。

顏料 古田迪氏(內印 22，143) はリソールレッドの製造研究に於て其中 間醴なるトビアスオキシ酸及トビアス酸の製造に各メ夕硼酸及亞硫酸アン モニアを䚡媒として 使用し其生成量を增加せしめ，且ヂアゾ化及カップリ ングの最良條作を求めたり。次にレーキ製造の際の沈澱劑の色彩に及慓す 影響を檢し, 佾中間體並に色素の性質を檢し, 且色素の吸光係數曲線を求 めたり。白土萬次郎氏（顏塗インキ 6，75）は印刷インキ材料としての觀

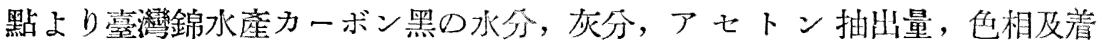
色力, 夾雜物, 比重, 吸油量を测定し, 且䨘地試驗を行ひたる結果を報 告せり。

ワニス 小含正照, 道上重雄网氏（內印 22, 115）は燒ワニスの研焭第 5 報に於て亞腋仁油を炭酸瓦斯導入により空氣を遮斷し $345^{\circ} \mathrm{C}$ (燒ワ=ス 製造の際の溫度) 及 $295^{\circ} \mathrm{C}$ (塂ワニス製造の際の溫度)に扣熱し屈折率, 比 重, 粘度, 鹼化價, 酸價, 不唖化物, 沃素價, 六臭化物價, アセトン不溶 物の量の變化を比較せる結果, 兩者間に著しき相違點が存在するのみなら ホ $345^{\circ} \mathrm{C}$ に加熱せる油は種々の點に於て燒ワニスと近似せる性狀を具䚚 する事を認め，假に“高溫煎油”之命名出り。又同氏等(们印 22，125) は燒ワニスの研究第 6 報に於て燒ワニス製造工程中に於ける油の溫度を测 定し, 且煮ワニスとの性:狀の相違を明かにする䈍, 网者の製邀工程に採取 せる試料及製品の多數に就き比重, 屈折率, 粘度, 酸價, 畧化價, 沃素儨, 不䲓化物; 酸化酸を測定して比较せり。佮屈折率より比重算出に便するた め實驗式を作製せり。小倉正照氏(顏塗インキ 6,331; 化工時報 5, 27 號 6, 28 號 15) はスタンド油の沿革, 製造法の變遷を解恱し其進化過程を 明かにし新工夫に對与る暗示を與へたり。福岛郁三, 堀尾正雄, 三木敏 夫氏等（本誌 35，401）は亞麻仁泊を低溫 (5 及 $20^{\circ} \mathrm{C}$ ) に於て酸素を吹 
込みつ」水銀燈光線に照射したる後比較的高溫 $\left(55^{\circ}\right.$ 及 $\left.70^{\circ} \mathrm{C}\right)$ にて酸素 を吹达みて酸化し沃素償の變化老測定せる結果, 露光せし油は其特數に著 しき變化なきにもか子はら亦速か几酸化する事を確的, 光は油に對し酸化 促進作用をなす中間體の生成に役立つのであるとをせり。

印刷インキ 山本伊得雄（印刷 $15 ， 8 ， 51$ ） は金銀赤インキを水酸化ア ルミニウム, 硫酸バリウム, 炭酸カルシウムに依つて稀釋せる場合混合量 小なる間は色相の變化極めて少く約 $20 \%$ ょり急激に變化す，而して水酸 化アルミニウムにて稀釋叫る場合は他の 2 者にて淡めた場合と異なる事を 述へ，各淡色劑に低り淡まる爿態に差異あるは各淡色劑の比重の相違に原 因するものと推論し，更に黃鉛インキと紺青インキ，金赤インキと黄鉛イ ンキ，紅赤インキと緗青インキの混合世る見本を示し，且プロ七ス及三色 版の場合飞就て此礼と同一飞論市るを得ざる理由を說明出り。松浦武夫氏 （印時報 86 號 4) 纱印刷インキに就き一般科學的考察を高し, 村上義比 古氏（印タイムス 8 號 4,9號 11）は黑インキの裏污れの起る原因其イ ンキの成分性狀との關係に就を考察し防止法几就き說明呕り。伊藤敏雄氏 (印刷 15, 12 號 6)はエマルジョンの理諭, 實例, 製造方法及エマル ジョンインキの將來に就を說明し，其研究に對する暗示を與へたり。

ゴム 山本魁介纸（印刷 15，3 號 27）は印刷用ゴム飞必要索る基本的 要件として (1)油性インキの侵害に渜动る事，(2)インキ附着性大なる事， （3）インキを附着し難き性質の 3 要件を舉げ，之を基調として研究せる結 果を述べたり。郎耐油性を與ふる方法としては（1）硫黃の添加量を多くす る事，(2)充塡物を多くする事，(3)人造ゴム製造に於て根本的に耐油性物 質たらしむる等，(4)ゴム粒子被璬性の耐油コロイド物質を適當に混和する

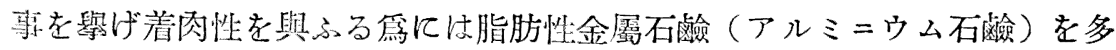
く添加する事に依りインキとの親和力を增大世しめ, 又反對にインキを附 
着せざる性質を與ふるためにはゴム中に水銀よアマルガムを構成し得る物 質（アルミニウム）を加へて和硫し竹品としたる後其面に水銀を塗着せ り。向本版用ゴムローラーに關する私見を開陳比り。

規格 (亞麻仁油)小倉正照, 道上重雄, 春日井忠一比等(內印 22, 151)

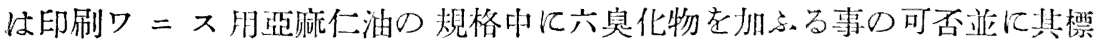

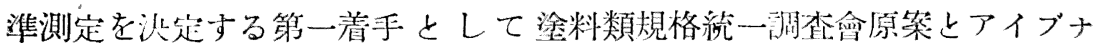
ー・ムッダンターレル法と比較し，次で臭化物洗滌の方法に就て蛽驗岀る

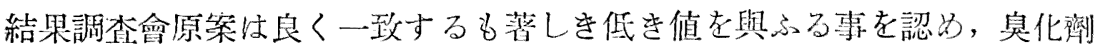
中の醋酸が六臭化物析出を阻害するためなりとせり。（用紙）矢野道也氏

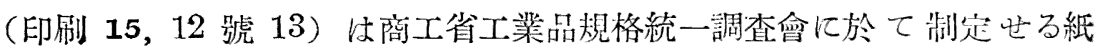
の分類規格案に就き詳細に說明せり。州紙標準化委員會(商工省) 校事務朋 封筒寸法及事務用紙仕上寸法に對する規格案を作整出り。(色彩) 矢野道 也氏(印刷 15，9 號 21; 10 號 26; 帝工藝 6, 11 號 356) は色彩心標準

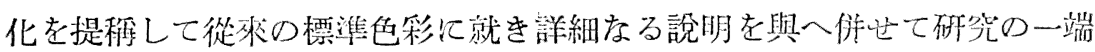
老開陳出り。(活字) 水沼辰夫氏(印刷 15，11 號，5) は活字規格統一儿就 て矢野道近氏の案在批制し, 號數活字に現行ポイント式老當てはめる案在 提出せり。

\section{7. 顔料, 塗料及樹脂}

顏料 白土萬次郎氏(顏塗インキ 6，75)屾印刷インキ忉料としての臺灣 䤼水產カーボン黑（コーモリ印）の品質汇就て侙驗し該品は米國鑛山局り 明細書に合格し，トライアングル印と比較し著色が少しく劣れると吸油量 秒々多き以外に色相其他に於て寧ろ勝り良質のインキを製造し得るてとを 述へ，猶印刷インキ用としては水分，灰分，アセトン抽出量，色相及著色 力, 砂利試驗以外に比重, 吸油量, 流展性を試驗する必要あるを說き, 最 
後にコーモリ印カーボン黑製造者に裂品の改良に關し 2,3 の希残を述べ たり。仙波猛, 伊藤貞志兩氏(本誌 $35,1178 ， 1184$ ) はゴム用カーボン品 の吸着性能飞就て報告せり。

染料 小倉正照, 道上重雄兩氏(印刷 22,115 ) は亞麻仁油を $295^{\circ} \mathrm{C}($ 者 ワニス製造の溫度)及び $345^{\circ} \mathrm{C}$ (燒ワニス製造の溫度)に炭酸瓦斯氣中に於 て加熱し, 鹼化價, 酸價, アセトン抽出量, 比重, 屈折率, 比粘度等を測 定し, $345^{\supset} \mathrm{C}$ の場合は 30 分前後に於て諸性狀の急激なる變化を起し反應 が 2 段に進行することを知り， $295^{\circ} \mathrm{C}$ の場合は斯かることなく直線的に變 化し第 2 段に相當する化學的變化の起らざることを認めたり。兩氏（印刷 22，125）は更に燒ワニスを工業的に製造し，工程中の油の溫度を湘定し， 續いて燒ワニス, 蓔ワニスの製造工程中より試料を探取して其比重及屈折 率を测定し，屈折率より比重を算出する工業用實驗式を作製せり。猶ほ製 造工程中の酸價, 簽化價, 沃素價, 不簽化物, 酸化酸等の變化をも測定せ り。荒椎雄, 長表貞二兩氏（本誌 35，167）は飛行機翼塗料としてのべ ンジル纎維素の性質を知るな゙ I. G 會社製ベンジル緎維素の各種混合溶 劑飞對する溶解度を測定し, 各種溶劑の特徵に就て報告し, ベンジル瀻維 素はエチル繊維素に比し翼布緊張力は大なれぞる梁縮性, 皮膜の濕氣に對 する抵抗力は劣れるととを知れり。廣瀬誠一氏(顏塗インキ 6, 361) は油 ワニスの不揮發分中の油とレジンの割合, 耐撓力, ワニス皮膜の挡裂, 老 化，耐候力等の間に密接なる關係あることを述へ，耐撓力を檢する目的に て考案されたるカウリ稀釋試驗が耐候力の推定にも役立つてとを實證し， 我國に於てカウリ稀䆁に類する試驗を實施する前提として, 我國に於て得 易きカウリの代用とし得べきレジン類に就て該試驗原料としての長短を檢 し, 石灰硬化口ヂンがカウリ代用とし最適品なりとせり。齋藤定藏氏（顏 整インキ 6，24，189)は船底に附着する生物と其習性に就て報告し, 船底 
塗料製浩者によき參考資料を與へたり。

樹脂 小田良平氏（本誌 35，340）はコーパル熔融に際し其熔融損头を 輕減するため, ザンヂコーパル及コンゴーコーパルに就き栍々の添加劑の 影響，壓力の影䠹を檢し，添加劑として有效なりと記载され居るナフタリ ン,フェノール其他 $\beta$-テフトール, 生ゴム, パラフィン, 硫黃, 酒石酸等は 全く效果なく，ステアリン酸のみはコーパルに 10〜20\% 加へ $360 \mathrm{C}$ に 20 分間加熱する時，比較的良好なる絬果の得らるってとを報告出り。門膦 博明, 笠井圓爾兩氏 (大工試 13，1) は尿素及其の誘導䞍とフォルムアルデ ヒドとの縮合物の紫外線並に赤外線の透過度率に就て測定し，尿素縮合物 が最も透明度高く最短波長 $2300 \AA$ に及び, エチル尿素, メチル尿素緛合 物の透明度之に次き，後者の透明度は硝子と同程度なることを報告せり。 焰ほチオ尿素縮合物に完全に紫外線老吸收し, 赤外線部に於ては各縮合物 が夫々 $\mathrm{CH}$ 基， $\mathrm{NH}$ 基及び水に基因する數多の特殊吸收帶を示すことを 知风り。

\section{8.コム及コム類似品}

溶液に關する磁究 河村治郎, 田中國吉兩氏(本誌 35, 544)はゴム溶液 に對する沈澱劑の影響は複雜にして簡單に說明し得難をを報告し，同氏等 （本誌 35，549）は更にゴム溶液の溶媒和に及代与沈溉洖並に溫度の影響 そ就て實驗し，アセトン，アルコール類の如き沈澱劑は其の少量添加に依 りゴム膠質溶液の粘度を著しく低下せしむるも溫度の上景之共て却つて比

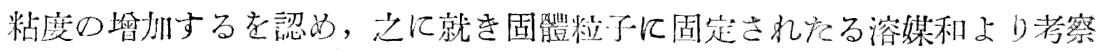
を行へり。島田處一氏(本誌 35，1188，1195，1201) はゴム溶液に䶘する 有機促進劑の作用に就て矽完し、ゴムのベンゾール溶液にアルデヒドアン モニア繀合生成物, アルデヒドアミン類, チオュレア類, グアニヂン類, 
ニトロソ化合物, チアゾール類, チアヂン類, チウラム類等に屬する各種有 機促進劑を添加し粘度の變化を圖示し,其結果を總括して, 促進齊を $\mathrm{A}, \mathrm{B}$, C の 3 型に分類し， A 型はゴムに影響なく， B 型はゴムのデアグリゲー ションを，C 型はゴムのポリメリゼーションを起さしむるるのとなせり。

硫化, 熱處理, 硫化促進劑等に關する研究 波田强一, 中島武治兩氏(護 謨 5，75)は生ゴムの加熱曲線に就て報告し，セイロンクレープ,ペールク レープ，スモークドシート，ペールシートの4種の試料に就て實驗せる結 果70〜 $100^{\circ} \mathrm{C}$ 間に於ては著しき熱效果を示さざるととを示せり。同氏等 (護謨 5，288)は續いてゴム硫黃系の硫化に於ける加熱曲線に就て觀察し， 先づ加熱の初内に硫黄の熔融に依る吸熱變化あり, 續いて生ゴムの硫化に 低る發熱反應あり，乙の發熱程度はゴムに於汀る硫黄の理論的飽和點まで 硫黄の配合量に比例して增大し，硫化反應の發熱現售は全行程中 1 回現は るっのみにして，ゴムの硫化は 2 段以上に進行せざること等を認めたり。 藤原竹雄, 並水敏雄兩氏(護謨 5,523) はゴム一硫黃系硫化ゴムを $160^{\circ} \mathrm{C}$ に於て加熱し，加熱時間に對する榙分析量の變化，アセトン,クロロフォル 厶抽出量, 全硫黃, 遊離硫黄, 結合硫黃, 樹脂質, 重量等の變化を觀察せ 门。岛田嚰一民（護謨 5，420）は有機促進劑ウルカチットFの組成に就て 各種定性試驗, 㳬量試驗, オレイン酸コバルトに依る呈色反應等より判斷

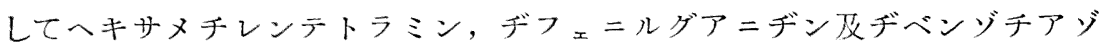
一ル・ヂスルフリドより成るとと立觀察し，其組成割全は夫及 $23.5,8.8$ ， 64\% なることを報告せり。村木勇夫氏(護謨 5，309)は生ゴムの挸練程度 に任る加硫ゴムの品質の變化が物理的なるや或は化學的なるやを明かにせ んとして賽驗し, 揘練程度の測定には該生ゴム $1 \%$ のベンゾール溶液の粘 度を测定することの便利なるととを知り，揘練度と加硫ゴムの硬度，扯剪 力，化合硫黃量等在测定讦り。その結果ゴム揑練はゴムに單に物理的變化 
を與へ，加硫ゴムの物理的性質にのみ影響し化學的性筫には何等の關係な きを知れり。岛四慶一氏(訬謨 5, 695) は準超有機促進劑として取扱はる るウルカテット 576 のゴムベンゾール溶液の粘度に及代す影響は他の準超

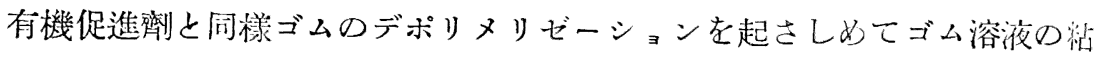
度を降下岂しむるととを發見し,ゴム硫化に於ける該促進劑の特異なる促 進作用は該デポリメリゼーション作用に基因する事大なるべきを推論せり。

老化に關する硎究 山崎武二, 奧山夏六网氏 (本誌 35,706) は遊離硫 黃の老化に及汪与影響に就て考察し, 遊離硫黄の多察が必尗しも老化後の 性質を乿想すべき標準さはならず，デフェニルグアニヂン及ヂオルト・トリ ル・グアニヂンを促進劑として用ひたる場合もての推定に變化なく,ゴム 製品の耐久性の判定には遊離硫黄量に依るよりる適當なる老化試驗に依る ことの一㞒合理的なるを指摘セり。沼尻清一氏(護謨 5,79)は加硫ゴム製

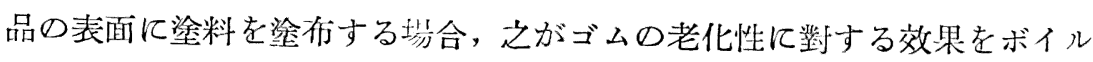
油, セルバ印ラッカー，金ペン印コーパルワ=スの3 種の塗料に就て實驗 し, 是等の鉒料はゴムの老化防止效力なく, 反つて塗料の稀釋劑なるガソ リン, ベンゾール，テレビン油等のてめ惡化の傾向あるととを示し䔈際家 の注意を唆起せり。

ゴム成分の分析, 定量に關する研究 內田壯氏(護謨 5, 67)はェボナイ ト中の鑛物質を定量するにセスキテルペン抽出法の有效をる事を提案し， セダー油を用ひてェボナイトの鏣物筫定量に良好なる結果を得をることを 報告せり。松本常太郎氏(東商 21，76)は黑サブ中の遊倠硫黃定量にアセ トン抽出を行ふ場合の諸注意事項に就て述べ, 潜谷视三郎, 大木七郎兩氏 (電試調 86, 1) 以總硫黄量と遊離硫黃量との差に依て求むる結合硫黄量の 不合理なること,更にてれを基礎とする硫化係數,ジム量算出法の不合理， 無意味なるととを指摘し,純ゴム算出法に關する A. R. Matthis 氏(1917) 
の方法を少しく改めて新算出法を示しその結果を呤味せり。

雜 石黑克己氏(護謨 5,72)壮透明ゴムを製邀する際, 透明性硫化促進

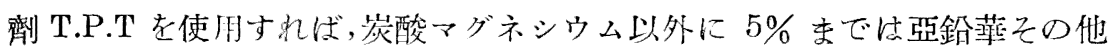
の配合劑を添加して，物理的性質の優良なる透明ゴムを製造し得らるって とを報告し, 同氏(護謨 5，570) は叉耐油性ゴムの製造に就て實驗し, 各 種配合のゴムを同一條件てて製し，之を油中に浸漬して其變化を觀察せる

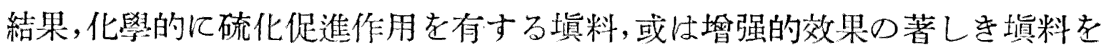
用ひたものは吸油量少く，油に溶解する傾向を有する有機埧料は最も不良

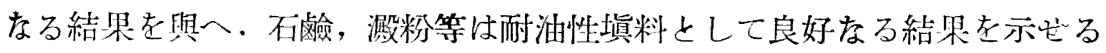
こと老報告せり。宇都宮偉氏(護謨 5，211) は加硫ゴム粉末及オ゙重炭酸ナ トリウム主配合として多孔賢性滤過材料を試製し, 其品質は獨逸製品と

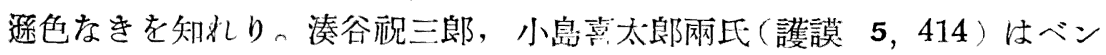
ジヂンをゴム硬化劑として使用する場合はメルカプトベンジチアッ゙ールを 促進劑上するゴム混合物に顯著なる硬化現皇を現屾し，硫化ゴムのモヂュ ラス及び扯断力を睤大し, 硬度及彈性は多量の無機填料を含むゴムの場合 は稍々增大寸れぞ为純ゴムの場合は影響顯著ならざることを報告せり。べ ンジヂンの最適量はゴム原料の $0.25 \%$ にして其使用に依り促進劑つ軟化 性老防止し更江硬化作用を呈し，而子硬化作朋の硫化後に殘留する影響の 極为て少きを認めをるも，ヘンジデンの酸化に依りゴム混和物几污染の生 和る缺點を指摘せり。仙波猛，伊藤貞志兩氏（本誌 $35,1178,1184$ ) は ゴム用カーボン黑の研究の一としてカーボン黑の吸着悱能汇就て賽驗し市 販品 9 称, 吸着岑 1 種儿就て D.P.G 赥性曹達, 醋酸, 沃素, マラカイト グリーン, メチレンブルー, 亞䐚仁油, 水蒸氣の吸着吸收の强さを求め, D.P.G 醋酸及び沃素に就ては吸着等溫曲線を求的, そ狆等の結果上り或種 のカーボン黑は酸性とアルカリ性に對し, 顯著索る選㯰吸着を示すことを 
㪕告せり。遠藤英黁氏（本誌 35,5 ) はゴムの燃燒熱を测定しパララバー 10761.0cal，スモークシート $10680.4 \mathrm{cal}$ ，ペールクレープ 10681.6eal なる ことを報告せり。

\section{9. 㵶維素, 紙及セルロイド}

木材化學 河村治郎, 谷口政勝兩比( 纖工 8, 25) は船材用の日本松, ク ロマツを海水中に5 ケ月間浸漬して化學成分の變化を分析し, 纎維素分の 減少, リグニン分の增加等を指摘し, 次に日本杉が空莱中に於て涙菌にて 腐蝕せる場合の變化を分析し，可溶部分の㫮加を認め，材質成分の分解變 化を追究せり。右田伸彥氏 繊工 8，187）はヒバ，クリ，モミ，ブナの木 材窝敗菌ポリア菌に對する抵抗性を試驗し，七バは抵抗性最も大にして， クリ，モミ之に次ぎ，ブナ材は最も腐敗し易き事索認め，木材の耐腐性物 質はアルコール，ベンゼン抽出物に存在し，精油其他が木材の抵抗性を大 ならしむる事を明かにし，木材をエーテルアアルコール, 溫水等にて抽出せ る前後の腐敗度の比較を示ぜり。

次に木材の化學的成分の研究に關しては, 志方縊三, 石崎道也丽氏（緎 エ 8, 121) はェゾマツ, ト、゙マツの植物學上の分類種别を述べ, その材 質の顯微鏡的組織走示し, 春材部, 秋材部, 其他の部分の化學分析結果を 羊し，更に人綟用パルプとしての適否を論じ，中村一元氏(纎工 8,145 ) は樺太產ェゾ松, ド゙松の化學的分析を行ひ, ド゙松はェゾ松に比し全㵶 維素約 $2 \%$ 少なく, 又 $\alpha$ 繊維素含量も少なきが, 此點がト、゙松蒸解の步 留の少なを原因をなすとせり。三浦伊八郎, 吉田定輔兩氏（纎工 8,143 ) はシャム産唐木たる紫檀, 黑檀, 鐵刀木, 花梨, 手違紫檀の組成を研究し, 其詳細なる成分を示し, 唐木は一般に抽出物の落量を含有し, 繊維素中の $\gamma$ よりる $\beta$ 繊維素を多量に含有するを見出し, 又鐵刀木杜普通濶葉樹に 
存在せざるマンナンを含有し, 紫檀, 鐵刀木, 花梨, 手違紫檀はガラクタ ンを含有せざるを認わ，此點は單子葉植物の竹及び棕櫊材に類すると述へ たり。上田嘉助氏 (䋐工 8, 169) はドロノキ, エゾヤナギの蒸煮試驗を行 ひ, 重炭酸曹達及び重亞硫酸蒸煮に附して得たるパルプを术材化學的見地 より比較し, 前㳂のパルプは後法のパルプよりも純纎維素に近く， $\alpha$ 繊維 素含量大なる事を認めたり。

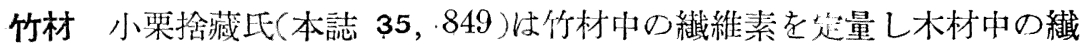
維素より含有量遥に少なきを見, $\propto$ 繊維素は相當多量のペントザンを含有 すれぼも，此のペントザンは $2 \% \mathrm{H}_{2} \mathrm{SO}_{4}$ にて 3 時間加水分解すれば殆ど 驅除し得る事老認妨り。同氏(早應化 第 17 號; 本誌 35, 990) は孟宗 竹の水溶性成分在研究世り。孟宗竹紛心熱湯抽出液老濃縮し酒精可溶分と 不溶分とに分占夫网同者に就て灰分, 空素分, 五炭糖, 六炭糖, 還元糖, 非還元糖等の分析並にオサジーン反應老試みフェニルオサジンの融解點を 測定せり。次に同氏（本誌 35，998）は孟宗竹纎維素の旋光性を測定する 笥に, 繊維素の酸化銅アムモニア溶液の調製法を研究し, 旋光性測定に用 ふる波長注 $436.9 \mu \mu$ となすべき事走決定し，更に(本誌 35，1004) 桂竹， 孟宗竹, 桂竹, 標準綿緋維素, ヴィスコース絹絲の酸化銅アムモ之一溶液

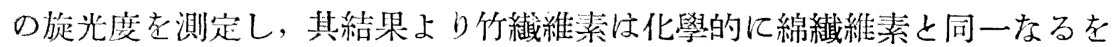
絬論せり。

ミッ゙ゴケ 志方益三, 渡邊護网氏(農化 8,949) は樺太產ミッ゙ゴケの化 學分析在行ひ, 繊維素定量を改良考案し分析の結果は繊維素量約 $29 \%, \alpha$ 繊維素約 $11 \%$ に過ざざる事, リグニンの含量は木材に比して少なく，外 觀は酷似すれ共， $\mathrm{NaOH}$ 溶液に對する溶解性蓄しく異にする事等を結 諭せり。

パルプ 河田普太郎氏(本誌 35，473) は市場にあるヴィスコース人造絹 
絲用のパルプを分析し, 約 20 種のパルプの色, 繊維素含量, 樹脂含量, 銅價, 粘度, 膨化度, アルカリ吸收度等を比较し, パルプの選定法に就て 論ぜり。中島正, 根岸道治兩氏(繊工 8,255$)$ 怰市販人絹用パルプと製紙 用パルプとの比較分析を行ひ, 結諭として爾者の化學的性質の相違以前者 が後者よりる僅かに多量なる $\alpha$ 繊維素を含有する點にありとし,粘度の相

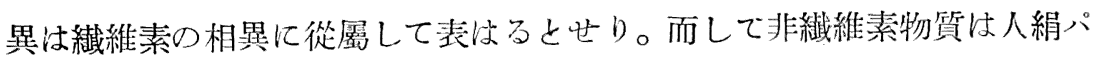
ルプよりる製紙パルプに於て少なきを示せり。中島正, 中原久男兩氏（㵶 工 8, 259) はパルプ中の少量の不純分がそれより作れる㵶維素誘導體に 如何なる影響を與ふるか在知る目的にて醋酸瀻維素の製造を行ひ，不純分 の醋化反應に對する影響はパルプをアルカリ煮沸, 漂白及び叨解に附して 除き得とせり。中島正, 西澤篤志兩氏(㵶工 8，263)は桑皮よりパルプ製造 の賽驗を行ひ菏性曹涬法により純度高きパルプを得られ，此のパルプは織 維素エステル原料汇適すをせり。中村一元氏(繊工 8, 266)はホ木材パルプ の精製法を研究しパルプをクロリネーションに附し, 其原液に苛性源加せ し藥液にて蒸募せるものは漂白容易にして 0 繊維素合量大なりとせり。

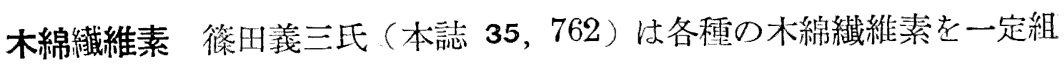
成の銅アムモ二ア溶液に溶解して溶解度を測定し, 又各纎維素の $50 \%$ を 溶解せしむるに必要なる銅初濃度を測定し, 其等の結果よりして纎維素つ 銅アムモニア溶液に於ける溶解性により繊維としての價值を沈定し得べし とせり。良好なる繊維は溶解性低く不良なる繊維に溶解性大なり。

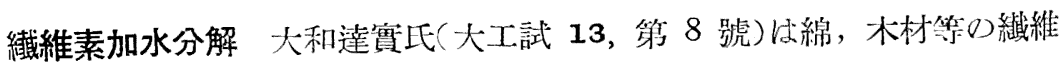
素を高濃度監酸にて品水分解する條件を決定し, 例一ば綿の場合には $15^{\circ} \mathrm{C}$ にて 48 時間にて原試料の 102〜106\%, 又材材場合には $15^{2} \mathrm{C}$ に 24 時間にて原試料の 54 ～ $56 \%$ の得率在得らる 事走示し，倘糖化物の分析 並に其の醴醭試驗老行一り。 
繊維素のアルカリによる膨脹 齋藤義一, 高橋操兩氏 本誌 35, 811)は ラミー, 銅式人絹, ヴィスコース絹綵等のアルカリによる膨脹を實驗し, 長 さと斷面との膨脹より單纎維の容積膨脹を求内, 人絹のアルカリによる膨 化現象を諭ば, 少銅式人絹はヴィスコース絹絲に比し斷面膨脹度著しく大 なるを認めたり。

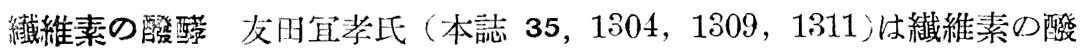

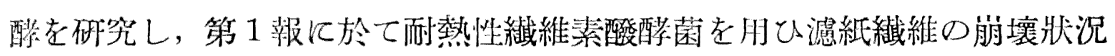

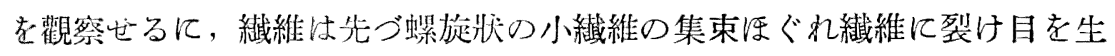

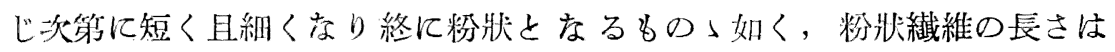
$0.5 \mathrm{~mm}$ 以下の为の多く, 崩壤せる繊維の切斷面は長軸江對し約 $30^{\circ}$ の傾 斜を有せり。種々の纎維質の瞪酵を比较せるに, 滤紙, 薄葉紙, 脫脂綿, 青梅綿は酸醏最も容易にしてヴィスコース絹絲, 亞硫酸パルプ, 新聞紙等々

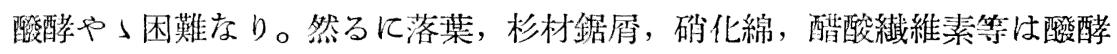

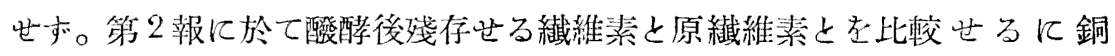

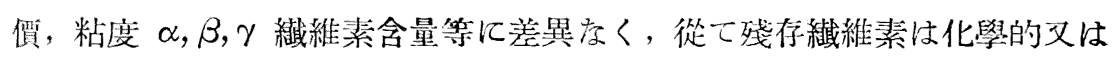
コロイド的變化を受け居らざる事圭認的たり。但し醴酵せる部分は直に分 解し最後凹產物となりて消失し, 殘存繊維素中には分解階梯にある中間生

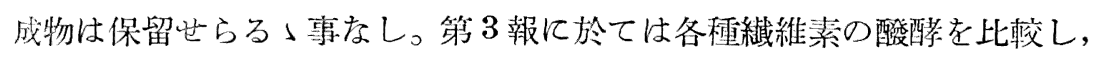
酸酯に對する抵抗性は瀻維の顯微鏡的組織にあるを認めたり。

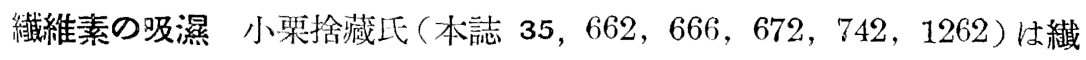
維素の吸濕に就て研究し, 第 5 報に於て繊維素試料の乾燥法として加熱 法, 県空五酸化燐法及び県空法を比較し, 県空五酸化燐法最も有效にして

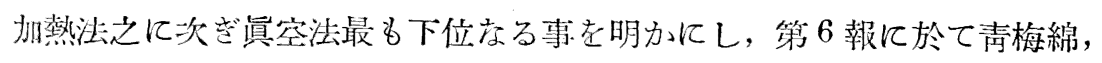

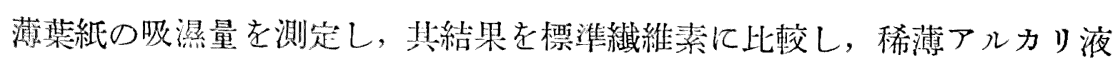

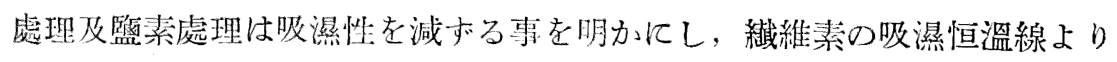


献を補队法によりて求めクラウジウス・クラッペーロン式より吸濕熱を計 算し, 吸濕熱は瀻維素の含水分に殆ど影響を受けざるが如く, 且水蒸氣の 凝縮熱に略等しき事走明かにせり。第 7 報に於ては竹材瀻維の吸濕を研笢 し, 其價は青梅綿より大にして標準綿を $30^{\circ}$ Bé 装性曹達液にて處理せる

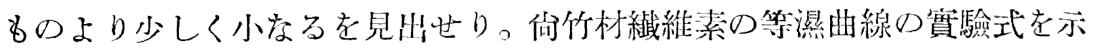
せり。第9 報に於て忖絹絲及羊毛の吸濕老研㠰し吸㶅曲線の實驗式索計算 し, 更に吸濕熱を計算せり。第 10 報に於ては吸濕速度老研究し, 纎維素 の吸濕進行中には吸濕に基づく物理的變化の結界として吸着界面の貹加圭 件ひ更に吸濕を促進するを見たり。而して恒壓下に於ける吸濕速度は $d x$ $d t=K\left(x_{\infty}-x\right)$ により表はさる。但し $x_{\infty}$ は本衡に達したる時の吸濕量に して $x$ は $t$ 時閒に行はれし吸濕量なり。從て吸濕速度は $K^{\prime}=0.4342 K=$ $1 / t \log x_{\infty} / x_{\infty}-x$ にて表はさる。炏に第 8 派に於ては酸化銅アムモニア溶 液より再生せる苦竹及綿纎維素, 並に再生繊維素たるヴ,スコース絹絲の 吸濕量を测定し，起源を異にする繊維素字生繊維素となす時汶同一の吸 濕量を示し, 又再生繊維素はフィルム狀としても繊維状としても队部的吸 着面に汢變化無く, 繊維素吸濕性の大小汢 micell bond の飽和度に係は る事を示せり。

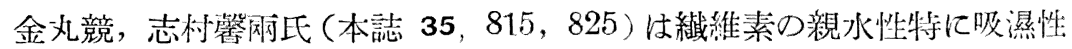
を研究せり。繊維素を乾熱處理に附なると, 化學變化の起らざる限り吸缹 性は低下する事, 繊維素を濕熱處理に附すると吸濕性を增加する事等, 稞々 の熱處理により吸濕性が如何に變化するかを研垫し, 次に加熱處理に上り 㵶維素の水に對すると一電位は增大すれども加熱條件によりて相異ある事 を示し, 更にと一電位はミセル表面に於ける纎維分子の 殘有親和力による 親水性を銃敏に表示する事を述べたり。 
以繊維素の各種有機化合物蒸氣を吸着する現象を實驗し, 其結果を熱力學 的に考究し, 吸着は蒸氣敀, 表面張力, 比重等に上り決定せらる」事老述 べたり。

繊維素の粘度 中岛正, 根岸道治兩氏(本誌 35，1029，1034) は瀻維素 の酸化銅アムモ二ア溶液の比粘度減少は $d \eta / d T=K(\eta-a)$ 飞從ふ事を述 べたり。但し $\eta$ は粘度, $T$ は熟成時間, $a$ は $T=\infty$ の時の $\eta$ なりとす。 又同氏は繊維素濃度と粘度との關係は Baker 氏の式に從ふ事を示せり。 中島正, 五月女清一郎兩氏(本誌 35，1115) は繊維素キサントゲン酸をヴィ スコース熟成副反雇物を含む溶媒に溶解し落球法にて粘度を测定し, 比粘 度 $t$ は $\log t-\log t_{o}=K \cdot C$ てて表はさるっとせり。但し $t_{o}$ は恒數, $C$ は 濃度, $K$ 核濃度恒數なり。侣 $K$ の增加はコロイド粒子の容皘の增加を示 し，即ち $\mathrm{Na}_{2} \mathrm{CS}_{3}$ 及 $\mathrm{Na}_{2} \mathrm{CO}_{3}$ の增加老示す。ヴィスコース熟成中の粘度の 垍大は組織生成以外に溶媒組成の變化による水和度の增加による事を認め たり。

橨田一郎氏(本誌 35，1103) はアインスタイン粘度式より出發し，アル ヘニウス, マルク, フィケンチェル, ベーカー等の粘度, 竖度關係式の相互 關係老明かにし, 次に或コロイド溶液の充分稀薄なるものに於て其溶液の 呈すると同一粘度を同一濃度, 同一測定條件下に於て與へるにはアインス タインの假定に從ひ球形のコロイド粒子ならば其の $1 \mathrm{~g}$ の物質が幾何の容 樍 ce を占むべきかの價を比較するを便とすとし, 此價をコロイドの比容 積と稱せり。次に同氏(本誌 35, 1110，は繊維素エステル, ゴム等の溶液 のコロイド粒子の比容積を算出し, 次にベーカーの粘度式を用ひ所謂分子 量を計算し得る事を示せり。

向繊維素の粘度に關しては, 櫻田一郎氏（本誌 35, 192）は厚木氏等の

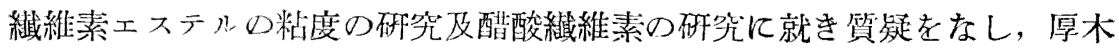


勝基, 石原昌訓, 石井道一郎氏等、本誌 35, 192 )之に答へ, 更に櫻田一郎 氏本誌 35，1098）は再質是をなし，厚不勝基，石原昌訓网氏（本誌 35, 1098，之に答へたり。

繊維素の酸化銅アムモニア溶液 石井直次郎氏(本誌 35, 178, 183,186) は第 1,2 文3報に於て酸化銅アムモニアの酸化接觸作用を研究せり。同溶液

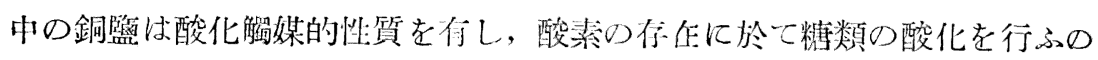
みはら挑續てアムモニアを酸化し亞硝酸を生成し, 亞确酸の生成反應は真 空に於ては 2 分子反應でするが酸素㷛制限に你在する時㳉 $\mathrm{X}=A\left(1-e^{-K t}\right)$ により反應は進异。Xは亞硝酸生成量, $t$ は反應開始上门の時間, $K$ は反 應速度恒數 $A$ に存在する銅の $\mathrm{mol}$ 政に一致する。而して酸化は $2 \mathrm{NH}_{4} \mathrm{OH}$ $+3 \mathrm{O}_{2}=\mathrm{NO} \cdot \mathrm{HO}+4 \mathrm{H}_{2} \mathrm{O}$ にて表はされ，亞硝酸は銅との化合比 $1: 1$ な る複監的化合物を作る。次酸素の作用の下に於ける酸化銅アムモニア中 の纎維素の崩壞分散は不活性瓦斯中に於けるよりる著し。繊維素を結合せ る銅錯監は亞硝酸と絬合せる場合と同樣酸化接觸能を侍せず。次で第 3 報 に於て酸化銅アムモ 光及酸素と遮斷して保存する時, 粘度 $\eta_{s}$ と時間 $t$ との關係は $\eta_{s}=A+$ $B e^{-K t}$ にて表はされ， $(A+B)$ を以て評價すべきを主張せり。次に石井直 次郎氏（纎工 8,44）致酸化銅アムモ を測定し，反應速度は熱量的に測定せる結啉 $K=\frac{1}{(a-b) \sqrt{ } t} \ln \frac{(a-x) b}{(b-x) a} に て$ 示さるとせり。但し $a$ は反應に與る繊維素のモ几数， $b$ は繊維素に對す る銅錯鹽の $g$ 當量, $x$ は反應時間 $t$ 內 反反應せる物能の $g$ 當量なり。

纎維素エステルの膨潤溶解性 櫻田一郎氏(本誌 35, 1246) はアセトン

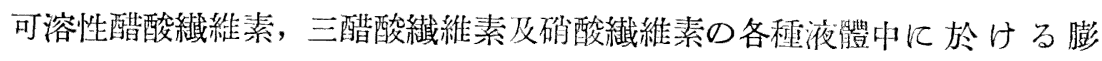
潤溶解性を論じ，乙等は同樣に極性の弱い液體に於けるよりも極性の强い 液體に於てょく膨㵎溶解し, 分子容積は小なる程, 分子會合度は低き程, 
膨潤溶解飞 好都合なる事, 又雙梆子能率/分子容耫の數值が 其の液體の是

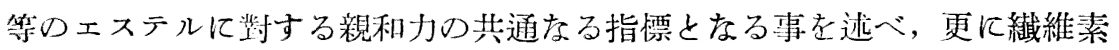
母體の崩壇程度及酸含有率が溶解性に影響を有する事を述べたり。

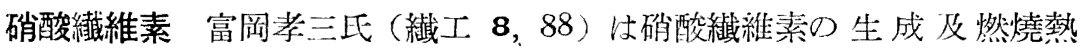
量を測定し, 生成熱量は 1\% 穿素量の差飞對し $75 \mathrm{geal}_{15} / \mathrm{g}$ の差を生じ, $\mathrm{N}_{-}=7.66 \%$ のもの㳉 $958.9 \mathrm{~g} \quad \mathrm{eal}_{15} / \mathrm{g}, \mathrm{N}_{2}=13.58 \%$ のものは $518.7 \mathrm{gcal}_{15} / \mathrm{g}$

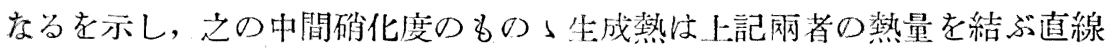
上江西る老知り, 又燃燒熱は $\mathrm{N}_{2}=7.66 \%$ ○为の $3071 \mathrm{gcal}_{15} / \mathrm{g}, \mathrm{N}:=13.58 \%$ のもの $2286 \mathrm{gcal}_{5} / \mathrm{g}$ にして中間硝化度のもの子燃燒熱は上記兩者の燃燒熱 量在結ぶ直線上沉西りて $\mathrm{N}_{2}$ の量 $1 \%$ 亿對する燃燒熱の差は $135 \mathrm{gcal}_{15} / \mathrm{g}$ 放る老決定世り。

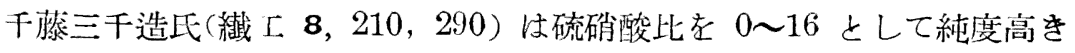
透明なる硝化酸 122 種を作り, 特別精製の衡綿を $20^{\circ} \mathrm{C}$ の酸にて硝化し,

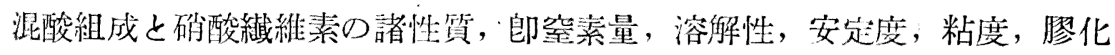
度, 凝固劑用量等との關係を實驗し, 其絬果上して硝化均一度に大差なく

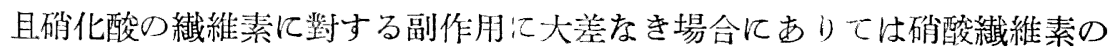
主要性質は大體窟素量に從て變化するものと認めたり。然れども硝化酸の

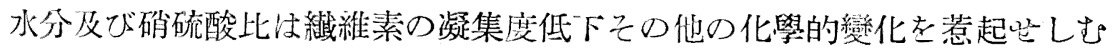
る故に之に依て确酸繊維素の性質は多少の變化を示すことを認めてり。次

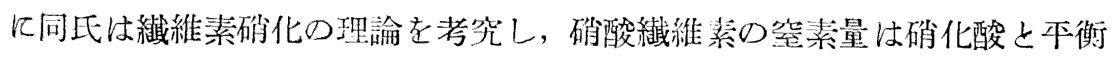

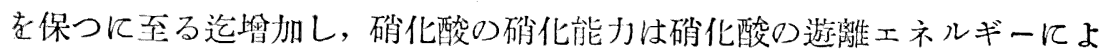
るものなりとし, 硝酸 1 モルを含付する硝化酸の遊離エネルギー Fnを $\mathrm{F} n=\frac{R T}{x} \int_{0}^{x} \ln \frac{P n}{P} d x$ の式上り算出し, 之老以て硝化酸の㗂化能力を考察せ 日。(但し $P n$ 以純硝酸の蒸氭壓 $(T), x$ は液溶相の成分の分子率比とす。 混酸中の硫酸の作用は硝酸上り水分を除去し, 硝酸蒸氣堐の低下を防ぎ以 
て混酸の遊離エネルギーを高め, 混酸の确化力を增さしむると共に硝化に よりて生ずる水を固定し, 混酸の遊離エネルギーの低下師ち硝化能力の減 退を防ぐ外, 混酸の繊維膨潤を助け硝化を均一に行はしさるにありとせり。

友成九十九氏(本誌 35，1145) は窒素含有量同一なる硝酸纎維素を混合 溶劑に溶昭しプルフリッヒ属折計在月ひ属折率老测定する時は确酸纎維素 の製造條件及び後處理によりて著しき相異を示す事苗を研管し，此の相異 は确酸繊維素中に存在し安定處理によりて除去し得る不安定不純分の存在 に原因する事を確め, 從て硝酸纎維素の混合溶劑の屈析率と其の安定性と の間には直接の關係ある事を知れり。從て屈折率によりて安定性を測るを 得, 又屈折率によりて硝酸纎維素の精製法を管理し得べしとせり。櫻田一 郎, 谷口政勝网氏(本誌 35,692 ) はベンジール・アセトン及ベンジール醋 酸メチ儿等の 2 成分系は普通の硝化纎維素試料に對し任意の溶解力を有寸 る溶劑を取り得る事, 數種の硝化繊維素の溶解度曲線を比較し, 硝化紙仗 加熱加壓する事により纎維の崩壞に件ひ溶解し易くなると共に硝酸基の脫 出により溶解し難くなる事, ベンゾール・醋酸メチル, ベンゾール・ア七ト ン采に於て溶劑の同一溶解力在有寸る點に於ては其の溶劑中の侍極性物質 の双極子能率と其の相當する組成のモ儿濃度との相乘積は略一定なる事, ベンゾールを一成分とし他の任意の液繥を第二成分として或試料に就き上 と同样の溶解度曲線を作ればとに依りて足量的に各液體の溶解力止比较し 得る事等老報告せり。榴田一郎, 庄司野正雄兩氏（本誌 35, 751）は醋酸

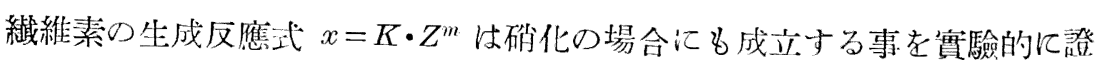
明せり。

厚木勝基, 石原昌訓兩氏(本誌 35, 1453) は硝化に於て三硝酸瀻維素 $(\mathrm{N}$ =14.14\%）に相當する最高确酸繊維素を得られざる原因を追㠰し, 其原因 は緎維に滲透する确化酸が稀薄よなり，此組成にて平衡に澾するにある事 
を認めをり。

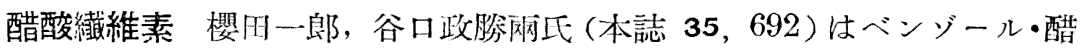
酸メチル, 四監化炭素・醋酸メチル, ベンジール・アセトン等の 2 成分系を 用し，其組成を變更し任意の溶解力を有する溶劑を作り，乙によりてアセ トン可溶州醋酸纎維素の分别溶解老行へり，之に上りて試料の均一性及び 溶劑の溶解力老测り得らる。佮溶解分の醋酸含有量は同一にしてアセトン 溶液の粘度は溶解し易きもの程低きを認めたり。櫻田一郎氏、本誌 35 , 377 ）は繊維素瀻維を其外形を失はしめずにェステル化又はェーテル化す 万場合汇反應速度は $x=K Z^{m}$ にて示さる」事を醋酸化其他の實驗結果よ り證明せり。但し $x$ は $\mathrm{C}_{6} 100$ モルに結合桨る醋酸モル數， $Z$ は時間にし て $K, Z$ は恒數なり, 此の研㠰範圍にては $m=0.215 \sim 0.530, K=3.1 \sim 16.3$ なり。次に櫻田一鄐氏(本誌 35,746 )は前報に得たる反應速度式は瀻維を 獯水醋酸にて加熱して醋化する場合其の反應が圓滑に進めば醋化中一部試 料以溶解するに係はら亦成立する事を證し, 更に瀻維を無水醋酸, 水醋酸 及び硫酸にて醋化する場合, 繊維の表面のェステル化せる部分より溶解し 行く上すれ溶解速度は $d x / d z=K(a-x)^{3}$ にて示さるとせり。但し $d x / d z$ は溶解速度, $x$ は或時間迄に溶解せる量, $a$ は最初の試料の量, $\dot{K}$ は恒數 友り。

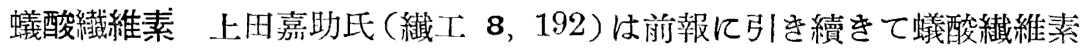
生成に對する溫度と時間との影響を研究し,再生瀻維素 $2 \mathrm{~g}$ に對し HCOOH $20 \mathrm{~g}, \mathrm{H}_{2} \mathrm{SO}_{4}(1.84) 1.5 \mathrm{~g}$ を使用し, 溫度 15 及 $20^{\circ} \mathrm{C}$ にて種々の時間エ ステル化し，其の生戌物を分析し生成せる蟻酸纎維素はモノフォーメート $(\mathrm{H} \cdot \mathrm{COOH}=24.21 \%)$ に近きを示やり。

繊維素キサントゲン酸曹達 櫻田一郎, 井上亮本兩氏(本誌 35, 383)は アルカリ䊼維素生成の際のアルカリ濃度，アルカリ纎維素の硫化時間等を 
變更し，繊維素キサントゲン酸曹達の溶解性及びキサントゲン化度を分析 決定し, キサントゲン酸化の進行と溶解性の增加とは平行せざる事, 不溶 解分と溶解分とのキサントゲン酸化度な大差なき事等老認め, 佔アルカリ

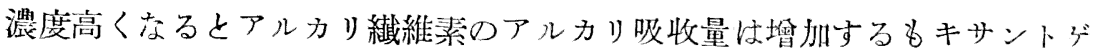
ン酸化茫は低下する事等の事實を見出せり。

ヴィスコース 岩崎振一郎, 杉野篓二兩氏(本誌 35, 313 )はアルカリ瀻 維素老成時に於ける纎維素粒子の崩壞に就て研究せり。種及の期間老成せ しめたるアルカリ纖維素を試料とし, 其のヴィスコースの粘度, 再生繊維素 の銅アムモニア液粘度を测定し，アルカリ繊維素老成中に纎維素粒子の大 さは幾分減少するが其の程度は著しからざるを認め, 丈老成它るものはヴィ スコースの溶解容易にして熟成中の粘度變化少なき事老認め炡り。次に同 氏(本誌 35，318)はアルカリ繊維素の加硫速度に就て研究し, 加硫時間と 結合ナトリウム及び結合硫黄との對数曲線を求出, 其結果に上りて硫化の 最初に生ずるものは $\left(\mathrm{C}_{12}\right.$ - $\mathrm{CS}_{2} \cdot \mathrm{Na}$ に相當するものたるを詠し, 更に硫化 を續する時は硫化度高きキサントゲン酸ナトリウムを坐柿るとせり。次に 岩崎振一郎, 杉野榮二兩氏(本誌 35,586壮スピ)メ一タ一を應用し, ア ルカリ繊維素の老成がヴィスコースの可紡性に如何に影響するか天之が紡 浴組成により如何に變化するか文其等が老成のメヂウム行より如何に影響 せらる」かを見をり、岩崎振一郎, 杉野策二网氏(本誌 35,679 ) はヴィス コースの粘度に就て研究し, 老成操作を省略し, チォ硫酸監等を涯加する 事により粘度を低下し得るや否や, 又之等の涯加により老成期間の短縮及 び文による㵶維素劣化心包避をなし得るや否や等つ實驗を行へり。更に岩 崎振一郎，杉野榮二兩氏（本誌 35，872）はヴィスコースの構浩粘度に就て 研究しヴィスコースの流出量 $v$ と㕍力 $p$ との間には $v=K p^{n}$ の關係が成 立し， $n$ はアルカリ纎維素の老成及びヴィスコースの熟成に依て變化する 
を見たり。更に落球卡粘度計に於て構成粘度か球の大さにより如何に影響 㤁らるつかを試驗せり。

中島正氏(本誌 35，867) はヴィスコースの纎維素濃度 $C$ と比粘度 $\eta$ と の間には浱度 $5 \sim 10 \mathrm{~g} / 100 \mathrm{ec}$ の範園にては $\log \eta=\log t / t_{0}=K_{c} \cdot C$ の關係あ るを示世り。但し $t$ は港度 $C$ の時の球の落下時間, $t_{0}$ は恒數, $K_{c}$ は濃 度と然關係にて熟成により異る恒數なり。而して熟成日數を $D$ とすれ代 $\left.K_{c}=a+b^{\prime} D-d\right)$ の關係㐫り。 $a$ は比粘度最低時の $K_{c}, d$ は比粘度最低 になるまでの老成日數, $b$ 恒數なり。更にアルカリ緎維素老成日數 $A$ と粘度との間には $\eta \bullet A_{n}=K_{A}$ の關係击り。而して $K_{A}=p+q(D-d) \circlearrowright$ 關係亦り。但し $p$ は比粘度最低時の $K_{\alpha}$ なり。

岩崎振一郎, 杉野榮二兩氏 (本誌 35, 1378) は再びスピ)メータ一及其 應用に就て研究し, 老成程度及均一性を異にするアルカリ繊維素上り造れ るヴィスコースの可紡性の熟成による變化をスピノメーターに上り測定し， 葡葢糖を含む紡浴では均一性ヴィスコースに比し，不均一性ヴィスコース は可紡度高く且熟成後期に於ても可紡度高く, $\mathrm{ZnSO}_{4}$ 名含む紡浴にては其 差稍少く, $\mathrm{H}_{2} \mathrm{SO}_{4}$ 紡浴にては一般に可紡度低く老成程度及均一不均一性 に上る差異少なき等の事實を認め, 佾ホっランルート曲線, ヴィスコース調 製處方操作等に就て諭ぜり。

杉田辰男氏（纎工 8，3）はヴィスコースの隔膜平衡を研笕し，隔膜平衡 り成立を確登し，纎維素キサントゲン酸曹達が分散媒中にてイオン解離せ る事を明かにし，イオン解離說よりヴィスコース熟成中の變化を推考せり 次に杉田辰男氏・(繊工 8，166）はヴィスコースを豚の膀胱を牛透膜として 清水に對し透析し, 遊離アルカリの減少とヴィスコースの精製度とを比較 し, 且遊離アルカリが完全に除去せらる」以前よりヴィスコースの加水分 解起り, 結合アルカリの滆减する等の現象を示せり。厚木朌基, 祖父江寬 
兩氏(纎工 8，70) はヴィスコースのシネリシスを研究し，シネリシスと別 個にヴィスコースの自然分解が行はれ，之が疑固及びシネリシスの不可逆 性の原因をなすとせり。

ヴィスコースの紡絲 長谷信一郎氏は第 1～11 報(本誌 35，625，629， $636,728,737,887,890,970,976,1124,1129)$ に於てヴィスコ一スの 紡綵に關する研究を發表せり。第 1 報に於てボビン式紡絲法により $\mathrm{H}_{2} \mathrm{SO}_{4}$, $\mathrm{MgSO}_{4}, \mathrm{Na}_{2} \mathrm{SO}_{4}, \mathrm{ZnSO}_{4}$ を含有する凝固浴を用ひ溫湯老第 2 浴としてヴィ スコース老紡絲し, 水洗乾燥後綵に生市る乳白色は凝固不完全に原因して 生和る事を明かにし，第 2 報に於て凝固不完全なる絲の性質を試驗し， 第3 報に於て凝固不完全なる緤の生亦る原因は凝固浴の溫度, 循環, 深さ 等の不齊にありとし，之が匡正法を論ぜり。第 4 及 5 報に於ては各種の

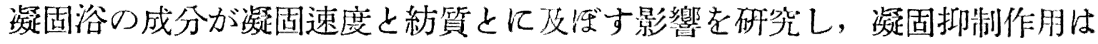
$\mathrm{ZnSO}_{4}$, 葡萄糖, $\mathrm{Na}_{2} \mathrm{SO}_{4}, \mathrm{MgSO}_{4}$ の順序にて小となる事, 又硫酸監の凝 固抑制作用は $\mathrm{Mg}<\mathrm{Na}<\mathrm{NH}_{4}<\mathrm{Fe}<\mathrm{Zn}$ なる事, $\mathrm{ZnSO}_{4}$ は絲の手觸りを硬 化し $\mathrm{MgSO}_{4}$ は之を軟化する事, 其他ボビン式紡線の操業法に就て報告せ り。第 6 報に於ては綵の斷面の性質を示す䨗に $\lambda=L / L^{\prime}$ なる係數を用ひ るべをを提架せり。但し $L=$ 斷面の周圍の長， $L^{\prime}=A$ と同一面積の圓の周 圍の長， $A$ 注斷面積にして， $\lambda=0.282 \times L \sqrt{A}$ なり。而して $\lambda$ は $\mathrm{ZnSO}_{4}$ 浴にて怡凝固速度の小なる程大となり， $\mathrm{MgSO}_{4}$ 浴又は $\mathrm{MgSO}_{4}+\mathrm{Na}_{2} \mathrm{SO}_{4}$ 浴にては $\mathrm{MgSO}_{4}$ 量大なる程大となる。硫酸虎の入に及代す影響は $\mathrm{NH}_{4}<$ $\mathrm{Na}<\mathrm{Mg}<\mathrm{Zn}$ なり。第 7 報に於ては㠜固浴の組成が直接染料吸着性に及代 す影響を研究し, $\mathrm{H}_{2} \mathrm{SO}_{4}$ 量を一定とぜる場合に $\mathrm{Na}_{2} \mathrm{SO}_{4}, \mathrm{MgSO}_{4},\left(\mathrm{NH}_{4}\right)_{2} \mathrm{SO}_{4}$ の添加量の大なるに從て吸收度㳊減少すれど $\mathrm{ZnSO}_{4}$ にはか子る影響なし とせり。第 8 報に於てはヴィスコースの凝固反應速度はヴィスコース熟成 度大なる程, 硫酸濃度を大とする程, 單絲數を增加する程大となる事を示 
せり。第 9 報に於てはケーク熟成中の變化を論じ, 第 10 報にてはヴィス コース紐流に接觸する凝固浴組成の變化, 第 11 報にては凝固反應考考究 せり。ヴィスコース細流が凝固浴に流出するや, $\mathrm{H}_{2} \mathrm{SO}_{4}$ の中和, 硫酸監の 撗散等により䐒水せられ容積在收縮し, 凝膠體上なり, 其表面放硬化し, 硬化層は內部に擴大し, 外窑屿分解し繊維素を再生すとせり。

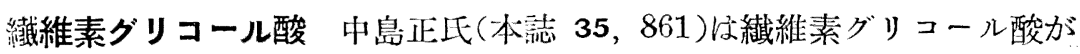

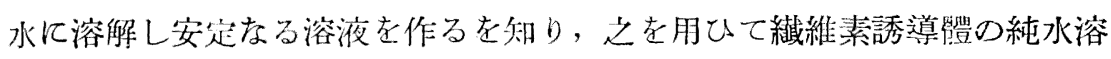
液の粘度を研究し，その電解質に對する影響を研究し，次に其結果を應用 してヴィスコース熟成中の粘度變化の原因の說明を試みたり。

ベンジル瀻維素 荒不鶴雄, 長表貞二.网氏(本誌 35, 167 ; 臅逸 I. G 染料會社のベンジル纎維素の溶解性, 皮膜形成性, 旸布塗料としこの適否 等を研究せり。

ヴィコース絹絲 河田善太郎氏繊工 8，21)はヴィスコース綟絲の脫硫 を研究し, $\mathrm{Na}_{2} \mathrm{~S}$ 渗液に葡䓈糖其他を涯加せる脫硫影響を試驗し $\mathrm{Na}_{9} \mathrm{SO}_{3}$ 溶液の脫硫は反應や〉少るも絲質を害せず， $\mathrm{NaOH}$ 溶液の脫硫は硫黃少 なき絲に適するも絲質を損傷する恐ありとせり。而して夫火の場合の脫硫 條件を考究せり。又同氏(繊工 8,94) はヴィスコース絲の染着性は纎維素 がアルカリの作用を强く受けたる時に良好にして酸の作用を强く受けたる 時に不良となるとし又セントル式紡絲の絲はボビン式紡絲の絲より染着性 よく引伸, 高速度紡絲の絲, 小デニールの絲は染着性惡しきを認めをり。更 に同氏（纎工 8，48）は脫硫溶液の分析在考究し沃度法, 硫酸亞鉛法, 硝 酸銀法を比較し, 之等は多硫化物に對し一硫化物の如く反應すとし脫硫反 應は $\mathrm{Na}_{2} \mathrm{~S}$ が $\mathrm{Na}_{2} \mathrm{Sx}$ 老作る外に $\mathrm{Na}_{2} \mathrm{~S}_{2} \mathrm{O}_{3}$ 其他の $\mathrm{S}$ 化合物を作るものと せり。次に同氏 (本誌 35，637）は款原式セリグラフを使用し種くなる人 造絹綵の强伸度曲線圖を作り酸, 監, アルカリが絲に附着せる場合に絲の 
强力伸度の害せらるつ爿況を實驗的に示し, 更に强伸度胜線つ示す仕事量 は测定時の溫度, 濕度に影響なき事, デニール仕事量及び比仕事量の大な る絲は優良なる事等を述べサり。

紙 青野武雄氏(本誌 35，1093) は包裝用紙の防濕力在測定する簡易に して比較的精確なる测定器考考案製作し, 之を使用して各種包裝紙に防濕 力を比較せり。測定器は一定裝犆內に取り付けたる檢紙の下面に空氣又は 一䇥瓦斯を揆り, 紙を壓力により上方に壓し, マノメーターの水銀頭が一 定目盛動く時間を測定するものなり。

絹フィブロイン 福島郁三, 高松勇次郎网氏(本誌 35, 20) は絹フィブロ インに對する銅アミン液の作用を研究し，兩者の間に於て[Fibroin $\mathrm{Cu}$ ] $\left[\mathrm{Cu}(\mathrm{En})_{2}\right] ; \mathrm{En}_{\mathrm{n}}=\mathrm{H}_{2} \mathrm{NCH}_{2} \mathrm{CH}_{2} \mathrm{NH}_{2}$ なる反應物を生じフィブロインは溶解 するとなせり。

セリシン 金子英雄氏（農化 8,1190，1196）はセリシンの水, 監類溶 液, 酸, アルカリ溶液山に於ける膨化を實驗し, 監類溶液に於ける膨化忙 ホフマイステルイテン系列に從ふ事を證し, 又セリシンA は $\mathrm{B}$ 上り水に 於ける膨化性大なれども脂肪酸監中にては小なる事を認め, 份膨化と等電 點, 溫度等の關係を述べたり。次にヒリシン溶液の凍絬を研究し, 一部は 不可逆的凝固をなし一部は可这的凝固をなすを認め, 份凍結の條件及び凍 結の結果考考究せり。

絹精練 角替利策氏（本誌 35，407; 農化 8，330）は石鹵の絹に對寸る

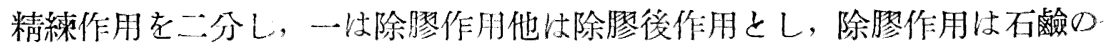

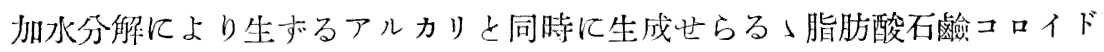
との共同作用なりとし，アルカリはセリシン及フィブロインと化學的結

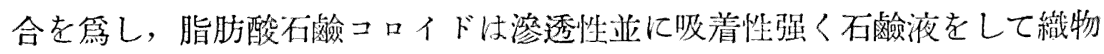
組織の內部に能く滲透し精練它しむ上せり。豐田今吉, 後藤章网岖 (本誌 


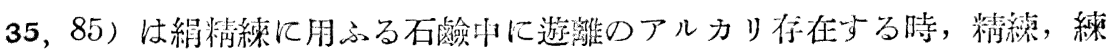

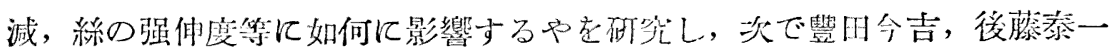

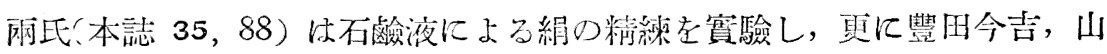

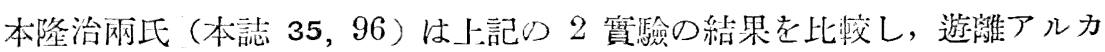
リの作用, 石簽の作用に就て考究せり。

\section{0. 禟類, 澱粉及其他の炭水化物}

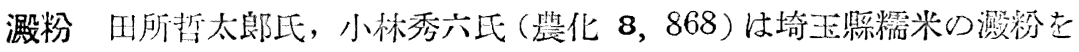
研究し, 水稻, 糯米, 澱粉愉稻の为のに比し粘度高く, 加熱に上る粘度低

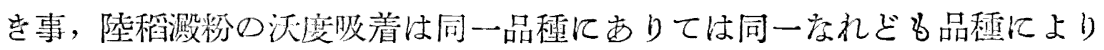
フロインドリッヒ吸着式の指數を異にする事,等稞々の忹質異同を明かにせ り。又田所哲太郎, 吉村克二爾氏（基化 8，944）は各地の水稻及び陸稻糯 米の粘度變化を研究し, 其の買同及び異同の原因を迹べたり。西村資治氏 （農化 8，400）约澱粉も, 之れより分離せるアミロースも，アミロペクチ ンも共にマルツヂアスターゼによる梼化に著しき難易を示さ亦，糖化の經 過も亦略相等しをを認めをり。

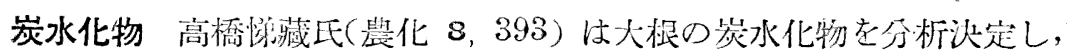

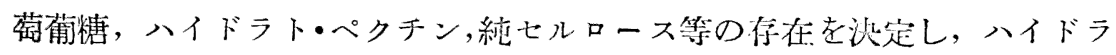
トペクチンよりペクチン酸, ペントザン，ガラクチュロン酸等を分䠰又は 生成せしめ其量索決定世门。

蔗糖檢出 清水正雄, 岩狹與三郎兩氏農化 8, 1280)はフロ、グルシン の䵇糖に對する反應を以て牛乳中の茩糖檢出に應用し，牛乳中にては 0.02 \%, 水中にては $0.001 \%$ 菣糖を檢出し得たり。

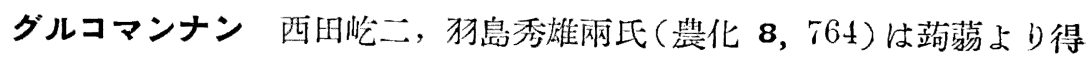
たるグルコマンナンの構透を研究し, 其の根翰は Glukomannotrihexose 
にして，光が酸秦橋にて重合しマンナンを生杪とせり。

\section{1. 醇酵}

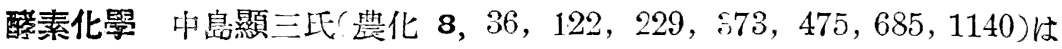

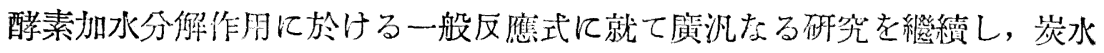
化合物, 蛋白質, 脂肪等の酵素に依る加水分徨の場合に適合する一般式を

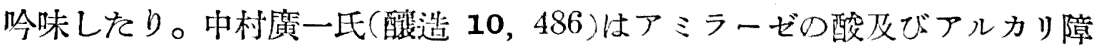

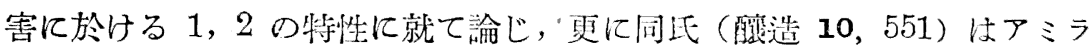
一ゼのアクチバトール及コンプレメントとカルシウムとの閵係を諭じを り。眥川豐作氏はアミロシンテアーゼに關する詳細なる研笲を發表せり。 アミロシンテアーゼは師ち澱粉合成醳素にして西村資治氏の發見にか」る るのなり。該酵素の發見は酵素化學上多大なる寄與をなすものにして，西

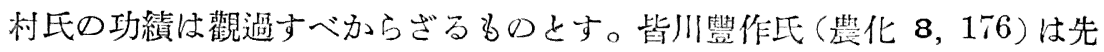
づ西村氏が酵母中に發見せられたる澱粉合成醋索に就て研究を始わ，該酵

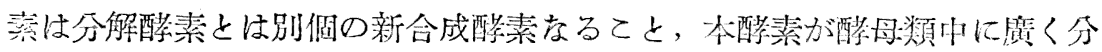

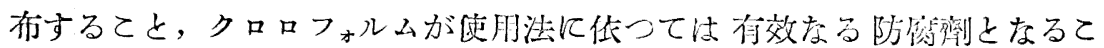
と，本酵素がタカヂアスターゼ ( $\alpha$-酵素) 及び麥手アミラーゼ（ $\beta$-酵素） の分解生成せるデキストリンを同樣に重合するとと, 证に本陼素が澱粉の グリセリン分解物ヘキサヘキソーザンを重合するもトリヘキソーザンを重 合些ざるととを明かにせり。次に同比(器化 8,508) は硫酸アンモニウム を使用して粉末狀の强力洨るアミロシンテアーゼを製出するととに成功 し，アミロシンテアーゼがアルコール，アセトン等に致命的に害せらる」 ことを認的をり。次で同氏（農化 8，510）は馬鈴暮及び玄米より新法に依 りアミロシンテアーゼを分離したり。又同氏(農化 8，811)はアミラーゼ を含まざるアミロシンテアーゼの货出老企て类酒酵母より液化力, 糊精化 
力及び糖化力を付するアミラーゼを分媰し，西村氏の發見せるアミロペク” チナーゼの作用はアミラーゼとアミロシンテアーゼの混合物の作用にして アミロペクチナーゼなるものは筫在せざること，並にアミラーゼを除去せ るアミロシンテアーゼは然らざるものより其の作用著しくなるととを認り たり。又同氏(農化 8，914）はアミラーゼ在除去せるアミロシンテアーゼ はアミロペクチン（澱粉の約 80\%)の單位と帣へらう〉トリヘキソーザン 在重合ナるとと索認为たり。更に同氏（農化 $8 ， 1068$ ）は醋酸鉛に依るア ミラーゼとアミロシンテアーゼとの分離法を企て，アミロシンテアーゼ放 醋酸蛻に依り沈淈し，之を脫鉛する時强力なるアミロシンテアーゼを再生 し得ら礼，此方法に依りアミラーゼと分離するてとを得をり。尚同氏（農 化 8，1310梳アミロシンテアーゼぶ燐酸カルシウム, 燐酸アルミニウム, 水酸化アルミニウム，カオリン，活州菼素等によく吸着せられ，種ぬなる 方法に低りこ再び㜿離せし内得らる」こと, 又吸着後硫酸アンモニウムに

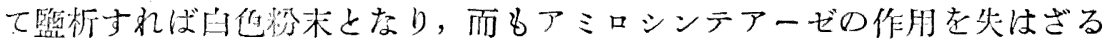
とと，酵母アミラーゼと酵母アミロシンテアーゼとを分别籃析しアミロシ ンテアーゼの作用が非可逆性なるととを確めたり。

试富早, 堀越武雄兩氏（本誌 35，1444）は障害を受けたる数インヴェル

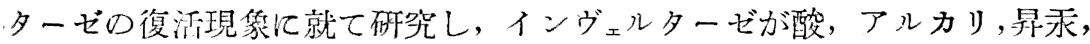
加熱等に依り障害を受けたる後の復活作用在試驗せり。黑野勘六, 勝目英, 大水宏男氏等( 農化 8，82) はトリプトファン分解䣲素に就て研究せり。黑

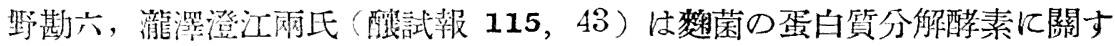
る研究を行ひ，3犁のプロテアーゼの存在在明かに之を分離したり。

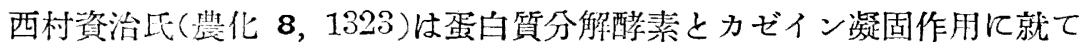
研究し, タカヂアスターゼ，パパイン，パンクレアチン筞に依つて起るカ

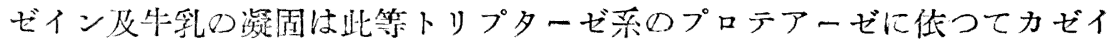


・ンが或程度まで分解されたる時にカルシウムの存在に於て現はる」現象に して特種なるラブ邽素は存在せず, 凝圆は引き續き次第に分解さるつこと を認め，パパインに依るカゼイン及び牛乳の分解と凝固との比は此等トリ プターゼ采のプロテアーゼとは著しく相違し, 凝固作用は分解作用に比し て甚だ大なるが凝闻は一定の條件に於てのみよく現はる」こと虑認め，百 にペプシンに依るカゼイン及オ゙牛乳の分解と凝固に及ぼす溫度，pH，吸 着等の影響は全く相等しく，此等网作肞は侗々の酸素に依つて行はるとは

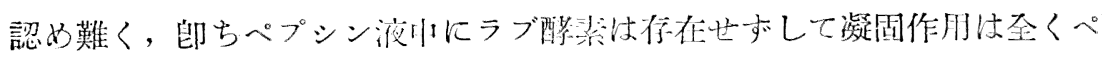

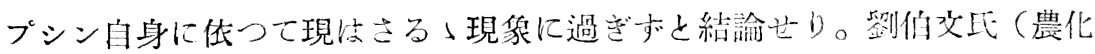
8，273）は微豆腐の酵秦に就て研究せり。

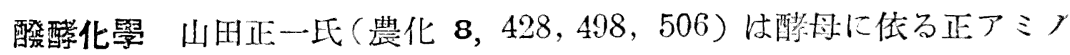
酸の分解に就て研究し,アラニン，2-アミノー正酪酸等の場合を賽驗せり。 高橋偵造, 朝井勇宣兩氏(農化 8，652)はアクチノミヒスに依つ隥酵生产 物に就て研究し, 葡蓗糖より左旋性乳酸及支ア゙アチルメチルカービノルの

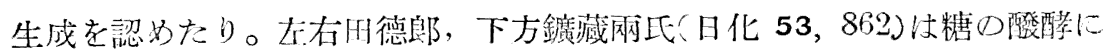
件ふクレアチンのクレアチニンへの曫化に就て研究せり。

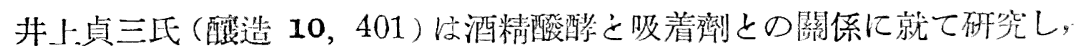
吸着劑複合活性炭素 (Fermentact) 证に珪石微粉末の酒精唒酵促進作用衣

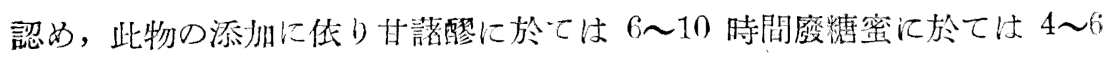
時間醱酵の短縮を在得をり。メアルコール收得率も 0.4 ～ $0.9 \%$ 增加するを 認めたり。

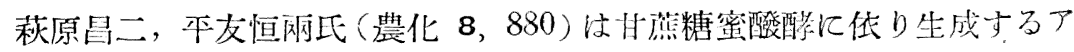

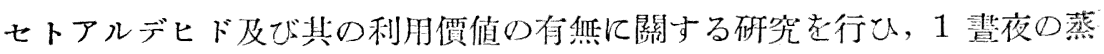
溜能力 $100 l$ の小規模ギョーム式蒸溜機上り生するる初溜と中溜との中にアセ トアルデヒドとアセタルを含有することを決题し, 硫酸ヒドロキシルアミ 
ンを用ひて醴酵慗中のア七トアルデヒドの含何量を测起し, 更にカールス

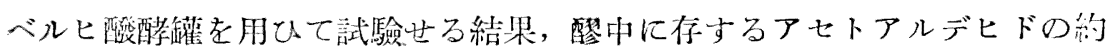

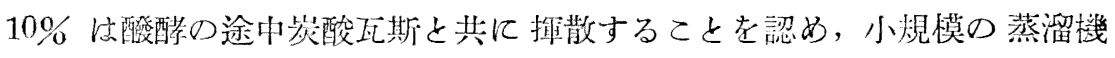
に於てはアルデヒドの大部分は蒸溜の途中にて變化消失するものの如く， 排氣ガスと共に逸散する量証極少く，之を捕集利用するに足らずとな ษ。

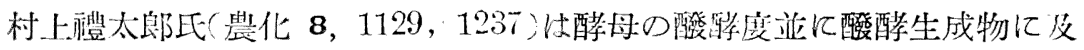
ぼす單色光線の影響に就て研究せり。黑野勘六, 森井義治, 秗林正一氏等

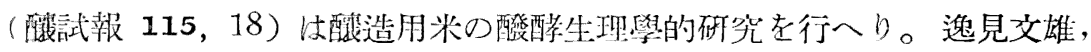

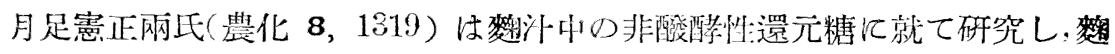
汁中に酒孝母に依り䐉酵せられざる 1 種のへキソース二重糖類の倞在する ことを認め, 加水分解に依りグルコース又はマンノース甤成することを

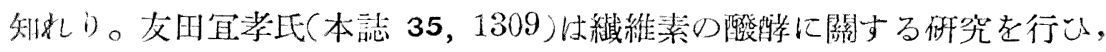

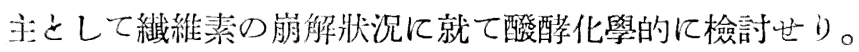

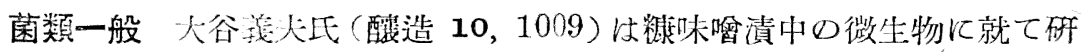

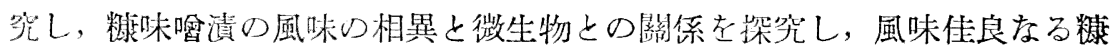
味雷溑中よりは多くの醋母菌, 殊に非產膜酵母の你在多く, 酸味甚だしき \&のに於ては乳酸菌の弡育のみ認めら䄈孝菌の你在を見市, 又少しく酸

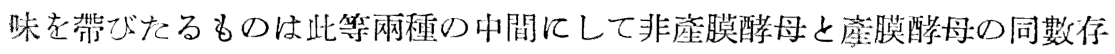
在寸る在認的, 試料中に於ける酵母菌數と乳酸菌數との比を見るに酵母菌 に富さ試料には乳酸菌に乏しく, 乳酸菌に富む試料には酵母菌少く, 此の 兩種菌類の你在は全く相反する關係にあることを報告せり。

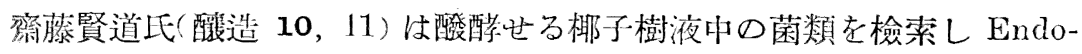
mycopsis Monosporus, Schizosaccharomyces Pombe Lindner, Saccharomycodes Ludwigié Hausen, Zygopichia Chevalieri nov. var. fermanti, 
Pichia Menbranaefaciens Hausen 等老分離せり。大谷義夫氏(䝀造 10, 189）牥梅漬生罡より分離せる酵母菌として Debaryomyces Membranaefaciens nov. var. Zingiheri, Hansenula belgica (Lindner), Sydow w 就て記载せり。

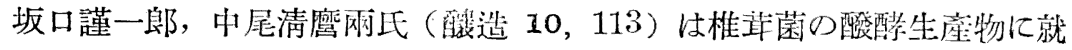

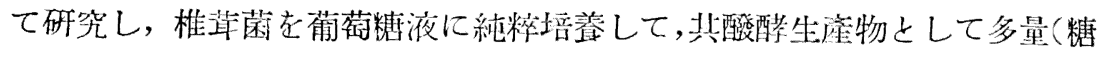
分の $26.21 \%$ ）の鋚酸と少量の還元性有機酸とを得たり。又同氏は才肘干 惟革中にも葆酸の存在を證明し, 其の含有量は $0.195 \%$ にして大部分は水 に可浴性の監として存在するものの如しと言へり。

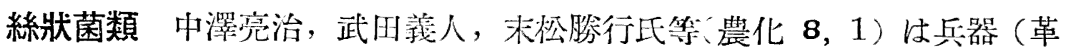
具類, 被覆線及びレンズ）の徽に關する研究を行ひ，皮革及びレンズに附 着繁殖するものの冈 Aspergillus に屬するもの 4 種にして, 内 1 種は既 䊽種, 3 種は新變貔なるを認めたり。即ち Asp. Conicus Blochwitz, Asp. Versicolor Tiraboschi var. fulvus nov. var., Asp. Japonicus Saito var. Capillatus nov. var., Asp. albus Wilchelm var. thermophilus nov. var.これなり。文同氏等は德類が皮革に繁殖したる場合には其の抗張力大 いに減ホること, 硼酸水溶液に皮革を浸漬後取出したるるのは防徽の目的 を達するも硯酸水溶液を塗布したるものは不良をること, 皮革にクロロピ クリン蒸予を作用せしさる時は菌類在死隇せしめ防徽の目的を完全に達し 得らる১こと, 監化亞鉛水溶液 (10\%以上)を塗布したるものは秒及效力 老佮すること, 炭酸ガス中に䟺藏する場合は菌の死滅するもの少きも繁殖 は大んに阻止せらるってと, 手入用脂油類を毛皮に鉒布することは菌の繁 殖を逮延せしむること等索報告せり。

山崎百治氏(鼠造 10，361，475) は綵狀菌類の果糖生產に就て研究し, リゾープス 162-II と焚菌とは明かに累榶を生產するととを認めたり。本 


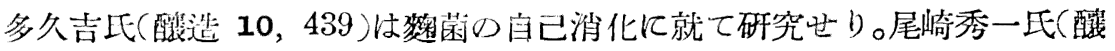

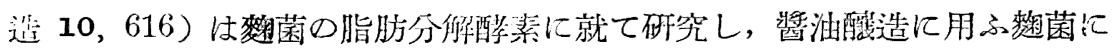

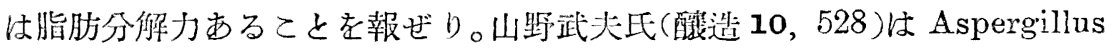
ochraceus の生理に就て研究し其の生產物を報告せり。坂口謹一郎, 中野

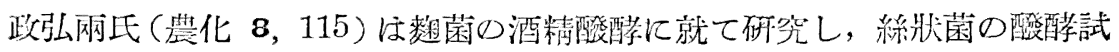

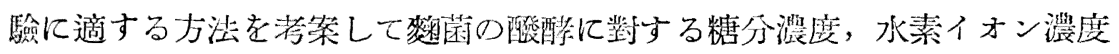
及び溫度の影響圭研究し, 更に枍菌の變㧝 17 種に就て分類上の應用を試

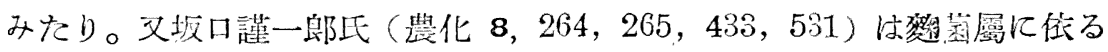

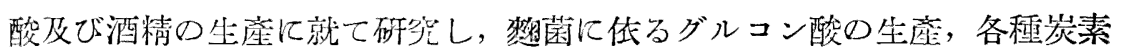
源上り酸の生崖, 猌菌の變種に依る各種酸類の生產に就て研究し,数菌 90 株を用ひて比較生酸試騟を行ひ, 生商されし酸の種類及び其の分量を明か

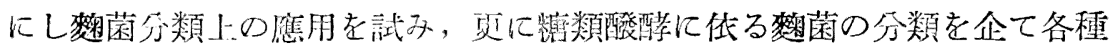

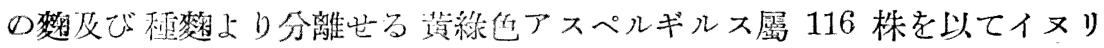
ン,トレハロース, ラフィノース, 乳䌅及びガラクトースに對する酸酤試驗 老行ひて其の酸䣼有無に依りて之老 16 群に分類地り。

山本義彥氏醽造 10，563，638）トリソープス屬に關守研究をなせり。

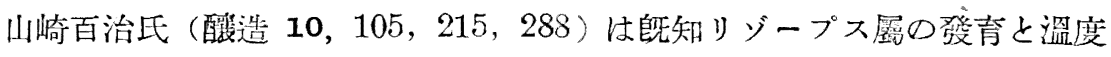

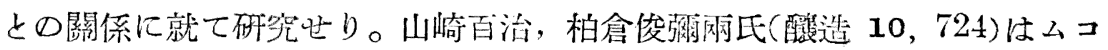

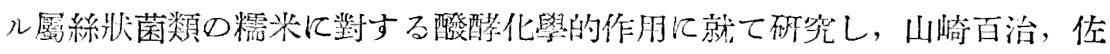

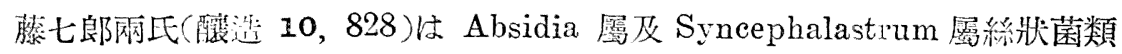
の糯米に對する酸醭化學的作用儿就て研究せり。

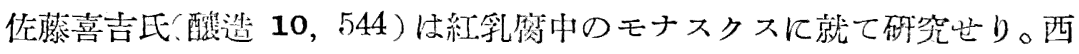
川英治郎氏（農化 8, 1007）は絲狀菌の生化學と題して紅嬏菌（Monase uspurpureus Went) ๑色素流て研究世り。

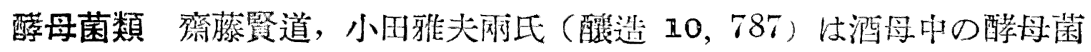




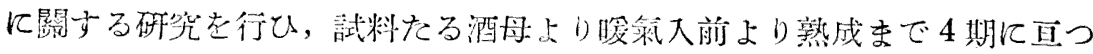
て非座膜性酵母として紅色酵母 2 種, 粘液酵母 1 種, Debaryomyces 1 種 及び其の變型とサッカロミセス㞗 8 型及び其の伹胞子型と見做さるっもの

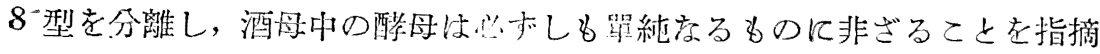

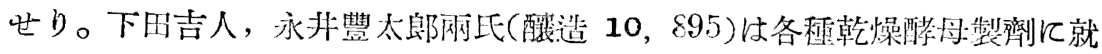
ての比校研笲を行ひ, 其の化學的組成, ヴィタミン B 含有量, 酵母の活

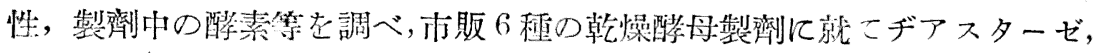
マルターゼ, サッカラーゼ, リパーゼ, プロテアーゼの7酵素老檢出せり。

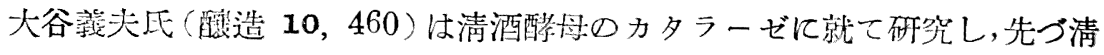
酒酵母のカタラーゼ量の比較及び 2，3 の因よの關係を研究せり。

下平赶夫氏 (農化 8,876) は麥酒酵母の增殖に就て研究し, 各種條件に 對し酵母增殖の良否を比校研究する塕合に, 䤃母收量の多少に依つて決定

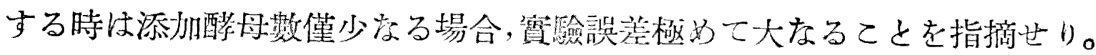
而して移植酵母數䧳少をる場合には極めて正確に同一量を接種する必要あ

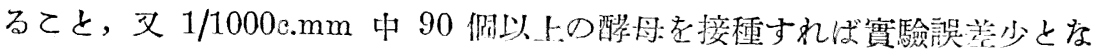
るととを認めたり。份同氏は酵相增殖江最適の糖浱度は Hayduck 氏液の 場合 6７\%，麥芽汁の場合 15～16\% なりとせり。吉村清向，西田孝太郎

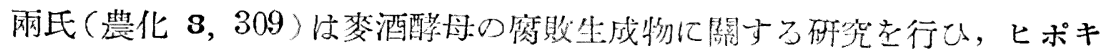
サンチン，プトレシン，チラミン，ヒスタミン、アンモニア,カダベリン, ロイシン等を分離挝り。

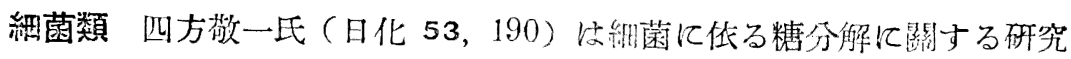
老續行し，瓦斯發生飞就ての定性的觀察を行一り。又四方敬一，頳文男 网氏(日化 53，623)は高溫菌の糖分僻に就て研究监り。山崎何惠氏（農化 8，991，1111)は清酒火落菌類の研完を行ひ，其の生理的性質を調べをり。

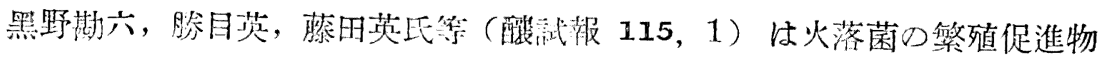


質に就て研究し, 活性岑素 $0.5 \%$ を以て清酒を處理するとをは火落菌の 繁殖を防止し得らる」てとを認め, 活性炭吸着物をピリヂン, 水醋酸等にて 溶出し, 該吸着物の溶出には水素イオン濃度が大いに關與するてとを認め たり。佾同氏等は声酒腐敗促進素として $\mathrm{C}_{10} \mathrm{H}_{16} \mathrm{~N}_{2} \mathrm{O}_{5}$ を分離し, 之をサプ ロゲニンと命名せり。此物質は紫外線に依りて强き䖝光を發すといふ。高 橋偵造, 鈴木彰兩氏(䢅化 8, 1064)は火落菌並に火落性:乳酸菌の研究を續 行し, 数の種類と火落菌繁殖との關係及び柑椅類の汁掖と火落菌繁殖との 關係を探求し, 固有の火落菌は一般に整浸出液に繁殖不可能冷るも数菌の 種類を適當に選べげ必ボしも不可能ならざること及び相桶類及び其他の果 實, 野荣等の中には清酒に添加して著しく火落菌の繁殖を助成するものあ るを認めたり。

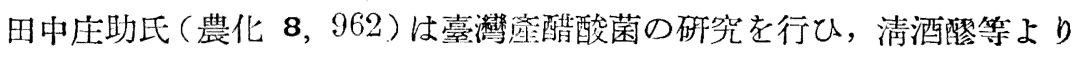
5 種の醋酸菌を分離し, 其の形態的並儿生理學的研究をなし, 速醋工業並 に食醋工業に應用し得べきるのあるを認めたり。

麥酒 駒澤利雄氏(酸造 10，191，278）は麥酒及麥芽に關する研究をな

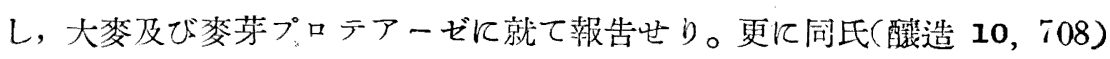

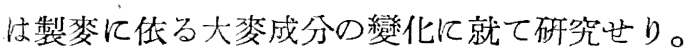

清酒 小穴富司雄氏(酸試報 114，398) はオジン應用清酒代用飲料製造 試驗を行ひ, 各種有機酸類, アミノ酸類を酒精に加ーオゾンを通ボるとと に依り清酒に類似したる風味を得られ，之に他の調味料を添加すれば清酒 代用品上なる旨報告せり。杉山晋溯, 勝目英, 高岸勝一郎氏等(醋試郝 114 , 84）は速酸配に於ける乳酸の一部をグルコン酸にて置挨するてとに依り酒 質を改良し得る旨報告世り。金井春吉, 小穴富司雄, 有松喜一氏等（酸試

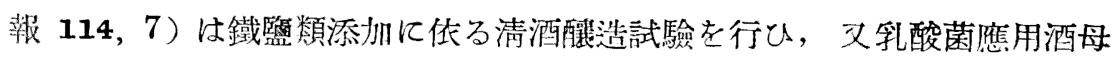
使用試驗をる行ひたり。 
佐治恒二氏（䝀造 10,983）以清酒中の果糖の定量法老研究し, 山田正

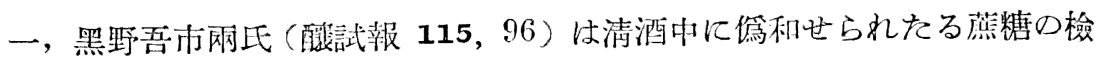

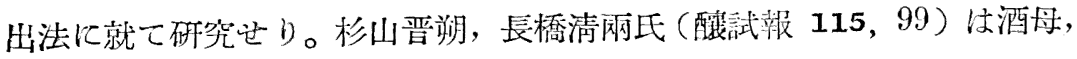
䌘, 淸酒及び合成酒中の空素物に就て研究せり。富安行雄氏(農化 8,905)

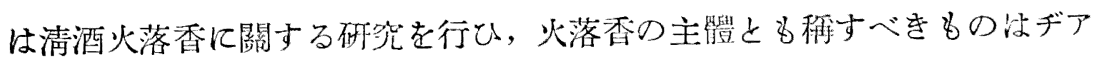
ヒチルなることを主張ぜり。

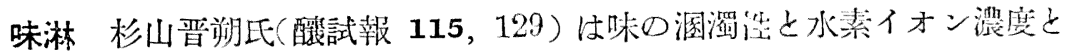

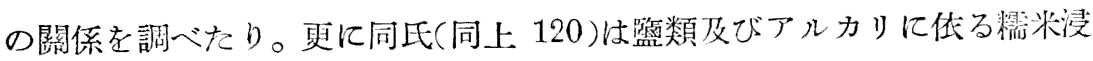
漬の試驗を行へり。

老紅酒 佐藤喜吉, 冈藤翇兩氏(釀造 10,719)は老紅酒の溷濁に關係士

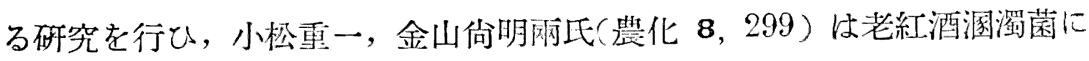
就て研究を行ひたり。

酒精及蒸溜酒 中村靜氏 (釀造 10,274, 343，519，806，911，993) は 酒精製造に就て廣沉なる㸴究をなし，先づ酒精製造原料としてての滿洲座 高粱に就て研究し, 高粱油中の不鹼化物を呼究し, 次で甘諸の酒精醗酵及 び飲料酒精の蒸溜に關する研㚾をなし, 主として酒精の蒸溜問題に就て詳 細なる報告をなせり。熊本伸一郎氏(日化 53，30) はフーゼル油の㸴究を 行ひ, 高粱フーゼル油よりアルコール類, 酸類, 鹽基類, フルフロル，エ

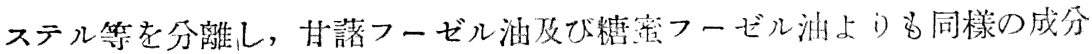
を分離せり。

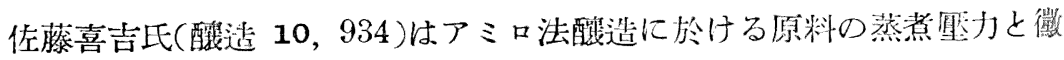
の繁殖と糖化作用との關係に就て䃏究し, 神谷俊一氏(䝀造 10,693)はつ ミロ法に依る米酒の製造に就て研究せり。武田義人, 岡田葷勝兩氏（農化

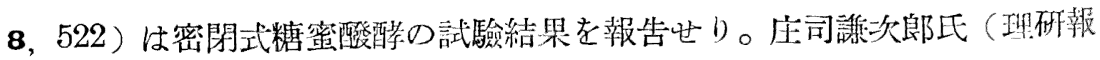
11，1353)は粕取燒酎》香氣に關する研究を行ひ，アセトアルデヒドフル 
フラール，ヂアセチル等諸種の物質を報告し，就中ヴェレリアン酸メチル・ アミル・エスラルは粕取燒酎の主要香氣成分なりと主張せり。

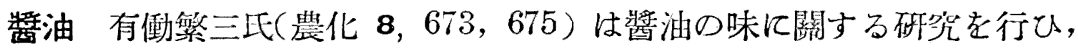

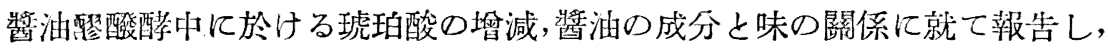
有機酸の解踓度と醬油の水素イオン瀑度との關係が其の味に重大關係する

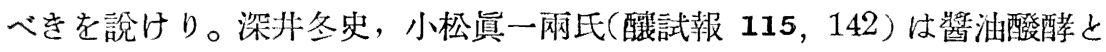

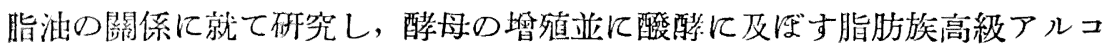
一ル類の影響を檢せり。更に深井冬史, 長橋清, 小松黄一氏等( 醇試報 115

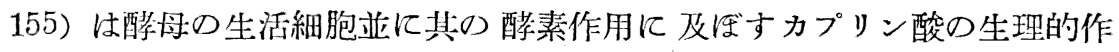
用飞就て研究世り。水下淺吉, 中岛和作兩世(醕試報 114, 445) 驻脱脂大 豆(櫻豆)の使用試驗を行ひたり。

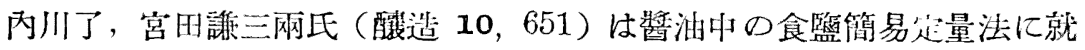
て研究し, 醬油に 5 10\% の活性炭素を加一約 5 時間作用せしめて脫色 し，滤過して 10２２倍に稀濢しクロム酸加里硝酸銀法に依りて定量する 方法を提案し，郡川敬次郎氏(同_上６51)は之に對する批判をなせり。庄司 啸次郎, 小貫基兩氏（理研報 11，277）はポーラログラフに依る醬油香氣 の研究をなし該香氣成分は還元壓曲線を現はさず，從つてソャナルの如き アルデヒドには非ずと推定せり。

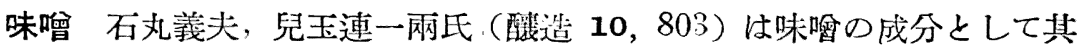
の油脂に就て研究世り。又管井芳人氏(農化 8, 1312) \&味畨の油脂に就て 研究したり。鈴木恒也氏（醋造 10，536）は味唓酸造中に於ける含空素物

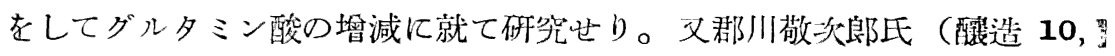
543）も市販味㿞中のグルタミン酸を研究したり。

特殊酸酸工業 高橋偵造, 朝井勇宣兩氏 (農化 8,703, 1180)はグルコ ン酸酸醋の研究圭續け Bacterium Hoshigaki var. glucuronicum II 及 
III 等に就て記载せり。坂口謹一郎氏(農化 8, 172, 489) は綵狀菌類て 依る枸格酸の製造に就て 硼笕し, 其の適當なる絲狀菌（Penicillium 及

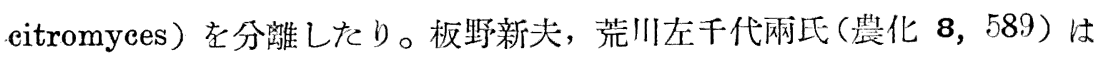
土壤中に於ける繊維素分解に關する硎究を續け, 主要なる好载性瀻維素分 解細菌の檢定をなせり。

六所交三氏（農化 8,734，799，931，1029）はアセトン・ブチルアルコ

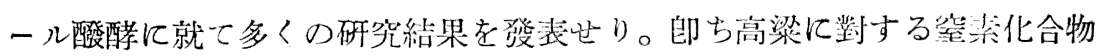
の影響, タンニン筫の影響等に就て研笁せるものなり。土屋程氏（農化 $\mathbf{8}$, 1209，1267）も亦ブタノールアセトン醱醭に就て研究し, 蛋白質添㞦の影 響を調へ,糖蜜は原料として不適當なるととを指摘せり。何ブタノール・ア セトン醱酵の研究として岡田穗積氏 (北海工試 38，1) の研究あり。 同氏は B. butyloacetonicus 及び生成物等に就て記载桨り。

\section{2. 製 革及膠類}

鞣皮法の改良, 擬革製造法, 海魚皮の處理法, 過多脂肪質魚皮の處理法 等に關する本邦特許は枚擧に遑無しと雖, 研究論文又は跨究報告として, 特に注目す可きもの無をを遺憾とす。

\section{3. 寫眞}

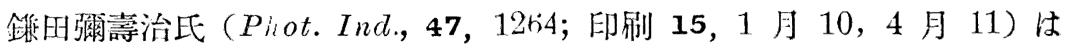
ハー七ル效果に就て研究し, 赤色光及橙色光のみ卉らす赤外線, 恵色光, 綠色光及び或程度まで靑色光にても其の效果を起すてとを知り, ハーセル 效果とソーラーリゼーションの現隹とを利用して適當の撮影法をなすをを

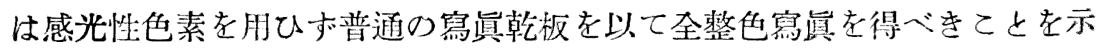
せり。 
贸井季雄氏(理研報 11，681)は種心の感光性色素に就き吸收スペクトル の测定並にてれ等色素の溶液に浸漬して感光促進性を賦與したる寫真乾板 に就き，夫ミ感光極大及び感光極限の测定を行ひ，感光性色素の化學構造 と光線吸收及び感光極大との關係に論及吖り。同氏(理研報 11，711)はま たヂアミド，ヂフ $ニ$ ル類のテトラゾ化合物並にデアミド，ヂフ アミン類のヂアゾ化合物等感光性を有する種々なる有機化合物の合成研究 を行ひ，ヂアミド,デェフニールアミン及び其誘導唓より印畫紙に適する感 光劑を製浩せり。同氏(理研報 11，1044）以更揳及び色滤光器を作りて 色感光を侍する寫訔乾板の色感光测定法老改良し之により種々の感光性 色素を以て處理せる乾板の色感光を测定せる結果に就き無色光線を 1 とし たる場合の他の色感光を数字的に表示せり。

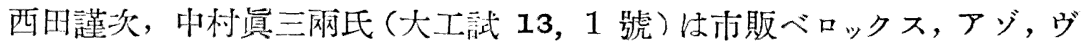

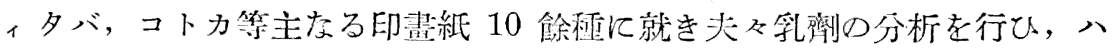
ロゲン銀の種類及量, 可溶性ハロゲン監の含有量の測定, 乳劑の水洗の有

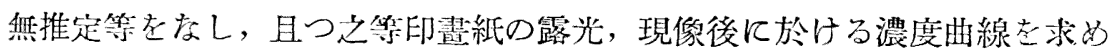
たり。

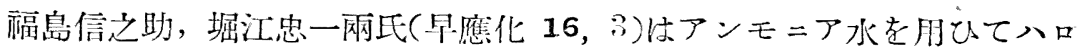
ゲン銀を抽出し，隨件する少量のゼラチン其他の有機物を除去したる後監

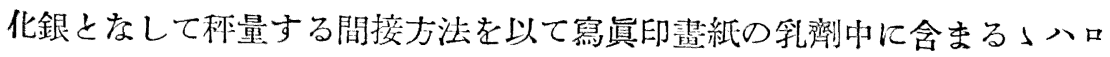
ゲン銀の定量法を研究し，オリエンタル會社及びイーストマン會社製の市 貶印畫紙 10 種飞就きハロゲン銀の定量及び臭化銀コロヂオン乳劑の感光 度を 1 とせる比感光度を测定せり。

西山善次氏（金屬 9,11 號 476) はデバイ。セーラーX線寫真の補正 に就て研究せり,殊に試料の大さに就ては鐵及アルミニウムを材料となし， 種々直徑の異なる試料の X線寫県を撮り之によりで利々の補正式に就き 
批判を加へ金屬の如く吸收度大なるものに對して䔈驗值に最も近き補正式 を羊せり。

中摆亮治, 武田義人, 末松勝利氏等(壹督研工㭉 65, 1 月; 農化 8, 1 ) は䓨灣に於て光學器具類の保䏡中, レンズの表面に繁殖する微の種類及び 防徽に關する研究を行へり。

\section{4. 爆發物及マッチ}

本部門中の主體たる火藥類の研究は陸海軍の電機祕密に屬するもの多 く，從つて公表せられたる報文比較的少し。

無煙火薬 の燃燒に關する山家信次, 增田信雄兩氏の研究（火兵 26, 13，21）は, 火藥の然燒函數 $\varphi(z)=s / s_{0}$ を從來の省略式に低らずして理 論的に幾何學的解析を行ひ，合理的なる實用涵數を決定せるものなり。而 して带狀, 紐狀, 管狀, 球狀及立方形, 並に七孔圓筒形の各藥形に就て詳 論ぜり。

爆蓕類 摩擦感度 試驗器の研究 は山田正幸比 (火兵 25,379) の行ふ所

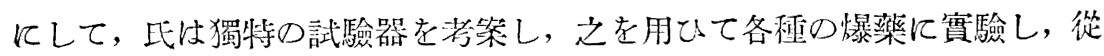
來不確なりし摩擦感度を克く數字的に確認するととを得たり。栗田茂策， 加納元市网氏（火兵 $25 ， 467$ ) は市販並に試製の工菜爆萫について猛度試

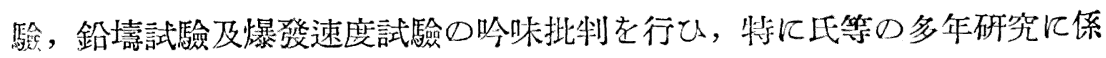
る所の不凍ダイナマイト類の性能を朋かにせり。

雷 管 宇治田景造, 小松勝光网氏 (火兵 26, 118) は雷永の裝填比重 （2.5）及䒚量 $(2 g)$ t一定にし, 雷管管豐の中徑と藥長との比を變化せし め，之に件ふ雷管の威力及起爆力の優少を比滧せり。

綿藥 千藤三下造氏(纎工 8，210）は 40 年來部分的にのみ研究せられ たる混酸組成によつて影響さる〉綿燕の諸监質を根本的に總括的研究を行 


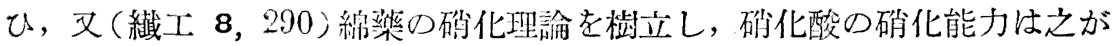
有する遊離エネルギールよつて测り得べきとを論證せり。富永孝三比(緎

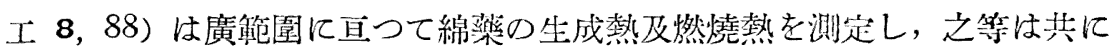

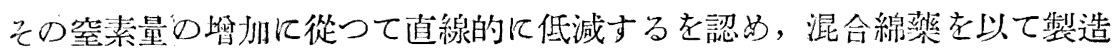
世る火藥と其の窒素量に相賞する中間硝化物を以てするるのとは，その熱 エネルギーに於て大差なきを推定せり。

電氣發火器 久村程樹, 能登久兩氏 (火兵 26,49 ) 以手働式電氣發火 器在改良して, その出力を大にし, 不發を防ざ, 而子普通の電氯雷管或は 電秋火管( 約 $0.6 \Omega$ の抵抗を有し約 $1 \mathrm{~A}$ の電流几て發火するもの) 500 發 以上の齊發を可能㐋らしめをり。

\section{5. 食品}

食品成分 食品成分に關与万研究として炭水化会物に就て次の如を研究 あり。四所哲太郎, 小林秀六, 不村克二氏等(農化 8，868，944) 㥓王縣

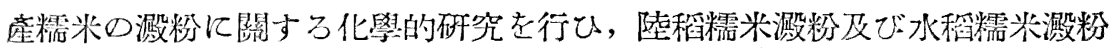
飞就て貑告する處ありたり。又西村資治氏(農化 8，400) はアミロースと アミロペクチンに就て研究し，アミロースもアミロペクチンも共に棼芽ア ミラーゼに依る喏化には著しき難易を認为難く, 䌅化の經過も略心相等し きものなりと主張吃り。岩田久敬比（農化 8，1175，1252）はペントザン

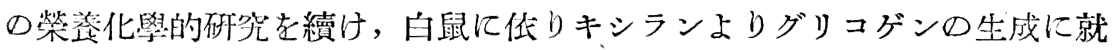

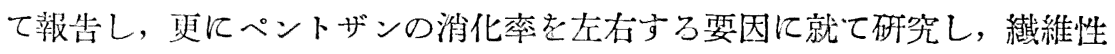

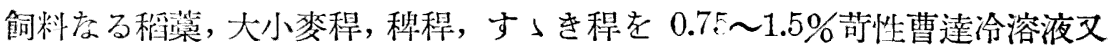
は 1\% 石灰乳 (冾熱共に) にて處理すれば其のペントザン消化率は 1.4〜 2.1 倍に增加するる， $0.25 \%$ 苛性曹遵冷溶液, 草木灰浸出液又は熱湯にて 處理する必其の消化率は塤加せざるてとを認めたり。 


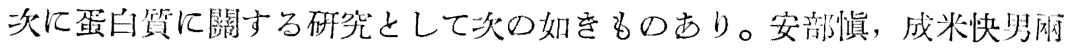
氏（農化 8，236）は性の蛋白質の化學的㸴究を續け，甲爿腺蛋白質の化學 的性質を調べたり。近藤金助氏 $($ 日化 53,880) は蛋白筫の溶解現象に就て 研究せり。又近藤金助，山田孝雄网氏（日化 53，898，945）溶液內に於 ける蛋白質の行䉆に就て研究し, 更に近藤金助, 富山新一网氏(日化 53,

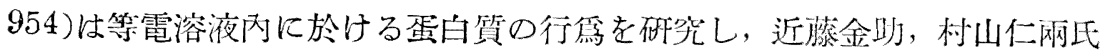
（日化 53，1108）はグリアヂンの對電行聕と濃度律に就て研笲せり。赤堀 四郎, 沼野信治, 金子武夫氏等日化 53，200，20 其の誘導體に關する研究をなし $\alpha$ アミノ酸よりイミダジール誘導䞍の合 成に關して郝告せり。高山義太郎氏(日化 53，1197) はチロシン及フェニル アラ =ンの電解酸化に就て泼告し, 高山義太郎, 大枝春臣网氏 (日化 53, 1205) は $\beta$ イイミ゙ジリルプロピオン酸の電解酸化汇就て報告せり。 䏌其他食品成分に關して次の如き研究すり。仵橋佳一氏（理研報 11, 1072) は白米中のェーテル可溶物の生理作用に就て研究を續け, 高度不怉

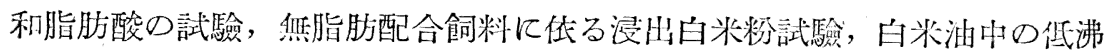

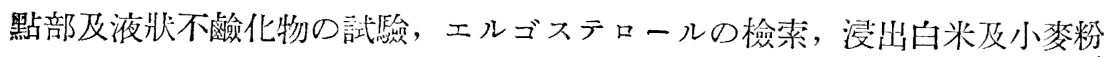
長期比較試驗等飞就て献告せり。小竹焎二雄, 松原多摩喜, 木本賴三郎, 田口勝太，阿部滋弘氏等は配糖體の化學的硎究を行ひたり（份油脂に關す る研究は別項を参照されたし!。

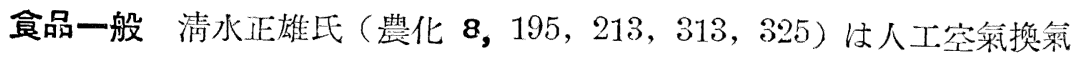

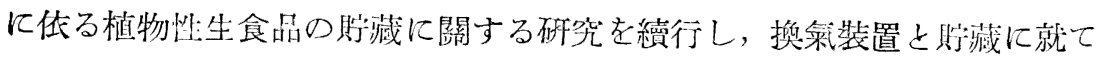
報告し, 更に生茶集の貯藏に就て人工空氣換氣法に依り品質低下を防止し 得らるってと並に葉菻類も此の方法に低り相當期間綠色の儘保倞しし得る

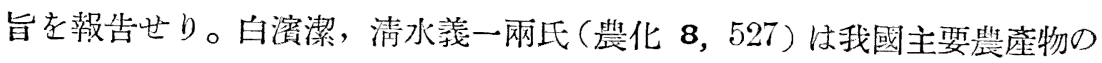

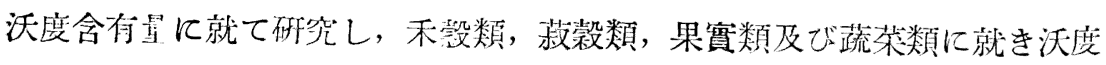




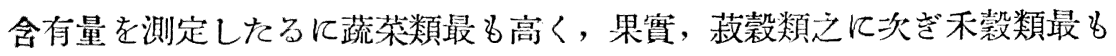
低をととを認め, 我國崖のものは歐米のものと此較する時沃度含有量遥加 に大なるものありと報告せり。

大豆 佐及木周都氏 (農化 8,417) は大豆の有機盬基類に就て研究し, アデニン,グアニン, ヒスチヂン, アルギニン, コリン,トリゴネリン等

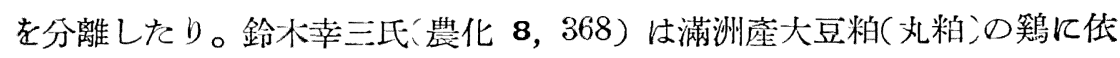
る消化率を研究し, 有機物 $67.0 \%$, 粗蛋白質 $84.8 \%$, 粗脂肪 $91.8 \%$, 粗纎 維 $2.2 \%$, 可溶無空物 $40.7 \%$, 純蛋白質 90.7 の消化率を得たり。少同氏 は高粱の消化率を調へ䉆飞就て $22.4 \%$ の蛋白消化率を得て高梁の蛋白質

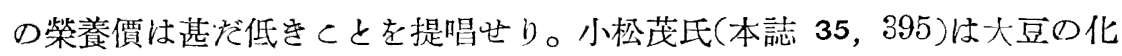
學に就て論議せり。又佐藤正典氏(本誌 35, 1319) は大豆工業の趨勢に就 て論じたり。鹿園直治, 友田冝孝兩氏(本誌 35，892)は大豆粕加水分解物 と醬油との比較研究を行ひたり。

大根 高橋梯藏比(㖘化 8, 393) は大根の炭水化合物几就て研究し, 吉村 清向, 惠藤唯實, 岩田武志氏等(農化 8, 1060) 櫻島大根の含窒素化合物 の研究を行ひたり。

馬鈴薯 吉村清向, 岩田武志爾上 (日化 53，1030) は馬鈴薯の有機監基 特にカダベリンの存在に就て研究し, アデニン, ヒスチヂン,アルギニン, トリゴネリン，カダペリン，コリン等を分離せり。

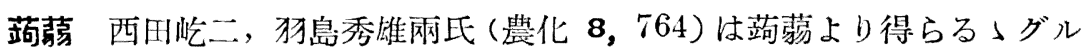
コマンナンの化學的研究を續行しグルコマンナンの構造式に就て論ぜり。 田所哲太郎, 安部慎, 吉村克二氏等 (日化 53,817, 1184) は站芴塊蔡の 生物化學的研究を行ひ, 站芴マンナンの性質及び蒟芴塊炭水化合物の代謝 飞就て報告せり。

寒天 高橋榮治, 白演潔兩氏（農化 8,659, 1259）は寒天の研究を續 
行せり。

果實 山本亮，川上行藏兩氏(農化 8, 391) はマンゴウ果望のカロチン に就て研究せり。藤井與次氏(䝀造 10，.61冲廢物利用として蜜相酒製造 法に就て研究し, 腐敗蜜柑, 屚蜜柑は蜜相酒製造に工業化し得万見込あり とせり。

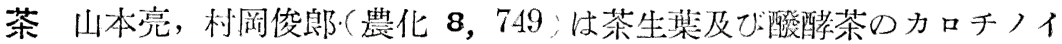
ドに就て研究せり。

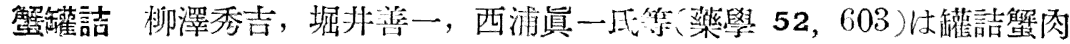
より生成するフォルマリンに就て研笁し, ヒスチデンよりフォルマリンを生 成するbのと結論せり。波多腰やす氏(日化 53，1026)はズワイガ=罐詰 肉つ成分に就て研究し, 肉は殆ど全く蛋白質なることが淡味なる所以にし て，又アルギニン，リジン，シスチン，ヒスチヂンに富みカゼインに比し て榮養上優れたることを指摘せり。近藤金助,岩前博网氏(日化 53，1013) はタラバガニ罐詰の蛋白質に就て研究し，ヒスチヂン及リジンに富み榮苓 上優良なるてとを明がせり。

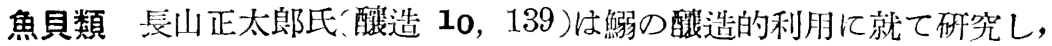

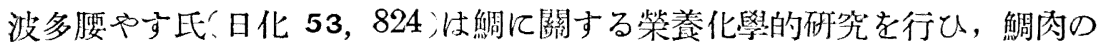
部位による成分の相違を調心，食味優越せる部分は脂肪多しとなせり。靑 木克氏 (農化 8,867) は貝類中に琥珀酸の存在に就て研究し, ホ夕テ貝の 具柱, 蛤, 蜆等特に旨味に富めるものよりは生肉の $0.1 〜 0.4 \% に$ 達する 琥珀酸を分離したり。

乳汁及乳製品 近藤金助, 森茂樹网氏 (日化 53，1163) は山羊乳の無機 成分に就て研究し, 又兩氏 (日化 53,1190) は乳汁中の鐵, 銅, 及び亞鉛の 含有量に就て研究し，幼兒又は病弱者に對しては乳汁中の鐵含有量過少に して，銅も鐵の造向作对を助くるには過少存るを以て鐵及銅に富的る綠集 
荣類を添加するの利益を指摘せり。又乳汁中の亞鉛の量が相當多量をるは 榮養學的燱義するものならんとせり。

鈴木梅太郎, 尾崎準一, 平尾营雄, 斎藤良一氏等(農化 8, 411) 以内外 產粉乳並にパトローグンに就て續報し，パトローダンの改良としてヴ，タ ミン D を新に加へたり。其の方法はバトローダン組成中の酔母の $1 / 3$ を 豫め 10 分䦭紫外線に照射して添扠するものにして此の場合ヴィタミンB

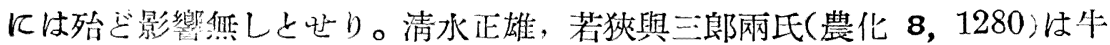
乳中の萑糖檢出端に比色定量にフロ、グルシンの應用に就て研垐せり。近 藤金助氏 (日化 53，1150) は加煻煉乳中の乳糖, 莏糖及び轉化糖を定量す る方法老研究せり。里正義, 村由喜一兩比(整化 8, 1303)は乳汁內の微量 アルコールの新定量法を考案せり。

ヴィタミン川上行藏氏(農化 8，48，55，64；理研報 11，968)はヴィタ ミンA に關する研究を行ひ，カロチノイドの紫外線に於ける吸收スペク トルを調ベ，ヒドロカロチンの性狀及び其生理作用を檢し，更にヒドロカ ロチノイドとビオステリンの關係を探求し, 本邦産各種魯類肝油の肝油單 位㳊就て追究せり。上野誠一, 太田均夫, 刀根幸太郎, 横山茂氏等 (本誌 35，1233) はヴィタミンAの 1 試驗法として養鯉試驗を行へり。小林久 平, 山本研一, 阿部二郎氏等(本誌 35,70 ) は棕櫊油のカロチン飞對する 酸性白土の呈色反應を研究し, ヴィタミン A 亿對する呈色反應と同一なる ことを認めたり。高田亮本氏(賈造 10，30，355，689）は醬油, 味唡, ソ 一ス等のヴィタミン $B_{1}$ 亿就て研究し, 大豆の浸漬, 蒸煮に依り著しくヴ ィタミン $\mathrm{B}_{1}$ を損失するてとを明か炕せり。松椆富治氏（農化 8，72）は ヴィタミンC K關する研究を續行し, 稞賽の發芽よヴィタミン C の關係を

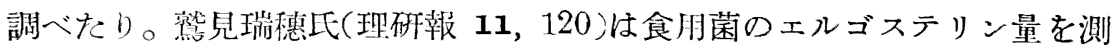
定し, 椎苹江限ら尔松苹, 初茸, しめじ, シャンピニオン, 松露, 橎菌胞 子, 乾燥酵母等にも椎苜に劣らず著明量のエルゴステリンを含むことを明 
かにせり。

榮養に關する研究 助川浩, 茶珍俊夫兩氏(醇造 10,837, 939) は工場 食の榮養調查報告をなせり。下田吉人氏（醙造 10，202，299）は學童辨 當に關する調査をなし，其の食量不足なるを以て辨當箱の大さを改むべき ことを主張せり。又下田吉人, 前川勇网氏(皽造 10,628,634) は食品の 榮養學研究を開始し, 土當歸, 及び隼人瓜に就て報告せり。

前田司郎氏（理研報 11，585，1098）は蛋白質分解物を以て蛋白質に代 用せる動物試驗の結県を報告し, 蛋白質は酵素に依つて分解するも其の榮 養價を失はボ，蛋白質硫酸分解物にはトリプトファンを加ふるのみにて完 全に蛋白質の代用となり得るととを認めたり。

尾崎準一氏（農化 8，1286）は脂肪の榮食價に就て研究を繼續し, 遊離 脂肪酸は多くのものは策養價無く, 石簽も榮養價大ならず, メチルアルコ 一ル山合成品ならば相當の策養價を有すること等を認めたり。份鈴木梅太 郎氏 (本誌 35，1342）は榮養化學と滿洲の產業に就て論ずる處すりたり。

\section{I 業 分 析}

一般定性分析 永海佐一郎, 加藤多喜雄 兩氏（東工學報 1, 1 號）は 普通元素及稀有元素 62 種につを, 此等の任意の化合又は混合狀態に於て 一元素 $0.1 \mathrm{mg}$ が他の任意元素の總量 $200 \mathrm{mg}$ と共存するにてる確實に檢 出し得べき方法を發表せられたり。高木誠司氏（燕學 52，3號）は Vortmann 等の硫化ソーダ法に依る普通金屬の定性分析法を改善し，且つ 一層適確ならしめたる方法を發表せられ穴り。同氏は文該雜誌に通常の定 性分析にて取扱ふ簛圍內の酸の類屬に對し稍組織化したる定性分析法を發 表せられたり。

アマルガムの應用 田代岉氏(日化 53，1)は容量分析にアマルガムを應 用する方法の第 15 報として沃素酸法による容量分析をアマルガム法に應 用し, 鐵及ウランの定量を試み，アマルガム法を應用してモリブデン,ヴっ 
ナヂン, チタン, 鐵及ウランの沃素酸滴定を行ひ, 此等金屬と沃素酸との 反應を確定せられたり。李叐化氏（日化 53，1）は容量分析にアマルガム を應用する方法の第 16 報として科量ビュレット中に於て液狀アマルガム にて四價のチタンを三價に還元し，之を標準液よして科量法によりて容量 分析を行はんと企てアマルガム法と科量ビュレット法とを組合せたる新容量 分析法を考案してチタンの還元容量分析法の缺點を除き, 連續的に滴定を 行ひ得べき方法及之を應用して鐵, 過酸化水素, メチレンブリュ一及銅を 滴定し得べきてとを發表せら礼たり。田代岉氏(日化 53，1)は容量分析に アマルガムを應用する方法の第 17 報としてアマルガム法を沃素酸滴定に 應用する際アマルガムの種類及還元條件を變更すれば或金屬は還元せらる る程度を異にする場合ある性質を利用して 2 金屬の混合溶液の示差滴定を 試み，亞鉛アマルガムと蒼鉛アマルガムとの還元力の差を利用し金屬を異 なる階級まで還元し沃素酸法による示差滴定をなし，鐵よチタン，チタン とウラン，鐵とヴっナヂンとの混合溶液を定量せり。金子清治,根本忠次郎 兩氏(本誌 35，5) は固狀のカドミウム・アマルガムを容量分析に應用する 新容量分析法を考案し之を鐵及モリブデンの分析に應用する方法を發表せ、 られたり。金子清治，根本忠次郎兩氏（本誌 35，7）は檋に中園氏の創始 せられたる方法を多少改善して其操作を簡單ならしめて鐵, ヴ、ナヂン， モリブデンの分析に應用し其操作を鐵, 明攀の分析に就て示されたり。

無機化合物其他 永海佐一郎, 田代岉兩氏 (日化 53, 12) はナトリウム の容量分析法に就て研究せられナトリウムをウラン及マグネシウムの三重 醋酸監として沈澱せしめ, 此沈澱を稀硫酸に溶解しカドミウムアマルガム を用ひてウランを四價に還元して過マンガン酸加里の標準液にて滴定して 再び六價に酸化し，其滴定數よりウラン引いてはナトリウムを定量する方 法を發表せられたり。石丸三郎氏(日化 53，10) は鐵と共存するアルミニ ウムの直接定量法に關する諸方法の得失を比較考察したる結果チオ硫酸子 


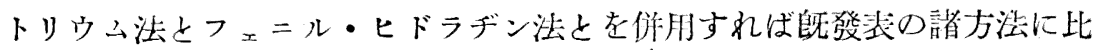
し一層簡單にして一屈正確なる资量法となることを發表せられたり。船橋 音藏过(日化 53，5)は亞セレン酸に上る答鉛の分析法に就て研究し蒼鉛を 亞セレン酸鹽として定量するとき之を $\mathrm{Bi}_{2}\left(\mathrm{SeO}_{3}\right)$ : として科量するより 强く灼熱して $\mathrm{Bi}_{2} \mathrm{O}_{3}$ に變じて科量する 方が正確にして且つ一分せる結果 を得へきてと發表せられたり。太秦康光, 三宅泰雄网氏(日化 53，9)は 吸着指示藥による滴是に就て研究し, 其第 1 報としてアルコールの存在に 於てフルオレスセインを指示嬊とするハロゲン・イオンの滴是と題しハ口 ゲン・イオンを含倠する試料溶液にアルコールを加へて滴资を行ふ際滴定 完了點の銳敏度に變化あるべき不豫想しフルオレスセインを指示暞としメ チルアルコール义はェチルアルコールの你在に於てハロゲン・イオンの銀 游定を試みたる結果アルコールの存在に於てはハロゲン・イオンを亦溶液 中に於けるよりも一䚄銳敏且正確に定量し得べき事を知り,北結果及 2,3 の應用例を發表せられたり。石丸三郎氏（日化 53，566-573）は所謂オキ シン法に依る $\mathrm{Cu}, \mathrm{Mg}, \mathrm{Zn}, \mathrm{Cd}, \mathrm{Al}, \mathrm{Bi}, \mathrm{Fe}, \mathrm{Mn}, \mathrm{Ni}, \mathrm{Co}, \mathrm{Ti}, \mathrm{U}, \mathrm{Th}, \mathrm{Ca}$ , 及 $\mathrm{Pb}$ 定量に就て研究し, 熱天科老用ひ前記各金屬オキシン監の一般的 處理法中酸化物に變化せしむる場合及オキシン監の蓝にて乾燥して恒量な らしさる場合との各《に就き夫心適當なる溫度範圍を䇥められたり。斯波 之茂, 西腹鹿藏兩氏（東工試 27,（1）33-41）は鐵及コバルトの共你に於 てヂメチル・グリオキシムに低るニッケルの直接定量法に就て研究し, 鐵及 コバルトの共存するニッケル溶液に酒石酸を加へアムモニアにて中和し，

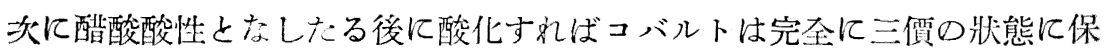
つを得べく，之にアムモニアを加へてアルカリ性となしヂメチルーグリオ キシムを加ふるときは完全にニッケル・ヂメチルーグリオキシムのみを沈澱 せしめ得てニッケルのみ在直接に定量し得べきてとを發表せられたり。下田

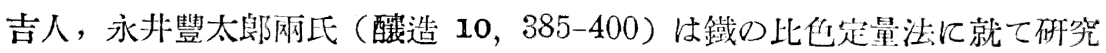


し，チオシアン酸鐵比色法!關しアセトン，チオシアン酸アムモニウム， 硝酸, 亞硫酸曹達, フォルマリン, 蒲萄糖, グリセリン, 乳酸, アルコー ル，エーテルが着色に及代す影響を調查し定量法として $50 \%$ 以上のアセ トンの使用を推獎せられをり。

定量スペクトル分析 岩村新氏(京理紀 A， 14，327-331，332-335)忖酸 化亞鉛中の $\mathrm{Cd}$ の定量, 發光スペクトル分析及鉛中の $\mathrm{Cu}$ 定量發光スペ クトル分析に就て研究し， Cd は $1.5 \times 10^{-4} \% ， \mathrm{Cu}$ は $3.5 \times 10^{-4} \%$ まで 檢出し得べき方法を發表ぜられたり。

微量分析 永海佐一郎, 田代物兩氏(日化 53,12) はカリウムを監化白 金酸加里 $\mathrm{K}_{2} \mathrm{PtCl}_{6}$ として沈澱せしめ，次に $\mathrm{K}_{2} \mathrm{PtCl}_{6}$ と沃化カリウム $\mathrm{KI}$ との反應によりて生ボる $\mathrm{K}_{2} \mathrm{PtI}_{6}$ 老チオ硫酸ナトリウムの標淮液にて滴定 する從來の方法を硎労しナトリウムと共存する微量のカリウムを容量分析 法によりて定量し且つ同樣の方法によりて微量のルビデウム，七シウム及 アムモニウム它定する量得をり。黑田チカ, 和田水兩氏（日化 53，2：は 簡單なる微量分析（主として炭素及水素の定量）に就てと題して燃燒管內 の酸化淮借成るを待ちて後初わて極綏徐江試料を燃燒して完全に酸化せし め生成したる炭酸瓦斯と水とを完全に吸收せしむることは普通の元素分析 と同樣なれぞも酸素を要ぜざるとと，試料の探取量の少きてと，其操作の 簡單なるとと等の特色を有する新分析法考考察し其賽驗裝置, 其配列法, 分析操作法等を詳細汇發表せられたり。艇山直人,牧白象二兩氏(本誌 35 , 900-906)は多量の銅及籃素イオンの你在に於ける銀の迅速微量定量法に就 て研究し, 從來殆に゙不可能と考へられたる銅及監素イオンの多量に存する 場合の銀の微量分析法に對し銀を全部 $\left(\mathrm{AgCl}_{2}\right)^{\prime}$ として溶存せしめたる㒒 $\mathrm{Cu}$ を $\mathrm{NaOH} に て \mathrm{Cu}(\mathrm{OH})$ : として除き其滤液を直ちにローダミンにて 着色して比色定量する方法を考案せられたり。

鐵及鋼 鐵及鋼硫黃分析方法, 工業品規格統一調查會は鐵及鋼中の硫黄 
分析法を制定し，日本標準規格第 108 號に之を發表せり。本分析法は (1) 炭素鋼，(2)銑鐵，(3) 特殊鋼，（4）合金鐵に區分世られ，炭素鋼は試料を 鹽酸に溶解し硫黃を硫化水素として發生せしめ, 之学醋酸亞鉛及醋酸カド ミウムの混合液に吸收せしめて硫化亞鉛及硫化カドミウムとなし，此等の 硫化物に規定ヨード溶液を少しく過剩に加へて之を溶解し, 規定于オ硫酸 ソーダ溶液にて過剩のョードを滴定して硫黃を定量し銑鐵及特殊鋼は試料 在硝酸及鹽素酸加里にて處理分解し, 更に鹽酸を加へて蒸發乾涸したる後, 水及廐酸にて溶解し之に亞鉛を加へて第二鐵を第一鐵に還元したる後, 監 化バリウム溶液を加へて硫酸バリウムを沈測せしめて硫黄を定量し，合金 鐵はフェロマンガン，フェロクロム， フェロシリコン， フェロヴァナヂウム， フェロタングステン， フェロモリブデン，フェロチタン， フェロフォスフォルに 區分して夫ぬ其定量法を制定せり。工業品規格統一調查會は鐵及鋼中の銅 分析方法を炭素鋼, 銑鐵, 特殊鋼, 合金鐵に區分して制定し日本標準規格 第 109 號に之を發表せり。

金屬及鑛石 石丸三郎氏（金屬 9，4-11 號）は金屬の定量に就て研 究し，合金中のアルミニウムの定量法を發表せり。田中清治氏（鐵鋼 18, 7 號) は鑄鐵の黑鉛組織に及ぼす瓦斯及熔解溫度の影響に就て研究し, 之 に附隨して極好徐冷されたる鑄鐵の如き大なる黑鉛片を含有する試料中 の全炭素分を定量する方法を發表せられたり。田如節郎, 安藤暹网氏（日 化 53，1）は錫石鑛分析法の一新法と題し，苛性アルカリ熔融に依りて錫 石を完全に可溶性に變じ得ざる理由を考察し, 次に其反應機構を明かにし をる錫石と石灰との接觸反應を分析に應用するため，木炭を觸媒として之 を大氣中にて行ふ操作を考へ，先づ密閉器中にて行ふには錫石 $1 \mathrm{~mol}$, 石灰 $7 \mathrm{~mol}$, 木炭 $0.05 \sim 0.5 \mathrm{~mol}$ の割合に密混し, 更に其密閉器內の空氣中の $\mathrm{O}_{z}$ を $\mathrm{CO}_{2}$ となすに充分をる量の木炭末を餘分に加 $900^{\circ} \mathrm{C}$ に 1 時間加熱 するを適當なりとし，更に操作を簡單ならしさるため㘫堝を使閔する場合 
$\sqrt{ } \mathrm{SnO}+7 \mathrm{CaO}+0.2 \mathrm{C}$ なる割合に圓筒形小磁製坩堝を取り其上を約 $2 \mathrm{~cm}$ の厚さの石灰層にて被ひ，此坩堝を底に本炭を入れたる大坩堝に入れ蓋を なし $900^{\circ} \mathrm{C}$ に 1 時間熱するを適當とするてとを明かにせり。鈴木廉三九 氏（岩石 8，129-131）は金鑛の鑑定, 金の檢出法に就き從來の濕式法を改 良し，何人にも容易に貫施し得へき方法を考案せられたり。原田隆康，伊 藤英一网氏 (水曜 6,831-835) は严鉛の定量分析並にアルミニウム中の亞 鉛の定量法に就て研究し, 黃血盬法を $\mathrm{Al}-\mathrm{Zn}$ 合金の定量に應用する場合 飞蟻酸又は构䋇酸溶液より $\mathrm{ZnS}$ の沈澱を作り燒きて有機酸を除き $\mathrm{HCl}$ に 溶解し $\mathrm{NH}_{4} \mathrm{OH}$ を加へて包含吸着のアルミニウム在除き 亞鉛を純粹に抽 出して定量する方法を發表せられたり。岡田左一郎氏(造幣 4，72-74）は 白色金 (ホワイトゴールド) の乾式試金法に就て研究し, 白色金の品位を 檢查するに Au 70, Ag 154, Cu 0-30, Ni 0-80, Zn 0-20mg の割合に配合 し, 之に約 $10 \mathrm{~g}$ の $\mathrm{Pb}$ 老加へ灰吹法にて分析するときは濕式法に比し正 確をる結果を得へく, 試料の探取量僅小にて足り, 且つ操作簡單なる利益 あることを發表せられたり。

瓦斯 筒口健十氏(旅工量 16 號)は鹽化パラヂウムに依る石炭瓦斯の檢出 法に就て研究し微量石炭瓦斯の檢出の外に炭坑內, 工場, 家庭及其他に於 て人體に有害なる一酸化岑素の微量檢出, 漏洩水素の檢出, 輕然料油炭化 水素蒸氣の檢出に應用し得べき方法を發表せり。グスタフ・ュンググレン 氏(特許公告 590 號) は一酸化岑素檢出用試驗紙の製造法に就て多孔質の 紙にパラヂウム鹽類及それより高濃度のアルカリ金屬の强監基と弱酸とよ り成る監類とを浸漬せしむるを特徵とする空氣中に健康上有害なる程度に 倞在する一酸化炭素を檢出し得べき試驗紙を發表せり。萩野秀壽，靑木昌 吉兩氏（國民徱生 9，1997-1408）は空氣中の炭酸瓦斯の定量法に就て從來 の测定法の缺點を呤味し, 此缺點を除き得べき新定量法を發表せらり。

電氣分析 斯波之茂, 西腹鹿藏兩氏(東工試 27，(1) 1-31) は純度の高 
きニッケルの地金を分析するときに起る置常析出超過に就て研究し,其超過

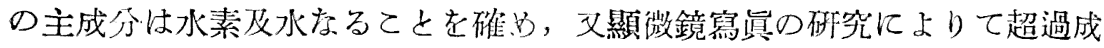
分包藏の狀態老示し, 次に其析出量と溫度との關係を研笁し, 溫度高き程 超過量の少きてとを確め，ニッケルの電解分析は $75^{\circ} \mathrm{C}$ 以上の溫度にて行 ふべきものなりと結論せられたり。射和三郎, 永井種太兩氏（マツダ 7 , 51-56）は各種水装イオン濃度に於けるヂメチルーグリオキシム圭沈溉劑と するニッケルの分析法に就て研究し $\mathrm{pH}$ 7.5-8.1 の範圍のときニッケル・ヂ メチルーグリオキシムの沈澱の生成完全なることを發表せられてり。正木康 作氏 Bull. C. S.J. 7. 188-200)はフェロシヤン化カリウム及ナトリウムの 電壓滴定に就て研究し，白金電極を指示極となし $\mathrm{HgCl}_{2}, \mathrm{NiSO}_{4}$ 及 $\mathrm{CoSO}_{4}$ 几就き實驗したる結果を報告せられたり。板野新夫氏(大原農研報 5，145150) は鹽素の電氣的定量法に就て研究し, 板野式改良携帶用水素イオン测 定器を Best 氏監素定量法に應用して終點明膫にして曲線圖を作る必要な く，着色又は溷濁せる試料を必滴定し得へくく，且つ個人的誤差考避け得べ き方法を發表ぜられたり。又、板野新夫，松浦章雨上（大原農研報 5, 171176) は前記の方法にて土壤中の監素老定量し，ク口ム酸監法(米國公定法) と比较して滿足なる結果を得べきてと，且つクロム酸籃法の數值と一致す るととを發表せられをり。炂井元太郎, 野四稻吉, 宮城精吉氏等(本誌 35 ,

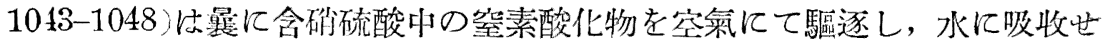
しめ電氣傳導度を测りて原液含硝度との關係を求好られたりしが，今回は 之をアムこニアを含有する籃類溶液の場合に應用し，更に原液が次第に變 化する㭶合にも連縞的に分析し得べを裝置を作られたり。

色素 立木勝藏, 見並淸一爾氏 (色染 3,353-359) は色素の分析几就て 研究し、來發表せられをる色素の分析法 5 種を概說し, 其內三監化チタン に依る還元分析法を G. Glübber 製巴素 10 種に適用したる實驗結果を報 告せられたり。 